\title{
Report of the
}

\section{6th NATIONAL CONFERENCE ON}

\section{WEIGHTS AND MEASURES 1961}

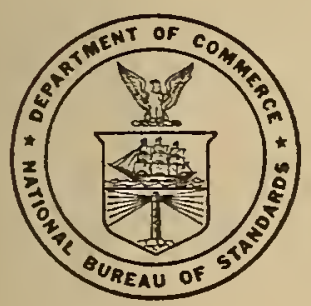

U.S. DEPARTMENT OF COMMERCE

NATIONAL BUREAU OF ST.A.NDARDS

MISCELLANEOUS PUBLICATION 239 


\section{SELECTED WEIGHTS AND MEASURES PUBLICATIONS OF THE NATIONAL BUREAU OF STANDARDS}

NBS HANDBook 44-2d Edition-1955 Specifications, Tolerances, and Regulations for Commercial Weighing and Measuring Devices:

Loose Leaf (does not include binder) $\$ 1.00$

NBS HANDBOoK 67 Checking Prepackaged Commodities .35

NBS Crrcutar 501 Federal and State Weights and Measures Laws

6. 50

NBS Circular 540 Weights and Measures Case Reference Book. 1.25

NBS Circular 547 Precision Laboratory Standards of Mass and Laboratory Weights .35

NBS Circular 593 The Federal Basis for Weights and Measures.

NBS Monograph 15 Calibration of line Standards of Length and Measuring Tapes at the National Bureau of Standards.NBS Miscellaneous Publication 233 Units of Weight and Measure-Definitions and Tables of Equivalents..........-

AVAILABLE REPORTS OF THE

NATIONAL CONFERENCE ON WEIGHTS AND MEASURES

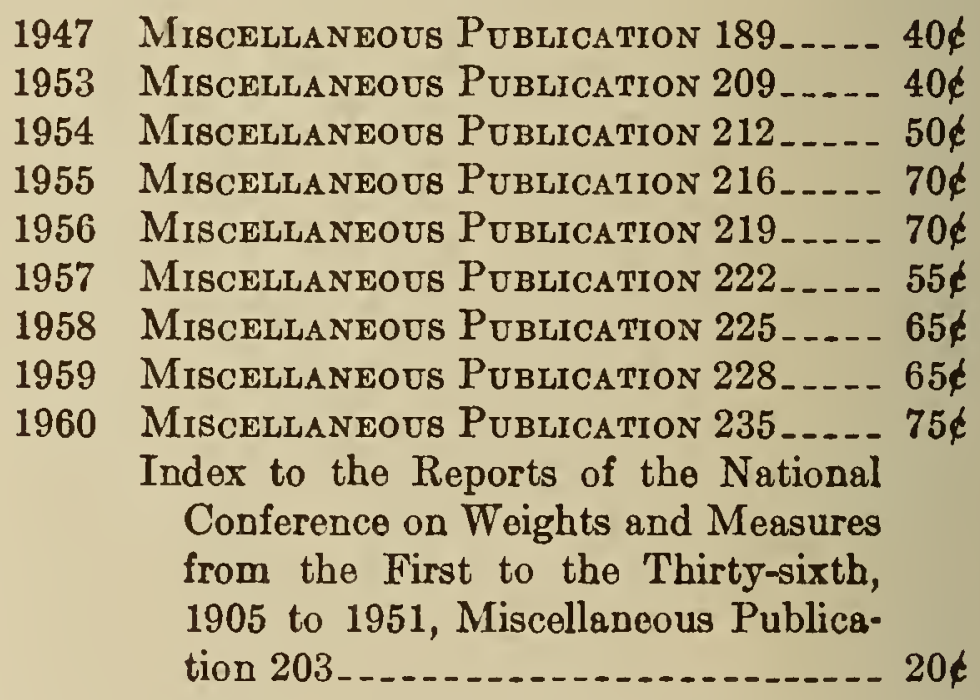

ORDER ALL PUBLICATIONS, WITH REMITTANCE, FROM THE SUPERINTENDENT OF DOCUMENTS, GOVERNMENT PRINTING OFFICE, WASHINGTON 25, D.C. 


\section{Report of the}

\section{6th National Conference on \\ Weights and Measures 1961}

Sponsored by the National Bureau of Standards

Attended by Officials From the Various

States, Counties, and Cities, and

Representatives From U.S. Government,

Industry, and Consumer Organizations.

Washington, D.C., June 12, 13, 14, 15, 16, 1961.

United States Department of Commerce

Luther H. Hodges, Secretary

National Bureau of Standards

A. V. Astin, Director

National Bureau of Standards Miscellaneous Publication 239

Issued January 18, 1962

For sale by the Superintendent of Documents, U.S. Government Printing Office

Washington 25, D.C. - Price 65 cents 


\section{OFFICERS AND COMMITTEES}

\section{OFFICERS}

(As elected by the Forty-fifth National Conference to serve during the Fortysixth National Conference)

President: A. V. Astin, Director, National Bureau of Standards.

Secretary: W. S. Busser, Chief, Office of Weights and Measures,
National Bureau of Standards.

Chairman: R. E. Meek, Director, Division of Weights and Measures, State Board of Health, State of Indiana.

Vice Chairmen:

J. W. D. Harver, State Oil Chemist, State Oil Laboratory, Department of Revenue, State of Georgia.

H. D. Robinson, Deputy State Sealer, Department of Agriculture, State of Maine.

A. D. Rose, County Sealer of Weights and Measures, Kern County, California.

J. D. Walton, Supervisor, Weights, Measures and Markets, Dallas, Texas. Treasurer: C. C. MIorgan, City Sealer of Weights and Measures, Gary, Indiana. Chaplain: R. W. Searues, Deputy County Sealer of Weights and Measures, Medina County, Ohio.

(As elected by the Forty-sixth National Conference to serve during the Fortyseventh National Conference)

$\left.\begin{array}{l}\text { President: A. V. Astix, Director, National Bureau of Standards. } \\ \text { Executive Secretary: W. S.IBusser, National Bureau of Standards. }\end{array}\right\}$ Ex officio

Chairman: Robert Willians, County Sealer of Weights and Measures, Nassau County, New York.

Vice Chairmen:

PaUl DeV $V^{\prime}$ res, Municipal Superintendent of 'Weights and Measures, Passaic, New Jersey.

H. H. Houstos, Director, Oil Inspection Department, State of Colorado.

F. F. Thompsos, Chief Chemist, Petroleum Products Tax Division, Department of Revenue, State of Louisiana.

D. M. Turn bult, Director, Division of Licenses and Standards, Seattle, Waslington.

Treasurer: C. C. Morgan, City Sealer of Weights and Measures, Gary, Indiana. Chaplain: R. W. Searbes, Deputy County Sealer of Weights and Measures, Medina County, Ohio.

EXECUTIVE COMMITTEE

(As elected by the Forty-sixth National Conference)
A. V. Astin
IV. S. Bussey
R. WiLLiaMS
P. DEVRIES
H. H. HOUSTON Ex officio
F. F. Thompson
D. MI. TURNBULL
C. C. Morgax
R. IV. Searles
II. H. Cramer, of New Jersey.
II. E. CRAWFord, of Jacksonville, Florida.
R. I. Cummings, of Altoona, Pennsylvania.
A. H. DitTrich, of New Iampshire.
G. L. Johnson, of Kentucky.
R. E. MEEK, of Indiana.
D. R. Pratt, of Sinta Clara County, California.
R. Rebuffo, of Nevada.
C. H. WrENN of Danville, Virginia.
R. Zierten, of Racine, Wisconsin. 


\section{STANDING COMMITTEES}

(As constituted at the conchusion of the Forty-sixth National Conference, the personnel and organization of each of the standing committees of the Conference are as listed. As reported, the membership of each eommittee reflects the appointments made by the President of the Conference to fill vaeaneies that hive occurred from expiration of term, and the elections by the several eommittees of chairmen for the ensuing year. The remaining term of office for each eommittee member, in years, is shown by the figure in parentheses following ench entry.)

\section{COMMITTEE ON EDUCATION*}

J. F. True, of Kansas, Chairman (2).

IV. A. KERLIN, of California (1).

J. E. Bowen, of Newton, Massaehusetts (3).

C. H. STENDER, of South Carolina (4).

J. T. DAwren, of Detroit, Miehigan (5).

\section{COMMITTEE ON LAWS AND REGULATIONS*}

J. H. LEwIS, of Washington, Chairman (4).

Robert Willians, of Nassau County, New York (1).

J. G. Gustafson, of Minneapolis, Minnesota (2).

H. M. Turreli, of Pennsylvania (3).

A. E. Diaz, of Puerto Rico (5).

\section{COMMITTEE ON SPECIFICATIONS AND TOLERANCES*}

C. L. JACKsox, of Wisconsin, Chairman (1).

R. W. Searles, of Medina County, Ohio (2).

A. H. Ditmrich, of New Hampshire (3).

T. C. HARRIS, JR., of Virginia (4).

H. J. MCDADE, of San Diego County, California (5).

W. S. Brssey, Executive Secretary of the Conference, is ex officio nonvoting secretary to each committee.

\section{COMMITEES ACTING ONLY DURING THE FORTY-SIXTH NATIONAL CONFERENCE}

Committee on Nominations: C. H. Stender, of South Carolina, Chairman; R. M. Bodenweiser, of Mercer County, New Jersey; H. N. Duff, of Colorado; H. E. Howard, of Miami, Florida; G. L. Johnson, of Kentucky; H. J. McDade, of San Diego County, Cahifornia; J. I. Moore, of North Carolina.

Committee on Resolutions: Raymond Rebuffo, of Nevada, Chairman; G. W. BAY, of Missouri; J. T. Daniell, of Detroit, Michigan; W. C. Hughes, of Massachusetts; W. H. Jennings, of the Distriet of Columbia; J. F. Madden, of New York; N. P. Tilleman, of Green Bay, Wiseonsin.

Committee on Auditing: C. W. VAN Scholk, of Ohio, Chairman; W. E. Czara, of Minnesota; W. I. Thompson, of Monmouth County, New Jersey.

\section{IN CHARGE OF LADIES' PROGRAM}

Mrs. W. S. Bussey, Mrs. M. W. Jensen, Mrs. H. F. Wollin.

\section{IN CHARGE OF REGISTRATION}

Mrs. F. C. Bell, Mrs. E. L. Brueckner, Mrs. M. M. Brodmerkel, Mrs. Clatre Patterson.

\section{PRESS REPRESENTATIVES}

J. F. Rerlly, Mrs. C. C. Atwood. 


\section{COMMITTEE MEETINGS, MONDAY, JUNE 12, AND TUESDAY MORNING, JUNE 13, 1961}

All day Monday and the morning of Tuesday were set aside for meetings, both open and executive, of the Conference committees. Announcements of these meetings were carried in the National Conference Announcement sent out April 1, 1961, and in the printed program.

A large number of delegates took advantage of the committee meetings and, as a result, attendance and participation were exceptionally good.

The Conference committees that met on Monday were the Committee on Laws and Regulations and the Committee on Specifications and Tolerances. The committees that met on Tuesday morning were the Executive Committee and the Committee on Education. 


\section{REPORT OF THE FORTY-SIXTH NATIONAL CONFER- ENCE ON WEIGHTS AND MEASURES ${ }^{1}$}

\section{FIRST SESSION-AFTERNOON OF TUESDAY, JUNE 13, 1961.}

(R. E. Meeis, Chatrifan, Presiding)

The invocation was delivered and the memorial service for departed members was conducted by the Conference Chaplain, Rev. R. IV. Searles, Deputy County Sealer of TVeights and Measures, Medina County, Ohio.

Mr. John P. McBride, Past Chairman of the Conference, led the delegates in the Pledge of Allegiance.

\section{ADDRESS BY HON. LUTHER H. HODGES, SECRETARY OF COMMERCE}

It is a great peasure to be with you today and be able to bid you rrelcome personally and on behalf of the Department of Commerce.

More than a half century ago the annual report of the Director of the National Bureau of Standards for the year 1905 contained the following sentence: "During the year, a meeting of State sealers of reights and measures was held at the Bureau." Eleven people came to Washington to participate in that meeting, and the Director's report noted that "the results of the meeting were eminently satisfactory."

From that modest beginning has come this annual Conference. The participants now number many, many times 11 . But I hope at the conclusion of this 46th National Conference on Weights and Measures you will feel that the results of your meeting have also been "eminently satisfactory."

This Conference and the National Bureau of Standards have grown up together. The Bureau was created in 1901 from the original Office of Standard Weights and Measures in the Treasury Department. Thus it was only 4 years old when it sponsored the first of these annual Conferences.

The Bureau set out from the beginning to help the States improve their weights and measures. Among its earliest research was work on meters for gas and electricity.

Today, we tend to take weights and measures for granted. The average citizen does not realize how heavily he depends upon measurement. He takes it for granted when he buys canned and packaged goods even as he checks the reight on the label to compare

I With the exception of formal papers and committee reports, the record of the 46 th National Conference on Weights and Measures has been rearranged, consolidated, con densed, and, in some cases, comments have been eliminated wherever necessary to reduce the printed report to essentials for future reference. 
prices. He takes it for granted that his butcher's scales are accurate and that he is getting the gallons of gasoline indicated by the number's on the pump.

We can afford to take these things for granted today because of the kind of job you and your predecessors have done at the State and local level. You have built, through education and diligent enforcement, the kind of atmosphere in which businessmen and their customers alike can assume that the things they buy and sell-and the things their business competitors buy and sell-are accurately weighed and measured according to universally accepted standards.

I commend you for the vital work you are doing, and doing so well.

Our job, in the Department of Commerce, is to promote and enconrage the growth of the Nation's business, trade and industry. We seek to accomplish this through our technical agencies, such as the National Bureau of Standards, the Weather Bureau, the Patent Office, and the Coast and Geodetic Survey; through our factfinding and information agencies, such as the Census Bureau and the Office of Business Economics; through our transportation agencies, the Maritime Administration and the Burean of Public Roads; and through the direct business promotion activities of the Bureau of Foreign Commerce and the Business and Defense Services Administration.

We have now added the new Area Redevelopment Administration to this array of business development agencies, and we expect soon to have an aggressive program to promote foreign travel to the United States.

The scope of the Department's activities is very broad-as broad as the connotations of the word "commerce," which range from a simple transaction in the comer grocery store to the complexities of an international trade agreement. Through the fabric of commerce there runs, however, a clearly identifiable thread-the need for equity in commercial transactions, for confidence between buyer and seller that where goods are exchanged for money there is a single, just balance for both buyer and seller.

This trust is the very foundation of commerce, and the atmosphere of confidence is made possible by the work you do-to assure, in the words of the motto of National Weights and Measures Week, "That equity may plevail."

Weights and measures are as old as recorded history. Yet the field is as dynamic as the newest fronticrs of science. New developments in science and technology move rapidly into the production and distribution of goods and services. New products, new techniques of packaging and distribution, more public and private buying of more sophisticated products, place greater responsibilities upon weights and measures officials.

The National Bureau of Standards' programs of scientific research provide the broad base for its technological competence. This competence enables the Bureau to help you in meeting the specialized technical problems of weights and measures.

The Bureau must continually refine the national standards of measurement. 'Temperatures as low as 459 degrees below zero Fahreuheit and as high as millions of degrees must be accurately meas- 
ured for scientific experiments. Length measurenents must be made with an accuracy of one-millionth of an inch for certain rocket components. 'Time interval measurements to one hmulred billionth of a second are needed for satellite tracking.

Increasingly more accurate measurements are necessary for our military and space program, for our economic progress, and for the adrincement of science itself.

A manufacturer in Califomia must know that his parts will fit with those of a manufacturer in Florida. A merchant in New England must know his products will be weighed against the same standards when they are sold in Alaska. In a similar manner, through our measurement system, scientists can be sure that the results of their experiments will be valid and meaningful to other scientists.

We intend to support a strong, dynamic program for the National Bureau of Standards. 'Tomorrow morning, it will be our pleasure to break the ground for the Bureau's new laboratories at Gaithersburg, Maryland. 'The chairman of your Conference, Mr. Meek, will be among the invited guests, and I am certain he will share our feeling that this ceremony will symbolize a significant step forward in meeting the measurement requirements of our country.

These new laboratories will cost more than 100 million. But the Burean of Standards should have the finest possible equipment and facilities if we are to be first on the moon and continue to be the leading technological nation on the surface of the earth.

The first of the new laboratories will permit long overdne development of accurate means of measuring forces up to 1 million pounds. The inability to measure precisely the thinsts of great rockets has been a major bottleneck in our rocket and space programs. And we have probably spent more than $\$ 100$ million to test rocket thrusts by the crude method of actually having to shoot expensive rockets into the air.

The Bureau of Standards has been lagging behind the rapidly adrancing demands of modern weaponry and industrial technology. The quality of its rork, mnder Dr. Astin's leadership, has continued to be above reproach, but it has lacked the financial silpport to enable it to meet the demands our economy and our national security have placed upon it.

Fortunately, there is growing appreciation of the importance of the Bureau's function in a rapidly changing, technological society. The new laboratories will be concrete evidence of this new appreciation and new support.

The National Bureau of Standards is the cornerstone mpon which a large number of important technical agencies and activities have been built in our Federal Government. There is incleasing need for greater coordination, communication, and planning in this vital area of technological development.

Only in the last few years has there been a central agency deroted to making available to the business and scientific communities the vast amount of scientific literature developed in federally supported research projects and in federally financed translation of foreign scientific publications. 
This function is now performed by the Office of Technical Services in the Department of Commerce. And already the Office has the country's largest collection of publicly available scientific and technical reports.

Recently our Office of Technical Services received a letter from a midrestern military command post asking for a copy of a technical report one of its scientists had read abont in a technical journal. Providing information to technical publications on the research reports available is, of course, part of the Office of Technical Services' task.

The revealing thing about this request was that the research report these military scientists wanted to see had been prepared by scientists at the same military base-morking on the other side of the post under a different military command.

We have asked the Congress to authorize a new Assistant Secretary of Commerce for Science and Technology to help us make the most intelligent use of Commerce's rarious techmical agencies, and to work with other Government agencies and private industry to achieve more fully the benefits that can be derived from an estimated $\$ 14$ billion now being spent annually for research and derelopment. Tre believe Congress will grant onr request.

The new Assistant Secretary would be a person of scientific and administrative competence who could concern himself to a greater degree than is now possible in the Department with the kind of job we are doing to help local and State officials carry out their duties in a highly technical society. He could provide leadership and long-range planning within the Department, and in the fulfillment of the Department's many technical responsibilities to business, industry, and local gorermments.

There is no important area of science and technology today which does not derive some measure of its support from activities within the Department of Commerce. It is important that the scientific and technical activities of the Department be represented by a professionally trained scientist-administrator at the highest levels of policy deliberation.

Science and technology will have increasingly greater impact upon our economy and our society in the years ahead. We want the splendid scientists and engineers of the Department of Commerce to be in the vanguard of these developments.

Science, measurement, and technology go hand in hand, and our future prosperity will depend upon how well we all work together to create the best standards, devise the best methods of making an ever-increasing number of measurements, and guarantee accuracy and equity wherever things are measured and weighed.

No job of measurement is too small to be important, and there is no more fundamental task than to help create and maintain the standards by which all men are willing to measure.

'Thank you for coming and taking part in this National Conference on WVeights and Measures. 


\section{By A. T. Astmx, Director, National Bureau of Standards}

I am very pleased to be with you again today. This meeting marks the tenth time I hare appeared before you as Conference Chaiman. Looking back over the 9 rears since I first had this opportumity, I an rery pleased with the progress that has been made in niatters of interest to the nember's and delegates to this Conference.

One of the most important achierements was the formalization for the first time of operating rules and procedures for the Conference, including the introduction of a new post, that of Conference Chairman, a position which is filled by election from the Conference. I believe this has been a rery important step forward in strengthening the Conference, and I am pleased to have been able to participate in bringing it about.

Another important step was the establishment of a Weights and Measures Adrisory Committee to the Office of the Director of the National Burean of Standards. The have found this advisory committee most helpful and your present Conference Chairman has been a very raluable member.

Probably the most important step taken by the NBS to improve its services to weights and measures officials is the introduction of specialized training courses for such officials. 'This activity appears to have been rery well received. It is one of the things that I hope to see strengthened and extended in the vears ahead.

The NBS publications have also continued to play an important role for the Conference itself and for the day-to-day work of the Conference members.

In the publication area I must report that Handbook 26 has not ret gone to press. I think I assured you last year that it would be in your hands by this time, but we lost the man that we were depending on to do the job. He went to Tokyo last simmer on a special assignment for the National Science Foundation, and the job has lapsed. I have recently developed, in consultation with our Office of Weights and Measures and, in turn, in discussions with your Conference Chairman, a procedure which I think will get this handbook moving, so that, if all goes well, you will have it at the tith National Conference.

It has always been my custom in my appearances before you to give a brief report on major occurrences during the preceding year inrolving NBS and of interest to the Conference delegates. Perhaps the most significant event since we met last year was the 11th General Conference on Weights and Measures held in Paris in October 1960. Present at this conference were delegates from approximately 30 of the 36 nations that adhere to the Treaty of the Meter. As you know, the Treaty of the Meter is the means by which the nations of the world cooperate to assure uniformity of measurement throughout the world and thus provide a common basis for the exchange of goods and scientific data.

This 11th Conference was, I believe, one of the most important in the series of such conferences that have taken place since the 
signing of the Treaty of the Meter in 1875. It is without question the most significant of these conferences to be held in this centnry.

Perhaps the outstanding single accomplishment of the 11th Conference was the redefinition of the meter. After many years of negotiation and research a new basis was formally adopted for defining our standard of length. This new definition in terms of a wavelength of light replaced the old definition which had been in existence since 1889. The old definition was based on the distance between two rulings on a bar of platinum-iridium, which was maintained in the vanlts of the International Bureau of Weights and Measures at Paris. Now, through mse of advanced interferometric techniques and our knowledge of the properties of atoms as determined by spectroscopic analysis of the light they emit, we have a more precise, a more durable, and a more universally available standard of length. Thus, the meter is now defined as 1,650,763.73 wavelengths of the orange-red radiation from the krypton 86 atom.

In the United States, as in the other English-speaking comntries, the common mnits of lengtl, such as the inch, foot, and mile, are based on the meter. Thus the action with respect to the meter means that the inch is now defined as $41,929.398742$ wavelengths of this particular radiation of krypton 86 .

This new definition made no significant change in the length of the inch. Actually we cannot say whether its length was changed or not. We can only say that it was not changed by more than one part in ten million since this is approximately the uncertainty with which we can make length measurements. Tie are certain that the new definition will make no difference in your operations. It is, however, of major importance to some branches of our advancing technology which will require ever-increasing accuracies for length measurement.

Another important achierement of the 11th General Conference on Weights and Measmes was the intiation of a program for international collaboration in the standardization of techniques for measnning ionizing radiations. 'lhese are the radiations associated with atomic energy development X-rays, and with the nse of radioactive isotopes in a rariety of scientific and industrial applications. Through this new program in the International Bureau, we shall have a means of assming that measmrements in this field will be properly compatible throughout the world.

Another achievement of this intenational meeting was a redefinition of the second-or rather a ratification of an earlier tentative definition of the second. The second had been defined as $1 / 86,400$ part of a mean solar day. Since the mean solar day is a somewhat indefinite quantity, and since the days are known to vary in length, it was necessary to provide a more stable basis for time measurement. So the second was formally defined in October of 1960 as a fraction of the tropical rear 1900 . 'The specific fraction is $1 / 31,556$,925.9747 , approximately $1 / 31$ millionth of the year.

The General Conference recognized that this definition of our unit of time was an interim one and urged the national laboratories to pursue their researches on new techniques in order to arrive at an atomic definition for time that would be analogous in some respects to the atomic definition for our unit of length. 
The General Conference also anthorized an increase in the anmmal operating budget for the International Bureau of Weights and Measures. This change was long overdue since the International Burean had been operating on in more or less static budget since the $1920^{\circ} \mathrm{s}$ in spite of the tremendous growth in its responsibilities for international coordination of measurements within the past few decades.

Important but minor compared with the things I have just mentioned were actions taken in improving the definition of temperature, and decisions on some of the terminology relative to weights and measures activities.

The Conference also made an attempt to revise the Treaty of the Meter. However, the attempt was msuccessful, largely because of political differences between some of the member nations, and so this needed action was deferred.

We were, however, successfui in accomplishing all of the technical or scientific objectives which lay before the Conference at its begimning.

Turning now to the National Bureau of Standards, I am pleased to report that we have made significant progress in many parts of our technical program, and in addition lave brought about a number of administrative improvements.

I shall mention only a few of the developments in our technical program. In our laboratories we are working to improve even further our ability to make accurate length measurements. Using radiations from mercury atoms, we have already devised methods pointing to an even better standard of length than the one that was adopted last October. Such a standard would have at least 10 times the accuracy of the krypton definition of the meter.

We have also been working very actively toward an atomic definition of time. Recently, at our laboratories in Boulder, Colorado, we achieved some of the most accurate measurements that have been made anywhere in the world on a potential time-interval and frequency standard. Some of our measurements there have been consistently reproducible to a part or two in one hundred billion.

We have also made substantial improvements in our ability to measure temperature throughout the entire range from near absolute zero up to many thousands of degrees. In this work we have been attempting to extend both the range over which we can measure temperature and the accuracy with which we can make measurements throughout the range.

Our sound laboratory has developed an electronic detection system for studying sound waves that are propagated through the atmosphere at frequencies too low for the human ear to perceive. These inaudible sounds, which we call infrasonic waves, are caused by earthquakes, tornadic storms, and geomagnetic disturbances. Our detection method promises to be of value not only in following the path of tornadic disturbances but also in learning more about the physics of the upper atmosphere.

In connection with the work of our Central Radio Propagation Laboratory in Boulder, we are now installing an elaborate observation facility in Peru, at an expected cost of about $\$ 1$ million. This installation will be on the magnetic equator and will thus give us a 
powerful new means of exploring the electrical characteristics of the earth's atmosphere.

Turning now to the administrative side of our program, I think one of the significant achievements was the formulation of a mission statement for the National Bureau of Standards. TVe believe this statement will provide focus for our work; it will help us to choose among various jobs we might do and to assign priorities to the jobs we have undertaken.

We consider that our mission at NBS is to provide national leadership in the development and utilization of uniform, accurate techniques for physical measurements.

This mission has three major parts. 'The first is to provide the central basis within the United States for a complete, consistent system of physical measurement, adequate in all areas of science and technology. The second part is to provide essential services leading to accurate and uniform physical measurement throughout the $\mathrm{Na}$ tion's science, industry, and commerce. Included in these services are the calibration of instruments, the provision of standard samples, and the assistance we render to the weights and measures officials in the States. The third part of onr mission is to use our measurement competence to provide data on the properties of matter and materials which are of importance to science, industry, and commerce, and which are not available of sufficient accuracy elsewhere.

To help us carry out this mission, we have been exploring the adequacy of onr present measurement services. We have found that many of the services we furnish in the calibration of instruments and apparatus are inadequate to the needs of modern technology, particularly the needs of major national programs inrolving atonic energy, high-speed aircraft, missiles, and space exploration. With the aid of the military agencies and industrial groups, such as the Aerospace Industries Association, a number of problem areas in measurement have been identified. As we cammot hope to work simultaneously in all these areas, we have attempted to devise methods of assigning priorities to the many new measurement services we are being asked to fumish. We have also encouraged the establishment of military and industrial standards laboratories which serve as intermediaries between NBS and the plant or shop. To aid these new laboratories in their work, we issned during the past year NBS Handbook 77, Precision Measurement and Catibration. This three-volume handbook is a selective compilation of our previous publications, many of which are now out of print, in the important areas of measurement and calibration.

'To strengthen NBS-industry cooperation in this general field, we have established a new advisory committee on Calibration and Measurement Services. This action was taken in cooperation with a number of the major industrial trade associations of the country, such as the Aerospace Industries Association and the American Ordnance Association.

We have also been cooperating with the George Washington University in establishing a new curriculum dealing specifically with the science of precision measurement. 'The new course of study, announced this past winter by the miversity, will lead to degrees in 
this fiekl. The importance of this program has bought support from a number of industrial organizations.

During the formative stages of the program, the Bureau has been supplying some teaching and facnlty assistance to the university. If the new curriculum is successful and is adopted in other miversities. it will do much toward improving the measurement competence of the Nation in the rears ahead.

March 3. 1961, was the National Burean of Standards' 60th anniversary. Tre had a little celebration on this occasion, a sort of fanily-type party at which the Secretary of Commerce and his associates were present as well as other Government officials who are concerned with NBS.

At our birthday celebration we featured the fact that we were in the midst of planning to relocate the Bureau to our new site at Gaithersburg, Maryland, about 16 miles northwest of here. I have mentioned our relocation plans to you before, but this past year has seen a rery important transition in the program: the planning stage has come to a head and we are now embarking on the building stage. The Congress gave ns $\$ 23.5$ million for fiscal year 1961 to start the construction of nem laboratories. The first contract was let a fer meeks ago and ground will be broken tomorrow morning for this important acquisition of facilities.

The are having a simple ground-breaking ceremony and have invited your Chairman to be present to represent you at this important erent. If our facilities at Gaithersburg are completed reasonably well on schedule, we shall be able to invite you to our new laboratories by the time of the 50th National Conference on Weights and Measures.

Finally, I should like to bring to your attention certain administrative actions and decisions within the National Bureau of Standards concerning our weights and measures program. I think many of you are aware that for several years I have felt that the National Conference on Weights and Measures should receive stronger assistance from the Bureau toward increased accomplishments and influence. Tre have explored many of the possibilities and have finally arrived at certain conclusions that I wish to report to you now.

Effective July 1, 1961, two organizational changes will be made in the reights and measures area at the Bureau. This action is being taken in order to maintain and strengthen our contribution to State and local weights and measures agencies and related business and industry, to place Bureau sponsorship of and contribution to the National Conference on a higher and more independent level, to give specific direction to the more technical aspects of the Bureau's weights and measures activity, and to bring our weights and measures program into organizational conformance with other technical programs.

First, there will be created the position of Assistant to the Director for TWeights and Measures Administration. The incumbent will report directly to me and will be designated to serve as Executive Secretary of the National Conference on Weights and Measures, and as Chairman of the Weights and Measures Advisory Committee.

The Assistant to the Director will also be responsible for the derelopment of recommendations dealing with model laws and 
regulations and for maintaining a program of personal contact with weights and measures officials and their associations. He will serve as the channel for the dissemination of appropriate advice on administrative matters.

Secondly, we are attempting to strengthen the technical activities of the Office of Veights and Measures itself. The Office will continue to administer its present program, but organizationally it will be removed from the Office of the Director, where it is now located, and will take its place among the other technical operating units of the Bureau. The relocated Office of Weights and Measures will be responsible for technical measurement activities in weights and measnres areas, specifically matters dealing with testing equipment; testing procedures; specifications and tolerances for commercial weighing devices; the design, construction, and use of standards of weights and measures, including new State standards and instruments; and the program for the training of State and local weights and measures officials in the technical aspects of their work.

As you can see from what I have said, the Assistant to the Director will carry out those activities associated with the Office of the Director that have previously been performed in the Office of Weights and Measures. The Office of Weights and Measures is much smaller than the other technical operating divisions of the Bureau; for that reason we will continue to call it an office rather than a division, but in all other respects it will be treated as one of the Bureau's technical operating divisions.

IV. S. Bussey is to be appointed as the Assistant to the Director for Weights and Measures Administration and M. IV. Jensen is to be appointed Chief of the Office of Weights and Measures, effective July 1.

I recognize that what is being done will require certain modifications in the organization and procedures of the National Conference as presently constituted. I am confident, however, that the Conference will cooperate with us in this matter. The Conference Secretary will have the specific amendments to propose to you later in this meeting, and I trust that you will give your manimous consent to the support of Mr. Bussey's proposal.

Now, before turning the meeting back to your Chairman, I should like to announce certiin appointments which it is my responsibility to make as ex officio President of the Conference. These are as follows:

'To the Committee on Education to sncceed Howard E. Crawford of Jacksonville, Florida, I appoint .John 'T. Daniell of Detroit, Michigan.

Next, to the Committee on Laws and Regulations to succeed George I. Johnson of Kentucky, I appoint Agust in E. Diaz of Puerto Rico.

To the Committee on Specifications and Tolerances, to succeed Donald M. 'Turnbull of Seattle, Washington, I appoint H. J. McDade of San Diego County, California.

All three of these appointments are for 5 -year terms.

This concludes the matters that I have to report to you at this time. I appreciate very much your attention. I appreciate even 
more the opportunity I have had, and shall eontinue to have, of working with you toward the important objectives of this Conference.

\title{
PRESENTATION OF IIONOR AWARDS
}

Dr. Astin presented "Honor Awards" to 18 members of the Conference who, by attending the 45th Conference in 1960, reached one of the four attendance eategories for which recognition is made-that is, attendance at $10,15,20$, and 25 meetings.

\section{IIONOR AWARD RECIPIENTS}

20-Year Certificates

IV. S. Busser, D. W. Kingsley, R. E. Mcek, C. C. Morgan.

15-Year Certificates

S. H. Christie, Jr., L. G. Close, H. E. Howard, W. E. Louthan, R. D. 'Thompson.

\author{
10-Year Certificates
}

Mrs. F. C. Bell, J. A. Bcrnard, R. K. Bodenwieser, A. H. Dittrieh, J. E. Mahoney, Joseph Shaw, C. H. Stender, C. E. Wagner, O. H. Wiatson.

\section{ADDRESS}

By P. C. Brinklex, Commissioner, Department of Agriculture and Immigration, State of Virginia; representing also the National Association of State Departments of Agriculture

I am happy to have this ehance to speak before this great Conference again.

I had that pleasure at your 1958 National Conference, and I told you then that weights and measures was one of my favorite subjects. I can tell you now that it is still one of my favorites.

And I can also tell you that the National Association of State Departments of Agriculture is still vitally interested in weights and measures, because once again I am representing that organization, and bring greetings from them.

If I had time, I could tell you that since I talked to you last time, we in Virginia have increased our weights and measures force by about half and increased our appropriations by about threefourths.

I could also tell you that we have inereased our checking of largeeapacity scales by one-third and our small scales by one-fifth, and that we have increased our checkweighing of prepackaged foods until last fiscal year we passed the half million mark, and this year we will pass $2 \frac{1}{2}$ million packages.

I could give you the latest report on our cheekweighing of lime, fertilizer, and feed and tell you that there has been a really splendid improrement in the picture for these commodities, and I could tell you that the seed industry in Virginia is also moving along toward a true net for net method of selling.

I could tell you that we have moved into a new field of cheeking on the fill of milk cartons from the dairy plant and an old field of ehecking bulk tanks on the dairy farm.

But these are points of progress that any good weights and measures man can bring about, if he has the men and the money, and 
the laws and regulations, and the backing of top management that he ought to have.

What I really wanted to talk to you about is this item of management, because if we have good management we do not have as much trouble getting the other ingredients of a good weights and measures program.

The first ingredient of course is the law itself.

If we are only interested in testing scales and do not bother much with other parts of the weights and measures job, this business of law is not so hard to handle. All we would really need is a law saying that scales must be accurate.

But we do not have to get very far into weights and measures work before we find out that the business of buying and selling will not stand still for any law. So if we are to do our job and our whole job, we must see that our laws and our regulations attempt to keep pace with modern merchandising.

This past year in Virginia, we have completely rewritten our weights and measures law so that we can submit it to the 1962 General Assembly.

First, we prepared a rersion based on the model law and our experience in the field. Then we went over this version sentence by sentence with our Weights and Measures Advisory Committee from industry. Then we mailed out over 800 copies to interested persons, including about 40 trade associations of one sort or another, and of course including each member of our House and Senate.

I suspect that most weights and measures men would feel that this was pretty risky business, submitting a whole new weights and measures law for everybody to shoot at in the legishature.

But our experience with other laws has been that when most of the people directly concerned know what you are plaming to do, and have each detail explained to them, a good deal of the anticipated opposition is pretty well spiked in adrance.

This is particularly true if you hare taken pains to build up a reputation for being fair and for getting the job done. In Virginia we have always figured that in the regulatory field, we had two jobs to do, and that they had to be done together:

One was to protect the consumer where he conld not protect himself. The other was to create an atmosphere in which industry could thrive and prosper.

I believe that success in any phase of weights and nueasures depends on how well you can balance these two objectives.

To sum np the essentials of providing enough authority, both in the law and in its regulations, let me say that the people subject to laws must know what you propose and must have confidence in the man who proposes it.

This is tme all the way up the line with a State department of agriculture or within a weights and measures section. If you make sure that the mam at the top knows what you are trying to do and that he has confidence in you, most of your troubles with management are orer.

But both of these requirements add up to one thing, and that is, meticulous attention to detail. 
Attention to detail is a basic necessity in the second ingredient of a. good weights and measures program, and that is financing.

No weights and measures program is going to operate without money, and money is harder to get all the time. But if we understand the process of getting it, sometimes it comes a little easier.

The job of any legislature is to divide up the total number of dollars they have among the people and agencies and programs that ask for some. In most cases, there is not enough money to meet all requests.

In the process of budget cutting, the legislature is going to be guided pretty much by what its members are persuaded the need is.

This same procedure follows on down the line of budget approval. First, the head of the division in which weights and measures is located must be persuaded of the need. Then the Commissioner himself must be persuaded. Then the legislature must be persuaded.

'This is a lot of persuading, and it takes a lot of facts and details to get it done. In Virginia, Tom Harris begins preparing his budget 18 months before the General Assembly meets, and he builds his case like a lawyer building a brief for the Supreme Court.

When he gets through, it is kind of hard to argue that he does not need that much money. After talking the budget over with him, I am pretty well armed to go to the legislature.

Of course, what this really means is that Tom has been out there getting the job done. This is the only way he can determine the needs and justify them in terms of dollars.

But we are in the process of setting up IBM equipment that will tell us even more about the needs in weights and measures work and in many of our other regulatory and marketing functions. This equipment will analyze our inspection reports and pinpoint the places we need to concentrate on and give us even incre complete and detailed information on needs.

Using this equipment for program analysis in our fertilizer inspection program, we have alresdy found that we can increase our overall effectiveness many times by concentrating our time and men and money where the problems are.

There is another whole area where we can all increase our effectiveness, and that is the field of communications. I mean just telling the other folks who are concerned what we are doing and what we plan to do.

The most obvious kind of communications, and the kind we seem to forget most often, is internal communications. We forget sometimes that nearly every other section of a department is affected by what weights and measures people do.

For instance, we found in Virginia that we could make our program of checkweighing fertilizer much more effective by first making a survey. Then we showed the industry the survey results, it was much easier for us to get the industry into compliance.

That was an example of good communications. TVe do not always do that well. Our dairy inspection folks went to a convention recently and found themselves besieged by milk processors wanting to know what we were doing changing our regulations on the size of milk containers. The dairy inspection force did not know. 
They did not find out until later that Tom Harris was also at the convention with copies of our proposed new weights and measures law.

I do not believe there is anything that makes a public agency look quite as bad in the public eye as to be in the position where the left hand does not know what the right hand is doing.

You can get in pretty bad too if you have a breakdown in external commmnications. Most of the public relations fires we have to try to put out got started because we did not explain what we were trying to do, or what we were going to do, or what we had already done, to somebody.

In Virginia, we have found that a most effective method of doing this is through industry advisory committees. These are committees from industry that we pick out to meet with us on a regular basis to hear us explain onr problems and to keep us informed about the workings of that industry.

TVe have had some pretty warm sessions in some of our advisory committees, but as soon as the members saw that we wanted to be reasonable and were genuinely interested in getting a good job done, they were more than willing to meet us halfway.

I have already told you how far we go in trying to keep everybody informed when I listed all the people who got advance copies of our revised weights and measures law.

'This business of building good communications is like building a marriage. Yon have to keep working at it all the time. If you do, it pays tremendous dividends. If you do not, it can make your life pretty miserable.

Another tool we put to use in our weights and measures work is information. It should go without saying that if a man knows what he is supposed to do muder the law and if he knows who is enforcing the law and how it is being enforced, he is much more likely to comply voluntarily.

TVe all know for sure that there will never be enough men or enough money to keep every single soul honest in the field of weights and measmes. Our law enforcement is going to be effective in direct proportion to the voluntary compliance we can encourage.

So it is up to ns to put out all the information we can about our work and keep as many organizations and key people as we can informed about what we are doing in the field.

These are some of the techniques we can use to help onrselves do a better job in weights and measures, and I know of no area where we need more to nse every technique we can to constantly do a better job.

Ve all know that weights and measures is an area in which the responsibility is largely on the State and the locality to get the job done, and by and large it will always be that way, becanse so much of weights and measures work must be done at the point where the goods are turned over to the consumer.

If we neglect our responsibilties, however, we are in a poor position to complain if the people demand that somebody fill this need that is so vital.

We get wonderful help and cooperation from Federal agencies, particularly the National Bureau of Standards, but ours is the legal 
responsibility for weights and measures in our respective States and localities. Onrs is also the moral responsibility to be true to on: jobs, true to the people we are duty bound to protect, and most important of all, true to ourselves.

'There are really only two ways to go at any job, including weights and measures. One is to do as little as possible and stir up as little trouble as possible. The other is to do the job as well as we know liow.

The second way is much more difficult. 'The path is straight and narrow and usually studded with stones. It requires a bigger and a better man to walk that path, because there are always those who watch and wait for the slightest slip.

But if this path be liarder, the rewards inevitably are greater. This is the great truth of life.

There is no greater reward for a man than the satisfaction of a job well done and no greater peace than the sleep of the man whose conscience is clear.

\section{PACKAGE STANDARDIZATION-A MORAL OBLIGA'TION}

\section{By R. W. Coxve, President, Distitled Spirits Institute, Inc., Washington, D.C.}

Youx invitation for me to appear here today is felt by the membership of my organization to be a singular honor. Obviously, there is great personal satisfaction in addressing you.

As I appear before you to discuss the moral obligations of manufacturers in their commercial dealings, I respect the fact that I am speaking to the Nation's chief protectors of honorable commercial transactions. While you are not the Federal Trade Commission, you are primary monitors of honest transactions between the oftforgotten consumer and the seller.

The Distilled Spirits Institute, which I represent here, is a trade association of domestic distilling companies that account for more than 70 percent of the distilled spirits sold in the United States. The Institute last year made an appearance before the Alcohol and Tobacco Tax Division of the U.S. Internal Revenue Service at which it vigorously opposed a proposal of a small but powerful group in the industry to permit the use and sale of nonstandardized bottles.

When national prohibition was repealed in 1933, the Federal Gorernment established eight standard sizes of liquor bottles. The standard sizes have been in use for the past 27 years. The proposal for change made by this small group would permit packaging in any size bottle or, in lieu of that, allow bottling in a number of additional sizes.

The Institute membership felt that approval of either of these proposals would lead to the perpetration of a gigantic fraud upon the public. It felt that the packaging standards that had been laid down by the Federal Government had become known over the years to the consuming public; that these sizes were not conceived in fraud; that they generally emulated the common law with respect to standards; and that they should be continued unchanged both as being sufficient for the needs of the public and as being necessary to preserve the integrity of a very large industry. 
I take it, ladies and gentlemen, that the position of our organization for maintenance of standard bottle sizes has some relationship with my appearance here today. To be frank, if this intraindustry battle had not occurred last year-and, incidentally, the Federal Govermment has not yet resolved the issue-I believe that I and my associates would not have come to know the work and the value of the work of the National Conference on Weights and Measures, of the weights and measures officials throughout the comntry, and of this particular function of the National Bureau of Standards and its splendid personnel.

Most people have no real comprehension of the work of Federal, State, county, and municipal weights and measures officers. Too often we take it for granted that in ordinary commercial transactions the parties on both sides will for the most part be fair and square. We tend to forget that the majority of such transactions are on the up and up only because people before us had the sense to write into law standards for fair and square dealing and to provide for efficient enforcement of such laws through weights and measures officers. These predecessors recognized the need for standards in commercial dealings and for the enforcement of such standards as they had also recognized the need for policing authorities to curb crime and of the judiciary to administer justice.

I feel that the greater part of the public needs better mnderstanding of and education in your vital work. Like my associates and myself, we just never give your work the attention it should compel. Tie do think of the judiciary-because of the frequent appearance in news stories of spectacular court cases. But I find it difficult to remember public recognition of your work both in establishing and in enforeing standards in our commercial life, and I doubt that I would be here today if the firms I represent did not get into a bitter struggle about standard-size bottles. I know, of course. I would not be here if my team did not represent the ideals which you are dedicated to uphold.

The industry I represent is acutely aware of its social responsibilities. Then it sought and received the assistance you gave it, as a matter of principle, it was and is truly overwhelmed with gratitnde. As a matter of information, you and we were joined in opposition to the odd-size bottle proposal by the Liquor. Control Commissioners of practically all States, as well as by the Tax and Revenue Commissioner's of many States.

I mention, merely in passing; that Institute members imposed on themselves self-discipline of an musual nature. This discipline is embodied in a series of resolntions passed by the board of directors of the Institute which collectively we call the DSI rolunteer code. It is noterorthy, too, that some industry members, not presently DSI members and therefore not responsible to the Institute, adhere strictly to the Institute's rules. I trust they share our pride in their adherence to the self-imposed code.

Federal regulations presently hold that standards of fill, the absence of which connotes deceptive packaging, are necessary to prerent consumer deception. The Federal Alcohol Administration Act of 1935 spells out some of the details of packaging in a section designed to prevent "Unfair Competition and Unlawful Practices." 
Wo and your spokesmen held at the ATTD hearings last year that destandardization of bottle sizes would be an invitation for a conscionable industry to indulge in rank consumer confusion and deception.

'The hearings brought forth testinuony from both public officials and a fourth or fifth estate of citizens, such as 'The Consmmers Union, that deceptive packaging today is a monstrous fraud on the public, is widespread and wasteful, and endangers our free enterprise system.

'The hearings brought forth evidence that there are two types of deception involved in packaging. One is the matter of fill-an S-inch-wide package may contain only 5 inches in width of consumable contents, the remaining width containing nonconsumable filler miaterial such as paper or cotton, or what-liave-you. I understand the Federal Food and Drug Administration is presently conducting a drive to stamp out this type of fraud.

The second type of fraud-and that which our organization is trying' to prevent-pertains to container' sizes. 'The hearings brought ont that consumer deception in this field is widespread. One witness pointed out something that you officials are acntely aware of, but of which the unsuspecting public is largely uniware.

He said that in any number of instances he found that the large "economy" size or "family" size package of a number of products found in the ordinary supermarket, where our wives slop, costs more per ounce than the smaller size package of the same product. In other words, the consumer was being misled into thinking that the "economy size" was truly economical.

Tithout elaborating on details of our last year's case with the Federal Government, let me point out that one proposal would have permitted the bottling of the $2 / 3$ quart, or 21.333 ounces. While the popular fifth bottle is not a multiple or binary submultiple of the standard quart, it was adopted along with the standard multiples and submultiples of the gallon measure by the Federal Govermment because the size had, in effect, achieved its own standardization both in our country before prohibition and even before then in Europe.

I realize the fifth size has been opposed by this group. I might well oppose it if it were first proposed today. Its historical existence and its widespread use in Trorld War II, when conservation was a purpose, gire warrant for its present acceptance. Its acceptance, however, does not justify compounding of a danger of deception by abandonment of the multiple and binary submultiple principle.

TVe contended that proponents of the change aimed at selling the lesser size at the same amount as now charged for the larger size. Further, we held that competition would inevitably force the whole industry to do the same thing-use odd-size bottles-thereby giving the public less for more.

Treights and measures standards and the integration of the distilling industry's issue into the context of this important subject warrant great care and respect. For centuries, weights and measures problems have commanded the attention of philosophers, theologians, lawmakers, and merchants. Their roots in antiquity are not easy to find. 'They are there, however, for those who look. 
They compel one to regard with awe and even reverence their consideration through the ages as a vital implementation to human relationships.

In ancient writings we find not complete answers, but bench cuttings and trail marks that guided them and should guide us. The division of the fruits of the earth and the product of man's toil was the seed of contention leading to strife and murder, war between the tribes of old, and between the obscure groupings that preceded the tribes. The terms of dealing in man's substance were evolved through bitter experience and at great price. These standards were hard come by. Deviations, however plausible and whatever the surface attraction, warrant consummate caution.

"Let the buyer be present when the wine is drawn" began an English royal pronouncement of fair measure.

One liundred forty years ago, as so many of you know, John Quincy Adams wrote: "When weights and measures present themselves to the contemplation of the legislator, and call for the interposition of law, the first and most prominent idea that occurs to him is uniformity. . . His purposes are uniformity, permanence, miversality, one standard to be the same for all men and for all purposes, and to contimue to be the same forever."

As far as providing the public with adequate information about a product, distilled liquor, probably more than any other commodity, has been of never-ending public concern throughout the history of our country. This is understandable because of the fact that there are so many elements involved in appraising the product-the quantity, the strength, the quality, the age, the class and type, and even the place where produced, just to mention a few. It is not surprising, therefore, that we find standards of fill and measure for alcoholic beverages to have been a subject which occupied the attention of the earliest American colonial lawmaking bodies. The Grand Assembly of the Virginia Colony at its session of 1661-62, held at James City, enacted Act XCVII reading as follows:

Whereas, continual complaints are made of the exactyon of ordinary keepers and others in the rates and measures of strong drinke by them retayled and sold, Be it cnacted that noe person after the first of March 1603, shall sell or rend by retayle any wine, beere or other strong drinks of what sort soever by any neasure but English sealed measures of pints, quarts, pottles [half-gallons] or gallons, and that every one that now doth or hereafter shall keep any ordinary shall by the said first of March 1663 provide such measures to sell by in his house; and in case he fails, to be put down from keeping any ordinary, and fined five thousand pounds of tobaceo to the use of the publique, Provided alwayes that it shall be lawful for them to sell strong waters conteing over in cases by the bottle in the same bottles they bought them.

A historian ${ }^{1}$ tells us in the following words the reason for the passage of this act:

Notwithstanding the additional restraints before mentioned (licenses, bonds, etc.), violations of the act fixing the prices of drinks continued to harass the assembly, Ordinary keepers who were too conscientious to sell above the fixed rates, did not hesitate, it seems, to establish their own standard of measures, by the use of which they practically evaded the law, without exposing themselves to punishment.

1 G. Allus Thomann, "Colonial Liquor Laws, Part 2, Liquor Laws of the United States, Their Spirit and Effect," p. 52. 
So, while it is unquestionably true that the distilled spirits industry, due to mounting costs and over-heary taxation, faces a dilemma of sizable proportions, we do not, like the tarern-keepers of 1660 , seek a solution of the problem by establishing one own misleading standard of measures.

The purpose of standards of weights and measures is to inform, but not to confuse and deceive. Quality, quantity, and price seem to be the basis for the ordinary shopper. Through appropriate standards, we emphasize quality and cost, and deemphasize quantity, an opposite of quality. With your grace, I repeat that our common task is to emphasize quality and cost, and to deemphasize quantity.

Proponements of more bottle sizes support their request for adoption of odd-size bottles on the ground that it will permit the industry to "package to price." The term itself connotes deception in that it sngests giving the consumer less for his money, accompanied by a juggling of package sizes. With surprising candor, proponents, in their brief requesting the change, admit this objective in the following statement:

Industry, generally, has found it necessary to package to price so as to aroid increasing prices by reducing the size of the packages on foods. The distilled spirits industry faces similar problems due to the squeeze between rising production costs and unit prices. . .

In a related field, razor blades, packaged 21 to a container, are now being sold 18 to a container, but at the former price. . . .

It would appear therefore that the food industry, generally, is up against the same inflationary problem and that they have had to increase their consumer unit prices but have done it in part hy increasing the dollars and cents price and in part by decreasing the package quantity.

In short, the "packaging to price" plitosophy, stripped of its verbiage, is merely a price-raising device to be accomplished, not by the conventional method of raising the price of an existing bottle size, but by a more subtle method of reducing the size of the container.

Proponents of odd-size bottles, in support of their position, point to the reduction in sizes of packages of certain other commodities, giving examples of items ranging from cereals to soap pads, and caption the list "Packing to Popular Price Consumer Wants To spend." Among the itens which proponents cite as an example of "Packing to Popular Price Consumer Wants To Spend" are found the following:

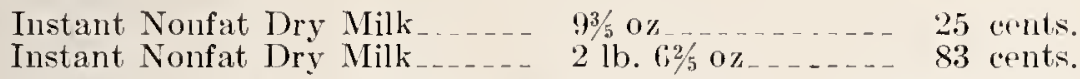

With the aid of our slide rule and expert mathematicians, we have arrived at the following compntations in relation to these tro size packages of the same product: the smaller package is priced at the rate of $2.6041+$ cents per ounce, and the larger package at the rate of $2.1614+$ cents per ounce. 'Thus, if the housewife had taken her slide rule and an expert mathematician with her to the supermarket, she would have been able to determine that, by buying the larger package of dried milk, she would have saved 0.4427 cent per onnce. Had the smaller package of dried milk been packaged in an 8-ounce package (that is, one-half pound), the price at the same rate would have been 21 cents. Thy a $93 / 5$-ounce package at 25 cents is 
a more "popular" price than a package of 8 ounces at 21 cents we are not informed. Nor do we know why the larger package of 2 pounds $6 \%$ ounces is better than if it had been packed in a $21 / 2$-pound package at 87 cents. The do say that the consumer could compare the relative values of a $1 / 2$-pound package at a cost of 21 cents and a $21 / 2$-pound package at a cost of 87 cents, but that the consumer could not possibly make a value comparison between a $93 / 5$-ounce package at 25 cents and a 2 pound $6 \%$ ounce package at 83 cents. Resultant consumer confusion is the inevitable result, if indeed not the basic motive of packaging in containers of a capacity which leaves the consumer utterly helpless in comparing values. WVe and you asked the A'T'TD, in view of the responsibility which the law places upon the Treasury Department, to prevent consumer deception as to container sizes of distilled spirits so as not to open the door to ntter confusion in the packaging of distilled spirits.

While, as we have emphasized, there is consumer deception and confusion inrolved in the ill-intended odd ounce and fractional ounce packages of some commodities, we should point out that there is no Federal Dried Milk Administration Act, but there is a Federal Alcohol Administration Act requiring distilled spirits to be packaged in containers which will not deceive the consumer. Secondly, consumers have not been accnstomed to ordering dried milk or soap pads by the quart, or by the pint, but that is the traditional way of buying distilled spirits. Thirdly, grocery and household items are sold primarily in self-service markets where the purchaser at least has the opportinity of inspecting the package before dropping it into a shopping cart. But spirits are still sold crenerally over the comnter, and if a purchaser orders a "fifth" of liquor he will ordinarily accept without inspection a bottle of relative size which is passed to him, even thongh through design or mawareness the clerk might pass him a 21.33 -onnce bottle instead of 25.6 ounces.

In listing commodities which are packaged in irrationally sized packages. proponents of odd sizes fail to mention that there are a large number of products which under State laws, as you know, are required to be packaged in containers of a specified capacity. In most every State, fresh fluid milk may be sold at retail in containers of 1 gallon, $1 / 2$ gallon, 3 pints, 1 quart, 1 pint, $1 / 2$ pint, and 1 gill only. Similarly, butter may be sold at retail only in packages of $1 / 4$ poimd, 1 pound, or multiples of 1 pound. Many other products, if prepackaged, are required by the States to be sold only in packages of a specified weight or capacity, such as bread, flour, oleomargarine, and in some States even a bunch of carrots must contain a specified number of carrots.

State, county, and municipal governments have a vital interest in the subject matter of liqnor bottle sizes, and the Federal Government consequently has a grave responsibility to the States in considering the establishment of new standards of fill for distilled spirits.

From the beginning, administrators of the FAA Act have sought to enconrage the States to adopt the FAA regulations relating to labeling and advertising. In response to this encouragement, many of the States have adopted in whole or in part $F A A$ regulations relating to labeling, advertising, standards of identity, and even standards of fill. As to standards of fill, there has been little pur- 
pose in a State adopting the Federal standards, since such Federal standards applied whether or not adopted by the States. 'The FAA standards of fill have governed container sizes in interstate commerce, and Internal Revenue container regulations have made these standards between $1 / 2$ pint and a gallon applicable to intrastate transactions. In the main, therefore, the States have confined their regulation of container sizes to prescribing minimum and maximum size containers and have accepted the Federal standards between such minimums and maximums. Only six States ${ }^{2}$ have prescribed specific standards of fill for distilled spirits, and three more ${ }^{3}$ have made a blanket adoption of Fld standards. 'Thus, the vast majority of States which either have not adopted standards of fill in reliance upon the protection afforded by FAA and Internal Revenue regulations or which have made a blanket adoption of FAA standards would have imposed upon them, in effect without their consent, the odd-size containers adrocated by proponents in the event of amendment of FAA regulations to authorize the same. The States which have relied upon Federal controls are justly entitled to protection of regulations they have adopted-regulations which were patterned at the Federal level.

In addition, 11 States ${ }^{4}$ would levy a tax penalty on the consumer by the use of one or more of the proponents ${ }^{5}$ suggested odd-size containers either because the State tax is levied on the basis of a specified quantity (such as a pint) or fraction thereof, or because tax stamps are provided only in specified denominations, any intermediate size container being required to bear a stamp of the next higher denomination.

It is interesting to note that the $1 / 20$ gallon advocated by proponents of new sizes would, under existing State laws and regulations, be an illegal package in 18 of the 32 license States ${ }^{5}$ and would undoubtedly be refused listing by most all, if not all, of the 17 monopoly states. 'This would leave only a potential market for the $1 / 20$ gallon in 14 States, and we have not the slightest doubt that this potential market would be promptly and substantially curtailed by State action.

Internal Revenue container regulations have from the very beginning ${ }^{6}$ complemented the $\mathrm{F} A \boldsymbol{A}$ standards of fill by adopting these standards as applied to containers of a capacity of $1 / 2$ pint or more. These container regulations are promulgated under the sole authority of the provision of the Internal Revenue Code authorizing such regulations when the Secretary or his delegate deems such necessary to protect the revenue. 'Thus, it must be presumed that the proposed $1 / 3$-gallon, 1/6-gallon, and 1/12-gallon-size containers must have been prohibited for protection of the revenue.

The U.S. Supreme Court has said that: "Laws are made to protect the trusting as well as the suspicious." 7 And a Federal District

2 Georgia, Indiana, Kansas, Minnesota, Oklahoma, Texas.

3 California, Delaware, Massachusetts.

4 Arizona, Colorado, Florida, Indiana, Fentucky, Louisialla, Missoul’i, Nol'tl Dakota, South Dakota, Tennessee, Wisconsin.

5 Arizona, Arkansas, Califormia, Connecticut, Georgia, Illinois, línsas, Kentucky, Louisiana, Minnesota, Missouri, Nebraska, New Jersey, New York, Rlode lsland, South Carolina, Tennessee, Texas.

6 Internal Revenue Regulations No. 13, issued August 1934 in Art. 1 (e) stated in part,". . the regulations in that regard (bottle sizes) heretofore promulgated by tlie Federal Alcohol Administration being hereby adopted as a part of these legulations."

7 Federal Trade Com. v. Standard Educational Soc., 302 U.S. 112. 
Court, in holding that marking of net contents on the package is not sufficient to prevent misleading the consumer as to standard of fill under the Federal Food, Drug, and Cosmetic Act, has said that the standard is not whether experts or men of peculiar training, experience, shrewdness, or sophistication wonld be misled, but that the standard is whether the container would be likely to mislead the ordinary purchaser, not one who is particularly attentive or prildent. $^{s}$ 'Thus, the comrts have recognized the fact that statements on the label of a consumer package are not always adequate to prevent consumer deception.

It has been alleged that no foreign country places limitations on the size containers in which distilled spirits may be packaged. While we do not consider this in any way material to the issues involved in this hearing, we do challenge the accuracy of the statement.

We do know, for instance, that by law in Italy acquaviti (distilled spirits) must be bottled only in containers of a capacity of 0.1 liter, 0.25 liter, 0.5 liter, 0.75 liter, 1.0 liter, 1.5 liter's, and 2.0 liters. Under the weights and measures law of the Federal Republic of Germany, hard liquors may be bottled only in containers of the following capacities: less than 0.125 liter, 0.2 liter, 0.25 liter, 0.35 liter, 0.5 liter, 0.7 liter, 1.0 liter, 1.5 liters, 2.0 liters, 3.0 liters, and 5.0 liters. Canada, of course, controls the size containers of distilled spirits offered for sale in that country through its provincial liquor store setup, and an examination of the listings in the several Provinces discloses that Canadian whiskey is offered only in 12-ounce and 25-onnce bottles in the Provinces of New Brumswick, Prince Edward Island, Newfoundland, Ontario, Manitoba, Alberta, British Colmmbia, and Y Ynkon 'Territory. Some of the remaining four Provinces also offer Canadian whiskey in 10 - and 40 -ounce containers.

While Great Britain has not yet standardized containers for distilled spirits, at least it has made a move in that direction. For instance, in 1949 the British Board of Trade appointed a committee to review existing weights and measures and their administration "and to nuke recommendations for bringing them into line with presentday requirements." After exhanstive stndy, this committee, in a roluninons report presented to Parliament at the command of King George VI in Mary 1951, said:

We are, moreover, of the opinion that the interests of the public would be more adequately safeguarded, and that the recognized practices of the trade would not be disturbed by a further requirement that certain drinks of widespread consumption should be sold when in bottle, in specified and well-differentiated quantities only.

While, as stated in the begimning, we do not consider economic considerations as basic issues in last year's hearings, we think it unnecessary to state that the Distilled Spirits Institute is vitally concermed with the economic welfare of its members. However, we believe the adoption of the odd sizes advocated by the proponents, or any of them, would result in economic detriment to the industry rather than in economic betterment. 'The consumer would nltimately have to bear the additional costs represented by the costs of additional bottling equipment to the bottler, and the costs of additional

8 U.S. v. 116 Boxes, elc., 80 1. Supp. 911. 
inventories, space, and handling by the bottler, the wholesaler, and the retailer. The cost in loss of consumer goodwill would be in(apable of measmement unt il the damage had been done.

While proponents allege that the suggested off-sizes might replace reltain standard sizes, the facts of economic life would preclude any such total substitution. So long as one producer markets any specific container, competition will fore ofher producers to supply that size container.

The need standards in our society because our way of life compels us to be individualistic. We demand free competition. TVe demand the right to adjudge our laws in the way in which we view them. But, being civilized. we acknowledge our own shortcomings of intellect and judgment and we accept the fact that there are moral standards over and above our own view of looking at them. We actually give away part of ourselves when we conform to the dictates of a democratic society. We do not necessarily agree with all the rules laid down by a majority of our political representatives, but we nonetheless conform to them becanse we know that that sacrifice is made to perfect a nobler good, a better society; and thereby we improve our mode and manner of living. While we give a little of ourselves, we do not subject ourselves to the tyranny found behind the Iron Curtain.

The United States of America was created out of the torment of tyramny. It subsequently became composed of heterogeneous peoples with a common purpose: Freedom.

Thile it aimed for liberty in the structure of its society, it did not seek license. Its peoples agreed upon common rules of social and commercial intercourse. They agreed to standards in terminology, to methods of doing business, and they also agreed to disagree in many cases in philosophical, religious, and business concepts. But they agreed-agree today-to disagree in harmony, but to agree also to basic verities recognized by all. They set forth the highest standards of civilization ever before witnessed.

In World War I, our Government recognized the need to preserve essential raw materials such as iron, coal, steel, and glass. It immediately issued orders for standardization of packages in order to conserve these materials.

After World War I and the seeming decline of the necessity of preserving critical and strategic materials, we went back to free enterprise and heterogeneous packaging.

Meanwhile, producers of consumer goods, always in tough competition, recognized the values of prepackaging, and more and more of our commodities began to appear in prepackaged form. 'To mention but a few, milk, butter, lard, and sugar, and whisky too. The packaged commodity is now the staple of the supermarket. So packaging became the commercial art of the thirties.

Then once again came another world war-the second. And again the Government became concerned with raw materials and imposed hundreds, if not thousands, of standards, both in manufactured and packaged materials.

When the necessities of calamity, such as war, dictate, we become prudent and economical with our resources. Then we become in- 
dolent with largesse, our competitive system forces a spendthrift way of life which wastes our resources.

The distilling industry was fortunate in being re-created. It compelled the attention and scrupulous thinking of gorernment officials as to what would be the rules governing the industry.

These ofticials laid down standards of packaging which still hold after 27 years. They were derised for the protection of the public. They were agreed to by the industry. And the major part of the industry today wants them continued. This is admittedly selfinterest, but self-interest is vital to a sensitive industry. And I am grateful that our member firms recognize that fact.

If these remarks seem a little critical of onr free enterprise system, they are not so designed. They are meant only to deal with the facts of our economic life. Onr industry is dedicated to the competitive system and completely opposed to monopoly, which is the forerumner of socialism-merely a term for communism.

In conclnding this paper, I have two general comments:

1. Honest packaging is a moral obligation on the part of manufacturers.

2. Packaging in well-defined standard sizes is essential to the preservation of our free society.

In connection with paragraph 1, packaging that gets away from multiples or binary submultiples of a unit is frequently a designed deception of the public.

As to paragraple 2, standardization of sizes in all consumer items is necessary for two reasons.

First, nonstandardized consmmer packages will fool the people for only so long, and will in time generate a distrust for packaged commodities. This will, in turn, generate a distaste for American business practices and lead to ever more governmental intervention and ultimately the deep sleep and torpidity that comes from socialism. The torpor of the subjects of socialist states is worse than honorable reath.

Secondly, mass consumer packaging practices that eventuate in consumer disdain will, like prohibition laws, lead to a scornful public disrespect so as to jeopardize confidence in American business itself. And so they should.

We have been fortunate in our industry in having standards in packages fixed by the Federal Govelmment. But we recognize the danger's that beset our industry by lack of standards in so many commodities.

TVe know that you are truly dedicated to preserving American business, often in spite of itself. Please accept from us our cordial goodwill in the furtherance of your vital work.

\section{ADDRESS OF CONFERENCE CHAIRMAN}

By R. E. Mrex, Director, Division of Weights and Measures, Board of Mealth, State of Indiana

Is the Chaiman of the National Conference on Weights and Measures, it is my privilege to extend to each of you a cordial greet- 
ing and, at the same time, to express the hope that this, the t6th meeting of our organization, will prove to be one of the most ontstanding and worthwhile in its nearly lalf a century of service in the public interest.

It is not to be considered remarkable that the National Conference, an moflicial organization with no legal status and no authority to enforce its recommendations, has been able to accomplish so much in the entire field of commercial quantity determinations. The Conference is dedicated to the promotion of the principles of fairness, impartiality, uniformity, and equity in all matter's pertaining to weights and measures administration; however, factors other than dedication to worthwhile principles should be recognized in any discussion having to do with the success of the National Conference. I believe that a number of these factors are of suflicient importance that they should be named and briefly discussed.

To me, the greatest asset the Yational Conference can claim is the fact that it was created and has been continmally sponsored by the Tational Bureau of Standards. The Bureau uses this means of discharging part of the responsibility under that portion of its organic act which anthorizes "Cooperation with the States in securing miformity in weights and measmres laws and methods of inspection." Irithout the benefit of this sponsorship by the Burean and its many contributions in the way of administrative and technical guidance, publication, and research, all of which we hope will be continued and strengthened, there probably would not be a National Conference or, at best, a very weak and ineffective one.

Next to the contributions of the National Burean of Standards to the success of the Conference, I rould rate the splendid cooperation receired from those engaged in the manufacture, servicing, and operation of weighing and measming devices, business organizations, trade associations, gorermmental agencies, consmmer groups, and others interested in the objectives and activities of the Conference. The participation of these interested individuals and groups is of inraluable assistance to the Conference in arriving at sound, reasonable, and rorkable conclusions. It is to be recognized that differences of opinion, serionsly presented, may arise in seeking the proper solntion to any problem.' 'These differences of opinion are respected, and in no sense discouraged, by the Conference, as they present possibilities that, after carefnl stndy and consideration, are often accepted.

The Conference conld not be a success without the attendance and active participation of a good representation of State and local weights and measures officials. Conference officer's and members of committees have definite responsibilities that, in their proper discharge, reqnire long homrs of work over and above the individuals: routine activities. The opportunities for weights and measures officials to serve the Conference are many and, I might add, not limited solely to attendance together with the voicing of approval or disapproval of the work done by others.

The National Bureau of Standards and the various organizations and gromps mentioned are "cogs in the machinery" of the Conference that have proper places and responsibilities, that have worked togetlier objectively, and that, throngh mutnal respect and cooperative 
effort, have accomplished the greatest good for our entire citizenry. However, as an organization, we must not "rest on our oars" on the basis of past accomplishments, but instead should be ready to meet, intelligently and successfully, the challenges that will confront us in the future.

The observations I have made are based on my 28 year's' experience as a weights and measures official, my attendance during 20 National Conferences, and the service I have been privileged to render as an officer and as a member of varions committees of the Conference. I am pleased to have played a small part in the affairs of the Conference, particularly dnring the past year, to which I now will turm my attention.

During the closing session of the 45th Conference, your Chairman was directed to designate a special committee to stndy feasibility of the Conference being held in locations other than the District of Columbia. This committee, consisting of the five principal officers elected from the active membership, developed a consensus of those weights and measmres officials who normally attend National Conferences. The report of this special committee will be presented to the Conference later in this meeting.

During the past summer, the attention of the Conference was called to an attempt that was being made to break down the established system of standard mits for the sale of distilled spirits. The first proposal made by a small segment of the distilling industry to the Alcohol and 'Tobacco Tax Division, Internal Revenue Service, was to eliminate all specifie bottle sizes for distilled spirits. If farorable action was not taken on this proposal, it was requested as an alternative that the regulations be amended to add four additional sizes: namely, 1/3 gallon, 1/6 gallon, 1/12 gallon, and 1/20 gallon.

The Director of the Alcohol and Tobacco Tax Division, Hon. Dwight E. Aris, scheduled a hearing on this petition in Washington, D.C., for July 27, 1961. In the meantime, a memorandum calling attention to the hearing and its purpose was sent to selected weights and measures officials by your Chairman. As a result of this memorandum, approximately 100 officials sent letters to the Alcohol and Tobaceo Tin Division protesting the petition. In addition, several State and regional weights and measures associations adopted resolutions pointing ont that the grinting of the petition wonld not be in the best interests of the public.

Your Chaiman was one of a group of four present and former officials who attended the hearing and presented strong statements opposing the granting of the petition. Others in this group were T. C. IIarris of Virginia. J. P. McBride of Massachusetts, and C. M. Fuller of Los Angeles, Californial. We called attention to the position taken by the National Conference in the past on standardization of package sizes and, in particular, on containers for alcoholic bevemages. Onr argments were in the interest of standardization of package sizes wherever this was feasible, and the continuation of those standardization programs currently in effect. 'The point was made and reflected the belief that the real need was for fewer rather than more sizes.

It shonld be mentioned that, in addition to many other organizations, the Distilled Spirits Institute strongly opposed the granting 
of the petition on the grounds that standardization of package sizes as currently in effect was in the best interests of all parties concerned-the distiller, distributor, retailer, and consumer. Robert IV. Coyne, President. Distilled Spirits Institute, was so favorably impressed with the position taken by weights and measures officials on the importance of package standiudization that he kindly accepted an invitation to discuss the subject during this Conference.

Four Chairman was privileged to attend a nmmber of State and regional weights and measures conferences during the year and, upon fonr occasions, spoke on the topic "The National Conference on Weights and Measures-Its Purposes and Policies." 'These conferences were sponsored by the following weights and measures associations: Western, Indiana, Ohio, and Michigm. Many present at these meetings had never attended a National Conference and, therefore, had only a limited knowledge of the working arrangements of our organization.

Interim meetings of the National Conference Committees on Specifications and 'Tolerances and on Laws and Regulations were held at the National Bureau of Standards and the Sheraton-Park Hotel during the week of January 30. These committees held both public hearings and executive sessions. The Committee on Specifications and Tolerances held its meetings on Monday and Tuesday, and the Conmittee on Laws and Regulations met on 'Thursday and Friday. A joint meeting of the two committees was held on IVednesday. The public hearings were arranged for the purpose of giving all interested parties an opportmity to express their views prior to drafting, during the executive sessions, the tentative reports of the two committees.

It was my privilege as Conference Chairman to be invited to attend all meetings of the two committees and to offer any suggestions that I thought might prove helpful. I am, accordingly, better informed on the many recommendations of the two committees contained in the two tentative reports. As a result of this experience and what I believe to be its value to the presiding officer of the Conference, I recommend that similar invitations be extended to future Conference Chairmen.

I feel that it is in order to compliment all members of the two committees for their serious and untiring efforts to arrive at sound and reasonable tentative reports. 'To the other weights and measures officials and industry representatives attending the public hearings, I would like to voice the appreciation of the Conference for the helpful and considered expressions of their views. Even though it was not always possible to arrive at a unanimity on all matters discussed, it must be remembered that it is better to have any divergent or conflicting views expressed and to have these carefully studied and considered before arriving at either tentative or final recominendations.

Now that weights and measures officials, with the helplul assistance of the National Conference, industrial organizations, and various associations, have sponsored three "National Weights and Measures Weeks," I suggest that the results achieved be given careful study to determine whether or not the celebration of the "VVek" should be continued as a permanent Conference sponsored educational effort. 
Much can be said in farror of the "Treek," but there are those who question the advisability of concentrating our major edncational efforts dnring one week of each year. Some are of the opinion that the advantages of celebrating "TVeeks" are being dissipated due to the large number of organizations, apparently on the increase, that sponsor them. In one major city it was found that 12 different organizations were celebrating the same week and, for this reason, it was impossible to obtain official proclamations. Many have expressed the view that more farorable results wonld be obtained by periodically providing weights and measures oflicials with copies of prepared addresses, newspaper articles, and scripts for radio and television presentations. Regardless of omr individual thinking on this question, I am of the opinion that it is one that merits careful consideration by the Conference.

'This year, for the first time, the Conference is sponsoring a luncheon instead of the usual evening party. We have been fortmate in securing Hon. Philip A. Hart, U.S. Senator from the State of Michigan, to address us on this occasion. We hope that everyone registering for the Conference will attend this social affair scheduled on Vednesday.

In conclusion, I want to roice my sincere appreciation for the splendid cooperation I have received from the oflicers and members of the National Conference while serving as your Chairman during the past year. In particular, I want to acknowledge the nutiring efforts expended by your Secretary, Mr. Bussey, and members of his staff in looking after the interests of the Conference thronghont the year as well is in handling the countless details in connection with the arrangements for and the program of this meeting. I am sure their efforts will result in making this, the t6th National Conference on Treights and Measures, a most informative and ontstanding meeting. Is an expression of our appreciation of this courageous and eflective leadership and to exemplify our sincerity of purpose toward national unitormity and efliciency in weights and neasures administration, let ns, in our respective jurisdictions, rededicate onr lives and actions to the moral support, legal adoption, and effective enforcement of the rarious Conference recommendations.

SECOND SESSION-MORNING OF WEDNESDAY, JUNE 14, 1961

\author{
(J. W. D. Harver, Vice Chairman, ['resintng)
}

\title{
REPORT OF COMMITTEE ON EDUCATION
}

Presented by J. F. 'Thur, Chairman, State Sealer, Division of Weights and Measures, State Board of Agriculture, State of Kunsas

1. Publication of Conference Recommendations.- As the resnlt of a suggestion of the Conference Committee on Specifications and 'Tolerances, the Committee on Education presents for Conference consideration il plan whereby certain recommendations of the Conference may be formalized and published tor general distribution. The first area in which the plan is proposed is in device selection, installation, and maintenance. 
It is suggested that such Conference recommendations be reprodueed on paper of Iandbook $4 t$ size and punched for looseleaf binder use. If the plan is accepted, the Conference will request the Sational Burean of Standards to undertake the mechanical operation of preparation for and publication of the recommendations in number sufficient to provide each interested jurisdiction with a few copies. Freedom to republish is explicit in the plan.

The committee recommends the adoption of the plan of oflicial recommendtaions and the first such recommendation covering the selection, installation, and maintenance of vehicle scales, as follows:

\section{SELECTION, INSTALLATION, AND MAINTENANCE OF VEHICLE SCALES}

A Recommendation of the Vational Conference on Weights and Measures

\section{Selection}

1. A basic consideration in the selection of a scale is compliance with an adequate specification. Scales in commelcial service are subject to inspection and test by constituted weights and measures regulatory authorities, In the majolity of jurisdictions in the United States, the codes of specifications, tolerances, and regulations adopted by the National Conference on Weights and Measures have been promulgated. ${ }^{1}$ It follows that the purchaser of a scale intended for commercial service should do no less than to specify compliance with the National Conference codes, and that the purchase contract should include a warranty by the seller that the scale fulnished will conform fully to all applicable weights and measures requirements of the jurisdiction wher' it is to be installed. In the case of a scale to be purchased for noncommercial service (and so not subject to oflicial controls), the same minimum requirement is recommended as for commercial scales, to the end that a satisfactory weighing machine may be obtained. If a scale is to be operated under unusually rigorous service conditions, or if other special or unusual demands will be made upon it, a competent scale engineer should be consulted: if it is found necessary to prescribe special requirements beyond the minimum requirements encompassed by the National Conference codes, these should be carefully worked out and explicitly set forth in the purchase contract for the scale.

2. When selecting a particular scale, careful consideration should be given to (a) weighing capacity, (b) platform dimensions, and (c) the character of the indicating elements. In this relation, thought should be given not only to current needs, but also to needs anticipated for the succeeding 10 years or so.

(a) With respect to weighing capacity, it will probably be found to be economical in the long view to choose a scale with a nominal capacity of 20 percent or more in excess of the actual anticipated weighing requirements. This will promote longer life of scale parts, will be conducive to uninterrupted weighing service and reduction of maintenance expense, and will tend to avoid early obsolescence of the scale because of inadequacy of capacity to meet unanticipated weighing demands.

(b) It is contrary to good commelcial weighing practice, as well as to a regulation of the National Conference Scale Code, to attempt to determine the total weight of a highway vehicle by weighing it one end or one axle at a time and adding the results. A value so derived may be seriously inaccurate. The same is true in the case of coupled vehicle combinations-for example, tractor-trailer units-when the sevelal elements of the combination are individually weighed without first being disconnected from other elements of the

1 These codes are curlently published in looseleaf form in National Bureau of Standards Handbook 44, 2 d Edition, and are kept up to date-that is, in conformity with the decisions if the National Conference through the medium of replacement sheets issued annually. Copies of the handbook (including replacement sheets) mav be purchased from the Superintendent of Documents. U.S. Gorerument Printing Office, Washington 25. D.C. Upon his request, a purchaser of Handbook 44 will be suppled, without cost, with subsequent replacement sheets as these are issued. 
combination. The length of a rehicle scale should be adequate to accommodate in its entirety the longest vehicle or rehicle combination that it is proposed to weigh on the scale. Since it is usually expensive and may prove to he unsatisfactory to undertake modification of an installed scale to increase its length, it is ulged that, when deciding upon the length of a new scale, a liberal allowance be made over immerliate needs to care for future developments. For rehicle scales, a platfolm length of at least 50 feet is recommended unless it is known that needs will be restricted to the weighing of relatively short-wheelhase vehicles. Scales of 60 feet, 100 feet, or eren more in length are practical and are to be recommended when warranted by the character of the loads to be weighed. A minimum platform width of $1 \dot{0}$ feet is also recommended.

(c) The relative adrantages and limitations of manual (weighbeam) and automatic means for indication of weight values, and the desirability or need for weight registration on tickets, tapes, and the like, should be carefully evaluated.

Pnrchasers of scales intended for either commercial or noncommercial service will be well advised to avoid the false economy of sacrificing quality for low initial cost. A good scale. well installed and carefully maintainerl, will more than justify its cost by its long life and accurate weighing performance.

\section{Installation}

(Whenever, in what follows, reference is made to specific elements-as. for example. level systems, loarl cells, weighbeams-the comment refers only to those scales that incorporate such elements.)

The rigilance of the purchaser may not safely be relaxed even when an excellent scale has been selected, since, if the scale is not properly installed, it may fail to produce the results of which it is susceptihle-its weighing: performance may be seriously inaccurate or may shortly become so, and it may deteriorate rapidly in serrice. Installations poorly planned or unskillfully executed ton often result in new scales being turned over to their ownels in improper or inaccurate condition. The purchaser will, therefore, do well to see to it that the following basic requirenents are adhered to:

1. Site: The location of the scale should be such that smooth, straight, hardsurface approaches, level with the scale platform, may be provided for a reasonable distance (at least as long as the platform, if placticahle) at each end of the scale, that sulface water will drain away from the scale pit, and that nonweighing trathic neerl not go orer the scale platform.

2. Installation suprrvision: The entire installation should be made under the supervision of a competent scale erector, preferably an employee of the scale manufacturer, so that responsihility for the final accuracy of the scale and the snitability of the entire installation may be centered in a single agency.

3. Srale Pit: For proper scale maintenance-that is, protection against damage and deterioration of the scale parts and assurance of a continuance of acenute weighing performance-it is imperative that there be periodic cleaning and inspection of the understructure of the scale and, on occasion, that servicing operations and repairs he made to scale parts. For these reasons it is necessaly that arlequate room he provided so that an inspector or a repairman may move about the pit freely. Accordingly, the pit should be drep enongh and access thereto should be such as to facilitate inspection, cleaning, and maintenance of scale parts.

Pit walls and floor, and pirrs for level stands, should be of good quality concrete and should be pourer as a nnit.

Arlequate means shonld be provirled for pit drainage and rentilation.

4. Srale Elements in. the Pit: All stands should be set directly on concrete without intervening supports, and should be securely anchored in correct position.

All parts of the scale should be so positioned as to bring them into proper relation with each other, with adequate working clearances around all live parts.

All levers or load cells should be installed accurately lerel and in proper alinement.

11 bearing assomblies, comections between levers, the steelyard rod, the heam rod, and all other parts designed to be plumb, slould be installed in accurate vertical alinement. 
The pirots and bearings of the main levers and extension levels should be well packed with grease, fo protect these pards agalist collosion. Pivots and healings of slett levers, weishbeans, and of any extension of reversing level's installed between the transierse extension lever and the weighbeam or dial should be protected only by the tilm of oil remaining after these parts liave been wiped with an oily (but unsaturated) cloth. Grease or an excessive amount of oil on these parts will affect the sensitiveness of the scale-that is, its response to sinall clianges in platform load.

5. Wcighbridye: The weighbridge should be of steel, adequately strong, and suitably braced for rigidity, and should inchude steel members providing adequate support for the platform. Adequate working clearances should be prorided around the weighbridge.

Checking means should be provided and should be designed, installed, and idjusted to prevent excessive weighbridge movement without interfering with necessary weighbridge freedom during weighing operations. Ball or roller (hechs should be well pached with grease.

All structural steel should be painted to protect the metal against corrosion.

6. Platform: The platform should be of adequate strength and should be weathertight. The surface should be reasonably smooth and in surface alinement with the pit coping.

The opening between platform and coping should be established at approxiwately one-half inch at traftic level, and the edges of the platform should be undereut slightly to prevent lodgment of foreign matter between platform and pit wall.

7. Indicating Elements: The indicating elements should be adequately protected from the weather.

The weighbeam or automatic-indicating elements should, if practicable, be so positioned as to avoid the use of adcled extension levers between indicating elements and the normal lever system, and the installation should be so arranged as to afford the weighmaster an unobstructed view of the entire platform.

Indicating elements should be installed level and plumb, and should be rigidly mounted upon firm foundations, preferably a part of the walls of the pit neck, but in any event independent of the scale house, weighing room, or other similar structure. A weighbeam should be horizontal when its tip is at the midpoint of its travel in the trig loop.

Adequate clearances should be provided around the indicating elements aud the connections thereto.

8. Inspection and Test: During the progress of the installation, inspections slould be made to insure compliance with specification and installation requilements.

When the installation is completed, final inspection should be made and the scale should be tested for accuracy and sensitiveness, "acceptance" require. ments being applied. The test should, if practicable, be carried up to the nominal capacity of the scale, and in any event should be carried to that point in the weighing lange corresponding to the largest gross load expected to be weighed on the scale. The testweight load utilized should be as large as practicable up to the nominal capacity of the scale. Observations should be made at not less than three different test-weight loads. One or more strain loads should be utilized in combination with the available test veights when the amount of the test weights is less than the nominal scale capacity or the maximum anticipated gross lading.

\section{III.. Maintenance}

In order to prevent rapid deterioration of parts, to keep the scale in good mechanical condition, and to promote the continuance of accurate weighing results, the following instructions should be observed.

1. Regularly cleun the following: The scale pit. This should be maintained in clean and dry condition.

The scale parts in the pit. When the protective grease around the pivots and bearings of the lever systen become hard and dirty, clear the old grease away and repack the parts with frosh grease.

All structural steel in the pit. Keep this well painted to protect the metal. If rusting should start, thoroughy clean the metal before repainting.

The scale platform. Prevent all accumulations of dirt or foreign matter on or around the platform. 
2. Scale Platform: Keep the surface in good repair.

Maintain an opening of approximately one-half inch between the coping and the edges of the platform.

Maintain surface alinement between the coping and the traflic surface of the plattorm.

3. Scale Approaches: Maintain in hard and smooth condition and in surface alinement with the scale coping.

4. Indicating Elements: Keep weighbeam notches and poises clean, and maintain weighbeam bars and face plates in clean and Iegible condition.

Keep automatic-indicating elements clean.

Keep dash pots properly filled and adjusted in strict conformance with the instructions of the manufacturer of the automatic-indicating device or attachinent.

Handle all indicating elements with care, to avoid breakage of or damage to parts.

5. Gcneral: Keep the scale in correct zero-load balance, with any loose balancing material securely enclosed.

Do not overload the scale.

A rehicle scale is not well suited for precision weighing of gross loads of less than 1.000 pounds.

Keep indicating elements locked except when in actual use. To prevent inordinate wear of zero notch of weighbeam, the main poise should be positioned indiscriminately near the tip of the weighbeam when the scale is not in use.

Arrange for periodic inspection of the scale by a competent seale mechanic.

If scale parts become damaged or broken, arange for prompt renewal or suitable repair by a competent scale mechanic.

Ino not authorize or permit the grinding of pirots in the field; such work should only be performed in a scale shop furnished with the necessary specialized tools and equipment.

Contact the State or local weights and measures agency for additional information regarding the selection, installation, and maintenance of vehicle scales.

2. National. Technicul Training Schools for Instructors in Wheights and Measures Supervision.-Early in February the Office of Weights and Measures of the National Burean of Standards ammounced that it would conduct a special technical training school for instructors in weights and measures supervision. 'The annomncement noted that the size of the class would be severely limited and that, the considerations being equal, students would be accepted in the order that their applications were submitted.

'Thirteen weights and measmres supervisors from as many States. 11 representing State jurisdictions and 2 from large city jurisdictions, assembled on Monday, March 20, in the new training laboratory of the Office of Treights and Measures. Your Education Committee Chairman was one of those students.

'Those in attendance were offered a full week of intensive training in subjects embracing the broad ficld of weights and measures superrision, with special emphasis on the training aspects. There were lectures, demonstrations, discussions, practice teaching, and examinations-both oral and written. Fven the evening hours were occupied with study assigmments and lively discussions among the students.

Although the majority of the presentations were by stafl members of the Oflice of Weights and Measures, excellent lectures were deliyered by especially qualified individuals from the universities in Washington.

Erely man who attended the course and earned the coveted certificate was more than enthusiastic about the content, the presentations, and the fellowship. 
The Committee on Fdncation commends the Oftice of Weights and Measures and the National Bureau of Standards on this most worthwhile project. It is the firm opinion of this committee that every State and every large local jurisdiction should have on its staft at least one man who has undergone this intensive training. 'This will lead not only to greater efliciency within the jurisdiction, but also to greater conformity nationally.

It is the understanding of the committee that the Bureau will schedule additional courses of this type as the demand is indicated. The committee, therefore, urges weights and measures administrators from throughout the Nation to write to the Bureau and arrange for participation of key personnel in a technical training comrse of this nature.

3. Resolutions on Term "Consumers" Protection."-During the 4tth Nitional Conference two resolutions concerning the use of the term "Consumers' Protection" were introduced by delegates from Connecticut. These were referred to the Committee on Education. During the open hearing on Tuesday both resolutions were withdrawn by the delegates who originally introduced them.

t. Household Weights and Measures Card.-The committee has explored the use by weights and measures officials of the National Bureau of Standards publication identified as "Household Weights and Measures." Under the plan offered by the Bureau, it is practicable for individual weights and measures agencies to reproduce and distribute this as a publication of their own agency. Identification of the distributing agency is accomplished in a simple manner by inserting in the space provided the appropriate information. The committee has viewed several examples of such reproductions and is impressed with their value as an educational and public relations tool.

Weights and measures officials are urged to take advantage of this offer and obtain from the National Bureau of Standards at no cost master copies designed for photo-oflset reproduction and the insertion of whatever material it is desired be inserted for agency identification.

5. Appreciation to Subcommittee Chairmen.-For each of the past 2 years the Chairman of the Subcommittee on Public Education and National Weights and Measures Week has devoted his time and his talents, unselfishly, to the promotion and coordination of activities associated with National Weights and Measules Week. As everyone connected with weights and measures is aware, the results were outstanding.

As Chairman of the Committee on Education, I feel that the Conference should show its appreciation to Mr. J. E. Bowen of Newton, Massachusetts, and Mr. Carl H. Stender of South Carolina, for the fine service they have rendered by extending to them a rising vote of thanks, and I so move.

(A standing oration was given to Mr. Bowen and Mr. Stender.) 
During the year the committee has profited by the suggestions made and the cooperation rendered by weights and measures officials from thronghont the Enited States, and of representatives of the trade, and takes this opportmuity to register its appreciation therefor.

\author{
.T. F. Treue, Chairman \\ .J. E. Bowen \\ H. E. Crawford \\ IV. A. KerLin \\ C. H. STENDER \\ IV. S. Busser, Secretary
}

('The report of the Committee on Education was adopted by voice vote.)

\title{
REPORT OF SUBCOMMITTEE ON PUBLIC EDUCATION AND NATIONAL, WEIGHTS AND MEASURES WEEK
}

\section{Presented by C. H. STwnder, Chaiman. Assistant to Commissioner, Department of Agrimilure, State of South Carotina}

I am sure I experienced the same reaction to National Weights and Measures Week as the chaimen who preceded me. When the preliminaries are closed, you wonder if any steps were overlooked. If your immediate area lacked expected publicity, you wonder if that is the picture nationwide. I an quite sure this is the experience of all State chairmen and area coordinators.

I must admit the experience as chairman was rewarding. Frankly, it is too broad a progran for any one person to explore all the potentials that cam make the rampaign monch more successful. This is the point that I decided to dismuss with you, rather than emmmerate a great number of ligures as to stickers, seals, resolutions, proclamations, newspaper, and other forms of publicity.

However, I feel I should mention that all 50 states and the District of Columbia were contacted and supplied promotional material. Forty-three States reported from areage to exceptional success with their programs. 'Twenty-five eity and county jurisdictions also reported. I know there were many, many more than these 25, but these reported through their siate headquarters. 'These reports graded from the "same experience in past years" to "decided increase in public interest."

Personally, I was impressed with several new additions to the program-the small 1-inch pressme seals, the resolutions by General Assemblies, the increased use of the emblem in newspapers, and the use of the emblem by one dairy company on milk cartons that covered parts of Montana, Idaho, Oregon, and the State of Washington.

I was disappointed by some fallures at the national level which appeared sme-fire possibilities up to the last minute. Could I have concentrated on these projects, I believe one or more wonld have participated in the Week's observance.

I am sure the next national chairman will face the same problems that are still fresh in my memory. Recently I read what is known as a "smapshot sermon." It said, "A lot of good could be done in the world if nobody cared who got the credit." National WVeights and Measures Week is certainly a tremendous job, and frankly I found 
every rooperatol mole thath willing to contribute his ol hel part without any thought other than the "good of all."

We have completed four of these anmul programs. The momentum has been generited, and it is my belief that general publicity guide material is known to all State chaimen and their cooperators thronghout the individual States. Maybe we can relieve that next chaimman of deroting so much time to furnishing guide material which every one of is should have in our permanent files. If the national chairman can be relieved of a great deal of detail, he can concentrate on dereloping national publicity.

'This year the national chaimman had the help of four area cochaimen. These chairmen averaged about 13 States, and I am sure they added links in the chain to bring the State's 51 chairmen closer to national headquarters. It is a pleasure to pay respect and thanks to committee members Bill Kerlin, Fred 'True, Howard Craw ford, and 1960 national subcommittee chairman, Ellis Bowen, for a fine ball-carrying job in the backfield.

This was a modest attempt to overconte the tine elenrent involved in distributing mail on a nationwide basis. It is my belief we could increase the effectiveness of our program with a larger numer of area coordinators. I would recommend this as a consideration for the 1962 chairman.

Many observance weeks, and let me say there are many, have more active promoters in one State than we have throughout the 50 States. 'This is not sour grapes, but rather a wish that we could be equally fortunate. We have, in my estimation, a far-reaching activity which touches every man, woman, and child in this nation and throughout the entire world. Our publicity program is 4 years old, it is purely voluntary, and it has no paid publicity employees. With only a 4-year history, it is my opinion we have done a remarkable job.

According to general information, we have approximately 3,500 weights and measures officials. I have flirted with the idea that, if each of these officials would contribute $\$ 1$ to the National Conference Committee on Education, we could publish a pamphlet of wellplanned suggestions to help each official plan his promotion of the Week. Charlie 'Tooker of Rochester has given this matter quite some study and has come mp with the information that such a pamphlet could be published for about 50 cents a copy. 'This project would require some professional preparation, and the other 50 cents would corer this cost. I offer this as some future thinking for the Committee on Education and the National Conference.

I would also suggest that all of us give more attention to the yearround publicity and not depend entirely on a "once-a-year" shot in the arm." Certainly we now have the entree to local news media, and, if my State is an example, radio, TV, and newspapers welcome news from all public services. Their franchise requires that they devote a definite number of hours or space to such services.

I want to express my sincere appreciation to all who contributed to the 1961 Week. I believe many gave mustintingly of their time and efforts, though their activities never came to my personal attention. Besides self-satisfaction, I hope you are materially rewarded by the public's appreciation of your importance to equity in trade practices. 
I also want to thank industry for its continued and increasing help toward observance of the Week-the Scale Manufacturers Association and the many individual member companies, the Gasoline Pump Manufacturers Association, the American Petroleum Institute, the National Association of Dairy Equipment Mauufacturers, the Consumer Councils, and the chain and independent stores; also the National Scale Men's Association, and, right here in our own family, the Honorable L. H. Hodges, Secretary of Commerce; Dr. A. V. Astin, Director of the National Bureau of Standards; Dr. A. T. McPherson, Associate Director of the National Bureau of Standards; IV. S. Bussey, our Secretary; and Rollin Meek, our National Conference Chairman.

I want to mention one more. I deeply regret he is not here to receive our thanks. The passing of Mark Pickell of the Scale Journal lessened our ranks by one who deeply appreciated weights and measures. He gave the initial impetus to our 1961 Week with the January issue of the Scale Journal devoted to the importance of weights and measures in our daily life. It was my privilege to work with Mark Pickell on this issue, and his enthusiasm, although he was not a well man at the time, is one of the fond memories I have of an all-too-short friendship.

The program of observing Weights and Measures Week has 52 competitive weeks with a great number of overlapping competitors ryiug for top billing each week. Personally, I would welcone more national recognition to give added import to the local publicity. However, we should not concentrate all our efforts toward national recognition, because our local programs are the opportunities to introduce local officials to the public they serve.

I am convinced that the more spotlight we put on the services of weights and measures, the more diligent and intelligent we will become to perform our serrices. The more important our duties become to the public, the more important they become to the governments which the public select to administer their welfare. In gaining public appreciation, we gain govermment recognition. To gaiu both is to upgrade ourselves from the status of a jobholder to members of a recognized profession. It is equally important that our industrial associates, both in the field of providing weights and measures equipment and in consumer nuarketmg, share onr problems with each other, in order that we may move forward with mutual recognition of our allied responsibilities to the society we serve.

On behalf of the Committee on Education, I earnestly request that all of us extend to the 1962 chairman and his coordinators full cooperation in their endearor's next year toward a bigger and better observance of Weights and Measures Week in these United States.

In closing, I am grateful for the experiences of the 1961 Week. To eacb one of you here and to many others throughout the United States, I offer ny sincere thanks. To have been associated with you in promoting 1961 National Weights and Measnres Week was a privilege I shall hold dear in my memory of the tremendons impact that the National Bureau of Standards, the National Conference, and you and I contribute in serving the public.

(On motion of the committee chairman, seconded from the floor, the report of the Committee on Elucation as a whole, including the tentative report, as 
amemler by the final report, and the report of the subconmittee chairman for Nitional Weights and Measures Week, was alopted.)

\section{PACKAGE LABELING}

\section{By J. T. LiThLemeco. Chief. Foods and Standards Division, Department of Agriculture. State of Michigan}

It is certainly a pleasure for me to attend this Conference and to appear on the program. It certainly aflords all of us from across the Nation an opportunity to promote uniformity in commercial transactions.

Problems in prepackaging, as far as weights and measures are concelned. are always with us. With the progress being made in marketing and the trends toward prepackaging of just abont every item we consume, we will very likely be continually faced with new problems in weights and measures in connection with prepackaged commodities.

One of the major problems at the present time is misleading terms in comnection with the quantity declaration. The Model Law adopted by this National Conference provides:

Anr commodity in package form introduced or delivered into or receired in intrastate commerce shall bear on the outside of the package a definite, plain, and conspicuous declaration of (1) the identity of the commodity; (2) the net quantity of the contents in terms of weight, measure, or count; and (3) the name and place of business of the manufacturer, packer, or distributor: Prorided. That in connection with the declaration under clause 2, neither the qualifying term "when packaged" nor any words of similar import, nor any term qualifying a mit of weight, measule, or count (for example. "jumbo," "giant," "full," and the like) that tends to exaggelate the amount of commodity in the package, shall be nsed.

Furthermore, section 25 provides that no commodity in package form shall be so wrapped, nor shall it be in a container so made, formed, or filled, as to mislead the purchaser as to the quantity of the contents of the package, and the contents of the container shall not fall below such reasonable standard of fill as may have been prescribed for the commodity in question.

For quite some time the Foods and Standards Division in Michigan has been ritally concerned about the labeling and adrertising which attempt to mislead the public, especially as to the quantivy of contents. Furthermore, the conspicuousness of the labeling can be criticized. On many containers the declaration of contents can be found on the back of the cartons, in folds of wrappers, or almost any place where it will not be found with ease. 'The consumer must actually hunt for the declaration on many packages.

"The old saring "Caveat Emptor" (let the buyer beware) is indeed prevalent. Iíe find that some manufacturers reduce the product content without cutting the price or container size. Others apparently gire less product than specified on the package because of misleading terms which are not representative of the quantity. As a graphic example of this, consider the cartoon which appeared in various publications recently about the bewildered husband who ralked into a drugstore and asked for a small tube of toothpaste. The druggist handed him a package marked "Large."

"Trait a moment," he said, "I asked for "small"-this is 'large." 
"That's right sir," was the answer. "They come in three sizeslarge, super, and giant. Large is the smallest we have!"

This problem has dereloped orerwhelmingly since the tobacco people came ont with a king-size cigarette. 'This gimmick in advertising has caught on by leaps and bounds in other industries. We went from the "king-size" cigarette to the "long gallon" to the "long mile," and now to the "big gallon" in gasoline. Power became extra power, and extra power became super extra power. "King size" was getting small, so it became "SUPER king size." As time wore on, even "super king size" got small and became a "giant size." The quart became a full quart, a jumbo quart, and finally a giant imperial quart.

The pound is no longer an ordinary pound as we knew it years ago. It is now a full pound. It appear's that all these past years the consumer has not been getting 16 ounces to the pound. In some instances we will agree with this. And we can say the same thing about the full quart.

Small. medium, and large are becoming a thing of the past. 'The standard units of weights and measures are being warped beyond recognition. They are being camouflaged by descriptire terms which tend to deceive, mislead, and distort the actual meaning of true net weight or measure. They want the consumer to believe that my pound is bigger than your pound, and that my quart is a full quart and the other manufacturer"s is not.

'The dictionary says that to deceire is to make a person believe as true something that is false. And it further says that to mislead is to lead a person to think what is not so. It appears that manufacturers have wanted more moner for their merchandise, but they want the consumers to think they are getting more for their money. Therefore, they are both misleading and deceiving.

Adrertising agencies will admit that they found it necessary to try to outgimmick one another. but that there are still just 16 ounces to a pound. Recently we took one days local newspapers and clipped advertisements with smch misleading terms and statements. Following are examples of those taken from just one day's newspapers (one morning and one aftermoon edition):
Giant size quart
. Tumbo quart
Starter size
Full quart
Full pound
Big 2-ounce
Giant package
$1 / 3$ bigger than king size
King-size franks
I arge 52-ounce family size
Larige 21-ounce
Jumbo 24-onnce can
Giaut chocolate bars
Extra long
Tall 24-inch
Not regular 10-oz. but big 12-oz.
Hi-boy

\author{
Qucen size \\ Giant imperial quart \\ Giant size full pound \\ Full 12 ounces \\ Full 14 ounces \\ Sixteen full glasses \\ Home laundry size \\ Extra large \\ I songfellow \\ 96 ounces-that's 18 glasses \\ Huge \\ Lalrge 22-ounce size \\ Gigantic \\ Colossal \\ Big 13-oz. vacuum can \\ Two big glasses \\ Giant ecollomy size \\ King-size TV cookies
}


I law on our statute books poohibits any lalse weights ol measules, statimg that it is illegal to deliver less than the quantity represented in any commodity. Further, our weights are based on net weight, exchding wrappers and other material packed with an article. The packing referred to includes not only wrappers that maly be included with the product, bnt also the weight of the container itself and any other outside package. For example, tea bags packed in a carton-the statement of contents should deal with only the net weight of the tea in the package exchusive of the tare weight of the bags themselyes and the box container.

Another problem is the matter of drained weight in place of the total weight. An accurate method of computing such content must be utilized. A number of methods have been suggested and some LSDA and FDAl standards provide for fill of container, but in some instances the nature of the product itself may make modification of methods essential.

The object of any quantity requirement is to convey accurate information of the quantity in the package. If this purpose is accomplished, the contents may be expressed in even a conbination of terms. In the exercise of this description, however, the manufacturer must satisfy one comprehensive requirement and that is that the statement be set forth in terms generally used and understood by consumers to express quantity for that particular product.

However, such combination declarations on labels may get manufacturers into difficulty. We recently had occasion to investigate cans of pear halves. The label, in addition to declaring the contents "tl one pound, said the container held four servings, but the consumer found only two halves. A statement that certainly would not give an accurate expression of the quantity is "Fonr servings" or" "Serves four." The question immediately comes to mind, "What is an average serving?" If the can contains only four halves, then you know upon opening such a can that each consumer was to have one half. However, before opening the can, what would you consider a "serving"? If the container said "four halves" and "four selvings," and then contained only two halves, each serving wonld only be a quarter of one pear. I would still be hungry!

Statements of mumerical count should merely supplement the recognized method of designating contents; however, it would certainly be false when it is so misleading as to indicate four servings and contain only two halves.

The ordinary buyer is guided to a considerable degree by a visual appraisal of size by the comparative dimensions of a packige. Few take the trouble to read and compare quantity declatritions. Manufacturers appear to be capitalizing on this knowledge of consumens' purchasing habits by utilizing containers which apparently enhance the size and hence the value of the commodity. 'Talie soap and detergent packages as an example. Some may have a large container, but within that container there may be a gift which doubtless has been figured in the cost, and although the consumer is buying this product and perhaps paying a higher price, she feels she is getting the lirgest size.

WVe recently made a survey on the weights and prices of soaps and detergents. Fifteen brands were compared-the dechared weight 
against the net weight, the unit price, and the price per pound. Note was made as to whether any gifts were included and the location of the reight declaration. All the packages were labeled "giant" except two. All were labeled in rarious ways, and had identical height and width, but varying depths. None had the contents declaration on the front panel. Nine of fifteen had fractional ounces in the net weight. 'The highest cost per' pound was 87.3 percent more than the lowest.

At the 1955 National Conference, the Committee on Methods of Sale of Commodities reported that such terms as jumbo, king size, Texas pint, and others were subtle in their intent for what psychological effect they may have. Designations of this kind are quite in the same category as the use of such terms as "full pound," which often appears in advertisements of certain types of vendors merchandising such items as cakes, candy, and potato chips. Tebster's dictionary defines the adjective word "jumbo" as "huge of its lind." Obriously you cannot have a huge standard measure container. Such containers either hold their declared rated capacity within the tolerances permitted or they are not correctly marked.

While on the subject of potato chips and the subject of the confused housewife, it might be well to bring mp the subject of the full pound as encountered by onr State in the metropolitan area of Detroit. On a project in conjunction with the city reights and measures division, we ran head on into the use of "full pound" on potato chips. 'To begin, it would be well to relate the source of the problem to further understand the mamer in which this problem grew.

The potato chip industry in Michigan is dependent upon our local potatoes to furnish the bulk of the raw material. However, as this supply vanishes, the industry must seek other sources. They begin by buying southern potatoes and follow the crops up as the warmer weather comes north. 'They have also begun to purchase potatoes in the West. From an economical standpoint, the price of potato chips is lower when they use Michigan potatoes at about $\$ 2$ a hundred pounds. Howerer, when they are using southern potatoes at $\$ S$ or $\$ 9$ a hundred, including shipping, they must alter the size of packages and prices of their products.

'They have solved this problem by leaving the bag without a weight declaration. They use what is termed a saddle similar to an overlabel. On these saddles they mark the weights and prices and staple them to the top of the packages. The saddles are printed locally or can be obtained rery easily on short notice. 'Therefore, when sonte of the competition comes up with an adjective to describe the contents, such as "full pound," the remaining companies fall in line to maintain their sales, or they might even go the competition one better. as one company did, and have saddles printed stating "Giant Size Full Pound, 596 Pound," "Giant Size Full Pound, 69\& Pound," and "Giant Size Full Pound, T9\% Pound." He was ready for any and all challengers.

'This problem is not confined to the potato chip industry, however, as the nse of the term "full pound" is now to be found in the sansage industry. "The term "full pound" was found on packages manufactured by various sansage dealers in the area. Their point was that so many of their competitors had begun packaging a 12- and 14- 
ounce package of the various luncheon meats and sausage products, they should get their point across to the shopper that theirs contained one pound of product rather than the smaller amount of 12 or 14 ounces. Therefore, they felt the term "full pound" was just $\mathrm{i}$ fied. The next logical step in this type labeling would be for the competition to label theirs as "full 12 ounces" or "full 14 ounces."

Other items include cookies. Tre now have a "king-size TV cookie." The question is whether it is a "king-size cookie" or a cookie to eat while watching a "king-size TV program."

'The products mentioned are not necessarily the only ones that are described with such misleading and deceptive terms, nor will they be the last. The problem now is, Where can the line be drawn and what is the solution?

Almost six rears have passed and we have not been successful in stamping out these misleading terms in promoting the sale of various commodities. This trpe of mislepresentation is not confined to Michigan. as I stated before-this is a nationwide problem. I think we should all support the action of previous National Conferences and take immediate action to prevent the continuance of such misleading labeling and adrertising. We should voice our objections to the misuse of such terms wherever possible. As a purposeful organization meeting here this reek, I urge that we mify ourselves and leave this Conference with the full intent and purpose of stamping out the use of such misleading terms on a national scale. The time for action is now. There is deceptive packaging, we know, and too much of it. This evil will not depart automatically. Someone has to dispel it, as Food and Drug Packaging stated early this year. This magazine is to be complimented for the statements on the vital problem of deception in its January 5, 1961, edition, which read:

Packagers must police themselves as well as they can or risk Goverument control, which would lean heavily toward packaging standardization. What is needed is a bold approach to the problem-organization of a dynamic, fearless packaging association willing to stand up to outside interference, unafraid to slap its own members down when they breach business ethics or propriety. This must be done in 1961 to preserve the independence, growth, indiriduality, and full marketing value of packaging.

It is not only deception in the advertising gimmicks which attempts to whiterash cousumers, but other means such as slack-filled packages. The recent Federal case on "slack-filled" packages of mints has been in the news for some time. The reopening of this case has brought about the question again as to what the term "slack package" means under the FDC Act. The case involved the FDA charge that the manufacturer was using cushioning material and headspace to produce an elongated container which misled consumers into the belief that they were purchasing more mints than the package actually contained. The manufacturer contended this was necessary to protect the product.

The labeling must be honest. Some relatively unimportant factor cannot be played up in big type, while more vital factors are relegated. Magnificent product illustration, commendable graphic design, brand and product name. instructions for use, and opening directions seem to place the net contents declaration into obscurity.

A Michigan firm recently packaged "individual martinis." Each drink was carefully mixed, embellished with an olive, covered with a 
special plastic wrap, sealed to be spillproof, and then placed in a printed box with a styrofoam form to fit the shape of the cocktail glass. It will become a bartender's nightmare if this idea gains popularity. I wonder about the weights and measures official's task in checking the contents of such a commodity without opening the iuside package! 'There was no contents declared except one martini, and how are we to tell if the glass holds 3 or 4 omnces?

In September 1960 I forwarded to all weights and measures officials in the United States copies of my correspondence with the Federal Alcohol Tax Division regarding the use of snch terms as "king size," "giant," and "big" in conmection with the contents and asked each jurisdiction to notify me if any action had been taken to prevent snch misleading labeling and advertising. Replies were received from 10 States, 1 comty, and 2 city jurisdictions. The replies would indicate that the nationwide sentiment is toward elimination of such advertising and labeling practices. Following are brief extracts from the replies:

... only plagued witl "full pound" on haked goouls. Prompt action eliminated this condition and prevented spread of such terms. In recent years have attained enough notoriety to attract attention of printers and lithographers. With their interest in protecting accounts, they lave also disseminated proper information to their clients.

... We, too, are quite interested in deceptive marking of prepackaged prodnets. Our laws skirt the subject as to infer we may have the powers now but legil minds adrise that we spell out these laws, if and when both personuel and travel appropriations are provided.

We are also interested in finding some way to attempt to stop labeling and adrertising which is misleading to the public, but so far we have not made mich progiess.

We certainly isree with you that labeling commodities in terms of "king size," "big." "giant," and similar statements is in violation of the intention of State laws and action taken by the National Conference... We have done some work . . to discourage this practice; however, at the present time we do not have sufficient law to correct it entirely. We will continue to discourage qualifying statements of weight contents so far as we are permitter moler our present law.

I agree with the statements. I shall be rery glad to assist you in this Pirlearror.

Wholeheartedly approye and congratulate you on your action and accomplishments in the instances where you have stopped these practices.

. As a result of rour letter... I made a field trip to survey the labeling which you mentioned ... As a result of my fiudiugs, I have written to the offenders. . . I feel a concerted effort by a nmmber of States will bring results. Be assured we are willing to conperate to the extent that our personhe] and man lours will peruit.

We have recontly established a package-control division and are very active in the control of all our parkages.

I do not kuow of aur problem that faces weights and measures that would he more destructive than this one. I am wholeheartedly in agreement with you that there should be unified action in regard to this subject on all commodities sold by weight and measure, particularly in the food field.

.. I fully agree that the use of such terms is an attempt to mislead the buying public into believing it is receiving more than it does. For this reason, sone definite action should be taken to bring about a discontinuance of the practice. 
Oux department is new; therefore, we have not as yet delved too much into the misrepresentations and malpractices of advertising. I am sure the points brought out in sour letter have merit, but I would refrain from making comments at the present time.

. The use of such terms . . has beell considered, to some extent, by nur department. Our attorney feels that the use of these terms is not a direct riolation of our weights and measures law. We all feel that, to some extent, it is deceptive and that the terms should not be used, but our attorney feels we would hare a nearly hopeless case under our laws to stop the use of them. We have been so busy stopping direct and unmistakable violations of the law that we have not thought it worthwhile to go into such a matter as this unless we had a law that directly prohibited such terms. We sympathize with what you are trying to do and hope you are successful.

We are statewide in operation and would like to say that over 60 percent of our time is deroted to keeping down violations of labeling and short weight to a very low minimum.

To accomplish the objectives of the action officially adopted by this National Conference in previous years, I feel weights and measures officials throughont the Nation should do whatever they can within their respective jurisdictions to promote nniformity by bringing about the successful conclusion of any action adopted by members of the Conference. Of course, I realize that there is the problem of some local ordinances, regulations, or laws preventing action in a particular jurisdiction, but I definitely feel that Conference action should be given full consideration by all persons in permissive jurisdictions.

If necessary, I would urge that the Conference restate the position taken in previous years as a means of emphasizing the intent to eliminate misleading terms in advertising and labeling which practically result in deceptive packaging.

There is room for great improvement in package labeling. The significance of the words "conspicuously labeled" seems to have been lost in the maze of product promotion to a point the consumers can no longer easity determine how much of a given commodity they are purchasing.

The sincerely appreciate the continued cooperation we receive from officials in other States and assure you that we will continue to do our utmost to serve the people of our State and to protect the interests of all persons or firms doing business within our boundaries.

I close with this thought. There is not a job in the world that cannot be done better than it is being done. A man is not doing the best he can for the agency that employs him, the people he serves, or for the world if he goes through life without looking for that better way.

\section{DISCUSGION ON FOREgOING PAPER}

Mr. Bower: I would like to commend Mr. Littlefield for what I ronsider a very able presentation of this troublesome problem that we face today. I was particularly interested in his suggestion that we as individuals can do something about it, and I think that we can. Public opinion is quite a powerful force. We are in a very adrantageous position to nudge public opinion. In Massachusetts we have done a little along this line.

Several months ago I wrote a letter to the local editors about this problem. One of the local editors was impressed enough that he said, instead of using it as a letter to the editor, he would like to 
make a special feature out of the letter and he played it up on the front page of the newspaper.

IVe have been hearing about the pumping of hams. So I got busy again and wrote more letters to editors about this matter, sugresting that anyone could oppose this proposition by writing to the U.S. Department of Agriculture. I was very fortunate, I think. in that one of the newspapers that used this material was the Christian Science Monitor, which has a national circulation, and I was pleased to receive a comment from a lady in Pasadena, Califormia, 3,000 miles a way.

Mr. Bivcon: You mentioned in your statement the matter of reasonable fill. That word "reasonable" is very difficult to define. Just before I left home, I received several complaints about reasonable fill. I would like to see more specific terms used in legal documents.

Mr. Matt Jennings: For quite a number of years I have observed and have been very much impressed by the efficient regulatory control you have in Michigan. I was interested in one particular statement and that was that, after 6 years of effort, your are still unsuccessful in your dealings with misleading terms.

In your experience in dealing with this problem, what would you consider to be the major handicap-ineffective legislation, insufficient coordination of enforcement among city, county, and State officials, or possibly the merchandising gimmicks and practices that may be ontside the realn of present legislation?

Mr. LitTleweld : I think, Mr. Jemnings, you have answered your own questions in the order of their importance in our problem.

Mr. Christie: I would like to ask yon to answer two questions. In your research have you come across any State that has standards other than those furnished or recognized by the United States? And what kind of cooperation has been received by your organization in doing away with snch labeling when you bring it to the attention of the packer?

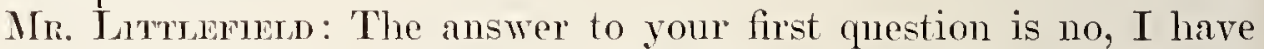
not. 'The answer to your second question is, basically we have had very excellent cooperation, with the exception of the alcoholic beverage industry, particularly malt beverages. Our problem is that so many of the packages are in interstate commerce. They may originate clear across the country from us, and when we attempt to bring abont corrective actions the packers wonder why their own State or local jurisdiction did not say something about it. This was the case of the corn which I mentioned in my formal comments.

Mr. Stender: In the last sererial weeks we have had some manufacturers bring in their packages and ask whether or not we would approve them. They were slack-filled, and in our discussions we asked the question if this was the desire of the mannfacturer or whether that was the idea of the advertising concern that handles their advertising. My question is, do you think that these slackfilled packages and deceptive packages are actually a real desire on the part of the manufactmrer or do you think or have you found that the advertising companies are probably promoting the idea rather than the manufacturer himself?

Mr. LtTruernen: First, Mr. Stender, I did not go into this in great detail. I think there is a combination of factors here on the 
part of both mamufacturer and packager. It has been said that you lo not sell commodities, you sell packages. 'This bothers us some. But I think there is a combination of factor's involving both the packiger and the advertiser.

\section{PROGRESS IN THE MIEASUREMENT OF MOISTURE IN GRAIN}

\section{By W. W. Walton, Chief, and W. C. Wolfe, Chemist, Organic Building} Materials Section, Building Research Division, National Bureau of Standards

The amount of moisture in grain is important for two reasons. First, the price of grain of a given quality is directly related to the moisture content, and second, the deterioration of grain in storage is dependent, principally, upon the moisture content, although other factors are important. The major interest of this group is the first reason, the moisture-price relationship.

Why is the determination of moisture in grain such a difficult problem? One important reason is simply that only a few people are willing to spend the time necessary to obtain an accurate result. There is a more basic reason, however, and it can be illustrated by a simple example. Calcium sulfate may exist in the anhydrous state or with two molecules of calcium sulfate combined with one molecule of water or with one molecule of calcium sulfate combined with two molecules of water. TVe commonly refer to the latter two as Plasterof-Paris and gypsum, respectively. We cannot properly speak of the gypsum as being diluted with water, because the material is not gypsum unless it has the two molecules of water present. This is a sinple case, because we have a single substance, calcium sulfate, combined with water.

Grain, on the other hand, is not a single substance, but a complex mixture of proteins, carbohydrates, oils, mineral matter, and other substances. Each of these materials, such as proteins or carbohydrates, are in themselves mixtures and not single substances. And finally, even a single pure protein has a very complicated structure compared to calcium sulfate. The colloidal nature of these materials makes it very difficult, if not impossible, to differentiate between true moisture and water that is actually a part of the structure of the grain.

Mother Nature adds one more artistic touch to this complex picture-some of these materials are unstable and yield water as one of the products of decomposition.

The ideal solution of the problem would be to determine the amount of water that is part of the structure of the grain and correct the determination of total water for it. Unfortunately, the possibility of doing this is far off in the future. It is an extremely difficult problem to solve.

Another method of solving the problem is to obtain general agreement on what shall be considered moisture. The Department of Agriculture has done outstanding work in this field and their oven methods for grain are specified in the Official Grain Standards of the United States. These oven methods have been reinforced by more recent work of the Department of Agriculture and others. The moisture in the grain is extracted with solvent and the amount of 
water in the solvent determined by titration with Karl Fischer reagent. These results are used to confirm those obtained by oven methods or may provide a basis for changing the oven methods. Oven methods yield reproducible results when the standard procedmres are followed precisely, but they are not too satisfactory for field use.

A great many workers have been trying to develop more rapid methods that would be satisfactory for field use. It wonld probably require several days to discuss all of these methods, and it is doubtful that such discussion would be very profitable.

Methods for the determination of moisture vary in principle from something as old-fashioned as the acetylene lamp to something as modern as radar. Calcium carbide reacts with moisture to yield a gas, acetylene, and the moistme content may be determined by measmring the amonnt of acetylene formed. Loss in weight or the pressure developed in a closed system may be used to obtain the amount of acetylene. With respect to radar, it was noted in early work with radar that signal strength was greatly reduced at times. The cause was traced to high humidity of the atmosphere. If microwaves (radar) are allowed to pass through a material such as grain, the energy loss is related to the amomt of moistmre in the grain. Measurement of the loss of energy with dry grain and with grain containing varing known amonnts of water establishes a relationship which can be used to determine the moisture content of unknown samples.

With this background information in mind, a discussion of the work at the National Burean of Standards shonld be more meaningful. 'The derelopment of an instrmment that will sell for $\$ 50$ that can be operated by a kindergarten student and give accurate results on all types of grain does not appear to be imminent. It is hoped, however, that a method an be developed that will yield accurate results in the field with a reasonable consmmption of time and requiring only a moderate amonnt of practice to become expert in its use.

One of the methods inrestigated at the Burean is nuclear magnetic resonnnce. 'This is a rather complicated concept, but it is based essentially on the fact that the hydrogen nuclens, the proton, as well as miny other atomic nnclei, possess an intrinsic angnlar nomentum or spin. If the material is placed in a magnetic field, the energyexchange properties related to this angular spin may be investigated. These properties depend upon the other atoms with which the proton is associated; that is, hydrogen present in paraffin can be distingnished from hydrogen present in water. In fact, hydrogen present in free water can be distinguished from hydrogen present in strongly adsorbed water.

This method offers more promise as a research fool than as a practical field method. It is being investigaled because the information obtained nay be helpful in the evaluation of other methods. Preliminary studies with wheat enabled samples of known noistmre contents to be an'anged in the order of their noistme content and duplicate samples to be identified as duplicates. More detailed studies are being planmed for future work.

'The cost of equipment for measming muclear magnetic resonance 
is high. I balnain instrument has recently been placed on the market at $\$ 23,950$. However, an instrument designed for measuring moisture in starch is priced at approximately $\$ 15,000$. The instruments are also very heary and large, and their use requires considerable training.

An example of the importance of this technique in research is some recent work done in London. The amomnt of water present in the hydration shell of proteins was mensmed in a water solution. The two types of water could be distinguished.

Another technique that has been considered by the Bureau is the use of tritium, the radioactive isotope of hydrogen. If a known imount of tritiated water were shaken with a known weight of grain, the tritiated water would be diluted by the moisture in the grain. The measurement of the concentration of tritium is a simple matter, and hence the amount of dihtion could be determined. The amount of moisture in the grain could be readily calculated.

Unfortunately, calculations have shown that present methods for the determination of tritium do not have the accmacy that would be required to make this method applicable to the main problem. It does seem possible that the method may have some research use in studying the nature of moisture in grain. I definite time would be lequired for free water in grain to cone to equilibrium with the tritiated water, and it seems plausible to reason that more tightly bound water would require a longer time. A study of the rate of dilution under controlled conditions should yield valuable information about the physical state of the water in the grain.

There is presently available a simple automatic device for the determination of chloride, so the substitution of a sodium chloride solution for the tritiated water suggested itself. A known amount of a solution of sodium chloride when shaken with a known weight of grain would be diluted by the moisture in the grain. Titration with the automatic titrator would indicate the amount of dilution and the percentage of moisture in the grain could be calculated. Preliminary calculations indicated that the accuracy of the chloride titrator was high enough to make the method feasible.

$\Delta$ few experiments were tried with samples of wheat, but equilibrium could not be established. The salt solution became more saturated instead of more dilute. Apparently the grain was adsorbing water from the solution. The chloride ion present in the grain itself was too low to liave any measurable effect with the salt concentrations that were used in these experiments.

Another method that was considered by the Bureau is based on bombardment of the grain with fast neutrons. These fast or highenergy neutrons have their energy reduced by collision with atomic nuclei and become slow or thermal neutrons. Hydrogen nuclei are so much more effective than other nuclei that this conversion of fast to slow neutrons can be used to determine the number of hydrogen nuclei that are present. In practice, a fast neutron source and a detector sensitive only to slow neutrons are placed in the material. 'The distance between the source and detector and the geometry of the container holding the material are both important.

The method has been used not only to measure the amount of water in foundry sand, but to control it through auxiliary equip- 
ment. An intriguing aspect of the method is that it would be applicable to large volumes of material such as contained in a carload or a grain elevator.

There is one major difficulty. As mentioned earlier, the effect depends upon hydrogen nuclei, and it is the same regardless of whether the hydrogen nuclei are present in the form of water or any compound of hydrogen. 'There is no problem with sand, because practically all of the hydrogen is usually present in the form of water. 'This is not true for grain. Large amounts of hydrogen are present in the form of proteins, carbohydrates, and oils. No practical solution to this difficulty has been found.

As mentioned earlier, the Department of Agriculture has determined moisture in grain by extracting the water with a solvent and measuring the amount of water in the solvent by titration with Karl Fischer reagent. The chief difficulty arises from the titration. A person with considerable training and technique is required to perform the titration accurately.

The Burean is giving considerable attention to an extraction method. The presence of water in a solvent changes the physical properties of the solvent and the amount of change may be used to measure the amount of water present. Refractive index, density, dielectric constant, and conductivity are some of the properties that vary with the concentration of water. Measurement of one of these properties would eliminate the necessity for titration.

The method can be divided into three parts, comminution of the sample, the choice of solvent, and the technique for determination of the water in the extract. With respect to the first part, comminution of the sample, a Stein mill is being used to grind the material in the presence of the solvent. This apparatus was found to be satisfactory in the work of the Department of Agriculture. A few experiments have been carried out with the Waring blendor and the results warrant additional work.

'The choice of solvent depends upon a number of factors, but the most important ones are the ability to extract moisture from the grain and the physical property that is being used for the determination of the water content of the solvent. For example, if refractive index is to be used, the solvent should have a refractive index that differs from that of water sufliciently to make the determination of water as accurate as required. Methanol, dioxane, dimethyl formamide, dimethyl sulfoxide, and acetone are some of the solvents that are being considered. Dioxane is particularly suited for a dielectric method of determining water content, because it has a dielectric constant of less than 3 compared to a value of 80 for water.

The third part of the extraction method is the determination of the water content of the extract. A few measurements of refractive index of water-dioxane mixtures were made on two differential refractometers that were built at the Bureau. Creeping of the liquid produced erratic results with one of the instruments, but satisfactory values were obtained by the second instrument.

Both refractive index and density methods for determining the water content of the extract require very close temperature control of the liquid and it was decided to investigate the measurement of dielectric constant of the extract. 
Inasmuch as equipment suitable for this particular use is not arailable, it was necessary to design such equipment. 'The first problem was the construction of a cell that would hold the liquid. 1 twin cell was designed to permit rapid comparison of the dielectrie constant of the solvent and the extract. The cells are surrounded with a common jacket to permit circulation of water when temperature control is required. Special coaxial switches were built to aroid changes in calpacitance as the switches are used.

Careful measurements with this cell disclosed that air bubbles were being retained under the base of the inner core of the cell. To aroid this difficulty, the base was enclosed with an epoxy resin. The epoxy resin eliminated the air bubbles, but it is causing the cell to show a small drift in capacitance. The cell is being modified by using cyinders with a conical base for the inner core, and this will eliminate the bubbles and the need for the epoxy resin.

Measurements with this cell hare been made using a transformer bridge and a $Q$ meter, but both of these instruments are complicated and difficult to use. A simpler commercial instrument was found to be too unstable for this use.

Recently, a sensitive and stable capacitance meter circuit has been developed in Japan. The circuit is comparatively simple and can be adapted to the cell described above. An instrument is now under construction for the Bureau.

Then this equipment is arailable, a thorough study will be made of the factors affecting the results, such as grinding, solvent, temperature, etc., and how closely these factors must be controlled to yield results of the desired accuracy.

Although a large amount of work remains to be done, it is hoped that this research will lead to a method that you will find helpful in your work.

\section{INTRODUCTION OF MR. J. R. ROBERTS BY W. S. BUSSEY, SECRETARY}

The opportunity of introducing the next speaker is a personal privilege for me. I had the pleasure of attending the annual conference of the British Institute of Weights and Measures Administration in 1956 and again in 1960. In 1959 I was elected a vice president of the Institute, which I understand is the first and only time that this honor has been bestowed upon any person outside Great Britain. I appreciate that honor and I know that all weights and measures officials in this country appreciate it, also.

Our speaker has spent several weeks in this country prior to this Conference. He has visited with many of you and you have gotten well acquainted with him and with his charming wife. Therefore, to many of you he needs no introduction, and I am sure that before he finishes his assignment and leaves the confines of the United States, the remainder of this group will need no future introduction.

Our speaker is a career weights and measures official. He actually entered weights and measures service in the City of Chester, England, at the age of 16 years, as a pupil-assistant. In 1928 he passed the Board of Trade examination, which is required for all weights and measures inspectors in Great Britain. In 1929 he became an inspector in the city of Chester after having received this appointment. In 1930 he was appointed inspector in Cheshire County by 
the Cheshive County Council. He next served as district inspector, deputy chief inspector, and chief inspector of Northumberland County from 1935 until 1946.

He became Chief Inspector for the City of Manchester, England, in 1946, which position he holds at this time. He was elected to the Council of the Institute of Weights and Measures Administration in 1947. He was elected as Issistant Secretary of the Institute in 1951, and was elevated to the oflice of Secretary of the Institute in 1953, and he continues to fill that important position.

Our speaker received a diploma in public administration from the University of Durham. He is a Fellow of the Tustitute of Weights and Measures Administration in England. As I stated in the beginning, he is a career weights and measures official, if there ever was one. He is one of the most devoted persons to the weights and measures cause that it has ever been my privilege to meet and to know.

This is the first time that the British Institute has authorized one of its members or officers to attend a weights and measures conference outside Great Britain, as the official delegate of the Institute. I consider that we are signally honored by being chosen as the weights and measures organization that would receive this official delegate for the first time.

It is with a great personal pleasure, that I would introduce to you at this time, my personil friend, Mr. J. R. Roberts of Great Britain, Chief Inspector of Weights and Measures for the city of Manchester. and Secretary of the Institute of Weights and Measures Administration, Mr. Roberts.

\section{TRAINING OF THE WEIGHTS AND MEASURES OFFICIAL IN GREAT BRITAIN}

By .J. R. Robmiss, Ionorary Secretary of the Institute of Weights and Measures Administration, and Chief Inspector of Weights and Measures, Manchester, England.

\section{Introductory}

'The inspector of weights and measures in the United Kingdom is a local govermment officer, employed in England and Wales either by a county council or a municipal borough; in Scotand by a city, a connty, a burgh, or a joint authority. Under whatever type of anthority he works, the inspector is unique in the local government service in that he holds a certificate of qualification issued by the Central Government and also that he is privileged to use as part of his official stamp of verification the Royal cypher bearing the initials of the reigning Sovereign. Moreover, he enforces Acts of Parliament and Regulations which are uniform throughout the country and he works in close association with the Board of Trade, the department of State responsible for the general coordination of an effective weights and measures service.

Since 1889 the law has decreed that no person may act as an inspector of weights and measures unless he has passed an examination conducted by the Board of Trade and has been granted a certificate by that department of Government. The provisions were 
riried slightly in 1904, and the existing procedure, whereby a person cannot sit the Board of Trade Examination unless nominated to do so by a local authority, and the terms of the qualification of an inspector are as set out in section 8 of the Treights and Measmres Ict, 1904, the full text of which is as follows:

1. The Board of Trate shall provide for the holding of examinations for the purpose of ascertaining whet her applicants for the post of inspector under a local authority nominated by that authority possess sufficient practical knowlelge for the proper performance of the duties of inspectors of weights and measures, and for the grant of certificates to persons who satisfactorily pass such examiuations.

2. I person shall not be appointed to act as an inspector of weights and measures unless he has obtained such a certificate as aforesaid.

3. If any person not being an inspector duly appointed under the Weights and Measures Acts, acts as such inspector he shall be liable to a fine not exceeding 10 pounds, or in the case of a second or subsequent offence, twenty pounds.

In the Meights and Measures Bill now before Parliament, the maximum penalties proposed for anyone acting as an inspector who is not qualified and duly appointed are $£ 100$ for a first offence, $£ 250$ for a second or subsequent offence, or to a term of imprisonment not exceeding three months, or both.

In the 72 years existence of the Board of Trade Examination, 7,471 candidates have sat, of whom 2,864 or 38 percent passed. At present there are in the region of 850 practising inspectors, or roughly one to every 60,000 of the population of the United Kingdom.

The system of appointment being contingent upon success in a specialist and competitive examination has evolved a well-trained and efficient service. There are approximately 250 weights and measures authorities of widely varying sizes and densities of population, but in every one there are employed full-time officials with the same basic qualification and with the same statutory responsibilities and duties. Tithin the long established tradition of enforcement at local level, there is therefore the underlying effect of uniformity of purpose and action, and despite occasional suggestions that the service should be fully centralised, it is evident that weights and measures administration will remain a function of the local authorities. The new Treights and Measures Bill suggests that there will be some changes in the actual units of administration, dependent upon the status and popnlation of an area, but the general effect will be an increase in the number of local anthorities empowered to appoint inspectors of weights and measures.

\section{Prestige and Remuneration of the Weights and Measures Service}

The weights and measures department of a local authority is a comparatively small one, bnt nevertheless it is recognised as being extremely important to the well being of the community, and it is likely that its prestige will increase with added duties and responsibilities envisaged by the legislation now before Parliament. Apart from purely weights and measures duties, many local authorities call upon their inspectors to administer other statutes of a public protective nature, such as those relating to food and drugs, petroleum and explosives, merchandise marks and fertilisers and animal feed- 
ing stuffs. With the ever-widening interest in all aspects of consumer protection, it seems likely that still more duties will derolve upon the weights and measures departments, which indeed provide a ready-made service of trained personnel fully equipped technically and legally to undertake this class of protective legislation.

In common with all branches of the local government service in Great Britain today, the weights and measures departments are experiencing a period of difficulty in attracting a sufficient number of junior entrants of the right type. This is particularly noticeable in the urban areas and is perhaps symptomatic of the period of full employment when the civil and local government services have to compete with the better pay and prospects offered by commerce and industry. Certainly remuneration in the weights and measures service is not large by modern standards, although much progress has been made in the postwar years, and efforts are continually being made by the staff associations to ensure that salaries do not lag too far behind those merited by the importance of the service and those paid in other professions.

The Institute of Weights and Measures Administration is a professional body and by its constitution is debaned from engaging in salaries and service conditions activities. Nevertheless its aims and objects are directed towards enhancing the dignity and prestige of its nembers and must have some bearing on the standing of the inspector of weights and measures in his community.

Most inspector's and their assistants belong to the National and Local Government Officers Association, which, with its membership of 274,000, exerts a powerful influence in its trade mnion, but nonpolitical, activities. 'There are also two other bodies, the Association of Inspectors of Weights and Measures and the Society of Chief Inspectors of Treights and Measures, which look after the material interests of the qualified persomnel.

Salaries in the local government service in Britain are negotiated and fixed on a national basis, and there exists elaborate machinery whereby employers and employees get together to arrive at grading schemes which are generally applicable throughout the conntry. Separate Joint Comncils exist at the present time for England and Wales and for Scotland. Apart from salary scales, these bodies determine conditions of service such as leave entitlement, sickness payments, financial assistance for post-entry training, and many other matters affecting the welfare of the officer. All posts are, of course, superannuable on a contributary basis.

At the time of writing, a junior entrant to the local government service in Enoland and Wales has a salary scale in the General Division of $£ 220$ at age 16 , rising to $\$ 455$ at age 22 , with extended increments up to a maximum of $£ 690$ per anmum. 'There are other Divisions, such as Clerical or Miscellaneous, appropriate for the unqualified officer according to his duties and responsibilities, with salaries ranging from $\& 450$ to $\$ 215$. So fin as inspector's of weights and measures are concemed, there is a special basic scile for a newly qualified officer commencing at $\$ 745$ and rising by anmmal increments in five years to $£ 960$. Salaries for the higher posts, such as district, divisional, deputy chief, and chief inspectors, are at the discretion of the local anthority, and there is inevitably some lack of mi- 
formity thronghont the conntry dependent somewhat upon the size and, may one sily, the generosity of the local anthority.

Veedless to siy, the varioms statf' associations have as their goal the establishment not only of gencrally improved rates of pay, but of national scales applicable to all grades of inspectorship.

It is of interest to note that in the Weights and Measures Bill currently before the Hons of Conmons the designations "chief inspector of weights and measmes" and "deputy chief inspector of reights and measures" are given oflicial recognition for the first time. In the existing legislation all references are only to "inspector" and the titles of the senior posts have only become common by administrative convenience and long usage. Under the Bill every weights and measures authority must appoint a chief inspector and may appoint a deputy who can carry out the dnties of his chief whenever necessary. 'This new statntory recognition is of course accompanied by many additional responsibilities and must lead to added prestige iil our jrofession.

So far the weights and measures service in Britain is an all-male preserve, except for clerical posts, but there is nothing either in present or prospective legislation to prevent a woman becoming an inspector of weights and measures. There are certain aspects of the work which would be suitable for the opposite sex, particularly if we extend further into the consumer protection field, and the day may not be far distant when our departments may be the brighter for some feminine influence.

\section{Recruitment}

Methods of recruitment to the reights and measures service vary to some degree between the different local authorities, but they all have the same end - to secure, or to endeavour to secure, the entrant who will fulfill the qualities needed to make a good inspector. 'There are many inspectors practising today who have come from different walks of life, but none who have not had to devote a period of intense and fairly lengthy study for the Board of Trade Examination and to practical training in a weights and measures office. It is impossible nowadays for anyone to obtain qualification without having spent some time beforehand actually on the job under the guidance of experienced inspectors.

The most faroured method of recruitment today, and the one most likely to produce the best results, is to engage the embryo inspector straight from school at age 16,17, or 18 years. This is effected in different ways. The larger authorities have a junior entrants examination open to all who favour a career in local government. The successful candidates form a pool from which the different departments of the local authority can make their selection. Often explanatory talks are given to school leavers to help them to choose the work for which they feel they have interest and aptitude. It is unlikely that many boys while still at school have any ideas about making a career in weights and measures, and this is one of the services that has to be sold to them. A useful way of doing this is to encourage group visits of youngsters nearing school-leaving age to the weights and measures department when the attractions of a job which does not involve being tied to a desk all one's life can be explained. 
Selection boards operate in some areas, juniors being interviewed, their capabilities and school recorels being assessed, and the work of the anthority explained so that they can themselves give some indication of preference. There has also been established a Local Government Entrance Examination which is conducted on a regional basis. 'This obviates the need for local authorities to concluct their own examinations and opens the door to employment in any one of the several authorities in the same area.

Yet another method of recruiting the junior entrant is solely on the results of his school-leaving examination. 'The General Certificate of Education with passes in at least four subjects is usually acceptable. Obviously some leaning towards the technical subjects is desirable, and passes in Mathematics and English essential.

Although recruitment direct from school is probably the best, this is not by any means the only method of entry to the weights and measures service. Officers can transfer from one department to another within a local anthority, and there is recruitment from ontside local government hy means of public advertisement. 'The latter method is probably more favoured when the officer required is not one who is primairily intended to become an inspector, but rather needed for the mechanical or clerical work of the department.

At one time the weights and measures department frequently had some connection with the police force, but this is now almost entirely extinct. To the writer's knowledge there is only one local authority in the country where there is now any direct comnection between the two branches of enforcement. Fven here the inspector's and assistants have for several years been recruited from civilian sources and a process of thange is well on the way to completion. Men who had sone early police traming have proved to be excellent inspectors of weights and measures, but it is recognised that weights and measures administration today is a highly specialised field for which extensive traning in of her than enforcencent activities is required. 'The police authorities are relieved of the extraneous duties and, althongh there is close and friendly liaison whenever found necessary, the weights and nueasures department is today an entively separate civilian olganisation, usually headed by a chief inspector diuectly responsible to the local anthority.

Another somce of recruitument in the past has been from the scale industry, but this is of comparatively rare occurrence nowadays. Men with specialised knowledge of weighing instruments are certainly an asset, but more than this is required of an inspector, and the inechanic seldom feels inclined to go back to school and stant sudying for the theoretionl subjects of the examination. Again there is the friendliest cooperation between the industry and the inspectorate accompanied by a nmtual recognition that in nost respects their interests ane ontirely distinct.

Whicherer method of rerruitment is followed, there is no donbt. that the most important stage is the personal interview before engagement. 'This is alried ont by a senior oflicer of the department, the chief inspector or his deputy. On the selection of the new entrant, the future of the service depends, and the most careful enquiry needs to be made not only into the candidate's educational background but into his chanacter, mental and physical alertness, appear- 
ance and general aptitude for the job. At this interview the prospects in the way of pay, promotion, and service conditions are explained, and the candidate left in no doubt that hard work and intensive study are his lot if he wants to make any headway. Qualification as an inspector is the goal at which lye must am. If he does not sncceed in this, he will have no future in weights and measures other than acting as an assistant in the routine mechanical or clerical duties. He must also be told that, even after he has qualified, he will only be starting to learn and that continuing application will be necessary to keep abreast of changes in the administrative, technical. and legislative aspects of his chosen career.

\section{Training of the New Entrant}

There is at the moment no age limit for entry to the Board of Trade Fxamination, but it is proposed by the Weights and Measures Bill that no certificate will be granted before age 21 years. Cases are known where there have been successes before this age, but in general an assistant is usually turned 21 before he sits, and for the jumior entrant this enables a period of three to five years to be spent in preparation for the examination. As long a period as possible should be allowed for any student to obtain a thorongh grasp of the work and to complete the various studies in good time. Five years preparatory work is not too long to cover the scope of the present syllabus.

On first entry the student will probably spend most of his time on clerical duties, thereby familiarising himself with the routine of the office, the records which have to be kept, and generally obtaining knowledge of the functions of the department. He will be enconraged to get to know the various types of standard and traders' equipment handled in the department. Later he will take part in the various processes of testing weighing and measuring equipment. In many offices the adjustment of traders' weights and measures is carried out, and in this he will participate nnder the supervision and guidance of senior officers. Although the duties of rerification and inspection can only be carried out by a qualified inspector, the inspector who has the training and future of his assistant at heart will gradually allow him, under close personal supervision, to carry out more and more of the prescribed tests. It is this practical assistance and experience that is invaluable to the budding inspector.

In due course the junior will act as an assistant in the outdoor duties of the department. It is the invariable practice for an inspector to be accompanied by at least one assistant in his visits to trading premises, usually one for routine inspection at retail establishments, but two or more on industrial or weighbridge inspection. Thenever motor transport is used, the assistant may be required to act as driver of the van or car. Apart from assistance in the mechanical processes on inspection the assistant will be taught to keep his eyes and ears open, as he will frequently be called upon for corroborative evidence in court proceedings arising from reports of infringements. He will be a most important witness in many cases, particularly where he has been responsible for making test purchases to check complaints of short weight or measure. Altogether by constant participation in the supervisional work he will be acquiring knowledge 
and, of great importance, learning how to deal with the varying types of persons with whom an inspector is brought into contact. By precept and example from lis superiors, he will learn the tact ful yet firm approach and be tanght to carry out lis duties with the conrtesy, impartiality, and consideration expected from a public official.

Concurrent with all this practical work, the student will be following a set course of theoretical training. This might take the form of a correspondence course, attendance at part-time courses, lectures within or outside the office, or purely private study. Generally it is a combination of all these. Correspondence courses are available for the weights and measures examinations from a few commercial schools, but probably the most popular and certainly the most successful is the long-established course run by the National and Tocal Government Officers Association. This course provides a programme of carefully plammed study spread over a suitable period for the Testamur Examination of the Institute of Weights and Measures Administration and for the Board of Trade Examination. The tutors for the specialised subjects are qualified inspectors of weights and measures of long experience who we find are also active in their own localities in matters relating to the training of weights and measures persommel. Each vear, immediately before the Board of Trade Examination, the NALGO Correspondence Institute arranges a three-day training course to enable candidates to obtain a final brushing-up by talks and discussions. mock oral and practical examinations, and demonstrations of weighing and measuring equipment provided by various manufacturers of scales, petrol pumps, etc.

The principal objects of the Institute of Weights and Measures Artministration include the following:

d. To provide facilities for the training and education of candidates for the statutory qualification as an Inspector of Weights and Measmes, or for any or all of the Testamur's of the Society.

e. To appoint Examiners and to arrange and amminister snch examinations as may be necessary to test the knowledge and competence of persons engaged in. $01^{\circ}$ seeking to be engager in the alministration of the Weights and Measlles dets or in any other branch of administration, or in any part thereof, in which any of its member's are engaged, and, in proper cases, to issue a Testamur to such persous as may be recommended by such Exaniners as aforesaid as being worthy thereof and/or, to do all or any of such things as aforesaid jointly or in consultation or combination with any person or body (including a Govermment department).

The Institute has been extremely active during the postwar years in pursuance of these aims. The Council has a standing committee for Educational Service, with its own Secretary and at present nnder the chairmanship of a graduate inspector. 'The Controller of Standard Weights and Measures Department of the Board of Trade is a co-opted nember of the committee. An examination, known as the Weights and Measmes 'Testamm', has been established and is widely recomised as an important preliminary to the final statutory qualifying examination. Since its inallgmation in 1951 there have been 18 examinations at which $67+$ candidates have sat, of whom $151 \mathrm{or}^{\circ}$ 22.4 percent have been successful in obtaining Testanm certificates. The proportion of passes to the number who sit indicates the high standard demanded.

The Committee on Weights and Measures Legislation ('The Hodg- 
son (ommittee) in its monumental report to the Government in 1951. willmly commended the Institnte for its "activity in promoting ever" higher" standards in the weights and measures service" and recommented, as ar recomition of the ralue of the Institute's examination, that "its sncesstill candidates should be exempted from the English and Lrithmetic papers (and snch other papers as might from time to rime be (letermined) in the Board of Trade Examination."

"The Institute is proud of the fact that this was the first of the Ilodgson Committee's recommendations to be implemented, for in 1954. after useful and most cooperative discussion with the Controller of Standard IVeights and Measures Department, the Board of 'Trade granted oflicial recognition of the examination by allowing exemption from the English, Arithmetic, and Mechanics and Physics papers in their own examination to holders of the Institute's Wreights and Measures Testamur Certificate. Since then, 116 holders of the Institute's 'Testamur have arailed themselves of the exemption and go have subsequently secured the Board of Trade Certificate.

I training programme for the Testamur and the Board of Trade Certificate has been sponsored by the Institute's Educational Services Committee. A student for the 'Testamur must be a bona fide assistant in a weights and measures office. He must be at least 17 years of age before he can sit for the examination and must have been registered with the Institute for at least twelve months beforehand. I set of study notes is supplied to him covering the subjects other than English, Mathematies, Mechanies and Physics and General Knowledge. These raluable notes have been compiled by expert members of the Institute and deal with Legal (separate sets for Euglish and Scottish students owing to existing differences in procedure in the two countries), Weighing and Measuring Practice and Care and Custody of Standards.

Series of lectures, regular classes, one-day and week-end schools are organised by the branches of the Institute and by individual inspectors particularly interested in educational activities. In at least three areas where there are reasonable numbers of students with fairly easy access to convenient centres, courses have been established in conjunction with the local education authorities. Typical of such courses is one, now in its eleventh year, which provides tuition on three erenings a week during the winter months, with first and second rear classes for Legal topics and Weighing and Measuring Practice and a joint class for Mechanics and Physics. For the specialised subjects, inspectors act as lecturers. Homework is set and terminal examinations held. In several districts, apart from lectures, special demonstrations of particular types of equipment are given, usually with the enthusiastic cooperation of manufacturers of weighing and measuring instruments, who are always ready to loan items of equipment, to provide members of their technical staffs as lecturers, and to welcome group risits to their factories. One firm has for several years, in cooperation with the local Chief Inspector, organised a short course for weights and measures students at their works shortly hefore each Board of Trade Examination.

There are many other directions in which the Institute seeks to promote the interests of the future inspectorate. Registered students may obtain its journal, The Monthly Review, at a nominal subscrip- 
tion rate, they are free to use the Institute's library facilities, encouraged to attend branch meetings and to avail themselves of all the advice and assistance the Institute can give through its enthusiastic Education Secretary. Copies of past examination papers for the 'Testamur and Board of Trade examinations are supplied at a very cheap rate. A special feature at the Institute's Ammual Conference is the presentation of the prize given to the most successful candidate in the previous year's 'Testamur examination.

In common with other local govermment officers, weights and measures students obtain financial assistance from their employers for post-entry training. This includes 75 percent or 100 percent payment for expenses attending recognised courses and at examinations, tuition and entry fees, etc. Time off for study is granted, and altogether every encouragement is given to those who intend to get ahead in the service.

\section{The Examinations}

The Testamm Examinution of the Tustitute of Weights and Measures is held once a rear, usually in October, at rarious centres selected for convenience of traveling. It is spread over three days and the syllabus is summarised as follows:

\section{Engtish}

Essay: The ability to express and develop an idea to a logical conclusion. A knowledge and understanding of the use of the English language with spetcial reference to tundamentals and clatrity of expression.

Precis: 'The ability to grasp the essence of a passage or subject and to state these essentials clearly and concisely, without loss of meaning.

\section{General inouleatge}

An appreciation of the nature and significance of the common objects of daily life. Acquaintance with current events.

\section{Arithmetie}

The rules of arithmetic, fractions, decimals, ratio, proportions, squale root, tables of weights and measures, metrie system, simple and componnd practice. l'urentages, profit and loss, simple and componnd interest. Mensuration.

\section{Legal}

Scope and functions of the various types of courts of law. Elements of legal procedure. Knowledge of the contents of the Weights and Measures $\mathbf{A}$ cts and Regulations. Investigational pocedure, statenents, cautions, preparation and consideration of repolts. Cont procedure, rules of evidence, examination of witnesses, and general conduct of a case. Appeal cases of outstanding significance.

\section{Mechanies and P'thysies}

Ilytrostaties: Density and specific gravity. P'ressure in liquids and gases. harometers, pressure-measuring flevices, air pumps.

Stalies and Dymamies: Units, velocity, acceleration, momentum. Forces, machines and their characteristics. (ilavity. Weight and mass. Work, energy, power, friction and elasticity.

Ileat: Specitic heat. The themmoncer. Hxpansion of solids, liquids, and gases. Conduction, convection, and landiation.

\section{Weighing and Measuring Practice}

Fundanental theory and principles of romstruction of weighing and measuring appliances. Properties of materials used in their construction. Weighing and measuring equipment used for scientific purposes (balance, veruiter, micrometer, spherometer, etc.). Standards and Fquipment. Matrials of construction, methods of use, maintenance, and reverification. 


\section{Practical}

bxamination, reritication and stamping of weights, measures, weighing and measuring instruments. Adjusting of weights and measures. (Candidates "10 expected to be familia only with appliances commonly in use. Speed and accuracy are needed in this $1 \frac{1 / 2}{2}$ hour test.)

Although covering some of the same ground, the examination is by no means a pale reflection of the Board of Trade Examination. In some respects the syllabus is wider, in others the knowledge required is not so adranced. The overall purposes of the examination liave been worked out carefully and they are, in short, to enable assistants to judge at an early age their suitability for a weights and measures career, to help their employers to assess capabilities, to give examination experience, and to produce a higher standard of performance at the Board of Trade Examination. The examiners in English, Arithmetic, Mechanics and Physics and Legal (English and Scottish) are university graduates and nommembers of the Institute. For the specialised subjects such as Weighing and Measuring Practice and Practical and for General Knowledge, the examiners are highly experienced inspectors who hold extra academic qualifications. The markings go to a Chairman of Examiners, who coordinates the results, prepares the pass list, and reports on each examination to the Council of the Institute.

Results are published within six weeks of the completion of the examination. A candidate referred by the examiners in one subject (other than Practical) may take that subject alone at a subsequent special examination. Successful candidates receive a certificate bearing the seal of the Institute, whilst the unsuccessful ones can derive a great deal of cold comfort by noting carefully the remarks of the Chairman of Examiners in his comprehensive report.

The Testamur Examination is a worthwhile qualification in itself and has been recognised as such in a material respect by several local authorities who award improvements in salary gradings to holders of the certificate. Increasingly, it is being regarded as the best method of progression towards the final statutory qualification, and it is undoubtedly succeeding in producing a higher standard of candidate for the Board of 'Trade Examination. Possession of the Testamur Certificate is acceptable as a qualification for admission to associate membership of, and to the accompanying closer participation in the activities of, the Institute of Weights and Measures Administration.

The Board of Trade Examination for Inspectorship of Weights and Measures is also held once a year, in London, usually in April, and is generally spread over three days. Written parts are taken at various centres in the Capital, practical tests and the oral examination at the Standard Weights and Measures Department. At present, nomination for the examination is required from a local authority. This, in effect, virtually restricts the examination to candidates actually employed in weights and measures offices. Candidates must supply a certificate of good character from a nominating local authority, a Justice of the Peace, or their last employer. Regrettably the nomination requirement is not mentioned in the new Weights and Measures Bill, but it is unlikely that any but bona fide assistants will ever stand any chance of success. 
The wording of the syllabus of the examination has changed very little in 70 years, although there has been tremendous change in the scope and variety of the legal and technical items which it covers. A summary of the syllabus is as follows:

\section{English Composition}

Short essay on some subject of general knowledge. Obserrance of the rules of grammar, punctuation, spelling, clearness of handwriting, avoidance of ambiguity.

\section{Arithmetic and Mensuration}

As in the Testamur Syllabus.

3. Mechanics and Physics

Generally as in the Testamur Syllabus.

\section{Weighing and Measuring Practice}

Properties of metals and alloys and of the common protectire treatments. Fabrication of metals. Construction and principles of recognised types of weighing and measuring appliances, including automatic weighing machines and self-indicating derices, measuring pumps, leather-measuring machines, etc. Criticism of special types and patterns. General knowledge of patterns approved by the Board of Trade. Ability to interpret mechanical drawings. Construction and use of reruier, micrometer, comparator, etc., methods of weighing; intercomparison of a set of weights; care and use of fine balances and standard equipment generally.

\section{Acts of Parliamcnt and Regulations}

Knowledge of the provisions of the Weights and Measures Acts, 1878 to 1936; the Weights and Measures Regulations, 1907 to 1949 ; and other Acts of Parliament and Statutory Instruments affecting the duties of an inspector of weights and measures.

\section{Practical and oral}

Testing of weights, measures, weighing and measuring instruments. Adjusting and stamping of weights and measures. (The practical verification tests extend over three hours and again speed and accuracy are the requisites.)

The practical and oral parts are regarded as of particular importance. Practical tests are conducted under the surveillance of officers of the Board of Trade who can observe whether a candidate is familiar with the purpose and usage of items of equipment and whether he possesses a degree of manipulative skill. 'The oral examination takes the form of a personal interview by two examiners of the Department who can make an assessment of the candidates potentialities as an inspector.

All candidates are notified personally how they have fared and their local authorities are also informed whether their nominees have succeeded or not. In due course, a certificate is issued to each of the successful candidates, signed on behalf of the Board of Trade, and this treasured piece of parchment is the passport to a career as an inspector of weights and measures.

\section{Progress Within the Weights and Measures Service}

The proud possessor of the Board of Trade Certificate is now eligible for appointment as an inspector either by filling a vacancy on the staff of his employing authority or by applying for a post elsewhere. Voluntary movement between local authorities is very common, superannuation rights being preserved and service conditions generally being the same throughout the comtry. As mentioned earlier, there is a nationally agreed salary scale for the newly qualified officer so that there is some degree of uniformity in respect 
of the basic pay of the younger inspectors. The additional responsibilities of higlier posts merit improved gradings and a man may make reasomably steady financial progress either by promotion within his own anthority or by moring around from place to place. Providing it is not too frequent, a change of employment is all to the good in weights and measures work as a means of gaining wider experience.

Tacancies are notified by public advertisement in the press, particularly the local government journals and The Monthly Review. Trritten applications are required giving details of age, experience, and qualifications, and accompanied either by copies of testimonials or by the names of persons to whom reference can be made. Canvassing is strictly forbidden. A short list of the candidates is drawn up and personal interviews arranged. These may be by a full committee or by a subcommittee of the Authority, or occasionally by senior officials only. The candidates are interviewed in turn and the selection made on the spot. At present the demand for inspectors slightly exceeds the supply, and some authorities experience difficulty in filling vacant posts. The obvious answer in such cases is an improvement in the financial attraction.

Departments vary in size and scope according to the geographical limits of the administrative area, population to be served, number of trading premises, and other factors such as a concentration of industrial establishments. The smallest type of authority may only employ one inspector of weights and measures, perhaps with one unqualified assistant. The largest county departments may have from 25 to 30 inspectors with the requisite number of clerical and technical assistants.

There the establishment is large, there is a reasonable chance of promotion within the department through the various stages of district or divisional inspector, deputy chief, and chief inspector. For inspectors with the smaller authorities, there is little opportunity of progression except by movement elsewhere. In general, county work is more attractive than in boroughs, and salaries tend to be higher. There is some restriction of movement as from one type of authority to another, say, from a borough to a county, due mainly to variation in the ancillary duties performed. In counties, inspectors of weights and measures often administer the Food and Drugs Acts. On the other hand, the borough inspector will frequently be an officer under the Petroleum and Explosives Acts, which are not generally administered by his colnty colleagues.

In some of the larger departments there may be a degree of specialisation, certain inspectors spending most of their time on such duties as coal inspection, checking petrol pumps, or testing and stamping at a scale factory. While this may be an administrative convenience, it is not too good for the personnel involved to be kept on the same job too long. All-round experience in every aspect of weights and measures work is necessary if a man is to maintain his interest and enthusiasm and not to be at a disadvantage when applying for another post.

Many ambitious inspectors have not been content just to possess the Board of Trade Certificate, but they have by part-time study obtained further academic qualifications. There are in the profession 
today several barristers-at-law and many holders of degrees or diplomas in the sciences, the arts, law, and public administration. It is, of course, noticeable that these men are frequently in the top jobs or in line for them.

The Board of Trade Certificate has become of importance in Commonwealth countries, particularly Africa. British inspectors hold appointments with the Govermments of Kenya, Tanganyika, Uganda, Rhodesia, and Nigeria at the present time and they are playing an important role in introducing weights and measures administration to these developing states and in the training of local personnel. The weights and measures service in the Sudan was pioneered by inspectors from Britain, and there should be other openings forthcoming to those inspectors who are willing to exchange the certainty of long-term security at home for a more interesting life abroad.

\section{Further Training of The Inspector}

An inspector really starts to learn his job after he has qualified and he goes on learning for the rest of his professional life. Weights and measures administration and techniques must endeavour to keep abreast of the ever-changing pattem of trade practices and industrial developments. Unfortunately, in the United Kingdom the law has lagged far behind, and for a long period we have been working under out-dated statutes totally unrelated to modem conditions. Our principal code of technical regulations is 54 years old, and it is a tribute to the foresight of those who framed them that they can still be made to apply to present-day weighing and measuring equipment. However, the long-promised revision of the Acts and Regulations is now in sight, and soon we hope to have legislation that will be more in line with present-day practice.

The Board of Trade does not have statutory powers to initiate or operate any set programme of training for inspectors, but nevertheless, by the very nature of its legal functions, it does give a great deal of assistance to those local officinls whose job it is to carry out enforcement in the field. For example, under the provisions of Section 6 of the Wreights and Measures Act, 1904, every commercial device for weighing and measuring possessing novel features must be of a pattern approved by the Board of Trade before it can be accepted for verification and stamping for use in trade. For each pattern approved, a notice is issued and copies are distributed to every weights and measures authority in the country. These notices. and there are nearly 1.300 of them, contain photographs, drawings, and descriptions of the approved patterns, and they form an invaluable reference library for the inspector. In the same way descriptions of many thousands of minor modifications to approved patterns are made available to the inspectorate by appearance in the bulletins issued periodically by the Board of Tirade. These bulletins also contain other items of value to the inspector, imparting as they do the opinions and decisions of the Board when they have been consulted on certain aspects of the regulations. Officers of Standard Weights and Measures Department are always willing, within the limits of their statutory powers, to give advice and assistance on the many legal and technical problems posed to them.

It was suggested in the Report of the Committee on Weights and Measures Legislation that there should be organised refresher courses 
for inspectors of weights and measures, and one cannot help but feel somewhat disappointed that nothing appears in this commection in the new Treights and Measures Bill. It is, of course, debatable whether this is a proper function for the Board of 'Trade or whether such courses should not be organised by the local authorities themselves. 'There are difliculties such as the question of financing out of local funds. granting of special leave for the participating inspectors, and obtaining the services of suitable lecturers. None of these are insuperable and, if there were some form of sponsoring by the Govermment, it is likely that professional courses would be readily organised ind rell supported by the local authorities throughout the country.

The Institute of Weights and Measures Administration plays an important role in the post-qualification education of the inspector. 'The first three of its principal objects, declared in the Memorandum of Association, are:

a. To adrance the legal, technical, scientific, practical, and general knowledge of persons engaged in the administration of the Weights and Measures Acts and any other legislation or duties which can or may be administered or undertaken by its members.

b. To promote the interchange of ideas, opinions, and experiences between its members.

c. To provide facilities for and to promote and encourage research and learning in all subjects and matters relating to or affecting the administration of the Weights and Measures Acts and any other legislation or duties which are, or may be, administered or undertaken by its members, and to record and preserve and make arailable the results of such research and learning for the benefit of students and all such persons as may be interested therein.

In pursuance of these and other objects, the Institute maintains a constant policy of disseminating information in as many ways as possible. Its journal The Monthly Review is supplied to all members, who constitute practically 100 percent of the inspectors in the country, and of course to many subscribers other than inspectors, both at home and overseas. It publishes news and views on every topic of interest in the sphere of weights and measures, including technical and legal articles, reports the activities of the Institute and its members, and the unbroken series of volumes for the past 68 years on anything connected with weights and measures.

Other means for the interchange of ideas and experiences are through the medium of the Amnual Conference and branch meetings. Before World War II the Annual Conference was invariably held in London, but since 1946 the venue has changed each year. A pattern has been established so that the Conference visits each of the Institute's branch areas in turn. This, we believe, has the effect of "selling" weights and measures in different parts of the country and also gives the opportunity to many inspectors of visiting the Conference when it is near to their locality, which perhaps they could not do when it was always held in London. 'The Conference sessions are devoted to the presentation of papers, open forums, sectional meetings, and the transaction of Institute business. An exhibition of weighing and measuring equipment, both commercial and standard, is held in conjunction with the Conference and is well supported by the manufacturers who welcome the opportunity of meeting in this way the delegates and visitors. 
The 11 branches of the Institute in England, Wales, and Scotland hold regular meetings (as do those in Northern Ireland and East Africa), usually twice a year. These are very well attended and provide lively sources of discussion of matters of common interest. Again, papers are read, question and answer sessions held, mock trials arranged, and group visits made to places of interest such as large industrial plants. It is considered that the strength of the Institute is derived from its branch organisation, which stimulates and maintains the interest of the inspectorate in the various localities.

The facilities of the Institute's library are available to all members of the Institute. Established only 6 years ago, it has been built up into a repository of several hundreds of volumes on weights and measures and kindred subjects. Legislative codes from all parts of the world are on file, as are many periodicals, press cuttings, and papers. The publications of the National Bureau of Standards feature prominently among those donated from abroad.

There are two standing committees of the Council of the Institute which are of particnlar use to the inspector seeking guidance in his work and further studies. The Reference Committee deals with queries from members on points of legal and administrative difficulty, while the Publications Committee, apart from supervision of the business side of The Monthly Review is responsible for various other publications such as the Weights and Measures Handbook, memoranda, and treatises on many different subjects. Work is well in hand on what we believe will be a major contribution to weights and measures knowledge in the form of technical books on weighing and measuring instruments, while there is also prospect of a legal textbook once the new Act is settled.

In September 1961 there will be held at a College of Cambridge University the first advanced professional course of its kind in Great Britain. This will take the form of a weekend school for about 70 inspectors on such subjects as:

1. Law of contract and sale of goods.

2. Law of evidence and Court procedure.

3. Statistical analysis of errors on prepacked goods.

4. Economics of production as applied to weight and quality of goods, and types of containers.

5. Electronics as applied to weighing and measuring instruments.

6. I'sychology in P'ublic Administration.

The school has been organised by the South East Midland Branch with the wholehearted support of the Council of the Institute. Local authorities have responded well in authorising the attendance of their inspectors. The outcome of this project will be watched with interest, for it is regarded as a pilot scheme and, if successful, it will no doubt be followed by similar schemes in other miversity centres.

Interest in the use of visual aids for training purposes has been fostered by widespread showings of the films "A True Standard," "Testing Mass Standards by Substitution," and "AssignmentWeights and Measures" kindly donated by the National Bureau of Standards to the Institute. These have been exhibited to many gatherings of inspectors and their assistants, and it is hoped that it may be possible to undertake the production of similar films in Britain when the financial obstacles can be overcome.

Whatever help the weights and measures official may get in his 
rocational training from outside sources will only be complementary to the facilities arailable in his own office. The younger inspector in particular should be encomaged to discuss problems with his colleagues, and he should have ready access to the office library and to those periodicals to which the department subscribes. In the larger departments there should be regular meetings of the chief inspector and all the qualified staff. An inspector should not be kept on a specialised job too long, and an interchange of district from time to time will be beneficial to him and perhaps also to some of the traders. Novel items or special installations of weighing or measuring equipment should quickly be made known to all the inspectors. An interesting job can be made still more interesting by variety, and there is certainly plenty of that in weights and measures administration.

\section{What of the Future?}

That there is need for expansion of training facilities both for the unqualified and qualified weights and measures official is beyond question. Technical progress will continue, trading practices will change, and our service must be kept up-to-date by placing all possible sources of information at the disposal of the officer who will be called upon to deal with the new problems which inevitably arise in the course of his duties.

So far as the United Kingdom is concerned, it is evident that the syllabus of the Board of Trade Examination will shortly have to be revised in the light of forthcoming legislative changes. A single Act of Parliament will replace about a dozen statutes dating back to 1878 , and it will be followed by an array of new regulations dealing not only with the weighing and measuring equipment at present under control. but other devices with which hitherto the inspector has not been directly concerned. The new Act will apply to a wider range of commodities than do the present laws, and there will be power to bring still more under control from time to time.

There is a significant difference between the wording of Section 8 of the Weights and Measures Act 1904 and that of the corresponding clause of the IVeights and Measures Bill in the reference to the inspector's examination. The former refers to the holding of examinations for the purpose of ascertaining whether candidates possess "sufficient practical knowledge for the proper performance of the duties of inspectors of weights and measures." Clause 43 of the Bill says the examinations are to test whether candidates possess "sufficient skill and knowledge." This seems to have wider implication, and the students for the examination in the future will need to possess even more qualities than are needed today.

As remarked earlier. the scope of weights and measures administration is too wide to be covered by one examination. Already there is the Weights and Measures Testamur as a staging point on the way to full qualification, and it could well be that in the future there will perforce have to be a preliminary, intermediate, and final stage. At present there is nothing in the examinations relating to electricity and magnetism-a deficiency which will have to be remedied in view of the increasing application of electronic principles and techniques to weighing and measuring equipment. Also, whilst a candidate is examined as to his knowledge of the content of the weights and 
measures laws, there is no reference in the Board of Trade syllabus to the constitution of the judicial system, court procedure, rules of evidence, and the various legal processes. The spread of prepackaging and increased activity in the supervision of commodities have indicated a need for at least an elementary knowledge of statistical method and sampling procedure.

Clearly the whole system of examination for weights and measures persomnel needs to be kept under constant review. The Institute of Weights and Measures Administration is prepared to play an increasing part in the training and examination programmes, but it must be emphasised that it has no wish to assume the function of issuing the final certificate of qualification. It is envisaged that this should always remain with the central Government. 'There is dignity and prestige in the fact that alone in the local govermment service the inspector of weights and measmres possesses a qualification granted by one of H. MI. Departments of State.

On the trining side, one would wish to see further extension of the activities at present in operation. Nore classes and lecture courses for students and inspectors should be provided, increased use made of visual aids such as films, film-strips, and slides, and the dearth of up-to-date literature on weights and measures subjects made good. Some system of interchange of students between the different types of jurisdictions would be useful, whilst for the inspectorate there should be facilities for international exchange such as exist for certain other professions. Many overseas students, particularly from the newer conntries of the Commonwealth, have risited Britain for weights and measures training. There already exists a regular exchange of publications, etc., between the British Institute and official olganisations in such countries as Australia, Belgium, Canada, France, Germany, India, South Africa. United States of America, and U. S. S. R. Eren more useful would be a periodic exchange of the weights and measures officials themselves. A part from being a contribution towards international understanding, such an exchange would provide unique opportunities of acquiring new ideas and experiences in the sphere of weights and measures administration.

\section{Conclusion}

In reviewing the training and educational activities in the British weights and measures service, no claim is made either that they are unique, original, or by any means perfect. Similar projects will be in operation elsewhere, and in this respect we are anxious to benefit from the experience of our colleagues in other lands who will have developed other methods of selecting and training their oflicials. The system of dual control operative in the United Kingdom, with different aspects of responsibility resting between the central gover'nment and many local authorities, makes coordination of training activities rather difficult. Nevertheless, we feel that sound progress is being made, although there is no complacency about the future.

If stress has been laid upon the part played by the Institute of Weights and Measules Administration, it is because of familiarity with its policy and ideals. As the sole professional representative body of the inspectorate, it is conscious of its responsibility to present and future members in particular and to the community in 
general. No eflort will be spared to do all that is possible towards elevating the dignity and standing of all engaged in weights and measures administration. In these endeavours the Institute looks with confidence towards increasing cooperation and support from the central and local government authorities in Great Britain.

\section{Discussion ON FOREgOING PAPER}

Mr. Crawford: Mr. Roberts, your talk this morning created in our minds a very high opinion of the administration of weights and measures in England. We are very happy to have had you here, and at the same time all of us would like to express our feelings of good cheer and happiness because of the accord and reception that you gave Mr. Bussey over there and the honors that you accorded him. TTe hold him in high esteem.

I have met a number of inspectors from Great Britain and Europe. It has been interesting to talk to them about their procedure in testing weighing and measuring devices. I understand, Mr. Roberts, that many devices are brought into your laboratories or your offices for testing. Would you please tell us about this?

Mr. RoBerts: Our work is roughly divided into two categories. The first is broadly equivalent to what I think you call the mechanical, and the second, supervisional. With us it is verification and inspection. Inspection, as the name implies, is the visiting of all types of trading premises to see that the equipment is up to standard. Verification is the work of testing new or repaired equipment, because our law says that nothing can be put into use until it has first been tested and stamped by an inspector. 'This work of verification does entail the bringing into our offices of quite a number of different types of equipment. The smaller scales, for example, will be brought to us for test, although it is also quite common for inspectors to risit the premises of scale makers and there carry out the tests.

In fact, in those centers where there are scale manufacturers, inspectors are engaged almost full time at these factories verifying and stamping the smaller types of equipment. This does not apply to dormant scales and weighbridges. 'These have to be verified where they are installed, in situ. The same thing applies to petrol pumps or, as you know them, gasoline pumps.

It is the fundamental feature of our work that nothing can be put into use until it has been stamped. We charge fees for that work, very nominal fees which do not by any means make the department a paying proposition. Verification is a valuable service not only to the public, but to the owner or operator of a piece of equipment, who it is felt should pay a little towards the cost of that service. A device will be examined at least once a year by the inspector on his rounds, and no charge is made while it remains correct. If it is found incorrect, it has to be repaired and resubmitted to an inspector, who stamps it and charges a fee.

The only adjustment carried out by inspectors is that of weights used with equal-armed scales. This limited authority to adjust is granted by the Board of Trade, who have to be satisfied that an office is properly equipped for doing the work and that the work of adjustment will not interfere with the primary duties of verification 
and inspection. It has, in many areas, been found a great convenience to traders and saves them having to send their weights long distances to be adjusted and subsequently to be submitted to an inspector. We do not adjust scales or measuring devices of any kind. Our job is simply to test them.

Mr. Fernsten: I have two questions to ask you. You mentioned that some 38 percent of the candidates had passed the Board of Trade examination. Do you have a percentage figure on the Testamur examination?

Mr. Roberts: It is much lower than that and runs to about 23 percent over the 10 years in which the Testamur has been established.

Mr. Fernstex: Then your examinations are rather severe, as you stated.

Mr. Roberts: Both examinations are, we consider, very severe indeed. The 'Testamur examination may be considered as a sort of screening examination. It is designed mainly to determine the aptitude of a youngster for this particular work, to give examination experience, and to produce a better standard of candidate for the Board of Trade examination.

Mr. Fernsten: I gathered from your talk that you have probably three types of people who work in the field. You have the trainee, the assistant, and the inspector. Could you give us any idea of the relationship of the number of personnel? Presume you have twelve inspectors. How many assistants would you have in an operation of that type and how many trainees would you have?

Mr. Roberts: Perhaps I can best illustrate this by quoting the figures for my own department. The City of Manchester has a population of about 670,000 at the moment. The total personnel in my department is 30 , of whom 12 are qualified inspectors. There are 14 men who are engaged as assistants, one as a handyman, and we have a small clerical section of three. Of the 14 assistants I mentioned, there are perhaps half a dozen youngish men who are contemplating carrying on to become inspectors. It is largely up to themselves.

The examinations are open and competitive and no bars are put in the way of anyone in the department who wishes to proceed to qualifying as an inspector and is prepared to devote the necessary time to study. I think this gives a fair picture of the position throughout the country.

Mr. Bowex: First, I would like to say that I found Mr. Roberts' address thoroughly interesting, and I am quite impressed with the apprenticeship that the inspector must first serve. This should lend considerable prestige to the oflice.

My question is this: I noted in your address, Mr. Roberts, that your stated there is a proposal to increase the penalty for impersonation of inspectors by a factor of ten, that is, from $\$ 30$ to $\$ 300$, for a first offense. The thought has crossed my mind, is this because you are troubled with an increasing number of impersonators, an increasing number of repeating offenders, or what is the reasoning behind this proposal to increase the penalty?

Mr. Ronerts: To my knowledge, sir, there has never been a case before the Courts of an impersonation of an inspector of weights and measures. 'The provision is there to emphasize the extreme im- 
portance of this certificate and to fix a penalty for anybody who violates by acting as an inspector withont being qualified. The penalty I mentioned, the 100 pounds or roughly $\$ 300$ for a first offense, is the general penalty being proposed in our new bill.

Mr. Turnisula: Do you have a weights and measures law that is common to all Great Britain or do you also have your local legislation?

Mr. Ronerts: The Weights and Measures Acts 1878 to 1926 are applicable throughout the whole length and breadth of the United Kingdom. 'There are, however, certain local provisions. Many local authorities have become impatient with the deficiencies of our outof-date national legislation and have promoted their own bills through the full process of Parliament. The weights and measures provisions of these bills are usually included with other powers being sought by the local authority. A local bill must go through all the stages in the House of Lords and the House of Commons, and when it has finally received royal assent it has the same effect as a national act, although it only applies in a particular locality.

If I may again quote Manchester as an example, our national law does not apply at present to the sale of coke and other manufactured solid fuels. So, many years ago my authority obtained powers to bring these fuels within the ambit of the weights and measures department. After the last war we went a stage further and included wood fuel and we also obtained local powers to deal with person-weighing scales.

In the bill now before Parliament, it is proposed to repeal all local weights and measures legislation so that we shall all be working under the one unified code. If it is going to take another century to get round to another national act I have no doubt the local authorities will again be promoting their own legislation.

Mr. Morton: I think this question will be of interest to a lot of people in the room, Mr. Roberts. What monthly salary do your inspectors receive?

Mr. Roberts: You, sir, have touched upon a very delicate subject. I can answer your question very briefly by saying "not nearly enough." I expected there would be some interest in the matter, so I have touched upon it briefly in the paper which you will read in due course with the report of the Conference. The impression I have been able to gather during my travels is that our inspectors are getting about half of what your inspectors are getting. This is a very, very general statement, and you must bear in mind the considerable difference in the cost of living in the two countries. The general rate of pay over here is, of course, considerably higher than it is in Europe, although with our welfare state in Britain we do have certain "hidden assets."

The negotiating machinery for the local government service has fixed a basic salary for the newly qualified inspector of weights and measures. The starting figure is roughly $\$ 2,200$ a year, rising by annual increments to $\$ 2,880$. Salaries for the higher posts are at the discretion of the local authorities. As a professional body, the Institute of Weights and Measures is not concerned with salary matters, but there are other organizations of a trade union but nonpolitical nature who look after our material interests. 
Mr. Fany: Mr. Roberts, first I would like to commend you on your paper. I thought it was very well presented. My question is: Why are not your examinations open to the public, all people who are interested in weights and measures work? Why is it necessary for a person to be nominated by the local authorities?

Mr. Roberts: The existing nomination procedure has been effective since 1904. It does not necessarly mean a man has to be employed in a weights and measures department, but he must have a nomination from a local authority. There have been cases in the past where men from outside have secured these nominations, but, believe me, unless there is the practical training in the department there is not an earthly chance of passing the examination. The examination is essentially a specialist one, designed to test the person's practical knowledge of the weights and measures regulations and weighing and measuring techniques, and his general educational standards.

I suppose it is theoretically an open examination, providing the nomination can be secured, but nominations are not given lightly by the local authorities, and they invariably give them only to the men whom they employ as their future inspectors.

We have perhaps what you might regard as a closed shop with our Institute Testamur examination. Again we did that deliberately, because we know from wide experience that, unless a man is actually employed in a weights and measures office and has had this prime training, he is just wasting his time to try these examinations.

Mr. BuackвUrx: We were pleased with the emphasis on local authority. What information do you have conceming traders that have infringements in one jurisdiction and yet, on the other hand, go along and operate throughout Great Britain and even Scotland and Ireland?

Mr. Roberis: The have extremely good liaison between our departments. The word is rery quickly passed around. We have not a rast continent like you have. Ours is a comparatively small country, and it is quite easy to get information from one end of it to the other very quickly. There are, of course, police records a railable.

The Institute's Journal. The Monthly Review, carries reports of prosecutions, and an inspector who follows those closely can usually remember whether the trader he is concerned with has been conricted previously. If he is a local trader perhaps operating from a nearby jurisdiction, it is just a moment's job to get on the telephone and ring up your opposite number" and say, "Have you had any trouble with so-and-so?" And we can usually get the information straight away. We have had no great problem in tracing previous infringements.

Mr. Crmmste: There is no doubt in my mind as to the professional quality of your inspectors of weights and measures, and, in view of your experience in that regard and the trip that you have made in the United States and the accentuation of the positive that is now taking place on education of weights and measures men here, I would like to impose upon your friendship for an answer in that regard, and the question is this: Would you mind giving a suggestion as to what point we should pay attention to in our meth- 
ods of training, in view of the method of acquisition of inspectors in our United States?

Mr. Ronerts: It is most diflicult to give an answer to that, Mr. Christie, because your methods of recruitment and training seem to vary so differently from ours. But I would say the most important thing, of course, is to lay the greatest emphasis possible on the quality of the men you recruit. Make sure that they have the educational background necessary to study and apply laws and regulations, make sure that they have some mechanical knowledge and aptitude, and also that they are men of good standing dignity who will give added prestige to your department. I hesitate to suggest it, but we are here among friends, and I do think if you had a national qualifying examination it would be helpful. I hope you will not take that amiss, gentlemen. We have found that it has been an extremely good thing, and I think we do stand fairly high in the public regard and in the regard of our employers and of the central government in Britain.

Mr. Richandson: Mr. Roberts, there are in industry many applications for weighing which do not directly affect the public. For example, apportioning the ingredients that go into an end product, recording the total amount of material produced, perhaps for inventory purposes, weighing coal for boilers within a plant, and other weighing applications in the whole field of process controldo your weights and measures inspectors follow through on that type of weighing equipment, maintenance, and so forth?

Mr. Rorerts: No, sir. We are concelned solely with weighing and measuring devices used for trade-that is, for buying and selling, prepackaging, checking-in, computation of wages, and the like. Any derices such as those you mentioned are definitely outside the scope of our weights and measures acts and would not be tested by inspectors except upon request. If we were requested to test such devices, we should as far as possible apply the weights and measures regulations, although the device would not be stamped as legal for use in trade.

Mr. G. L. Johrson: Have you had a labeling problem such as misleading advertisement, as was discussed this morning?

Mr. Roberts: Indeed we have. Prepackaging, of coulse, is not so highly developed as it is in the United States, but nevertheless it is increasing constantly, and we are getting the same problems as were so ably demonstrated to us this morning. We have not quite the huge variety of fantastic claims, but even so we do have "giant," we have "large," we have "handy household" sizes, and all sorts of meaningless descriptions of that nature. We are working very hard at this problem, as are two extremely active consumer organizations, the Consumer Advisory Council of the British Standards Institution and Consumers Association, Limited. They have interested themselves very much in this question and have given wide publicity to it. There is a Government committee sitting at the moment inquiring into all aspects of consumer protection, including the Merchandise Marks Act, which deals with the mislabeling of products. Evidence has been submitted by my Institute and the two other bodies I have mentioned, and we are hoping that, when the committee issues its report, it will make certain suggestions for legislation to deal with this problem. 
Mr. Grassi: What is the legal status of your Institute and how can membership in that Institute be acquired?

Mr. Roberis: We have legal standing in that we are approved by the Board of Trade. We are recognized as a professional body of public officials. Corporate membership is restricted to qualified inspectors of weights and measures holding appointments in the United Kingdom or with similar qualifications and appointments in other parts of the British Commonwealth.

We have other categories of membership. An associate member must be a bona fide weights and measures assistant, holding either the Board of Trade Certificate or the Institute's Testamur. We have a category of honorary membership which is available to a person who is not an inspector of weights and measures, but who is associated with weights and measures administration otherwise than in the manufacture, sale, or maintenance of weighing and measuring appliances. Other categories are those of Fellow, Life Member, Retired Member, and, of course, we have a President and Vice Presidents.

At present, membership is in general confined to weights and measures personnel in the British Commonwealth, but that does not prevent anyone getting in touch with us at any time and subscribing to our journal. The MIonthly Review. TVe firmly believe the more interchange with our opposite numbers abroad, the better.

Mr. Grassi: Who publishes the magazine?

Mr. Roberts: It is obtainable from J. R. Roberts, Weights and Measures Office, Manchester, England, who is responsible for the circulation.

Mr. Sinpers: You say your law is nearly 100 years old. There has been, I would judge, a lot of improvement in weighing devices and measuring devices, of course, in that period of time. You can see the work of this Conference is changing the tolerances and specifications all along every year. I think in 47 years it has been changed every year. How do your tolerances and requirements for scales and weighing compare with ours over here?

And the second question is that you did not mention, I believe, that scale manufacturers and measuring equipment manufacturers, as associate members of your Institute, have the freedom of the floor, and so forth, in discussions.

Mr. Roberts: I will answer that one first, Mr. Sanders. They are not eligible to become members of the Institute. As I say, it is purely a professional association and nobody can be a member if he is engaged in the manufacture or selling or repairing of scales. But do not for one moment think that we have anything but the most happy relationships with our friends from the industry. They attend our annual conference. Mrost of the firms are represented there, just as they are here at your Conference. The freedom of the floor at the public sessions is theirs. We hold an exhibition of weighing and measuring equipment at our conference in which our manufacturers participate. As I say, we have the most friendly relationships with them, but each side recognizes the division between our respective interests and responsibilities. Here I would like to say that the British manufacturers are extremely helpful in our training program. They have no hesitation whatsoever in sup- 
plying lecturers to our classes of students, to inviting them to visit their works, and to do all they possibly can to assist us.

In fact our lilrgest manufacturer in Birmingham, prior to each Board of 'Trade examination, runs a full week's course for students who are going up for the Board of Trade examination. This is done in conjunction with the local chief inspector, and it is indeed highly successful. I mentioned earlier on the National Association of Local and Government Officers and their correspondence course. Ther, too, hold a mock examination and short practical course the weekend before each Board of Trade exam. I had the privilege of visiting that course shortly before I came here, and I was agreeably surprised at the display of material they had. I think every manufacturer who had been approached had donated items of equipment. They are most cooperative, but nevertheless they are not eligible to be members of the Institute.

As to your question on old legislation, when I said there had been no major revision for a century, I did not, of course, mean there had not been amendments from time to time. The oldest act we have is not quite a hundred years old, 1878. It has been amended in 1889, 1897, 1904, and so on, right up to 1936 , with requirements with regard to the labeling of packages as recently as 1957. But the principal code of technical regulations under which we work was issued in 1907. Again these have been amended from time to time, but it is most difficult on occasion to make the testing of some of the modern derices fit into the wording of the regulations. It really is amazing how well they have worked, and $I$ think it is a great tribute to the foresight of the people who framed them that eren in these days of such advanced technological progress we can make these regulations apply to our weighing and measuring devices or the manufacturers can make their devices conform to the regulations.

Then we have the new weights and measures act, it will be followed, we expect, by brand new regulations. It is intended to modify and modernize all the existing ones and to provide new regulations to cover the devices which at present are not under control. I hope eventually before I retire to see a full up-to-date code. Things move rather slowly in Great Britain.

Mr. Wildrick: I was interested in your opening remarks. You said there were 850 qualified inspectors, excluding Ireland. I wonder about the situation in Ireland.

In Europe we hear they are tough on offenders. Could you explain the policy in Great Britain?

Mr. Roberts: So far as Ireland is concerned, in the part that is connected with the United Kingdom, Northern Ireland, the inspectors are state employees. They work for the Government of Northern Ireland, and their Ministry of Commerce does have an examination which is very much the same as our Board of Trade examination. In fact, I understand that at one time the Board of Trade conducted the examination for them in Belfast.

With regard to the Republic, I am not on safe ground here because, of course, it is an independent country entirely. But I do know that in certain cities they employ civilian inspectors, and they too pass examinations conducted, I think, by the Ministry of Commerce of the Republic of Ireland. In the rural districts of Ire- 
land the job is still being done by the police. But here again they do insist, I gather, that their men go to Dublin and take an examination held by the Ministry.

With regard to your question as to the policies toward offenders, here, of course, we are suffering very much from our antiquated law, because by our Weights and Measures Acts of 1878, 1889, and so on, the maximum penalty for a first offender is only 5 pounds. That is roughly $\$ 15$, with 20 pounds or $\$ 60$ for a second offense, but with liability to imprisonment if willful fraud can be proved.

Under the bill now before Parliament, those penalties will be considerably increased. It will be 100 pounds or $\$ 300$ for a first offense, $\$ 750$ for a second or subsequent offense, with the additional liability to 3 months' imprisonment with no mention at all of willful fraud. So if there is a serious violation, even though it may not have been possible to prove willful fraud, the magistrate can send the offender to prison.

We have had a lot of trouble in my city with the delivery of solid fuel, the bulk of the prosecutions being a gainst carters in respect of short reight. The magistrates have realized that the monetary penalties are hopelessly inadequate, and when we can prove fraud, as we can on many occasions, they have no hesitation to send the offenders to prison, 14 days to 2 months being quite common. We have had them sent to pirson for 6 months and more where they have had previons convictions.

Mr. Wrens: To what extent do you act when you go into a retail establishment and find slight irregularities, or do you offer educational assistance to try to help the people, assuming that you are not entirely satisfied that there is a deliberate intent to defraud? If so, to what extent do you help these people comply with your requirements?

Mrr. RoberTs: We do that to a very considerable extent. We are not there to take people into court for the slightest violation. We often given verbal cautions on the spot and send written cautions when appropriate. All the time we give all the advice and assistance we possibly can. Mannfacturers and packers are encouraged to cooperate with us, and they do. They are welcome to come to us when they launch a new prodnct to see if their labels are in order, or they request ns to go to their premises to see that their packing methods are in line. In general, we do as much as we possibly can by advice and assistance, and only resort to the courts when there has been a serions violation or disregard of previous warnings.

Mr. Harvex: Thank you, Mr. Roberts. It has been a most inspiring and well presented bit of information. I think we are in a position now to better exchange our own field of endeavor, and I am sure that, as a result of what we heard this molning, we will be able to make considerable improvements.

I would like to suggest that the Conference give Mr. Roberts a rising vote of thanks for the presentation.

(The audience stood and applauded.) 
AFTERNOON OF WEDNESDAY, JUNE 14, 1961

-No Business Session-

\title{
OFFICIAL LUNCHEON-WEDNESDAY, JUNE 14, 1961
}

\author{
(R. F. Meek, Chammax, Presiding)
}

\section{ADDRESS}

\section{By Hon. Pinlip A. Hart, U.S. Senator, Michigan}

The story of weights and measures is the story of cirilization itself. The ancient cultures of China, Egypt, Rome, and Greece had highly developed systems of weights and measures. Such great names in history as Charlemagne, William the Conquerer, Henry the Eighth and Talleyrand instituted filr-reaching reforms reflecting their awareness that civilization could not prosper and advance without precise weights and measures. The French Revolutionists began their reform of weights and measures while the guillotines were still doing their work.

In our own country, George Washington in his first inaugural message urged Congress to exercise the power given it by the Constitution and promptly fix weights and measures. It is interesting, indeed, that the founding fathers, although reserving most powers to the States, specifically set forth that this particular power should be exercised by the Congress.

The Bible makes numerous references to weights and measures of which Proverbs $11: 1$ is typical: "A false balance is an abomination to the Lord, but a just weight is His delight."

It is important to appreciate fully the historical significance of your work for two reasons: First, because you are, in fact, custodians of the tools from which the vigor of our present society has been shaped. Second, because in our society where easy credit is a current phenomenon and the credit card has in many cases replaced the dollar as a medium of exchange, the importance of honest weight and measurement is often lost from sight. I suspect you find this to be a continual source of dismay and discouragement as you pursue your daily tasks. You often deal with fractions of ounces and pounds. And when you insist that a designation be accurate, you are likely to hear the expression, "so what" instead of "thank you."

It is necessary to understand the historical significance of weights and measures and their importance to every branch of industry, commerce and science if we are to proceed with vigor and directness to answer those who would "so what" this society into a state of complacency and decay.

Your heritage is the most refined, advanced system of standards in the history of man. Your duty is to guarantee that these standards are followed and adhered to in the market place. Your privilege is to plan, build and improve for future generations.

This task faces a greater threat today than at any time in the history of this country. This threat results from the general tone of morality existing in today's world as reflected in the market place. Too often "what can I get a way with" has replaced "is it right or 
wrong, honest or dishonest." Too often we see a producer, for instance, penalized for a forthright declaration of package content, while his competitor gains a trade advantage by not being so forthright.

Morality in this regard, I should point out, means not only the condition of our own souls. It means the preservation of this free enterprise economy as we practice it in America today.

However, I'm convinced that people are not any different now than they have erer been. We have always had the knaves among us, those who would not hesitate to extract an additional penny from their fellow man by over-reaching or deceit. But conditions have changed. It's easier today.

When the butcher was caught with his finger on the scale, the houserife was outraged. This was cheating. Once detected, it was easily understood. But the techniqnes for misleading the consuming public are today subtle and refined. They are not so easily detected and even when detected, their effect is not easily understood.

Which brings us to the point of why I happen to be here today. If some of you have not asked this before, I'm sure you are wondering it now.

Recently the Senate Antitrust and Monopoly Subcommittee was authorized as follows:

Under the direction of Senator Hart to examine, investigate and make a complete study of the nature and extent of trade practices affecting consumers in a manner which tends or may tend to restrain competition ... with particular reference to deceptive, misleading, fraudulent or unfair practices in the production, processing, packaging, labeling, branding, advertising, statement of prices and other conditions of sale, marketing and furnishing of goods and service to consumers.

Now this is a rather broad grant of authority. My staff and I considered this problem carefully and the answer clearly pointed to the field of packaging and labeling. Frankly, this would not have occulred to me before we started the study. On the other hand, after cursory inquiries, the great need for illmmination in this broad field became obvions.

Pre-packaging as we understand it today is a relatively recent phenomena, having mushroomed only in the past 10 or 15 years with the demise of the neighborhood grocery and the rapid takeover by the griant supermarket, stocking as it does approximately 6,000 items, including varions sizes in the same product.

It is estimated that today's consumer may spend up to $\$ 850 \mathrm{mil}$ lion dollar's a day for such products. It is further estimated that packaging of such items has become a $\$ 10$ billion a year industry. This represents a large share of our gross national product.

Yet our economic system still demands that the consumer make a rational choice in the market place among the 6,000 items vying for her attention and money. 'This is the decision which in our econony determines what goods shall be produced and in what amounts. Can she make such a decision in today's market place? Are the packages and labels designed to aid her in performing this vital economic function by giving her useful information to guide her, or do they give a false and misleading image of the quantity and price of the product inside? As she walks through the supermarket aisles 
at 60 feet per minute, is the shopper able to read and understand labels and packiges, to compare prices?

And how is the producer affected whose package is designed to give clearly stated information in competition with one who does not?

Yim frank to say that as yet we don't know the answers but we certainly hope to find out.

Meanthile, the complaints pile up.

From Chicago:

As a pensioner, who must subsist on $\$ S 1$ per month, (and there is an army of us) my interest is a little more than academic in, let's say, the conventional 1-pound can of liash, which supplies me with two neals, when to my dismay I find it to contain only $15 \mathrm{oz}$. or less.

\section{From Detroit:}

Mr head is in a whirl when I get home from a day of computing relative values on vast numbers of grocery items . . For example, I have to stop and figure out whether it's cheaper to buy $6 / 99 \phi$ small cans of frozen juice (orange) or $2 / 43 c$ large cans.

It is my opinion those responsible should be satisfied that I spend my money in the store and keep the children quiet and orderly while there without the added hardship of these little math tests.

\section{From California :}

We have run into a problem in our mathematic book. We cannot figure out the sizes of canned food cans. Can you explain? Thank you.

\section{From Pennsylvania:}

- Another question which bothers me would be why the smallest size is called large ; the next smallest is called giant; and the next called king size?

And a personal observation: I am curious to know why the jumbo half quart now seems to have replaced the traditional pint.

Another long list of complaints concerns products on which it is next to impossible to find the net weight designation, because, for instance, it is on the bottom panel blended into the background. Such placing and size of the net weight content or package count often corresponds with a drop of the contents in the package. Maybe the practice is not as prevalent as the complaints indicate. Perhaps there are good reasons for such changes. Maybe these practices do not really confound the purchaser. I hope that by the time your next annual convention rolls around we may have some of the answers.

If you will permit me one last reflection: This afternoon you will hear an address by J. H. Chaloud, Associate Director, Product Development Division, The Procter and Gamble Company on the subject of Quantity Control at Procter and Gamble. I'm sure you will be very much impressed by the very commendably complex and thorough procedures used to guarantee that the housewife gets the amount set forth on the package.

Yet, what is the effect of these complicated controls by the production personnel when the housewife is not able easily to tell from the package or label exactly what amount she is getting and what price she is paying for it compared to other brands and sizes? My only point is that to get full value from this type of production control, it is equally important that this type of care and research be carried over into the design of packages and labels to the end that the consumer can be properly informed. 
You have years of experience in your job and know far better than I the problems involved. That's why we appreciate so much the cooperation we have received from State and Federal weight and measure officials and why we look forward to your continued help.

The job you do is so essential to the vitality of our economic system that anything less than your finest effort would be highly damaging. Based on your accomplishments to date and your plans for the future, I have the greatest confidence in your ability, competence and dedication in getting done this too often unsung job.

Now that I have an opportunity to assist with these compelling problems, I hope I can measure up to the standards you gentlemen have set.

THIRD SESSION-MORNING OF THURSDAY, JUNE 15, 1961

(H. D. Robinson, Vice Chairman, Presiding)

\title{
REPORT OF THE COMMITEE ON NOMINATIONS AND ELECTION OF OFFICERS
}

Presented by C. H. Stender, Chairman, Assistant to Commissioner, Department of Agriculture, State of South Carolina

Under the rules of general procedure of the Conference, the Director of the National Bureau of Standards, Dr. A. V. Astin, is the President of the Conference and IV. S. Bussey, Chief, Office of Weights and Measures, is the Executive Secretary of the Conference. In selecting the men for offices, as presented in this report, consideration was given by the committee to several factors, such as attendance records, geographical distribution, Conference participation, and interest in promoting weights and measures.

The Nominating Committce submits the following report, nominating for office for the 47th National Conference on Weights and Measures and to serve during the ensuing year or until such time as their successors may be elected:

Chairman: Robert Williams (Nassau County, New York).

liee Chairmen: Paul DeVries (Passaic, New Jersey); H. H. Houston (Colorado); F. F. Thompson (Loursiana); D. M. Turnbull (Seattle, Washington).

Treasurer: C. C. Mongan (Gary, Indiana).

Chaplain: R. W. Searles (Medina County, Ohio).

Exeeutive Committee: All of the officers and, in addition, the following: W. H. Cramer (New Jersey); H. E. Crawford (Jacksonville, Florida); R. I. Cummings (Altoona, Pennsylvania); A. H. Ditrricn (New Hampshire); G. L. Jounson (Kentucky); R. E. MIEeK (Indiana); D. R. PRatt (Santa Clara County, California); Raymond Rebuffo (Nevada); C. II. Wrenn (Danville, Virginia); Robert Zierten (Racine, Wisconsin).

\author{
C. H. Stender, Chairman \\ R. M. Bodenweiser \\ H. N. Duff \\ H. E. Howard \\ G. L. Johnson \\ H. J. MeDade \\ J. I. Moore
}

(There being no further nominations from the floor, nominations were dechared closed and the oflicers nominated by the conmittee were elected unanimously by voice vote.) 


\section{By. I. H. Lsws, Chiet. Weights and Measmes Section. Department of Agriculture. State of Washington}

i preholiday survey of checkweighings made of turkeys at the retail level in "Washington State stores made it evident that there was much to be desired to assure that the consumer was retting a firir deal in the purchase of turkeys. At the request of the Director of Agriculture, five teams of two men each took a comprehensive look at the net weight of turkeys exposed for sale during the preThanksgiving week in 195S. The conditions we found warranted a similar action prior to the Christmas-New Year season of that year. Our checkweighing inchuded both fresh and frozen turkeys. The checkweighing of fresh birds presented no particular problem. The checkweighing of the frozen birds was another matter. This brought up such questions as: How do you determine the tare on frozen turkeys? Is it fair to require the same tare for frozen birds as you find in the fresh birds? Should a large bird demand more tare than a smaller bird? Where is the reasonable dividing point between a small bird and a large bird? What are reasonable tares? How do we arrive at them?

Aftel some deliberation we decided the best way to get the answer was to go to the processors. After several contacts we were pleased with an invitation to make a survey in one of the intrastate processing plants. After a preliminary survey by Mr. Fred Mills, State Field Supervisor, and myself, we decided to make check weights at various points along the processing line. We were fortunate to be making our survey in a U.S. Department of Agriculture inspected plant. WTe received complete cooperation from the Federal inspector, who readily answered our questions concerning the process being used by this plant. We asked specifically whether they were using the usual and accepted method of processing frozen turkeys. Upon being assured that the plant was one of the best in the State, we felt we were on firm ground for our survey. After taking the necessary steps to attire ourselves in the required apparel to meet the sanitation requirements, we were ready to begin.

Our first step was the identification of the birds, so we could follow them through the complete process. This was done by tying a piece of white bias binding tape $3 / 4$ inch wide and 10 inches long to one leg of the eviscerated bird. This was long enough to allow the ends to dangle so the birds could be spotted as they were processed and passed along the drain chains and work tables. Each of the dangling tapes was numbered with a laundry pencil for individual identification. The positioned ourselves so we could pick birds at random from the line, make our markings and checkweighings, and place them back in the processing line for normal handling. 'The marked birds were placed in a separate chilling tank, but in all other respects were handled as the other birds.

Our first checkreight was made at the end of the drain line, where the birds passed from the eviscerating room to the chilling room. After marking and weighing the birds, they were placed in slush ice water to be chilled over night. I will have more to say about this 24 -hour soaking later in this paper. 
Our next checkweight was made the following morning as the birds were removed from the slush ice and after the water had been drained from the tanks for some 15 to 20 minutes. Our purpose here was to check the effectiveness of the drain line prior to packaging. We made no special effort to remore the clinging ice; nevertheless, by the time the birds were handled in weighing, there was very little evidence of ice on the birds.

We then moved quickly to the other end of the drain chain to check the reight after drainage.

The particular birds that were being processed were scheduled to be frozen and held for a later shipment to the firms' canning plant in Seattle. Arrangements were made for 10 of the 20 market birds to be placed in cartons and labeled so that they would not be opened until one of our inspector's could be present to weigh the birds as they came from the freezer to check the effects of cold storage. To better check the effect of freezing with respect to tissue breakdown, we permitted the processor to wipe the birds inside and out with paper towels to eliminate the excess moisture.

Thirty-six days later Mr. Mills opened the cartons in Seattle after they had been transported some 175 miles and held in storage.

The results of our survey, in pounds and ounces, are shown in tables 1 and 2 .

As a result of our various contacts and this survey, it was decided that a conference should be held with representatives of the turkey processing industry. An invitation was extended to all the known processor's in the State, as well as to certain of the nationwide firms who were shipping into our State. In the early spring of 1959 the conference was convened in Olympia to discuss the prepackage tare problem. Information disclosed that most processors would normally process either hen or tom turkeys at any one time, but not both in the same rum. It was agreed that there was a normal weight break at 18 pounds. In other words. there would seldom be a hen turkey that wonld run over 18 pounds, and most of the tom turkeys would exceed 18 pounds. As the result of our discussion we arrived at an agreed upon tare to be allowed on frozen turkeys. On hen turkeys or birds weighing up to and including 18 pounds, a 2 -ounce tare would be allowed, and on tom turkeys or those rumning over 18 pounds a 3-ounce tare was to be allowed. On the basis of what our survey teams had found in the field, the department felt this was a step in the right direction. I would like to add here that seasonal surveys conducted since this meeting have shown that in most instances onl processors have been living up to the established tares wonderfully well.

The fresh turkey situation was another matter. 'This did not present the problem to the weights and measures inspector that the frozen turkey did in that it was possible to determine the tare on the fresh bird. In hopes that further study of processing wonld disclose a reasonable tare for fresh turkeys, we continued our plant survey.

Due to the various factors such as drain time, transportation time and distance, shelf life, and normal weepage, it was found that in the fresh turkey field it was best to treat this commodity as we 


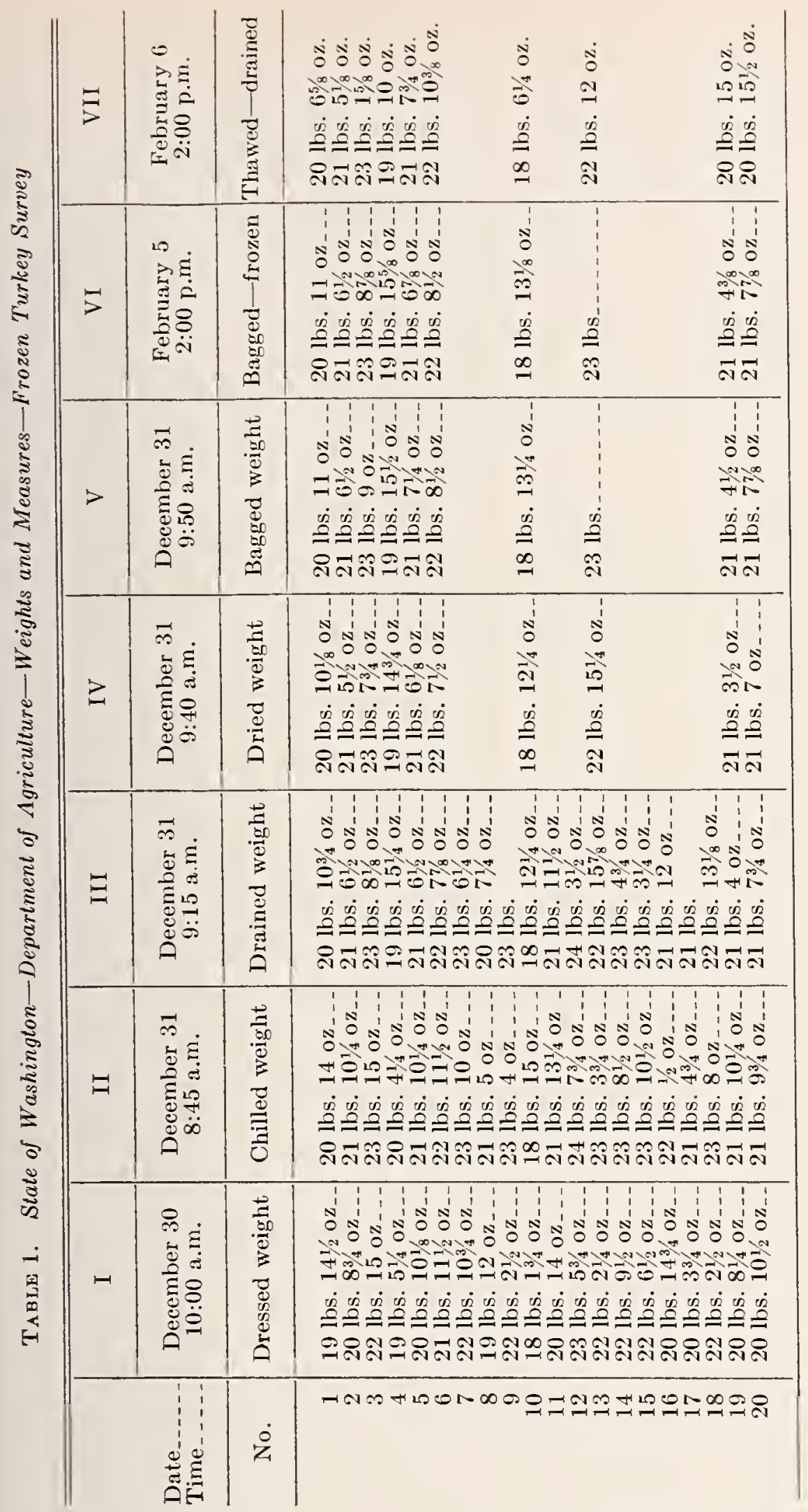




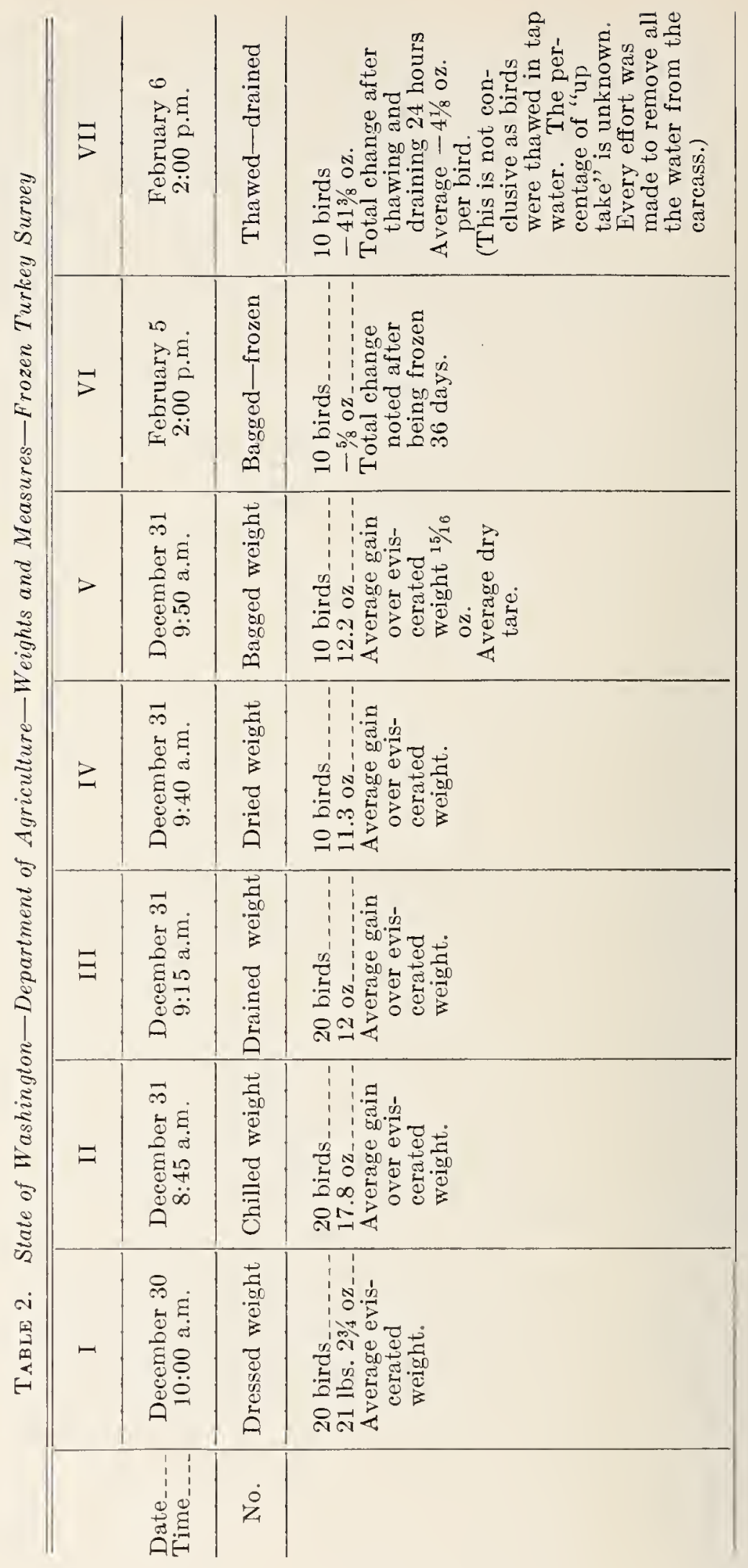


would any other prepackaged commodity ou which a tare could be established at the time of inspection. (See tables 3, 4, 5.)

I an sure nuy first reaction of incredibility to the results of the 2t-hour soaking process was one that has been experienced by a great number of weights and neasures people. The first conclusion was that it must be a local method with the solution to the problem being the respousibility of our own jurisdiction. Upon learning the slush-ice-water tank bath was an accepted method, we then tried to determine why. It did not take much research to learn that the U.S. Department of Agriculture, in their "Regulations Governing the Inspection of Poultry and Poultry Products" (Title 7, chapter 1, subchapter D, Part $\$ 1$, sec. $\$ 1.50$ ), set up certain requirements and standards for chilliug poultry of various weights. Birds under 4 pounds must be chilled to $40^{\circ} \mathrm{F}$. or lower within 4 hours; birds 4 to $\mathrm{S}$ pounds to the same temperature or below within 6 hours; and those over $S$ pounds within $S$ hours.

This section also provides that such poultry shall be maintained at $t 0^{\circ} \mathrm{F}$. or below until remored from rats or tanks for immediate packaging. It further provides that "Poultry which is to be held in chilling tanks in excess of $2 t$ hours shall at the end of the 24 -hour chilling period be removed from the tanks and repacked in clean ice in clean tanks which are continually drained, or as an alternative, the tanks shall be drained and re-iced and placed in a cooler which will maintain all of the poultry in the tank at a temperature of $40^{\circ} \mathrm{F}$. or below."

Still suffering from our first reaction, we felt there must be some reason why this method, which induced moisture, was acceptable by the U.S. Department of Agriculture and the Federal Food and Drug officials who are concerned with adulteration. Sanitation requires the ise of only potable water in the chilling process which possibly precludes any inference of adulteration.

Tre appealed to our Washington State University for assistance in this matter. and they fumished us with reports of studies made by a team made up of Spencer, Matson and Stadelman of the University and M. C. Ahrens of the U.S. Department of Agriculture. These three reports were entitled:

1. The Effect of Cooling and Freezing Procedures on Consumer Acceptability Factors of Turker Meats.

2. Cooling and Freezing Pan-ready Turkeys.

3. Poultry Meat Cooling and Freezing Study.

There was au additional report on "Cooling and Freezing Characteristics of Eviscerated Turkeys" made by a team consisting of Spencer, Matson, Eklund and Sauter.

These reports compared the relative end results of such chilling methods as:

1. Ice water.

2. Drained snow.

3. Air-cooled birds wrapped in wet canvas shrouds (chilled in walk-in forcedair cooler at $34^{\circ} \mathrm{F}$.).

4. Air-cooled birds in polyethylene bags (chilled in walk-in forced-air cooler at $34^{\circ} \mathrm{F}$.).

5. Quick freezing treatments in a walk-in freezer with unit blower and eraporator. These were checked at three different temperatures: $0{ }^{\circ} \mathrm{F} .,-20{ }^{\circ} \mathrm{F}$., and $-40^{\circ} \mathrm{F}$. 


\begin{tabular}{|c|c|c|c|c|}
\hline 胥 & $\varrho$ & 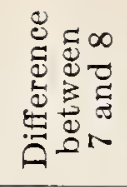 & 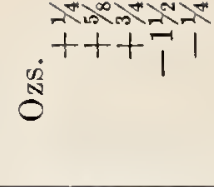 & $\left|\frac{1}{1}\right| 1 \mid$ \\
\hline 胥 & 0 & 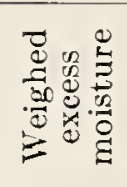 & $\int_{0}^{\infty}$ & 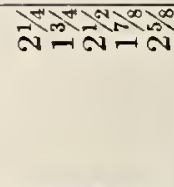 \\
\hline 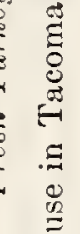 & $\infty$ & 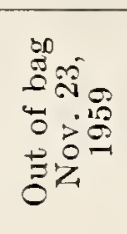 & 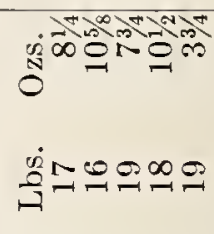 & 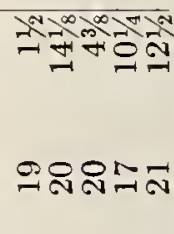 \\
\hline 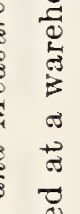 & N & 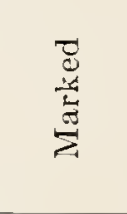 & 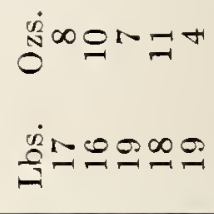 & $\begin{array}{l}\text { NOLニ } \\
\text { のே๐ニ }\end{array}$ \\
\hline 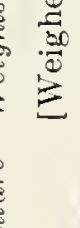 & 0 & 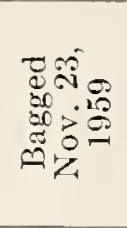 & 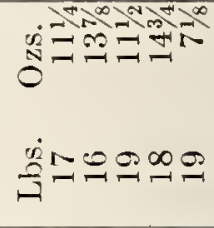 & 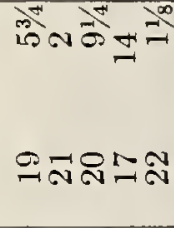 \\
\hline $\begin{array}{l}\frac{8}{80} \\
0 \\
-1 \\
i\end{array}$ & 10 & 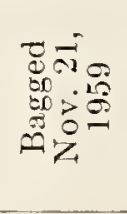 & 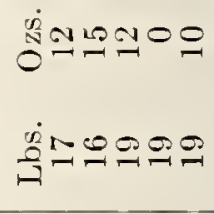 & 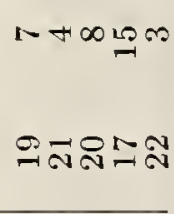 \\
\hline 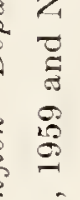 & + & 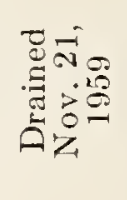 & 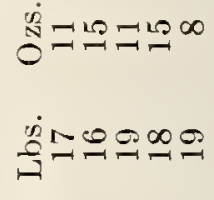 & 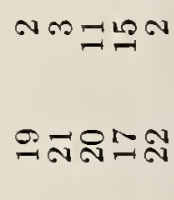 \\
\hline 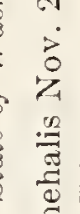 & $\infty$ & 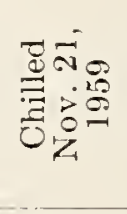 & 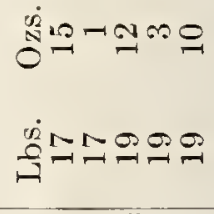 & 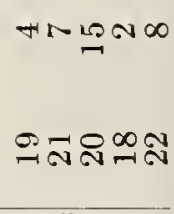 \\
\hline $\begin{array}{l}0 \\
0 \\
0 \\
0 \\
0 \\
00 \\
0 \\
0 \\
0 \\
0\end{array}$ & o) & 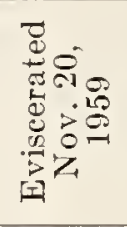 & 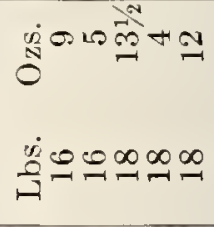 & 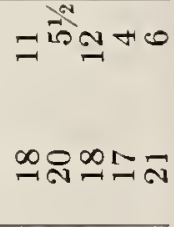 \\
\hline \begin{tabular}{l}
2 \\
0 \\
0 \\
0 \\
0 \\
\multirow{0}{0}{}
\end{tabular} & - & 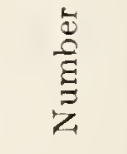 & & o \\
\hline
\end{tabular}




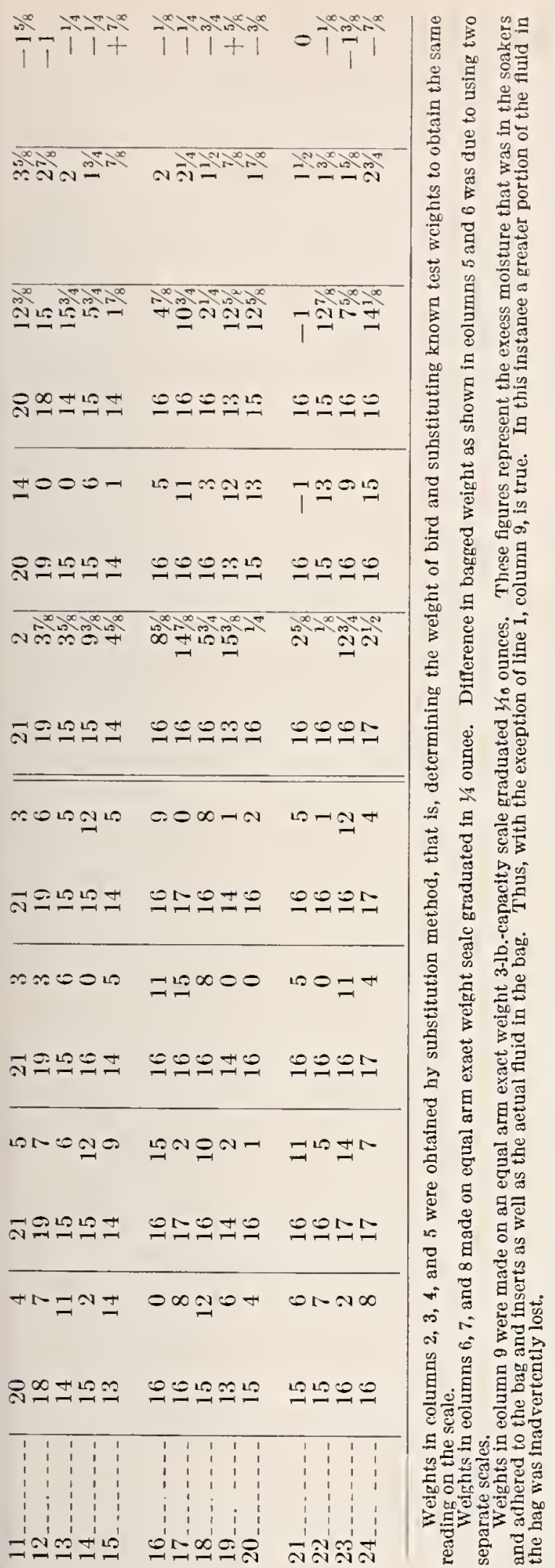


TABLE 4.-State of Washington-Department of Agrieulture-IVeights and Measures Section-Fresh Turkey Survey

The birds listed below were killed on November 18, 1959, processed and shipped November 19.

These birds were transported 380 miles and were cheeked at a warehouse in Spokane on November 23.

\begin{tabular}{|c|c|c|c|c|c|}
\hline \multirow[t]{2}{*}{ Number } & \multicolumn{2}{|c|}{$\begin{array}{l}\text { Marked } \\
\text { weight }\end{array}$} & \multicolumn{2}{|c|}{$\begin{array}{l}\text { Weight out } \\
\text { of bag }\end{array}$} & \multirow{2}{*}{$\frac{\begin{array}{c}\text { Tare } \\
\text { weight } *\end{array}}{\text { Ozs. }}$} \\
\hline & Lbs. & Ozs. & Lubs. & Ozs. & \\
\hline 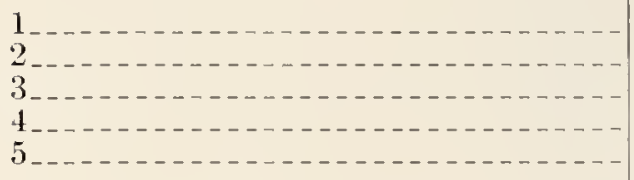 & $\begin{array}{l}17 \\
17 \\
17 \\
16 \\
17\end{array}$ & $\begin{array}{r}5 \\
13 \\
9 \\
4 \\
11\end{array}$ & $\begin{array}{l}17 \\
17 \\
17 \\
16 \\
17\end{array}$ & $\begin{array}{c}41 / 4 \\
11^{1 / 4} \\
91 / 2 \\
5 \\
10^{3 / 4}\end{array}$ & $\begin{array}{l}47 / 8 \\
61 / 2 \\
53 / 4 \\
4 \\
41 / 2\end{array}$ \\
\hline 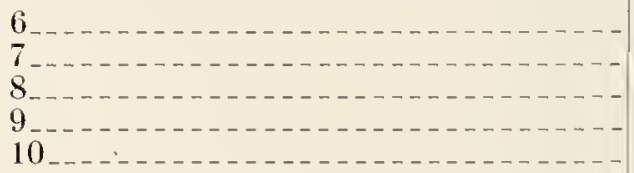 & $\begin{array}{l}16 \\
14 \\
14 \\
17 \\
17\end{array}$ & $\begin{array}{r}4 \\
8 \\
15 \\
10 \\
8\end{array}$ & $\begin{array}{l}16 \\
14 \\
14 \\
17 \\
17\end{array}$ & $\begin{array}{l}51 / 4 \\
4 \\
121 / 2 \\
81 / 2 \\
6\end{array}$ & $\begin{array}{l}33 / 4 \\
71 / 2 \\
5 \\
61 / 4 \\
61 / 2\end{array}$ \\
\hline
\end{tabular}

* The tare weight was established by aetually weighing the wet bag, soakers and inserts.

TABLE 5.-State of Washington-Department of Agriculture-Weights and Measures Section-Fresh T'urkey Survey

Survey made in Seattle, Washington, December 16, 1959 at a processing plant

\begin{tabular}{|c|c|c|c|c|c|c|}
\hline Number & $\begin{array}{c}\text { December } \\
16,1959 \\
\text { Eviscer- } \\
\text { ated }\end{array}$ & Chilled & Drained & $\begin{array}{l}\text { With } \\
\text { giblets }\end{array}$ & Bagged & Marked \\
\hline $1 \ldots$ & $25-1$ & $25-157 / 8$ & $25-123 / 4$ & $26-121$ & $26-12^{3 / 4}$ & $26-7$ \\
\hline & $20-123 / 4$ & $21-123 / 4$ & $21-87 / 8$ & $22-71 / 2$ & $22-8$ & $22-3$ \\
\hline & $23-4$ & $24-23 / 4$ & $23-105$ & $24-9 \%$ & $24-10^{3}$ & $24-6$ \\
\hline & $21-51 / 8$ & $22-21 / 4$ & $21-15 \%$ & $22-13 \%$ & $22-141 / 4$ & $22-9$ \\
\hline 5 & $23-11$ & $24-123 / 4$ & $24-61 / 4$ & $25-4 / 4-$ & $25-5$ & 25 \\
\hline 6 & $20-12 \%$ & $21-13^{3 / 4}$ & $21-71 / 1$ & $22-6^{3 / 8}$ & $22-71 / 8$ & $22-2$ \\
\hline & $21-14^{3}$ & $22-135 \%$ & $22-10^{3 / 4}$ & $23-71 / 4$ & $23-81 / 8$ & $23-3$ \\
\hline 8. & $24-2$ & $25-53 / 8-$ & $24-13 \frac{1}{8}$ & $25-10^{7 / 8}$ & $25-117 / 8$ & $25-6$ \\
\hline $9 \ldots \ldots$ & $25-2$ & $26-1$ & $25-12$ & $26-101 / 4$ & $20-103$ & $26-5$ \\
\hline $10 \ldots \ldots$ & $15-31 / 2$ & $16-1 / 4 \ldots$ & $15-131 / 4$ & $16-11$ & $16-97 / 8$ & $16-7$ \\
\hline 11 & $20-11 / 4$ & $20-125 \%$ & $20-10^{1 / 2}$ & $21-7 / 1 / 2$ & $21-87 / 8$ & $21-4$ \\
\hline $12_{-}$ & $19-125$ & $20-91 / 2-$ & $20-73 / 8$ & $21-65 \%$ & $21-71 / 2$ & $21-2$ \\
\hline $13 \ldots$ & $12-2$ & $12-10^{1 / 4}$ & $12-75 / 8$ & $13-47 / 8$ & $1: 3-6^{1 / 8}$ & $13-2$ \\
\hline 14 & $11-121$ & $12-37 / 8$ & $12-23 / 8$ & $12-145 / 8$ & $12-15$ & $12-11$ \\
\hline $15 \ldots$ & $12-91 / 4$ & $13-13 / 4$ & $12-141$ & $13-91 / 2-$ & $13-10^{3 / 8}$ & $13-6$ \\
\hline $16_{-}$ & $12-6 \%$ & $12-13$ & $12-10$ & $13-61 / 4$ & $1: 3-71 / 2$ & $13-4$ \\
\hline & $12-37 / 8$ & $12-123 / 8$ & $12-105 / 8$ & $13-6 \ldots$ & $13-7^{1 / 8}-$ & $13-3$ \\
\hline 18. & $12-127 / 8$ & $13-55 / 8-$ & $13-17 / 8$ & $13-131 / 2$ & $13-14^{1 / 2}$ & $13-10$ \\
\hline 19 & $13-4$ & $13-123 \%$ & $13-101 / 8$ & $14-71 / 8-$ & $14-81 / 8$ & $14-4$ \\
\hline $20 \ldots$ & $11-7 \ldots$ & $11-153 / 4$ & $11-11 \frac{1}{4}$ & $12-77 / 8-$ & $12-71 / 8$ & $12-5$ \\
\hline 21 & $11-3 \frac{3 / 4}{4}$ & $11-10 \frac{5}{8}$ & $11-93 / 4$ & $12-4^{5 / 8}$ & $12-5^{1 / 2}$ & $12-1$ \\
\hline 22 & $11-13 \frac{1}{2}$ & $12-47 / 8$ & $12-33 / 8$ & $13-1 / 2$ & $13-13 / 4$ & $12-14$ \\
\hline & $13-6^{1 / 4}$ & $13-151 / 8$ & $13-13 \frac{1}{8}$ & $14-123 / 1-$ & $14-131 / 2$ & $14-10$ \\
\hline 24 & $12-14^{1 / 2}$ & $13-67 / 8$ & $13-4 \ldots$ & $13-15^{3 / 4}$ & $14-1 / 2 \ldots$ & $13-12$ \\
\hline
\end{tabular}


Charts were made to show the comparison of the different methods with relation to (1) cooling and freezing rates, (2) rating of grencal appearance. (3) tenderness, (4) percentage change in weight from tresh bird to cooked bird, and (5) percentage of weight lost during thawing and cooking.

Based on these studies, the final analysis would indicate the consumel is better served by receiving a palatable, tender, nice-looking bird even when a weight change is involved. The trend to accepting reasumable variations when caused by ordinary and customary exposure to conditions that normally occur in good distribution practice and muroidably result in change of weight or measure points to the fact that practicability sometimes supersedes holding fast to a net weight concept. I am sure the processors anywhere will admit that there is an indnction of moisture when the tank chill method is used; but they will fight to the bitter end for their right to use an accepted procedure which will produce the best marketable product.

I am as concernet as anyone that the added water costs the housewife the same price as the turkey, and I am convinced that, until a better method of chilling and preparing frozen poultry is developed, my responsibility is to see that she is forced to buy as little water as possible. This demants continued checkweighing on a spot-check basis at processing plants that are freezing poultry, as well as an inspection of the effectiveness of their drain lines. I believe it is part of reights and measures responsibility to work with accepted procedures to the end that "equity may prevail."

We have concluded that, until a more desirable method of chilling poultry is dereloped, we will live with the slush-ice-water bath method. From a weights and measures standpoint, the only redeeming feature that we find in the added weight taken up by the birds is the fact that in our State most of the producers are paid on the basis of "packed out" weight. From a merchandising standpoint, we can understand that it produces a better marketable bird.

The most valuable product of the effort we spent in our surveys was the mutual respect gained between the processor and the weights and measures officials. We learned a great deal about their problems, and I am sure we earned a deeper respect from them for the job we were trying to do. This is another area where modern processing methods point out the fact that demands on weights and measures personnel are more exacting. The moder'n trend in merchandizing is removing the black and white decisions farther and farther into the background. It is no wonder the oldtimers cling tenaciously to the "net-weight" concept. Sometimes these decisions without clear-cut lines are difficult indeed.

As reights and measures officials we must be willing to grow in stature to meet the demands of modern merchandisiug. This will require a certain amount of flexibility and still not lose sight of the prime purpose of our service to our fellow man.

\section{DISCUSSION ON FOREGOING PAPER}

Mr. Robinsox: Are there any questions?

Mr. Rebufro: Mr. Lewis, your studies indicate that you find 3.6 percent of the moisture increase is reasonable. In view of that fact, 
what is your thinking of the proposal of USDA to consider a 10 percent moisture allowance in packed poultry?

Mr. Lewis: It is true that in a 21-pound $23 / 4$-ounce turkey we found that the average takeup of 12 ounces indicates an increase of some $3 \frac{1}{2}$ percent. TVe also must recognize that there are other processes being used at the present time which induce considerably more moisture than the ice-slush bath.

It would seem to me, however, that when we get into the area of permitting 6 percent on a 5 -pound chicken, unless there is a biological reason why chickens will absorb more water than turkeys, it possibly is excessive, even in view of the other types of chilling.

Mr. Fensstex: Mr. Lewis, that was an excellent paper and it bears out some of the things we have discovered in Alameda County, California. In your paper you referred to allowing the packer to wipe the bird inside and out. I was curious about that. Your explanation and the chart helped to develop what difference occurred and it appears to me that we must then add 0.7 ounce to your final tare. That will give you your normal tare for normal packaging practice. Iou mentioned this was done to determine the tissue breakdown and I did not hear any other reference to the result of that.

Mr. Lrwis: Mr. Fernsten, there had been some indication to us that birds held in a frozen state have some tendency to lose moisture, even though they may be packed in polyethylene bags. Possibly you may recall that we found that in birds that were held some 36 days in a frozen state, the gross change, the total change in the gross weight for all tell birds, was only five-eighths of an ounce. That was one of the things we were trying to determine, whether there was actually any change due to evaporation or tissue breakdown in a frozen state which was negligible.

Mr. KinswetT: With your permission, I would like to make a statement regarding the Department's moisture tolerances for poultry. Tre have done considerable study on the moisture problem, with particular emphasis on these new continuous chilling devices which Mr. Lewis mentioned. We want to compliment him on the paper that he has just presented. The have similar problems and have conducted the same type of testing that he reported.

With respect to the different tolerances which are allowed for the various sizes and classes of birds, we have found that frying chickens absorb more moisture than do heavy turkeys when chilled by the same system. Fryers weighing from 2 to $2 \frac{1}{2}$ pounds will absorb about 8 percent, heavy turkeys about $41 / 2$ percent, 4 to 6 -pound turkeys about 8 percent, and 10 to 12 -pound turkeys about 6 percent.

We are not sure why this occurs. Maybe the smaller birds are not as well fleshed or covered with fat, but nevertheless this is what happens when different types of poultry are chilled in the same manner.

We use as our standard the amount of moisture which is absorbed when chilling is done by the conventional chill tank system, and our tests are conducted exactly as Mr. Lewis explained, with the exception that we weigh birds prior to the first washer and the moisture absorbed as a result of the washer is included in the tolerances. 'Therefore, our tolerance of $4 \frac{1}{2}$ percent on heavy turkeys 
is in line with the $31 / 2$ percent which Mr. Tewis reported on, since the washing process, which is not included in the $3 \frac{1}{2}$ percent, would raise the moisture figmre to $41 / 2$ percent.

The Department s policy is to allow plants to use any chilling system they desire, so long as the system does not result in the absorption of moisture in excess of the permitted tolerances which are based on standard chill-tank chilling.

Mr. Lruss: Mr. Lewis, have you issued specific instructions to your inspectors as to what tolerances to allow in the checkweighing of frozen turkeys in supermarkets at retail and at the wholesale level?

Mr. Lewis: With reference to tolerances, no, we leave that up to the inspector; however, with respect to tare-

Mr. Lrues: 'That is what I meant.

Mr. Lewrs: You might be interested to know that our initial surreys, which actually sparked our field survey and in turn sparked the plant survey, showed there were a number of instances where no tare was allowed. There were a number of instances where probably a half ounce was allowed. Actually, at the present time, as our mein go into the field to checkweigh frozen birds, their instructions are to follow the tares that they establish with the processors, which were 2 ounces on birds up to and including 18 pounds and 3 ounces on birds 18 pounds or over. And we used those right down the line, and we found that the processors comply very readily with these tares that were established.

Mr. BrackburN: Mr. Lewis, the point has been raised on this 2t-hour soaking period-within the last 10 days we made a tour of our turkey processors, not in the chicken field but in the turkey processors, which did the freezing of these same birds.

Incidentally, their line processors are using the brine freeze process after the draining period. We were wondering if all of the processors are using a 24 -hour soak. These processors report to us on a full day's production that they start their killing in the morning and are starting their actual packing operation after the soaking period after about a 5 -hour period. On their half-day operations they are killing in the afternoon, packing the next morning, which is resulting in about an 18-hour soaking.

Incidentally, the tare weights which Mr. Lewis has mentioned a couple of times seem to be pretty well in line with those which we have found within our jurisdiction.

Mr. Lewis: Would you restate your question please?

Mr. BrackвURx: We were wondering if the plants are tending in your areas to operate on a 24 -hour soaking basis in their tank-slush process for the coming year.

Mr. Lewis: I think we have to recognize the fact that a great number of plants are going to the new type of processing, which is the tumbling or spinning type, and actually it is to cut down overhead, and so forth. There are a number of plants in our State that are still using the slush-ice-water bath tank method.

But naturally they are cutting down overhead. They are going into these spin-chilled, tumble-type chills. They are inducing more moisture, and it is becoming more and more of a problem, plus the fact that there are some instances where smaller birds are in the chicken processors. We find they are prone to place these spin- 
chilled chickens right into the freezer. They are freezing quite a lot of excess moisture, we feel, in the bird, so we are far from out of the woods on the problem. It is something we have to keep under constant surveillance.

Mr. Raymund: Mr. Lewis, why do they use such a drain line? Why could not the drain line be extended and drain the turkey better before it is packed? I notice that some of the packing plants that we have been in have the turkey on the drain line a very few minutes before it is put on a scale and weighed. Why not have a longer drain line? Would not that affect it?

Mr. Lewis: We feel in Washington that very definitely it will affect it. We feel it would be well in all instances to be sure that the drain line is of adequate length, and I might say here that in the surveys we ran we found that there was quite a difference in the length of the drain line. As indicated in my final chart, when-there was a mechanical failure in the Seattle plant and the birds were on the line probably twice as long as they normally would be, they found quite a definite difference in the amount of moisture or the actual uptake, indicating that there is an additional drainage.

Of course, they have their problems, naturally. There is a point there somewhere they feel they have reached the maximum drainage, but we definitely feel that longer drain lines are quite desirable and probably might be worth consideration of the Federal people in their regulations to establish a minimum drain period.

\section{BREAD TOLERANCES}

\section{By W. M. Schiri, Maintenance Instructor, American Institute of Baking, Chicago, Illinois}

Bread has been, and is today, an important part of man's daily diet. Through the centuries the mysteries of wheat flour have challenged man's quest for an answer to its endless variables and nutritional abundance. The ancient baker and his modern counterpart have learned that bread's basic and principal ingredient, wheat flour, is as variable as are the forr seasons and is as impossible to predict. Yet, the baker, in order to achieve the distinct character, quality, and uniformity of his product, must continually face the challenge of flour rariables by adjusting flour blends, bread formulas, and machine settings. This requires the skill of a craftsman and the talents of the scientist and laboratory technician which when combined is frequently referred to as the "art of baking." My mission is to tell you something of these variables and some of the complexities and limitations in controlling them.

At the outset, let me define the baker's position clearly in regard to his attitude on the proper and uniform weight of his bakery products. No one recognizes more than does the baker that accurate weighing and measuring devices are essential to producing quality products at efficient levels. Weight inaccuracies represent waste and lack of production control that eat into profits and may even lead to financial ruin. However, the answer to uniformity, quality, and weight control is not solved by accurate scaling and measuring devices alone. Every machine and process in the baking production 
line can contribute to variables which will aflect the total character of his product.

By no means will I attempt to cover the entire scope of baking variables, and how they contribute to rarying the end products and their weights. Instead, I will confine my discussion to the principal areas that affect miformity and weight control.

First, let us acquaint ourselves with the process of baking bread. Basically, there are two commonly used systems for baking bread. One is cilled the Straight Dough Method and the other is called the Sponge Dough. Wethod.

The Straight Dough Method is a one-step system in which all of the ingredients are mixed together in one single operation.

The Sponge Dough Method requires two distinct steps which involve, first, the mixing of a part of a dough consisting of 50 percent to 75 percent of the total flour, the yeast, malt, and enough water to result in a stiff spongy dough. The sponge is then allowed to ferment from 2 to 5 hours (depending upon the formula and product requirements). After fermentation has begum, the sponge or dough remains live and contimmes to ferment through each process and machining stage until it reaches the second chamber in the baking oren. It is this live action of fermentation that must be closely controlled by precision control of time and temperature if the prodnct is to be desirable and uniform. From the fermentation room the sponge is retumed to the mixer, where the shortening, milk, sugars, salt, and other ingredients are added and mixed into a final dough stage.

This paper will not concern itself with other systems of breadmaking, but will confine its discussion to the Straight-Dough and Sponge-Dough Systems, since these are the most commonly used.

The area of greatest concern for the machinability of a dough to accomplish a uniform product of standard quality and weight is the "makeup" area. The names and functions of the machines in this area are, in their order, as follows: The Dough Divider cuts the dough into defined sizes; the Rounder kneads and rounds the dough pieces; the Intermediate Proofer provides a short resting period for further fermentation and derelopment to prepare the dough pieces for final machining through the molder, where they are sheeted, rolled, formed, and put into pans. This is a completely mechanized operation that consistently demands a dough of uniform mass, texture, grain, gas distribution, and structure. Almost every rariation of a dough's character will effect a change in the settings and the products of these machines. The most sensitive to these variations, as it affects final dough weights, is the Dough Divider. It is this machine upon which the baker depends for minimum variations of final loaf reights.

In order to appreciate and understand something of the conditions factoring the weight rariables in the finished loaf, and the limitations for their control, we must know something of the complexity of dough derelopment and the principle of operation of the Dough Divider.

To obtain a properly mixed dough, it is necessary that complete attention and control be given to correct formula balance, weighing of all ingredients, blending, temperatures, and time cycles. Proper mixing of a dough cannot be obtained if the fermentation and the 
absorption of the dough are allowed to vary. Doughs properly fermented and mixed will have a balance of gas production and gas retention. The miform dispersion of these "bubbles of gas" throughout the dough structure is vital to the proper machining of the dough piece and the appearance and uniformity of the finished product. Gas production affects quality, flaror, volume, and weight uniformity. Gas retention is the ability of the dough piece to retain the gas produced in fermentation. It must be remembered that, once the highly complex system of fermentation has begum, the dough becomes a living mass undergoing continual expansion. The rate of expansion of a dough is dependent on the rate of gas formation due to fermentation and the permeability of the dough which permits some of the gas to escape. Fermentation rate itself is dependent upon many factors, including temperature, the amount of moisture in the dongh, the concentration of water soluble materials such as salt and sugar, the supply of mutrients which is controlled by enzyme systems outside the yeast cell, and finally the elaborate series of enzymatic reactions within the yeast cell required to convert a simple sugar into carbon dioxide and alcohol.

Since the yeast produces heat by its action, the temperature of the dough is dependent not only upon the external temperature, but also on yeast activity. The retention of gases by the dough is dependent upon factors not yet understood which seem to influence the permeability of the cell walls.

A dough in which the gluten has attained a state of maximum gas retention, elasticity, and springiness is considered mature, but as previously stated this is not a static condition and, if the time and temperature factors are not closely controlled and adhered to, this changing mass of dough will continue to change markedly. The closer the time and temperature factors are controlled, the narrower will be the margin of rariation of dough character and density.

"The Dough Divider is designed to "scale" dough pieces by volume. In order to do this, the dough must be fed to it at a constant rate. If the dough had uniform density and elasticity from the beginning of the batch to the end of the batch, precision at the divider could be obtiined. However, because of the rariable elements of dough development and the factors of fermentation, we must accept an ever changing condition of dough character, density, and elasticity. This requires continnous checking of dough weights on a scale and continuous correction of the volume control of the divider pockets and pistons by the operator.

Figure 1 shows a Dough Divider of a type used in the production of breads for wholesale distribution. 'This is a 5-pocket divider with a variable speed capacity $u p$ to 20 strokes per minute. For each stroke the 5 pockets and pistons will measure and cut 5 pieces of dough of a set volume as determined by the dough weight required and the domgh density. 'Thus the operating speed of this divider may be as high as 100 pieces per minute and may be as little as 50 pieces per minute. Dividers are constructed in sizes of from one pocket to as many as 8 pockets per machine, with speeds as high as 25 to possibly 30 strokes per minute, or 200 to 240 pieces of dough per minute. In this illustration the Dough Divider is shown equipped with an automatic Dough Hopper Gate Control. A batch of dough delivered to this hopper would weigh perhaps 1,600 pounds, 


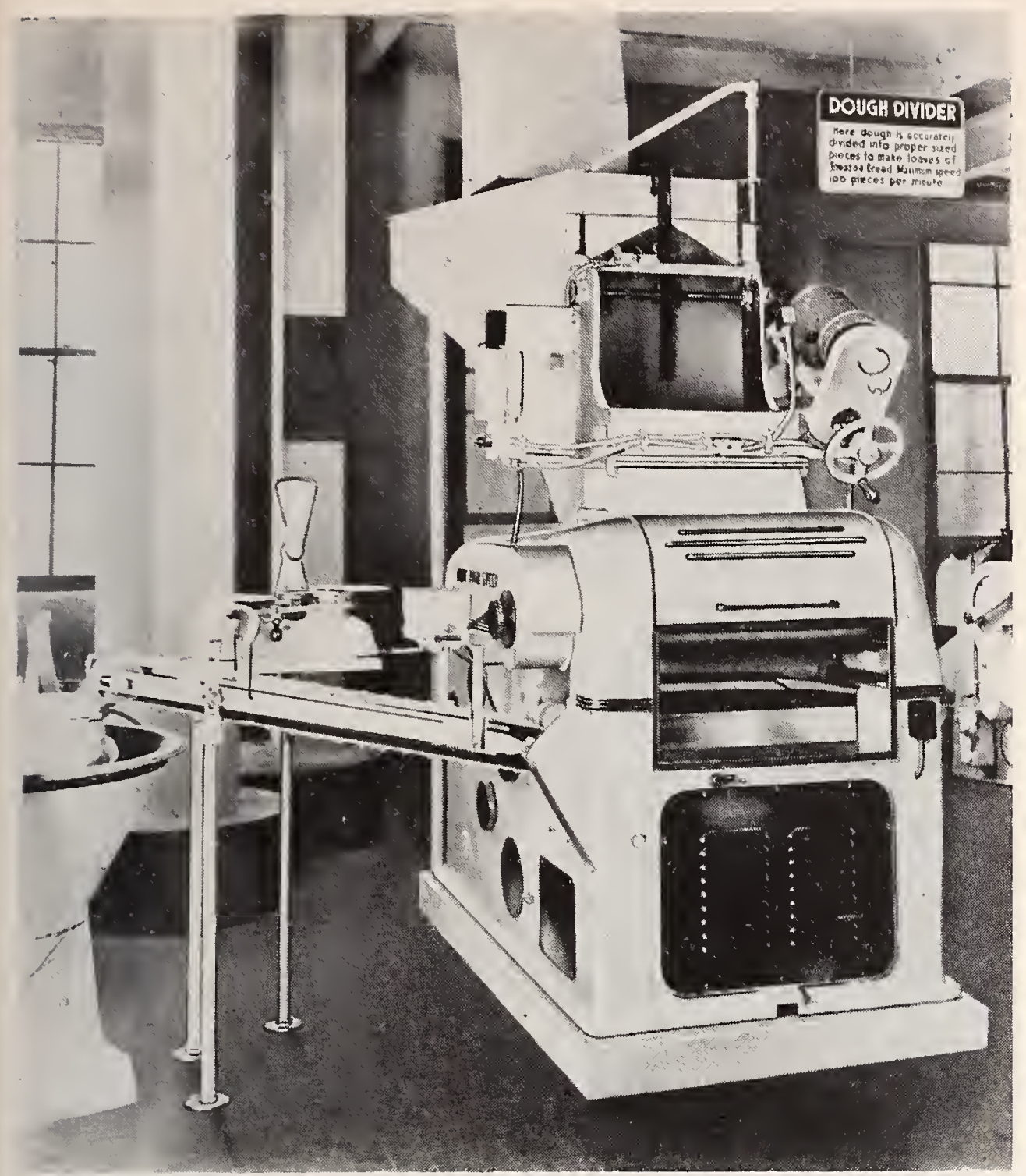

Figure 1. Dough divider.

and the gate is designed to modulate up and down so as to keep the dough feeding into the Divider Hopper flowing at a constant rate and pressure. 'The divider scale for spot-checking the actual weights of the dough pieces is conveniently located at the discharge side of the machine.

In Figure 2 the Divider Pistons are clearly shown. This is an 8-pocket divider with a capacity of 200 dough pieces per minute. The range of dough-piece sizes may be as small as 8 ounces to as large as 36 ounces of dough of average density. Each of the divider pistons may be individually adjusted so that all pockets will scale equally within the design and operating limits of the machine.

Figure 3 is a drawing of a side view of a basic Dough Divider whose primary function is to divide equally a dough into pre-set volumes or weights per pieces. Keep in mind that the density of the dough will determine the volume of the individual dough piece. 


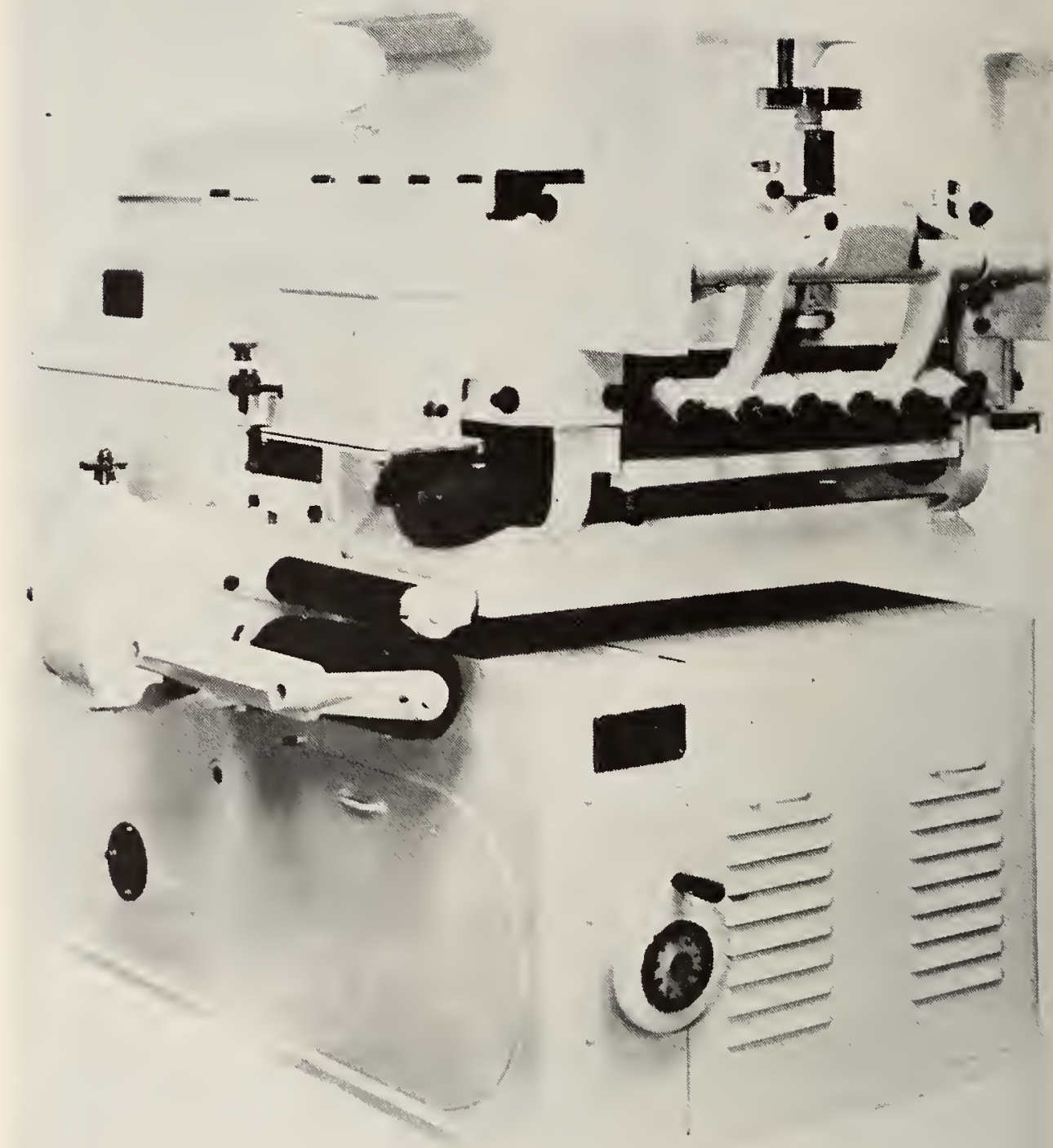

FIGURE 2. Divider pistons.

The density of a dough is at its greatest at the start of each dough batch, and therefore the rolume of each piece is smaller than the dough pieces cut at the end of each batch, when the density is less as a result of the continued fermentation of the live dough. 'Thus, throughout the batch, dough pieces must be checked and adjustments for volume and weight nade.

The uniform volume of each dough piece from each of the divider pockets is dependent also upon the uniform flow and pressure into the dough chamber and the proper lubrication and slip of the dough into the chamber. 'This flow of the dough through the divider depends upon gravity and racuum. The vacuum is derived from the action of the ram and the seal supplied by the lubricant, the dough, and the closely fitter parts of the machine. The dough 


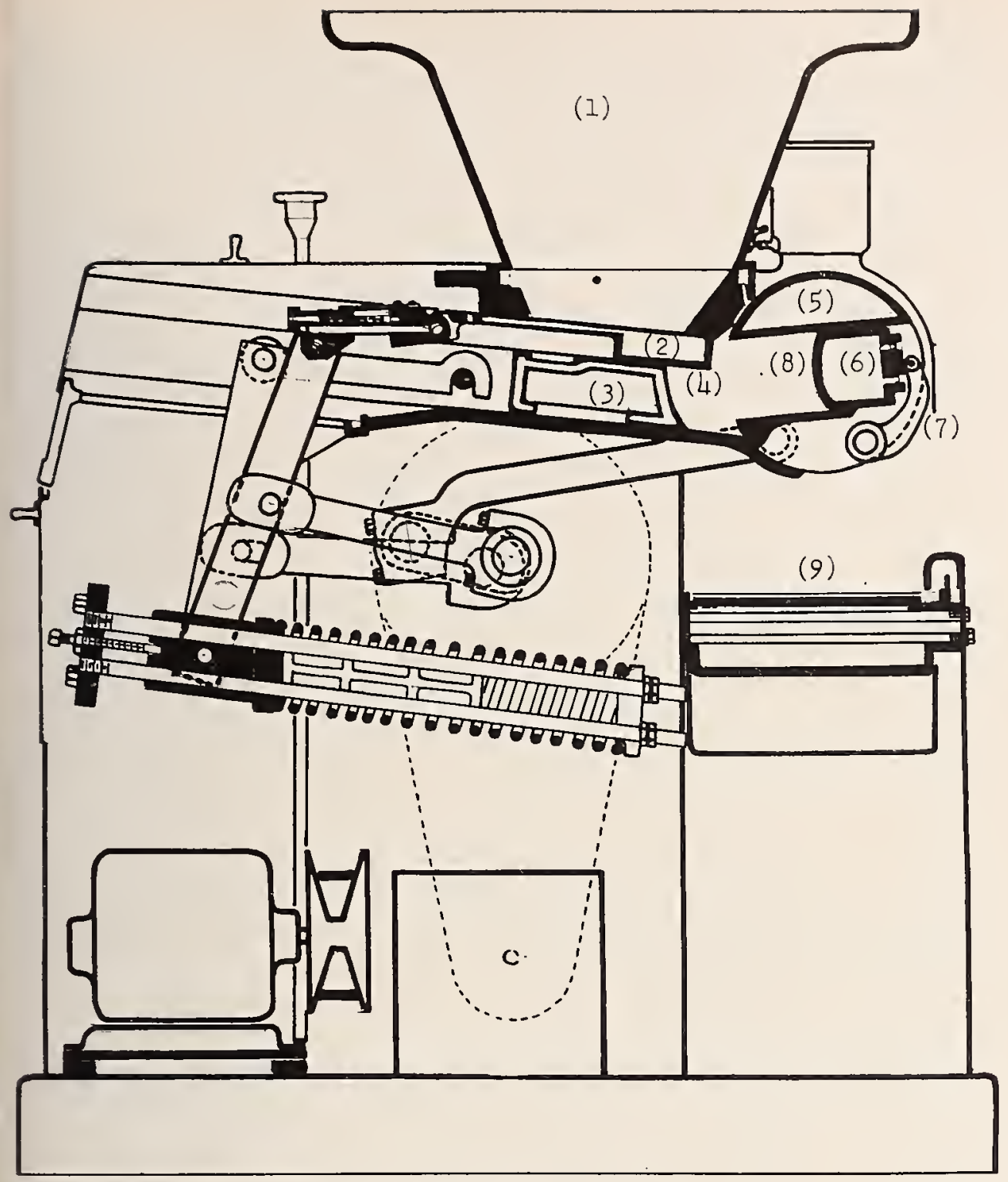

Figure 3. Divider-side view.
(1) Divider dough hopper
(2) Knife
(3) Ram
(4) Dough ehamber
(5) Rotary bead
(6) Piston
(7) Piston stop adjustment lever
(8) Pocket
(9) Conveyer

enters the divider hopper through the gate of the dough hopper and slides into the dough chamber when the knife and ram are at the open position. When the dough chamber is filled, the knife comes forward and cuts the dough and at the same time isolates the dough in the dough chamber from the dough in the divider hopper above it. Then the ram, with uniform pressure on the dough, moves forward to push the dough into the divider pockets to the pre-set rolume prescribed by the operator. For these pockets to be completely and uniformly filled, the dough must be uniformly distributed ahead of the ram. The gassy and spongy nature of the dough 
makes this difficult to accomplish becanse the filling of the dough chamber is dependent upon vacuum produced by the movement of the mass. After the pockets are filled, the dough is then sheared by the morement of the divider head. When the pistons are in a discharge position, the pistons will move formard into the pocket pushing the dough out onto the belt conveyor below.

The accuracy of the weight of each of the dough pieces so "scaled" is also limited by the mechanical condition of the divider parts and the uniform distribution in proper quantities of the divider oil lubricant. Loss of vacuum, or dough leakage due to poor lubrication or worn parts, will affect the accuracy and uniformity of the dough pieces. Higher speeds, necessitated by requirements for rolume production and lower manufacturing costs, also have an effect upon the "scaling" efficiency of the machine. At the higher speeds it becomes increasingly difficult for the operator to spot-check weights of the dough pieces and make machine corrections at the same frequencies that he could at the lower production speed levels.

To demonstrate the difficulty of accurate control of dough-piece weights as a result of these conditions native to the production of bread, one of our industry's large bakery operators made a study of finished and packaged bread weights as compared with the scaling weight settings at the Divider.

Table A shows the resnlts of a check on the final bread weights after packaging of 100 loaves produced at Plant "A." The label weight on the package was 24 ounces; the scaling weight at the divider was set for $271 \%$ onnces. The diriders and bread formulas in the studies made for each plant were the same. In this record we see a finished weight range from a high of 25 ounces to a low of $231 / 8$ ounces, with an average net of $241 / 8$ ounces for the 100 loaves.

Table B illustrates the results obtained in Plant " $B$ " for the same product. The high net weight recorded here was $247 / 8$ ounces and the low $231 / \mathrm{s}$ ounces, with an arerage net weight for the 100 loaves checked of 23.9 ounces.

'Table C shows the results of the check made at this company's Gulf Coast Plant "C." The net high for the finished packaged loaf recorded was $251 / 4$ ounces and the low was $233 / 4$ ounces, and the arerage net weight for the 100 loaves checked recorded as 24.67 ounces.

Table D records the findings of the tests made at their North Central Plant "D." The high net here was $251 / 2$ ounces and the low $233 / 4$ ounces, with a net arerage of $24 \%$ ounces for the 100 loaves checked.

It should be mentioned here that the baker must allow for further losses of weight in his product after dividing. These losses in the weight of a loaf of bread are cansed by the losses of vapors and gases due to additional fermentation occurring in the process of proofing. 'This is the process of the dough raising in the pan. Additional losses will occme in the "oven spring" or continued fermentation during the first stage of the baking process. Added to this is the moistmre loss due to the baking of the loaf, which the baker refers to as the "bakeont loss." "This is followed by the requirement for cooling the loaf from internal temperatures of $210^{\circ} \mathrm{F}$. down to $95^{\circ} \mathrm{F}$. for slicing and wrapping, which causes an additional loss of moistnre and aromatic vapors. These losses are variables too 
TABLE A

Welghts in ounces of 100 Joares selected at random from packaging room. Scaling weight $2-\pi, 50 z$. label weight $24 \mathrm{oz}$., baking time 24 mintutes in tray oren. Loaves weighed after wrapping.

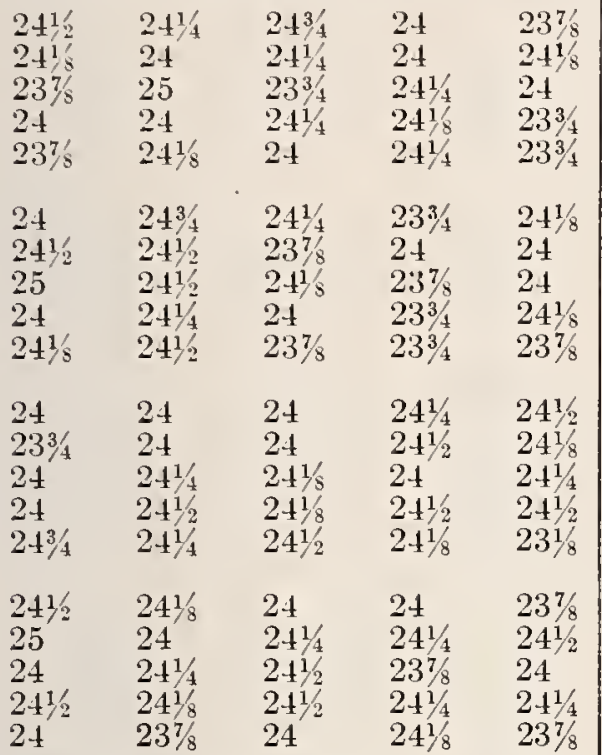

Weight of 100 loaves: 241538 ounees.

A rerage net weight per loaf: 2418 ounees.

\section{TABLE B}

Weights in ounces of 100 loaves selected at random from packaging room. Scaling weight $27 \mathrm{oz}$., label weight $1 \mathrm{lb} .8 \mathrm{oz}$., baking time 24 minutes in $110^{\prime}$ tunnel-traveling oven. Loaves weighed after wrapping.

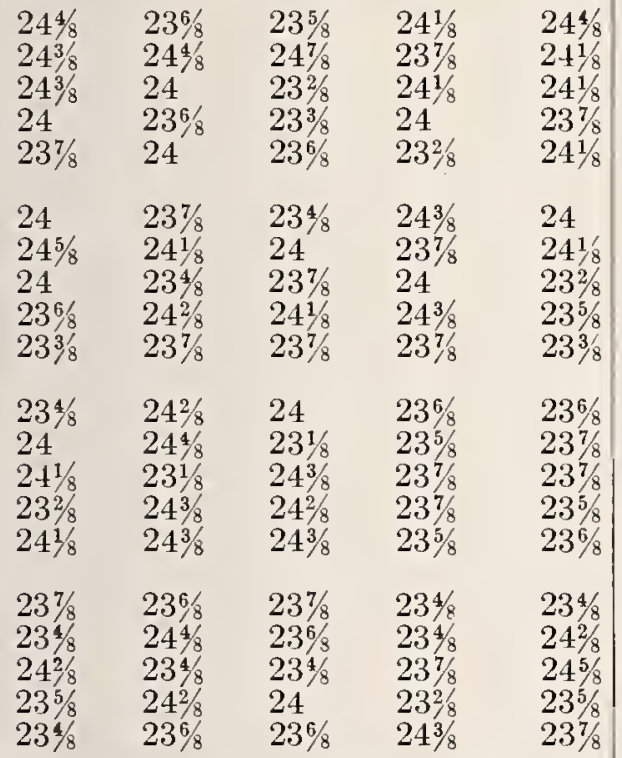

Welght of 100 loaves: $23907 / 8$ ozs. (149 lbs. 678 ozs.) Average net weight per loaf: $23.90875 \mathrm{ozs}$.
TABLe C

Weirhts in ounces of 100 loaves selecterl at randoun from packaging roou. Sealing weight $271,507 \mathrm{~s}$, label weight 1 lb. 8 ozs., baking time 2315 minutes in converted diathermetic oven to direet fire 34 tray. Loaves weighed after wrapping.

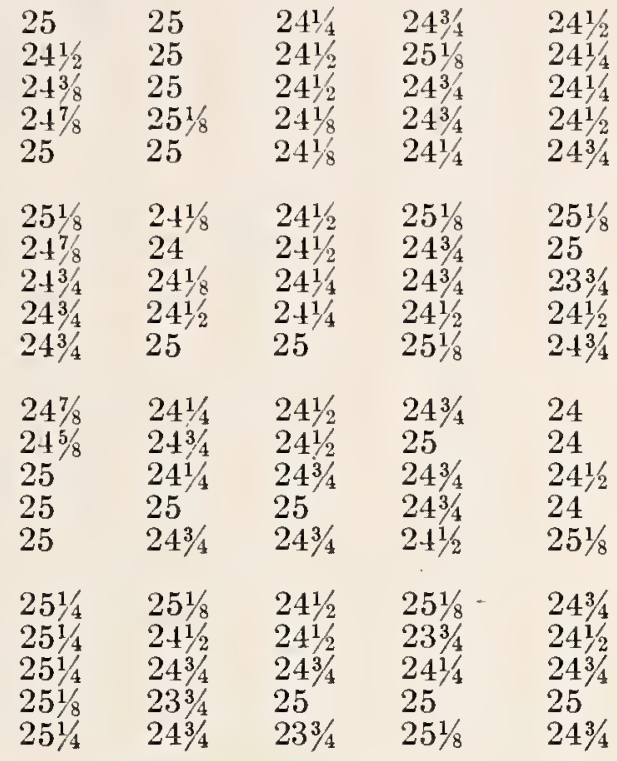

Wetght of 100 loaves: $2,467 \mathrm{oz}$

A verage net weight per loaf: $24.67 \mathrm{oz}$.

\section{TABLE D}

Weights in ounces of 100 loaves selected at random from packaging room. Scaling weight $281 / 2$ oz label weight $24 \mathrm{oz}$., baking time 27 minutes in tunnel oven. Loaves weighed after wrapping.

$\begin{array}{lllll}25 & 241 / 2 & 245 / 8 & 247 / 8 & 241 / 2 \\ 241 / 8 & 241 / 2 & 251 / 2 & 241 / 2 & 241 / 2 \\ 241 / 2 & 233 / 4 & 241 / 2 & 251 / 8 & 243 / 4 \\ 25 & 241 / 8 & 25 & 241 / 8 & 24 \\ 243 / 8 & 241 / 2 & 25 & 25 & 25\end{array}$

$\begin{array}{lllll}241 / 2 & 24 & 251 / 4 & 25 & 25 \\ 243 / 8 & 241 / 8 & 251 / 2 & 24 & 24 \\ 241 / 8 & 241 / 8 & 241 / 4 & 25 & 241 / 2 \\ 241 / 2 & 241 / 8 & 251 / 4 & 24 & 241 / 2 \\ 237 / 8 & 25 & 25 & 241 / 8 & 24 \\ & & & & \\ 25 & 241 / 2 & 243 / 4 & 243 / 8 & 25 \\ 241 / 2 & 25 & 241 / 2 & 241 / 8 & 24 \frac{1}{2} \\ 241 / 8 & 241 / 8 & 243 / 4 & 237 / 8 & 25 \\ 241 / 2 & 243 / 8 & 241 / 4 & 247 / 8 & 25 \\ 241 / 8 & 25 & 24 & 241 / 2 & 23 \frac{3}{4}\end{array}$

$\begin{array}{lllll}25 & 241 / 8 & 243 / 4 & 241 / 2 & 24 \\ 251 / 8 & 25 & 241 / 2 & 241 / 2 & 25 \\ 243 / 8 & 25 & 25 & 25 & 241 / 2 \\ 25 & 24 & 243 / 4 & 241 / 2 & 243 / 4 \\ 241 / 2 & 25 & 241 / 2 & 241 / 2 & 243 / 4\end{array}$

Welght of 100 loaves: $245658 \mathrm{oz}$.

Average net weight per loaf: $24 \%$ oz. 
and they contribute to the necessity for broader weight tolerances than the baker cares to have. $\mathrm{He}$ determines in advance through test baking what these "bakeout losses" will amount to and endearors to allow for them in setting the scaling weights at the divider. Such losses may range from $1 \frac{1}{2}$ ounces to $2 \frac{1}{2}$ ounces or more per onepound loaf, depending upon the basic formula, equipment used, and the inherent rariables in baking the loaf. Cooling losses may range from 0.4 ounce to 1 ounce, depending upon types of doughs and cooling conditions.

A recent study made by an independent baker's service laboratory recorded the results of variations in absorption and variations in baking time as they wonld affect the crumb softness and moisture loss of the bread.

The first series investigated consisted of six control doughs baked in a $475^{\circ}$ oven with variations in baking time ranging from 13 to 25 minutes. Observations were made periodically to determine the weight loss of the doughs at each variable and the relative crumb compressibility was determined on the resultant bread.

The results of this test are shown in table 1 .

The second series investigated was an absorption series with variations in total dough absorption varying from $71 / 2$ percent above normal to 4 percent below the normal requirements. Weight losses during the baking process and the final moisture contents of the bread were recorded as indicated in table 2 .

The third series investigated a series of doughs baked at $425^{\circ}$ having raried absorptions. 'The weight losses during baking and after cooling were recorded. Table 3 records the results of this series of tests.

A study of weight deriation and comparisons using two different piston designs was investigated in still another study. 'The weight variables and inconsistencies are recorded in table 4.

\section{Conclusions}

The bakeout losses and cooling losses additively were found to vary directly with baking time at a given oven temperature. It was noted that this weight loss increased at the rate of one-half percent per minute of extended baking time at $475^{\circ} \mathrm{F}$.

The bread moistne was observed as rarying directly with dough absorption within the limits of 58.5 percent and 70 percent absorption and under set baking conditions. 'The bread baked at $475^{\circ}$ for 21 minutes lost an averige of 1.7 percent nore weight than bread biked at $425^{\circ}$ for 23 minutes.

It should be noted that these data were taken under the precise control of laboratory facilities. The controls in actual commercial bakery production would vary considerably from that of the laboratory and it can be concluded that these variables and their effect on the final bread weight could be much greater than those recorded by these tables.

In eacl of the first four tables shown the baker found it necessary to play it safe by scaling his weights with enough overweight to insure a safe margin in the overall average weights of his product. To do this, he gave as much as 0.9 onnce of his product away with each loaf. In dollars and cents per 1,000 loaves sold, it would mean that his loss would be $\$ 10.40$ if calculated at a wholesale selling 
TARLE 1. Variations in baking lime.

Effoct on weight loss and crumb softness.

Absosption 62.5 pereent-baking temperature $475^{\circ} \mathrm{F}$.

Percentage weight loss in oven and in cooling.

$\begin{array}{crrrrrc}\begin{array}{c}\text { Falingtime } \\ \text { minutes }\end{array} & \text { In oren } & 15 \text { min. } & \text { Somin. } & 45 \text { min. } & 60 \text { min. } & \begin{array}{c}\text { Average com- } \\ \text { pressibility }\end{array} \\ 13 & 6.9 & 7.8 & 8.0 & 8.5 & 8.7 & 155 \\ 15 & 7.3 & 8.5 & 8.7 & 9.3 & 9.7 & 154 \\ 17 & 8.5 & 9.4 & 9.7 & 10.1 & 10.4 & 139 \\ 19 & 10.0 & 10.8 & 11.1 & 11.5 & 11.8 & 137 \\ 21 & 11.2 & 12.0 & 12.2 & 12.5 & 12.7 & 325 \\ 23 & 11.6 & 12.5 & 13.3 & 13.4 & 13.5 & 126 \\ 25 & 12.9 & & & & 15.3 & 124\end{array}$

TABLE 2. Variations in absorption.

Effect on weight loss and moisture content.

Bake time-21 minutes at $475^{\circ} \mathrm{F}$.

$\begin{array}{ccc}\begin{array}{c}\text { Absorption } \\ (\%)\end{array} & \begin{array}{c}\text { Pake out loss } \\ (\%)\end{array} & \begin{array}{c}\text { Total loss after } 1 \mathrm{hr} . \\ \text { cooling }(\%)\end{array} \\ 70.0 & 12.3 & 14.6 \\ 66.5 & 12.0 & 14.5 \\ 62.5 & 11.7 & 13.8 \\ 60.0 & 11.7 & 13.7 \\ 58.5 & 11.6 & 13.6\end{array}$

TABLE 3. Effect of variations in dough absorption on moisture contcnt of bread.

Bake time 23 minutes-bake temperature $425^{\circ} \mathrm{T}$.

$\begin{array}{ccc}\begin{array}{c}\text { Pecent } \\ \text { absorption }\end{array} & \begin{array}{c}\text { Percentbate } \\ \text { outloss }\end{array} & \begin{array}{c}\text { Total weight loss } \\ \text { after Ihr.cooling }\end{array} \\ 70 & 8.6 & 11.5 \\ 64 & 8.3 & 10.8 \\ 58 & 7.7 & 9.7\end{array}$

TABLE 4. Distribution of individual deviations in weight on 20-ounce brcad.

\section{Deriations}

Less than $\pm 0.25 \mathrm{oz}$

\pm 0.25 to $\pm 0.45 \mathrm{oz}$

\pm 0.45 to $\pm 0.65 \mathrm{oz}$

\pm 0.65 to $\pm 0.85 \mathrm{oz}$

More than \pm 0.85 oz

$\begin{array}{cc}\begin{array}{c}\text { Conventional } \\ \text { pistons } \\ 1958\end{array} & \begin{array}{c}\text { Piercing rod } \\ \text { pistons } \\ 1958\end{array} \\ 27.3 \% & 30.6 \% \\ 25.8 \% & 22.6 \% \\ 9.1 \% & 22.6 \% \\ 13.6 \% & 19.4 \% \\ 24.2 \% & 4.8 \%\end{array}$

price of $181 / 2$ cents per pornd loaf. At a manufacturing rate of 7.000 loaves per hour, this amounts to a substantial loss of $\$ 72.83$ per hour. Thus, the baker certainly is interested in any reasonable means for improving his control over the variable factors of baking and narrowing down the tolerance latitudes of weight control of his products. However, until more is known of the basic variables of his main ingredient, flour, and the practical control of them, he will have to set broad limits of tolerances for his finished weight.

\section{DISCUSSION ON FOREGOING PAPER}

Mr. Rebuffo: In the surveys described, what type of bread was used?

Mr. Schier: This was the common and popular white bread. 
Mr. MEEk: With respect to your statement about bread tolerances, Mr. Schieb, I would like to call your attention to a discovery made in Indiana a year or so ago, where a large bakery was baking certain loaves for interstate shipment and others for intrastate shipment. The interstate shipment was found to comply with the Federal Food and Drug tolerance requirements, and the ones baked for the State of Indiana met with our State requirements, which permit 1 ounce per pound as a tolerance. We brought this to the attention of the Indiana Bakers Association and they backed a bill in the Indiana State Legislature which was enacted. It abolished the tolerances provided in the Indiana law and adopted verbatim the variations provided under the Federal as well as our State Food and Drug and Cosmetic Act. Do you not believe that this is a better approach to this variation or tolerance problem you mentioned than to have stated specific tolerances in the law, such as we formerly had in Indiana?

Mr. Scrimen: Yes, this meets the broader conditions of baking manufacturers. In other words, if we set our tolerances too close and to too-defined limits in our products, we penalize more than likely the smaller operator rather than the larger operator, and I believe that the requirements should be to meet the flexibility reasonably within the manufacturing capabilities of our entire industry.

Mr. MeEk: We found in discussing this problem with the Indiana Bakers Association that they were very desirous of giving correct weight. The larger bakers were doing that. We found they wanted also to comply with our law by baking loaves a little lighter. The approach now will give us the same protection for our citizens in Indiana as was heretofore given to people who bought this product out of the State.

Mrr. JEssen: I should like to preface my question with a brief explanation. Under the Model Law and Model Package Regulation adopted by this Conference, packages of any commodity-food, drugs, cosmetics, and anything else-are required to average in net content the quantity stated on the outside of the package. The average quantity must at least equal the stated quantity. Then variations are permitted both above and below, except that no unreasonable shortages are permitted, even though these are balanced by overages in the other packages in the same lot.

The question I should like to ask is this: Would the American Bakers Association favol this type of permitted variation for loaves of bread?

Mr. Scmeb: Yes, in my opinion, I think we would. We would, of course, want to define what the "reasonable" is. Definitions are in order. I think it is an aid to the enforcing officers as well as to the bakers or producers, and these definitions, of course, should be realistic.

Mr. M I J Jomnson: Were these tests run on the old dough process or on the continuous-mixing process?

Mr. Scmirb: These tests were run on the conventional dough process, which is the sponge and dough method. Mr. Johnson is referring to a newer system that is coming into the industry, called continuous mixing. This is quite an automated system. Its use is rather spotty throughout the country. One trade name for this 
kind of bread is called "batter-whip," and the accuracies, incidentally, of weight control here are excellent.

Mir. Jonxsox: I find that, with the newer process, the bread will hold the moisture longer.

Mr. Scrine: This is true, inasmuch as with the batter-whip method or continuous-mix method, the shelf life of a loaf of bread, it is said, can be extended from $2+$ to 48 hours. The retention of the moisture is a part of that solution.

Mr. R.munNo: I recently found that one of our large bakeries was exercising no quantity control whatsoever at the end of the line. Should not a large baker have control at the end of the line to determine whether the bread is correct?

Mr. Scunes: Not knowing the particular baker to whom you refer, I would say he probably did have a control whereby random pieces were taken from the package line back to the laboratory within the plant or into the production manager's office, and there you would have seen scales and rolume devices for measuring volume, because to the baker the rolume of the bread is important too.

Many good bakery operators have installed in the packaging line an alarm system comprised simply of electronic eyes which will set off an alarm when the volume of the loaf is too small, which might indicate underweight too, but not necessarily be so. Or when the volume is too great, it would also indicate the oversized loaf. Also frequently used on the same line is a scale in which the package operator rould spot check the package at that point. More often it is done by simply removing the loaf from the line at random and checking it at the laboratory or the office.

\section{QUANTITY CONTROL AT PROCTER \& GAMBLE}

\section{By J. H. Chaloud, Associate Director, Product Development Division, The Procter \& Gamble Company, Cincinnati, Ohio}

Wre welcome this opportunity to talk to your Conference on the subject of "Quantity Control at Procter \& Gamble." This desire to describe our quantity control procedures is based on a recognition of our mutual interest, which is to insure that the consumer obtains the full measure of service when she buys our product. In a consumer-oriented company such as Procter \& Gamble, we recognize the ultimate purchaser and user of our product is our true "boss" and to serve her well is the basic creed of our company.

In its 124 years, Procter \& Gamble has been consistently building its business on the development and sale of service products. IVe are convinced that housewives continue to buy our products because of the service they perform for her. To build that service into a product, we must do three things. First, we must develop a formulation which will perform the intended service. Second, we must maintain precise chemical quality control to maintain this formulation. And third, we must be sure that she obtains within the package the correct amount of product so that she will obtain the full amount of service for which she has purchased this product.

Our interest in supplying to the consumer the proper weight of products goes beyond what we consider the legal responsibility of having the average of a lot, shipment, or delivery at the stated net 
weight or above. We recognize the National Bureau of Standards Handbook 67 on Checking Prepackaged Commodities has this average concept as its basic philosophy. As I said, however, we feel our responsibilities go beyond this, for we know that a housewife uses many of our products on a volume basis; for example, a cup and a half of detergent to do the laundry, or a cup of pancake mix for making her Sunday breakfast. If our product density is off, then her performance will be off. If our weights within the package are off, then she will not obtain the normal number of uses or the optimum performance, and if this happens often she will quit buying the product. The respect the honsewife's ability to discern such differences.

We have a written policy within our company which is quoted directly from the Manufacturing Standards which are given to every plant as its basic standard and instruction for controlling the fill of a package.

It is the company's policy to fill every package so that the net weight, rolume, or count equals the target weight, rolume, or count specified in Packing Standards. Unreasonable shortage in any individual package is not acceptable and overages and shortages camnot be considered compensatory.

Is you can see, it is our purpose to attempt to fill erery package to the target packing weight. It shonld be explained here that we do not consider the packing target weight to be the net weight; in fact, in most cases it is not. Is seen later in the development of our packing control procedure. onr packing targets are set so that we can say with complete conviction our packing target weights are always at or above the net weight.

Even with strict Manufacturing Standards and the best of intentions to fill each package at the target weight, variation nevertheless does exist and some variation will always exist. It is a fact of life that no repetitive operation can be done exactly the same way. For example, we know the cardboard used in detergent cartons will vary as much as $1+$ percent in weight. Even with careful control of the gluing machines, we linow the weight of glue required to seal cartons will normally vary abont 8 percent. The making and packing of our products are no exception to this problem of rariation.

To illustrate this point I would like to mention certain aspects of making and packing detergent powders which are directly related to the problem of weight control. Even though consumer packages are small, the starting ingredients are received in very large quantities. Such commodities as sodium phosphates, fatty alcohols, and alkyl benzenes, all of which are starting materials for the presentday detergents, are received in hopper cars and tank cars from several suppliers in 100,000-pound lots. There are slight chemical variations and also some density variations in the materials we receive. Additional density valiations result from the process of making a spray-dried product such as the present-day detergents.

Even though we know of the variations in raw materials and in the spray-drving process, it becomes our job to control the product density as close as possible to a predetermined fixed value that will give the proper packed weights in the package with a minimum of outage or free space.

We have obtained from equipment manufacturers the best instruments and equipment available for control of product density, and 
have found it necessary to develop other tools of our own, such at a continuous density meter and recorder and specially devised product blenders that will achiere the optimum flow of constant density product to the packing room. In addition to the automatic density records, many checks are made of the density of material as it flows to the packing room. The product bins into which it goes are segregated with regard to the actual density readings taken, so that we would be able with proper selection to maintain the most uniform density of product going to the filling machine.

The final control of product weight must be achieved in the packing room. Thatever density variations have occurred in our product through raw materials, process, and filling machines must be recognized here and corrected. The girls who operate the packing line are responsible for achieving the basic aim of the company's policy in attempting to get the packing target weight into each box. Quite literally, hundreds of weighings are made each day from each packing line, and corrective action is taken based on these weights.

I believe the best way to demonstrate the practical means of weight control is to develop a histogram. As the packing girl continues to make many successive weighings, the actual weights of the product above and below the packing target can be plotted in terms of units of $1 / 16$ th of an ounce as is done with this histogram (fig. 1). As thousands of samples are weighed, our histogram continues to grow; the top of each of the bars begins to form the typical bellshaped curve or what statisticians refer to as the normal distribution curve. Every product and every package size will result in just such a distribution around a packing target. We have never seen any product in our industry or others in which there is not this same normal distribution form, although the exact shape of the curve may rary. We must first find out through experience with each product and each type of filling machine what is the shape of this curve. Knowing this, we can then set the packing target weight at some ralue above the marked weight. If the curve is broad and flat, we must have a large spread between the marked and packed weights. If the curve is narrow and steep, the spread can be considerably less.

As an example, you can see from a typical normal distribution curve for a granular detergent product, we would assign a packing target at a point above the marked weight so that the number of individual packages that would be made below the marked weight is kept to a reasonable minimum (fig. 2). We would like to emphasize from just this curve that the number of packages made below the marked weight is small when compared to the number of packages that are above the marked weight. As we gain more experience and obtain better control of product and product packaging, the shape of the normal distribution curve might improve. In some cases we have been able to improve our operation so that these curves become more steep and the concentration of the product weights is closer to the packing target.

Returning to the packing room, where most of the machines measure the fill by volume, the operators in charge of the line do have certain machine controls designed to keep this variation to a minimum. In addition, it is their responsibility to be certain the average of the packing weight does indeed fall on the packing target. We use an 


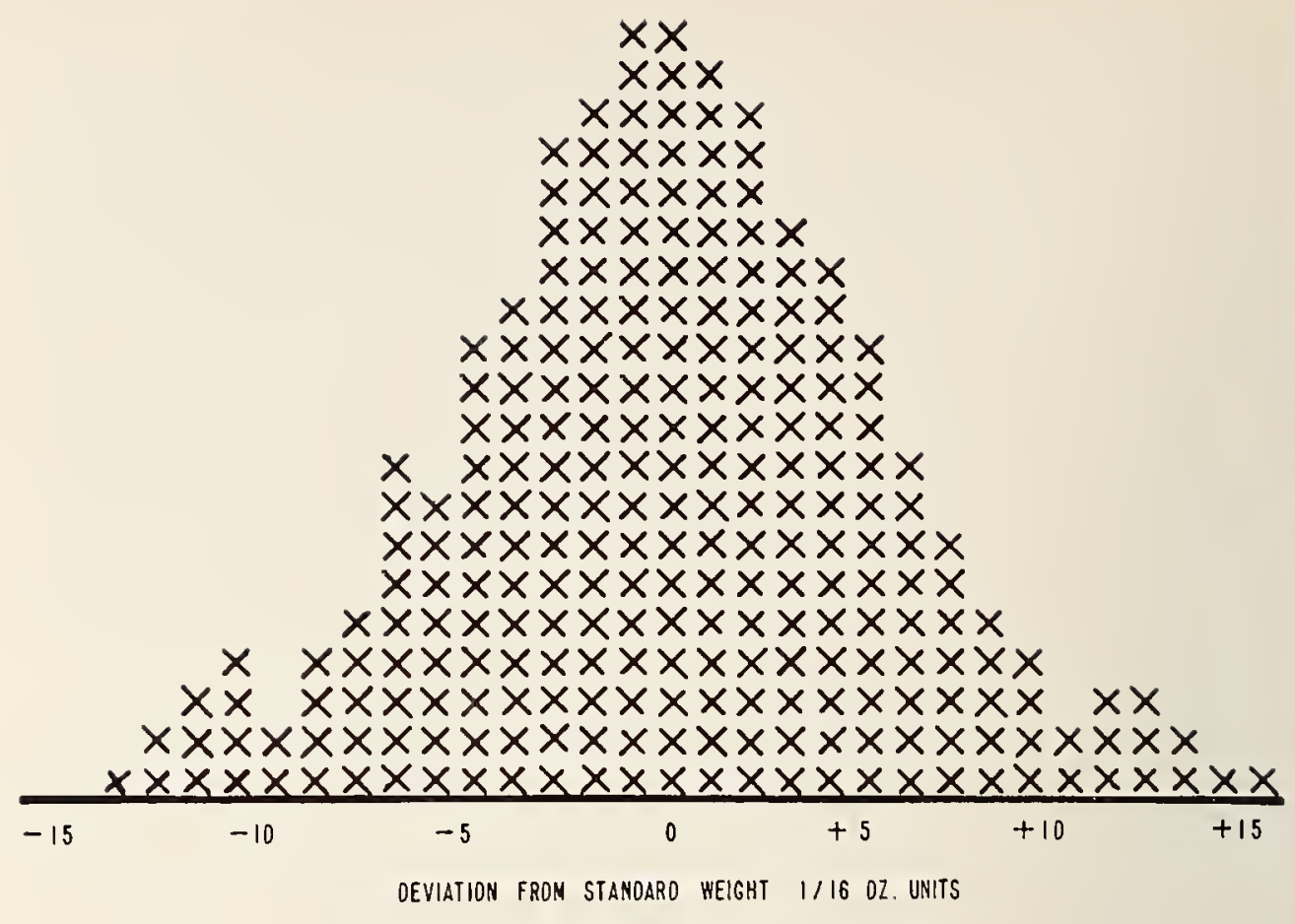

Figure 1.

"X-bar" or range control chart which serves to tell the operator when to make a correction and how much, and, even more importantly, its proper use will prevent mmecessary variations through overcontrol (fig. 3). As an operator takes her samples from the packing line, the weights are recorded on a graph in terms of the sum of three weighings. 'The sum of these three weighings is then plotted on the range chart, which has an upper and lower control limit placed on either side of the packing target weight. The placement of the range limits is established on the basis of the normal distribution curve which experience has shown that packing line and product will prodnce. Whenever an instance occurs in which the sum of the three weighings crosses either the upper or lower range line, then an immediate correction is made by the operator by turning the hand wheel on the filling machine head. If the sum of the three weighings falls between the packing target and the upper range line and a series of four successive groups plot in this same area, the operator is required to make another slight adjustment to the filling head so that she would bring the arerage of her weighings closer to the packing target. The range chart is not a mathematical device to compensate overages with shortages or vice versa, but rather the range chart is a procedmre for bringing the actual packing weights closer to the packing target.

There may be some tendency to believe the variation we find is due to our desire to operate volmmetric fillers at high speed. Quite obivously, we are eager to use such high speed equipment, for its cost per package is low. However, we have some products which are still being packed on slow, net weight fillers. We have the same information with regard to weight variation and range control chart data on a machime such as this, and we know from experience on dozens of machines of this type that our percent of varia- 


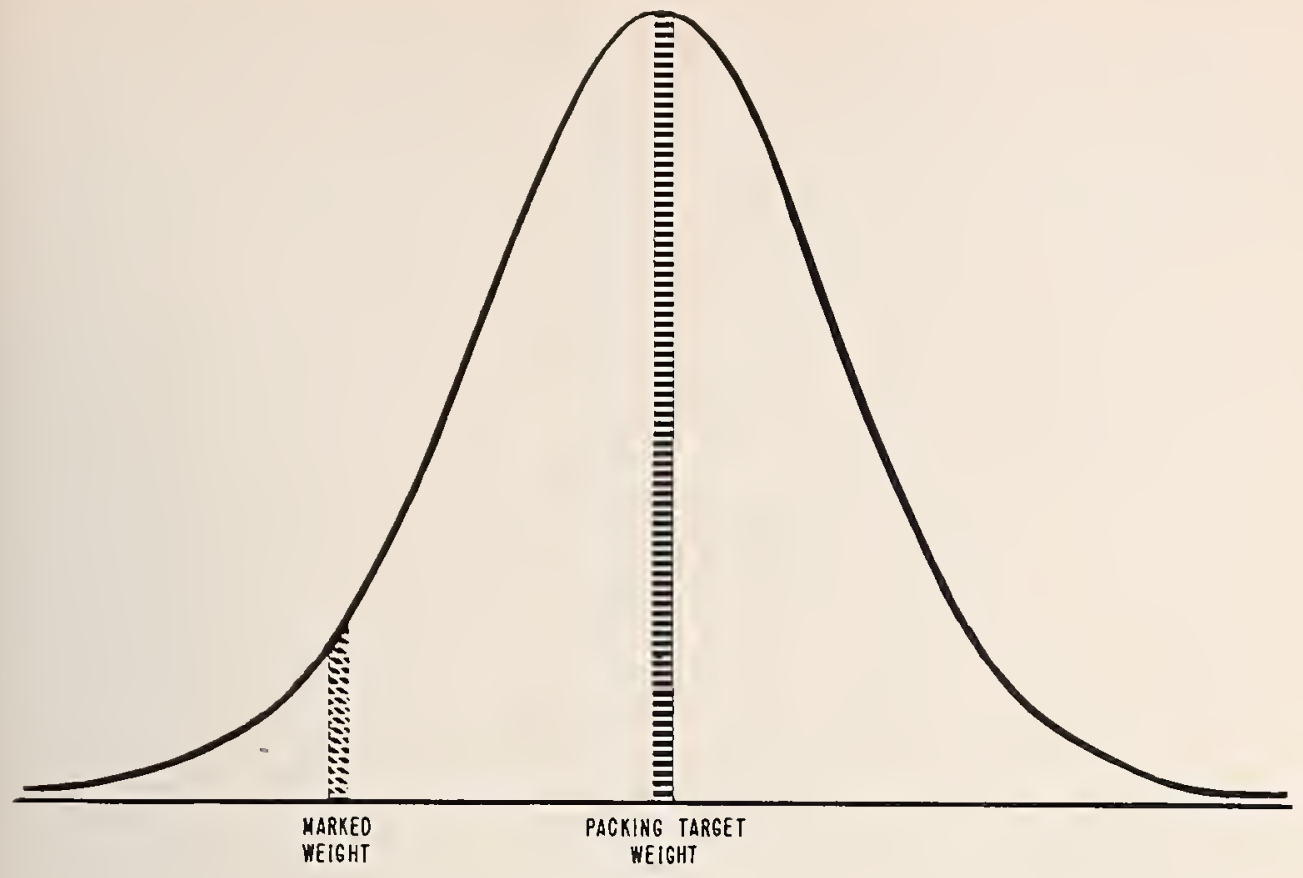

Frgure 2.

tion in weight is no lower than we obtain from a high speed volumetric filler.

In fact, we even have some operations in which our weighings of product are made manually for each individual package. Quite obviously one might feel this should be the most accurate of all, but packing room data prove that this is not true. Human and fatigue factors lead to error, and when all of the data are gathered we find that this is no more accurate in terms of percent of variation than the volumetric filler. We are convinced that, when all things are considered, the most efficient machines for each size will lead to the best control.

Our quantity control in Procter \& Gamble does not stop at this point, for we must be certain the actual packing-room data are accurate. This is done by the quality control manager in each plant being responsible for taking frequent but random samples of production as it goes into the warehouse. These samples are carefully weighed for net weight and serve as the weight record samples for the plant and its production. Such samples, we believe, are free of bias and give an accurate picture of the weight control we achieve.

A final step in being certain the customer attains her full measure of product is that each month we go out to a number of stores within each plant area and buy hundreds of our products and product sizes, so that we can then examine them and weigh them. Our experience is that the variation increases somewhat through the exposure of product to different environmental conditions, but we have data to show that, whatever the circumstances might be, the average weight of the product purchased in the trade still falls at or above the marked weight that appears on the package.

An audit of our control is made by having an independent purchasing organization buy our products throughout the Nation every 


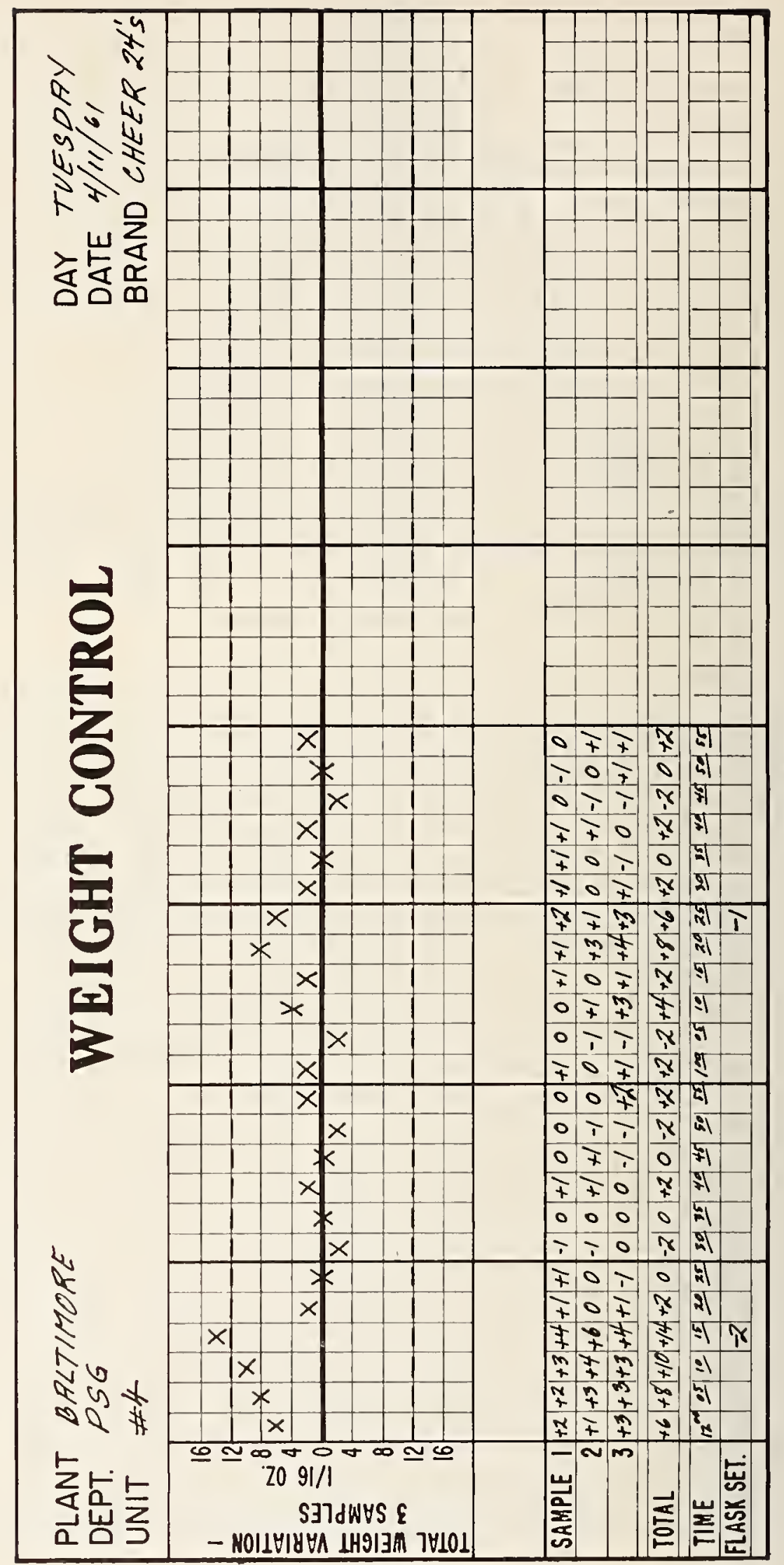


6 months. All of these samples are returned to Cincinnati and examined carefully for quality as well as quantity control. Once more the pattern is as before in that we find the rariation has increased just slightly but that the arerage of the reights has held remarkably constant, still being always at or above the marked weight.

TWe want to reduce weight variation; in order to do so, we maintain a continuing program of development work on packing equipment. For example, we have a test unit now under study in which a gamma-ray density detector is used to sense the powder density prior to going into the filling head of a packing machine and automatically correcting the filling machine head for these variations in density. Another device is designed to sense the weight of every package and compute the average or trend and feed back to the filling machine a control signal to correct for whatever error the automatic sensing device has found. Obviously such devices are new and experimental, and they will have to prove their effectiveness and ralue before we could justify using them broadly.

No discussion on weight-control procedures would be complete without mentioning our method of standardizing packing room weights and calibration of packing room scales. The responsibility for this function rests with our Cincinnati Standards Laboratory, which is the central standardizing agency of Procter \& Gamble. This laboratory is responsible for standardizing, certifying, and checking the instruments and apparatus used to measure the fundamental physical and chemical factors involved in our business. Just as an item of interest, this laboratory is responsible for the standardization and maintenance procedures of 2,775 scales and balances throughout the company.

We believe the laboratory is well equipped for this job. It has four precision balances, ranging from a micro balance with a total capacity of 1 gram to a bullion balance with a capacity of 66 pounds. As a primary mass standard, it has a set of Class "M" precision laboratory weights, certified by the National Bureau of Standards, ranging from 0.001 gram to 100 grams. As a primary avoirdupois standard, it has a set of Class "S-1" weights, from 0.1 ounce to 50 pounds, also certified by the Bureau. Our Standards Laboratory, among its other activities, standardizes, adjusts, seals, and certifies the rarious classes and sets of secondary reference weights used in the different plants and laboratories of the company.

Each plant of the company in the United States has two different sets of secondary reference weights. Each plant laboratory has a set of Class "S-1" metric weights, certified at the time of purchase by the Bureau. These reights are checked and recertified every 3 years by our Standards Laboratory against the primary Class "M" weights. Each plant also has a set of stainless steel Class "C" weights, ranging from $1 / 32$ ounce to 25 or 50 pounds. These are standardized, sealed, and certified by the Standards Laboratory against their primary Class "S-1" weights. Each plant also has a small set of stainless steel "Sealer's Weights," Class "C." These sets of secondary reference weights are used to check and adjust the various weights, including tares, counterweights, and check weights, used at the many scales throughout the plant. 
Each plant has an Instrument and Scale Shop equipped and staffed to maintain, repair, and adjust the instruments, gages, and scales necessary to our operations. Each shop has a 25-pound capacity shadowgraph scale, accurate to $1 / 40$ ounce, for testing and adjusting the packing room weights.

Each automatic filling and packing machine has a scale, generally of 5-pound capacity, used only for checkweighing the packages of finished product made on that line. These scales are inspected and tested on a daily, weekly, and monthly schedule, the details of which were developed with the assistance of Mr. Jensen and Mr. Wollin of the National Bureau of Standards. In addition, the scales are maintained in strict accordance to the specifications and tolerances of Handbook 44. The exact details of the daily, weekly, and monthly scale checking and testing are included in the appendix titled "Scale Inspection and Test."

In summary, quantity control at Procter \& Gamble has been, is, and will continue to be a matter of continuous responsible concern. We recognize that variation in our product weights does exist, but we take the position that it is our responsibility to hold this variation at the lowest possible level. To be sure this responsibility is always met, each month some 900,000 weighings are made in the packing rooms for filling machine control, an additional 31,000 samples are taken randomly from cases in the warehouse to have an independent quality check of the accuracy of the packing room data, and finally some 3,600 packages are purchased from the retail trade and each one weighed and inspected carefully to be certain the housewife is receiving the full measure of service she has learned to expect from these products. It might be of interest to know this deliberate level of orerpack is equal to $3,000,000$ pounds of product each month, or the equivalent of 81 boxcars of extra product which, incidentally, is a long freight train load each month.

We consider your prepackaged commodity weights inspections as a further and final quality test of the proficiency of the packing operation. Incidentally, we are grateful to several States who have sent to our attention the results of all inspections, almost all of which found the products above the marked weight. Our company believes in working with all weights and measures regulatory groups as the surest way of obtaining our mutual ultimate aim of giving a full measure of service to the consumers.

\section{APPENDIX. SCALE INSPECTION AND TEST}

For seales used in production checkweighing and quality control. Equal-arm, over-and-under indicator types

\section{A. Daily inspection and tests.}

1. Clcan scale and weights.

Wipe off pans, pan supports, exposed mechanism, beam, poise, and weights. Remove all dust and dirt. If necessary, wash off pans and dry thoroughly. Do not get any water on knife edges, pivots, or beariugs.

2. Check zero balance.

a. Remove all weights from both pans. Set poises at zero. Stroke one pan sufliciently to cause indicator needle to swing to one side of zero mark at least half the scale length. Indicator should return to rest at zero mark. Repeat to other side by stroking opposite pan.

If indicator does not come to rest at the zero mark, turn the "zero adjust" 
screw as required. Then repeat the above tests. The scale is in proper adjustment only when the indicator stops at zero after being displaced. If scale cannot be so adjusted, do not use until it has been repaired.

b. If the tares or poises ale fistened in such a manner that they cannot be relloved or set to zero, place a test weight on the load pan exactly equal to the fixed mass. Displace the indicator and test for return to zero as above. If necessary, turn the zero-adjust screw as required.

It is essential that the test weight be exactly equal in mass to the fixed weight, without the use of any tare such as an empty carton. This loadzero balance is not as sensitive nor as reliable as the zero load test, and is to be aroided if possible.

\section{Dash-pot adjustment.}

With the scale in proper zero balance, depress one pan to the limit of its travel. Release the pan. The indicator' should make two complete oscillations past zero and then come to rest at zero in less than one second. If it comes to lest with fewer oscillations and/or takes longer than one second, the scale is overdamped and insensitive. If it oscillates back and forth more than twice, the scale is underdamped and unstable. Adjust the dash-pot screw as required.

Note: Sluggishness may be due to other factors than the dash pot. If releasing the dash-pot adjustment does not speed up the action, remove the scale from service for repair.

\section{B. Weekly inspection and tests.}

\section{General conditions.}

Check scale for cleanliness, level, freedom of moving parts, and absence of foreign objects on pans or mechanism. Check weights for cleanliness and signs of misuse. Clean if necessary.

2. Cheek zero balanee in same manner as daily test. Adjust if necessary.

3. Cheek dash-pot adjustment as in daily test.

4. Sensitivity test.

a. Remore all weights and tares from balance, and set poises to zero. Be sure scale is in proper zero balance.

Using only standardized test weights, place a $1 / 16^{-o u n c e}$ weight on the load pan. The indicator should more to the corresponding graduation, or equivalent position on the dial. Move the weight to the opposite pan. The indicator should more to the correct position on the opposite side of zero. Place another $1 / 16$-ounce weight on the load pan. The indicator must register zero. Remore both test weights.

Place a 2-pound test weight on each pan. The indicator must register zero. Add a $1 / 16$-ounce weight to the load pan. The indicator must move to the corresponding graduation, or equivalent position, on the dial. Add a $1 / 16^{-o u n c e}$ weight to the opposite pan. The indicator must register zero. Remove the $1 / 16$-ounce weight from the load pan. The indicator should indicate the proper weight on the opposite side of the dial.

b. If the net weight tares or poises are fastened in such a manner that they cannot be removed or set to zero, place test weights on the load pan until the indicator reads zero. The stated weight of the net weight tare must equal the sum of the test weights within $+1 / 16$ ounce. Place $1 / 16^{-o u n c e}$ weights on each pan and test as given above.

If the dial graduation units are greater than $1 / 16$ ounce, the sensitivity test weight should be equal to one such unit.

If a scale does not meet the requirements of this sensitivity test, it must be removed from the job for a complete overhaul and readjustment. Sensitivity cannot be restored on the job.

If an incorrect tare is found, it must be adjusted before further use.

\section{Check net weight tare.}

If the net weight tare or counterpoise is out of the above tolerances, it must store it to the weight pan. Place test weights on the load pan until the indicator reads zero. The stated weight of the tare must equal the sum of the test weights within $\pm 1 / 16$ ounce.

If the net weight tare or counterpoise is out of the above tolerances, it must be adjusted before further use. 
1. Check zero balance in same manmer as daily test. Adjust if necessary.

2. Check dash-pot adjustment as in daily test.

3. Sensitivity test. Same as for weekly test.

4. Ratio test, increasing load.

a. With scale in correct zero balance, place the proper counterweights and poises for the filling target weight in place. Do not use or include any tare equivalent to the empty package. Place standardized test weights on the load pan until the indicator reads zero.

The total of the test weights must equal the target reight within the Ratio Test Tolerance listed in table 1 , and should equal it exactly.

b. Remove the test weights, but not the target tare weight. Bring the scale zero balance by means of any conrenient mass, sucli as a filled package of the correct net or gross weight. A tare equiralent to the empty package may be used in this test.

Place all of the ounce and fractional ounce weights, totalling one pound, on the load pan. Place a 1-pound weiglit on the opposite pan. Note the indicator reading. Place a 2 -pound weight on each pan. Note the indicator reading. In both cases, the indicator must read zero, within the Ratio Test Tolerances listed in table 1.

5. Ratio tcst, decreasing load.

With all the weights used in the previous test in place, bring the scale to zero balance, if necessary, by adding any convenient mass as necessary.

Remove the 2 -pound weights from both pans. Note the indicator reading. Remove the 1-pound weight from the weight pan and transfer the 8-ounce weight from the load pan to the weight pan. Note the indicator reading. Remove the 8-ounce weight, and transfer the 4-ounce weight from the load pan to the weight pan. Note the indicator reading. Remove all the check weights and note the indicator reading.

In all the above tests, the indicator must read zero within twicc the Ratio Test Tolerances listed in table 1 . A good scale, however, will be within half the tolerance on the increasing load test, and within the tolerance on the decreasing load test.

If any scale is found in either of the Ratio Tests that equals or exceeds the allowable tolerances, it must be remored from the job for orerhaul and adjustment.

If any incorrect tare or target counterpoise weights are found, they must be corrected before further use.

\section{Shift tcst.}

a. Remove all weights from both pans. Set all poises at zero. Place a standardized test weight, or weights, equal to 50 percent \pm 10 percent of the rated capacity of the scale at the center of the weight pan. Stack multiple weights so that the load is centered on the pan.

Place an equal standardized weight on the center of the load pan. Note the indicator reading. Successively move the weight on the load pan to not less than four equidistant points halfway between the center and the edge of the load pan. Note the indicator reading at each position. Note also any indications of sluggishness or decreased sensitivity.

Re-center the weight pan in the same manner. Note the indicator reading at each position.

b. If the tares or poises are fastened in such a manner that they cannot be readily removed or set to zero, the Shift Test may have to be limited to the load pan. The test weight should be approximately half the scale capacity.

In all positions, on either pan, the indicator must read zero within the Ratio Test Tolerances listed in table 1. In a good scale, any error will not exceed one-half the tolerance. Any scale with an error greater than one-half, but less than the whole tolerance should be repaired at the first opportunity. Any scale in which the error at any position is equal to or greater than the tolerance must be remored from service for repair. 


\section{Indicator test.}

With the scale in zero halance, place a test weight on the load pan equal to half the nurled capacity of the indieator scale. Note the indiactor reading. Transfer the weight to the weight pan and note the indicator reading.

Repeat the test on both paus, using a weight equal to the full marked capacity of the indicator scale.

In both tests, the indicator must agree with the test weight within the Indicator Tolerances listed in table 1.

\section{S. Bcam test.}

This test is made only on scales where the beam and poise reading is used in detelmining the mass on the load pan.

Place a test weight on the load pau equal to half the marked capacity of the beam. More the poise to bring the indicator to zero. Note the beam reading. lepeat the test at the full marked capacity of the beam.

In both tests, the beam reading must equal the test weights within the Weighbeam Tolerances listed in table 1.

9. Tet ueight tares or counterpoises. Check as for Weekly Test. 10. Recheck sero balanee.

\section{TARLE 1. Basic maintenance tolerances for checkweigh scales}

Known test load

pounds

up to 1

2 and 3

4 to 7 , inclusive

8 to 14 , inclusive.

15 to 23 , inclusive.

24 to 29 , inclusive.

$\begin{array}{cc}\begin{array}{c}\text { Ratio test } \\ \text { tolerance }\end{array} & \begin{array}{c}\text { Weighbeam and } \\ \text { indicator tolerances }\end{array} \\ \text { ounce } & \text { ounce } \\ 1 / 16 & 1 / 16 \\ 1 / 16 & 1 / 8 \\ 1 / 8 & 3 / 16 \\ 1 / 4 & 3 / 8 \\ 5 / 16 & 1 / 2 \\ 3 / 8 & 1 / 2\end{array}$

\section{DISCUSSION ON FOREgOING PAPER}

Mr. Cichowicz: You stated that you fill packages with a target package weight and that this target is above the net weight. Throughout your whole talk you emphasized the fact that only a small amount of the finished product was found on the grocery shelres to equal the marked weight and the rest of them equaled over the marked weight. With the great volume of product that Procter and Gamble puts out, I am wondering why you are giving away all this commodity.

Mr. Chaloud: Let me say quite seriously that we feel that we must be sure that the consumer gets what we think is a reasonable performance in her product regardless of what kind of errors we may make in the packing room. To be sure that this happens, we have consistently (and this goes back really to the first Mr. Procter in 1837, who wrote on his invoices that these products were full measure), established a history of overpacking. If that is an answer to your question, we believe in overpacking.

Why do we not try to make a bit more profit by reducing this overpack? We know there are agencies that are going to be sure we do not get on the wrong side of the fence, and even if we were always well intentioned, but started to play it too close, we would get into trouble. In fact, we have been in trouble. We have, as the movie shows, some of our products below the marked weight. We do not deny it. Sometimes it will be found in the trade below the marked weight, because a sample that is found in a store comes from only several seconds on one filling machine. During that period of time the product could average below the marked weight, 
and this has been found on some inspections. The point we try to make is to keep this to a reasonable minimum, and to do this we must maintain an overpack on our product.

Mr. Crchowrcz: I still am not convinced that overpacking is a good idea for such a large-volume company.

Mr. Chaloud: The consumer pays for whatever any packer does, and our main purpose is to be sure that she gets the right kind of product. The real key is to do the best job you can. The key I tried to point out is that we work hard to improve the steepness of the distribution curve. That is the goal for anybody in the packing industry. It is not to make an arbitrary overpack.

These figures are not big in terms of percentage. We are not overpacking in terms of many ounces, but only fractions of ounces per box. It is our way to insure (and this we consider necessary and the only legally defensible position) that we will always have data to show we average at or above the marked weight. We do not see how we could operate otherwise.

Mr. TURReLr: I certainly want to comment very favorably on your presentation here today, but I an wondering just how long it has been since you were as particular as you are now.

Mr. Chalowd: My presentation is intended to describe our two aims-what we do in the packing room and what we do to be sure we know what we do in the packing room. What we do in the packing room is covered by the $\mathrm{X}$-bar range control data and the difference between packed and marked weights. This has been going on, as far as I know, since before I joined the company in 1946 . We have always made studies to determine the average of our package weights and the range of data we will get from our packing machines. We then make necessary adjustments to be sure that we average at or above the marked weight.

In more recent years we decided, as a result of the growth of interest in the weights and measures field, that our level of reasonable overpack probably was not enough. We had an inspection by the State of West Virginia and decided, as a result of data they supplied to us, that we were not as generous in the difference between the marked and packed weights as we could be. We felt we would gain by making a more general program of deliberate overpacking.

The second part of your question concerns our program of knowing what we do in the packing room through weights standardization and scale checking. This actually has just recently occurred and is still going on, by the way. Some of these weights are not yet in the plant's hands. We learned with the help of the National Bureau of Standards that we were quite derelict in our knowledge of precisely what our weights really were in the plants, since we did not have standard weights. We were not in possession of the Class $\mathrm{S}-1$ certified NBS weights. This is now going on. We operated with weights that we had purchased and thought were accurate, but they were not certified.

Mr. Howard: My investigation discloses that the indicated weights on the packages of soap are very much in order; however, I am concerned with the representation of the quantity where premiums are included in the package, and that is the reason for my particu- 
lar investigation. As the result of a TV advertising, we made a soip survey to determine whether a package containing a premium was so filled as to mislead the purchaser as to the quautity of contents. I am not speaking of any particular product. 'This item is a package marked 2 pounds $101 / 2$ ounces. 'The price is $\$ 1.09$, which is 39 cents a pound. With the packaged premium, the package was 36 percent empty. The premium took up 30 percent of the capacity of the carton, and this 30 percent would have permitted 20 ounces, or 47 percent, more product in the package. On the container of the premium was the legend: "Please accept, with the compliments of (name brand), the following (which is the premium inside each package) and know it is yours at no extra cost."

Surveys show that the price per pound of the subject product with the premium is over 75 percent higher price-per-pound than before the premium was included. I am wondering if it would not suit the purchaser to have the premium on the outside of the package, perhaps, with the package itself having the normal fill of product.

Mr. Chaloud: Our company was the last in the soap industry to go to premium packages. They are costly and a burden to manufacturing. The quality control of the premium itself becomes one of the most taxing jobs in the plant. But we find that consumers want it, because we were losing business to the people who were selling premiums.

In answer to your question, first it is obvious that, if we are going to put the premium inside the box, some space must be available for it; so in the design of the package for premium packaged products, space was set aside for it. We have only one product in the entire $P$ and $G$ line that has a regular premium, and for that we made oversized packages. They cannot be packed on any of our highspeed equipment. We have to operate at slow speeds. It is a more costly product because of the labor that goes into it.

Our Premium Duz product has gone to great pains to be certain that the copy on the box and the TV commercials do not convey the impression that the chinaware is free. To my knowledge, this position is not abused, for we feel that it would be wrong to convey the thought that the chinaware was a gift when, in fact, we and the consumers both know they are paying for it.

There are times when our regular products such as Tide or Cheer will contain a premium such as plastic juice cups. When this is done, these premiums are free, and it is so stated. The weight control procedures discussed in my talk are applied to the packages before the insertion of premiums of this type, and it is necessary for the product to meet the packing target weight just as if the premium were not there. In addition, the premiums must be so sized that they will not greatly affect the outage of the package after the removal of the premium, because we know the housewifo uses the product on a volume basis, and if the product were to be made more dense she would over-use the product but not get as many uses from the package, and this we know will lead to complaints from the consumer.

Mr. G. L. Jornson: You use the words "giant," "family size," and other qualifiers. Then you put the net contents statement on 
the package in a size so small the consumer must use a magnifying glass to find it.

Mr. Chaloud: I made a point of looking in the morning paper here in Washington where there were soap products being advertised with the distinctions for sizes being by these same words you are talking about. We have giant, and we have king size, but these are words that now have meaning to people other than you and me. To the consumer, these words convey a meaning of size relationship so that she knows a "giant size" will last her family for a certain length of time regardless of which product she buys. We believe, however, that her results may vary as a result of brand selection.

We believe sincerely that a housewife who wishes to should have the right to know what the net weight in a box is. We think tre have done this for her in all our soap products which have the weight marking on the top of the package or on the top back side. Both of these positions put it as close as practical to the price patch. You know on soap packages all the pricing is done on a white spot on the top of the package. Right now we are looking at and having our art department reconsider the design of every one of our boxes, so the price patch and the marked weight will be immediately adjacent.

If you do not mind my going one step beyond your question, I would like to speak openly to the group on a subject which several people have asked me about during the meeting. Some people have heard that soap products change their weight frequently, and there will be different weights of products in the same size of package on the shelf. Nothing could be further from the truth. Tide has been in business for 15 years. We have only changed the weight in the product once. That was 3 years ago, when we advanced the weight slightly.

Another product, Cheer, has never had its weight changed. Crisco started in 1911 packed in 1-poumd and 3-pound units. In 50 years of selling, it is still in 1-pound and 3-pound cans. We have never changed the weight.

The most serious thing we can do in our company is to consider a weight change of a product. It cannot be done by anyone other than the Executive Committee of the company.

Mr. Howard: My survey in 1952 showed that you could buy soap cheaper by the pound by buying the quantity in smaller packages than in giant packages.

Mr. Chaloud: We have a general policy. We consider a 20-ounce box as the regular or basic size package. Each increasing size box must have a slight reduction in cost or a slight increase in value when we sell it to the retailer. We do not deny that these differentials are very small. Going from the regular to the giant is about 2 to 4 percent better value to the retailer.

We do not produce the bigger boxes because we want to. Take the home laundry size which you saw in the film packed by manual procerlures; that is the most expensive Tide we have. That costs us more per pound than other sizes of Tide, yet we have to sell it for a little bit less on a per-pound basis than any other size. We have letters right now asking for Tide in 100-pound boxes. We hope we have to do no further; otherwise we will get into operations 
in which we are not skilled. We are skilled in packaging things fast on high-speed equipment. Tre do not like hand operations, and they cost us money. That is part of the reason that you will never find these bargains to be big.

Mr. F.um: First, I would like to compliment you and your company for what you people are trying to do to see that the customers are receiving in product what they are paying for. My question is this: Does your company have humidity controls in their hopper sections and filling rooms?

ILr. Cimuoud: Not as a general practice. There are a few products where unusual humidity or temperature conditions would be detrimental. They are very new and very recent, and we find that normal air conditioning is the right answer. The real key to this is to try to determine what will be the loss or gain in weight after packaging as a function of humidity, and this, of course, becomes very important to us. Some of the packages, you may know, are very moisture proof and have moisture proof barriers built into the box. Because we know there is usually a tendency for detergent products to gain weight in terms of moisture pickup, we are not worried about the marked weight violation. We are worried that the consumer might not get the product out of the box. If it gets too moist, it cakes. That is a real problem in the material we send overseas. The product that goes into the Latin American countries must have moistureproof barriers on the package. The very few hours that a product sits in a packing room will cause no gain or loss in weight.

Mr. J. H. Lwws: In order to evaluate the reasonableness of our requiring llet weight, it is quite evident from your report that your company spends a great deal of money on this quality control program. Have you determined what this control program costs the housewife in cost per unit-

Mr. Chaloud: No, quality control is a manufacturing expense. In other words, we do not charge it anywhere other than right in the cost of manufacture. Just a sheer "guesstimate" is that it is probably in the neighborhood of 0.1 cent per unit at the maximum. The reason for that is that we do not have a great deal of destructive sampling. If we went into destructive sampling, that would begin to run our costs up. We do pack out a lot of products in the course of a day, so the quality control procedures distributed across a large number of units is reasonably small.

Mr. IV. I. Thompson: You mentioned that there are some 935,000 samples taken each month, and I believe you mentioned that you gave away some 3 million pounds of your product. I wonder if you care to reveal what percentage 935,000 would be of the total number of packages that you produce in a month and what the percentage of weight would be on the weight production.

Mr. Chaloud: I cannot do that very precisely. I think the answer has to be that we are never in a position to say we do a complete statistical sample. This is not the key. The key, as I tried to convey it, is the feedback of information to the packing machine. We are not sampling ammunition, or anything like that, where you would have to know the precise character of every unit. 
Mr. J. P. Leonard: In your opening remarks you brought out the point that the cardboard has a variation and the consistency of the glue has a variation. What is the total weight variation you did find in these boxes?

Mr. Chaloud: A variation of 14 percent is encountered in the total weight of cartons, that is between the extremes. Carton board made by high-speed, continuous operation in a paper mill does not vary greatly between successive cartons, but may vary more from hour to hour. For this reason we keep feeding back new tares to the packing line scale, to be sure that our weight of powder put into the box is as close to the packing target as we know how to make it.

Mr. Leonard: Does a carton absorb moisture from the product?

Mr. Chaloud: Not very often. You have to go into a bit of chemistry. One of the major ingredients in all detergent products is a phosphate. This phosphate has a very great affinity for water and wants to hydrate. It will hydrate water array from the cardboard if any is available. If the board comes with the actual vapor pressure above 35 percent relative humidity, the detergent will tend to take any excess moisture away from the board. In most cases, however, this is not a problem.

\title{
FOURTH SESSION-AFTERNOON OF THURSDAY, JUNE 15,1961
}

\author{
(A. D. Rose, Vice Chairman, Presiding)
}

\section{REPORT OF THE COMMITTEE ON RESOLUTIONS}

Presented by Rarmond Reburro, Chairman, Assistant Director, Division of Plant Industry, Department of Agriculture, State of Nevada

Resolutions of appreciation were adopted as follows:

1. To Honorable Luther H. Hodges for his constructive contribution to the program of the 46th National Conference on Weights and Measures.

2. To the Institute of Weights and Measures Administration and to Mr. J. R. Roberts for his excellent address on the Training of the Weights and Measures Official in Great Britain.

3. To governing agencies for their cooperation in facilitating attendance at the Conference.

4. To business and industry for cooperating with the Conference, for attending and particinating in its actirities, and for hospitality extended.

5. To program speakers.

6. To the Director and staff of the National Bureau of Standards for assistance in planning and administering the program and other details of the meeting.

\section{IRESOLUTION FOH REPUBLICATION OF IIANDBOOK 26}

Whereas, there has been prepared by Ralph W. Smith of the Office of Weights and Measures, National Bureau of Standards, the manuscript of a revision to NBS Handbook 26, "Weights and Measures Administration"; and

Whereas, the original version of Handbook 26 has become a standard text in this field; and

Whereas, the Chairman of the 46 th National Conference on Weights and Measures has carefully read and studied the manuscript 
and has formally recommended both its contents and its publication: Therefore, be it

Resolved, 'That this 46th National Conference on Weights and Measures urge the publication of the Handbook by the National Bureau of Standards and authorize the printing on the title page of the legend "Recommended by the National Conference on Weights and Measures": and be it further

Resolved, That the principles set forth in the revision to Handbook 26 are recommended by the Conference to all weights and measures officials and legislative bodies of States, counties, and cities.

\section{RESOLUTIOY FOR TRADING IN GRAINS BY WEIGIIT}

Whereas, the National Conference on Weights and Measures has for many years urged the official adoption of the hundredweight unit as the basis for trading in grains; and

Whereas, studies have demonstrated that a weight-derived volumetric bushel unit in the grain trade cannot be justified technologically or economically and that there are no major legal institutional or psychological barriers to the transition to a strictly weight basis that cannot be overcome in an orderly manner; and

Whereas, the National Association of State Departments of Agriculture, having had this matter referred to it by the National Conference on IVeights and Measures, has pursued the proposal vigorously through an action committee under the chairmanship of D. N. McDowell, Director of Agriculture, State of Wisconsin: 'Therefore, be it

Resolved, That the National Conference on Weights and Measures respectfully request at this time that the National Association of State Departments of Agriculture propose to the U.S. Department of Agriculture that it establish a target date not later than July 1, 1962, for the conversion of their feed-grain, price-support-loan, and storage programs from the bushel basis to the hundredweight basis: and be it further

Resolved, That this Conference urge that each weights and meassures official pursue in his State action and education programs with interested and affected groups.

\section{CONSUMER PROTECTION}

Whereas, consumer protection and consumer education are constantly increasing in importance to the Nation's economic well being; and

Whereas, equitable comparisons and intelligent decisions by the consumer in the market place are growing more and more difficult; and

Whereas, the President of the United States has recognized the importance of consumer interests in the public announcement of his intention to appoint a consumer counsel in the office of the President: Therefore, be it

Resolved, That this the 46th National Conference on Weights and Measures, assembled in Washington, D.C., on the 15th of Jume, 1961, does officially commend the President on this decision and offer the full cooperation of this organization to the person appointed to that important post: and be it further 
Resolved, That a copy of this resolution be sent to the President and that additional copies be furnished the Nation's press.

\title{
LABELING AND ADVERTISING
}

Whereas, the labeling and advertising of quantities of commodities offered for sale is becoming less straightforward, more confusing, and increasingly deceptive; and

Whereas, plain and honest representation of quantity, whether it be in advertising, labeling, or in other form of communication, is of vital concern to all consumers and to weights and measures officials throughout the Nation: Therefore, be it

Pesolved, 'That the 46th National Conference on WVights and Measures does hereby respectfully urge that all manufacturers, packers, advertising agencies, and other's with interest carefully survey and study this area of their own operations, with the aim of seeing that all laws, regulations, and moral obligations are fully complied with: and be it further

Resolved, That this resolution be included in the minutes of this meeting and that it also be given the widest practicable distribution among those interested.

\author{
Rarand Rebuffo, Chairman \\ G. IV. BAY \\ J. T. DANiELL \\ IV. C. Hughes \\ IV. II. Jennings \\ J. F. MADDEN \\ N. P. Thllemin
}

(On motion of the Conference Chairman, seconded from the floor, the report of the Committee on Resolutions ras adopted by voice rote.)

\section{REPOR'T OF THE EXECUTIVE COMMITTEE}

Presented by R. E. Mwn, Chairman, Director, Division of Weights arid Measures, Board of Mealth, State of Indiana

The committee, fully aware that its actions can be only reflections of Conference consensis, appreciates the excellent reports, both written and oral, to its several inquiries and appreciates also the many constructive comments made during its open hearing on Tuesday.

The Executive Committee presents now, for consideration by the Conference, the following items:

\section{Organization and Procedure of the National Conference}

1. The following proposed amendments were presented formally to the $45 \mathrm{th}$ National Conference, in accordance with the procedure covering amendments. The Executive Committee now recommends final adoption of these amendments by this Conference.

(a) Section 3. Constituent Membership.-Amend the final paragraph of Section 3, Constitnent Membership, which now reads, "Members of all classes have the privilege of the floor at meetings of the Conference" to read:

Members of all classes have the privilege of the floor at all meetings of the Conference except executive sessions. Attendance at an executive session is 
limited to the active and advisory membership, members of hoth classes having the privilege of the floor.

(b) Section 6. Duties of Oflicers.-Imend the second paragraph of Section 6, Duties of Officers, by adding at the end of the present palragraph a sentence reading:

The Conference Chairman is authorized to order an executive session of the Conference at any time such a session is deemed ly him to he in the best interests of the Conference.

\section{DISCUSSION OF ITEM I}

Mr. Alikix: I do not understand the purpose of this amendment. From the viewpoint of an associate member, it looks like it may be some means to get us out of the room so there can be a discussion that we know nothing about. I am curious to know what is the purpose of what is anticipated in an executive session. I felt we were welcome here to at least get our voice in the affairs of the Conference, as I am getting mine in now. The recognize that we have no vote. What are the circumstances under which, in the future, we will not eren have a roice?

Mr. Mrek: Mr. Allen, there will be no circumstances under which you "will not even have a roice." It is not at the present contemplated and we do not presently know of a need for holding executive sessions. You are aware of the fact that practically all organizations do provide for executive sessions. We want to make that provision now. That was brought up and discussed last year. It is not contemplated that we will erer call an executive session to preclude discussion by the full membership of the National Conference, including associate members.

There can be occasions, however, when the active weights and measures officials will want to get together to discuss a problem peculiar to their own responsibilities as public oflicials. We feel that under Robert's Rules of Order we now have that authority. But, before the situation might arise, we think it would be well to provide in our organizational procedure the necessary language to prevent any possible misunderstanding, should the occasion arise.

Mr. Alrex: I appreciate what may be the intent of the present committee and the present officers, and so forth, but, in effect, you are writing rules for posterity, for the future of the organization. What your intent may be today may not be the intent of future committees or future executives.

Somebody in the future may say, "There it is in the bylaws; we have the privilege of doing this." As I get it, there is nothing in rour present rording that says that, for example, this session this afternoon, where you are going to vote on changes in Handbook 44, which are very vital to your associate members, could be an executive session. As I understand the wording here, there is nothing that says that some future committee, with perbaps not the same ideals and motives that you have, could not say, "We know these fellows don't want it, we are tired of hearing them talk, let's have an executive session and we will pass this and everything will be $\mathrm{O}$. K."

Would it not be wise to have some provision that says at least certain types of business that are of vital concern to your associate 
members, which perhaps is the main reason why the associate members attend your Conference, cannot be taken up in executive session?

Mr. Meek: As you know, Mr. Allen, this has been brought up before and laid over for adoption this year. I would like to make this remark. There is no ol ganiaztion stronger than the confidence that the members have in it. I think that, because of the reputation and history of the National Conference on Weights and Measures established over the last 56 years, you can rest assured there will be no action taken that will preclude full debate on the part of all concerned.

You talk about circumscribing and setting out certain limits. WVe cannot foresee all the limitations that you have in mind and that might develop later. 'This is simple language. It is in order. It is recognized by other organizations. TVe are not going beyond the bounds of propriety. We overlooked the matter at the time we drafted this organizational procedure. If I had thought of it, I would have certainly sugrested that we should provide for executive sessions.

(Item 1 was adopted by voice rote.)

2. The Director of the National Bureau of Standards, ex officio President of the National Conference, has suggested to the Executive Committee that it give serious consideration to the matter of its ex officio Secretary. The Organization and Procedure of the Conference now provides that the Chief, Office of Weights and Measures, of the Bureau is ex officio the Conference Secretary. As is known to the delegates, the Bureau is preparing for a move of its entire staff and program to the planned new Bureau facilities near Gaithersburg, Maryland. Involved in this move are many major and minor Bureau organizational changes. The Director thus feels that it would be most appropriate for the Conference to change its Organization and Procedure to provide simply that a senior and qualified weights and measures authority on the Bureau staff be designated by the Director to serve as the Conference Executive Secretary.

Since this matter is of immediate importance, the Executive Committee has directed its Chairman to seek the unanimous consent of the Conference to depart from the 1-year layover for such amendments that is provided in Section 10 of the Conference Organization and Procedure. Accordingly, I now formally request unanimous consent of the members of this Conference to consider at this time an amendment in this relation. (Those who favor such consent will respond by saying "Aye." If anyone is opposed, let him announce his "No.")

Unanimous consent having been granted, I now present for Conference action the language of this proposed amendment to Section 4. Officers.

The Director of the National Bureau of Standards is, ex officio, the President.

The Director of the National Bureau of Standards shall designate a senior member of the Bureau staff, who is thoroughly conversant with weights and mensures administration nationally, to serve the Conference as its Executive Secretary. 
Authority is granted to remove from the Organization and Procedure any inconsistencies that arise from this action.

(ltem 2 was adopted by roice rote.)

3. 'There ale a number of other provisions covered in the Conference Organization and Procedure that appear to the Executive Committee to require consideration. 'These are proposed to this 46th Conference in accordance with Section 10 for action by the 47th Conference in 1962.

(a) Section 3. Constituent Membership.-In order that due recognition may be afforded those weights and measures authorities who lare served the Conference in high elected positions or for many years and who later have retired from their positions in Federal, State, county, or city government, it is recommended that the advisory membership be extended by amending the third paragraph of Section 3, Constituent Membership, to read as follows:

Advisory membership comprises (1) representatives of agencies of the Federal Government who are concerned in any way with regulatory weights and measures officers or their official activities or who are interested in the objectives and activities of the Conference, and (2) each person wlo has retired from his Federal, State, county, or city weights and measures position and who, in addition, prior to his retirement, either has served the Conference as its President, Chairman, or Executive Secretary, or has attended as an active or advisors member 15 or more meetings of the Conference.

(b) In order that the duties and field of operation of the Executive Committee be more specifically set forth, and to avoid any questions as to its authority to act in certain areas, it is recommended that the fourth paragraph under Section 7, Duties and Fields of Operation of Committees, be amended as follows:

Executive Committee.-Subject to the overriding authority of the Conference itself, the committee selects the place, dates, and headquarters, and fixes the registration fee, for each meeting of the Conference, may at its option fill any racancy in an elective office of the Conference caused by death, resignation, or retirement from active official regulatory service, advises with the Executive Secretary with respect to the programs for the meetings of the Conference, reviews the general activities of the Conference and its committees and makes such recommendations to the Conference, the Conference officers, and the committee chairmen as it deems appropriate, and, in the interval between successive meetings of the Conference, authorizes interim meetings of Conference committees as the need therefor may levelop, authorizes committee and other contingent expenditures (including travel and subsistence expenses of committee members and the Conference Chairman), and acts for the Conference in all routine or emergency situations that may arise. Each new Executive Committee joins with the new chairmen of standing Conference committees in a breakfast meeting (as guests of the Conference) on the last day of the Conference, for general discussion and for transaction of business by the Executive Committee. Questions before the Executive Committee are decided, whether by voice vote or ballot, on the basis of the majority of votes cast.

(c) As has been explained in the Report of the Conference Committee on Laws and Regulations, it now considers its duties and responsibilities inadequately defined in the Organization and Procedure. To clarify this situation, the Executive Committee recommends that the sixth paragraph of Section 7, Duties and Fields of Operation of Committees, be amended to read as follows:

Committee on Laws and Regulations.-The committee annually presents a report for Conference action. Its field of operation embraces all matters 
within the area of weights and measures supervision that deal with the development and interpretation of model laws and model regulations, the study and analysis of bills introduced for legislative enactment, and the recommendations of general and administrative procedures, but exclusive of such matters as are within the jurisdiction of the Committee on Specifications and Tolerances.

(Item 3 was adopted by roice rote.)

\section{Meeting Place for the National Conference}

As recommended by the Executive Committee of the National Conference on Weights and Measures during its session held on the morning of June 10, 1960, the Conference Chairman appointed a special committee to explore the advisability of scheduling meetings of the Conference in localities other than Washington, D.C.

In considering the membership of such a special committee, it appeared that the entire membership of the National Conference would be best represented by the five principal oflicers elected from the active membership, namely, the Chairman and the four Vice Chairmen. These officers are not only elected by the Conference, but are well located geographically to represent the entire membership. The Chairman of the National Conference (and of the Executive Committee) assumed the chairmanship of this special committee. The Chairman and four Vice Chairmen are as follows:

R. E. MeEK, Indianapolis, Indiana

J. W. D. Harvex, Atlanta, Georgia

H. D. Robinson, Augusta, Maine

A. D. Rose, Bakersfield, California

J. D. Whlton, Dallas, Texas

The last previous study of the question at issue was made in $\mathbf{1 9 5 6}$ and 1957 by the Study Committee on Conference Organization and Procedure, and resulted in the following committee conclusion, which was included in the committee's report to the $42 \mathrm{~d}$ National Conference:

It is the feeling of the Committee that the place for the meetings of the Conference should be fixed by the Conference. Howerer, the Committee wishes to report its thought that, for the present, these meetings should be held in Washington, D.C. It may be noted in relation to the meeting place that the Committee thinking is in agreement with opinions expressed by the large majority of those who commented on this point in letters to the Committee.

The National Conference, by its adoption of the committee report, approved the quoted conclusion. Notwithstanding this comparatively recent action, the current committee decided that it would be helpful to develop a new consensus of those weights and measures officials who normally attend National Conferences. Accordingly, a questionnaire was sent to the head of each State weights and measures division and to the head of each city and county department that has been represented at the Conference in the last several years.

Recipients of the questionnaire were asked to vote "yes" or "no" on the following question:

Is it your opinion that the National Conference on Weights and Measures should be held annually in Washington, D.C.?

Those voting "no" were asked to give their suggestions "as to means of covering the many large and small arrangements and the 
costs of the meetings that are now borne by the National Bureau of sitandirids."

I total of 122 persons replied to the first question. Of this 1 mmber. 10.2 roted "res," 17 roted "no," and 3 expressed themselves in fitror of occasionally holding the meetings elsewhere than in Washington, in the event suitable ar'angements could be made. The 20 members who did not rote "res" are to be conmended for the sugwestions submitted with regind to arranging and finncing meetings if held elsewhere thin in Trashington.

In riew of the preponderance of the "yes" rote and the total lack of any unanimity of thinking relative to arrangements and financing in the erent of $\mathrm{X}$ ational Conferences being held elsewhere, the committee unamimously recommended that the Executive Committee contimue to schedule all National Conferences in Washington mntil such time as the question is again studied and the wishes of the active members of the Conference are again determined by an appropliate committee.

The subcommittee was of the opinion that this matter, including its recommendation, is one that is appropriate for the Conference to review from time to time-particularly in the event circumstances arise that cammot be foreseen at the present.

In view of the comprehensive study and the obvious soundness of the conclusions of the subcommittee, the Executive Committee concurred in the report of its subcommittee and now recommends to the Conference that its anmual meeting continue to be held in IVashington, D.C., until such conclusive evidence is submitted that would lead to further consideration.

('Tlis item was adopted by voice rote.)

\section{NBS Handbook 26, Weights and Measures Administration}

In order that the National Conference on Weights and Measures might be permitted to go on record formally with respect to the publication of and the principles set forth in the proposed revision of NBS Handbook 26, Weights and Measures Administration, the Conference Chairman accepted the responsibility of reading and studying the manuscript. As the result of this study and the Chairman's report to the Executive Committee, the following resolution is recommended by that committee for adoption by the Conference:

Whereas, there has been prepared by Ralph W. Smith of the Office of Weights and Measures, National Bureau of Standards, the manuscript of a revision to NBS Handbook 26, "Weights and Measures Administration"; and

Whereas, the original version of Handbook 26 has become a standard text in this field; and

Whereas, the Chairman of the 46th National Conference on Weights and Measures has carefully read and studied the manuscript and has formally recommended both its contents and its publication: 'Therefore, be it

Resolved, That this 46th National Conference on Weights and Measures urge the publication of the Handbook by the National Bureau of Standards and authorize the printing on the title page of the legend "Recommended by the National Conference on Weights and Measures": and be it further

Resolved. That the principles set forth in the revision to Handbook 26 are recommended by the Conference to all weights and measures officials and legislative bodies of States, counties, and cities.

(This item was adopted by roice rote.)

$61325 t-61-9$ 


\section{Conclusion}

The Executive Committee has been acutely arare of its responsibility to act for the Conference in the interim between regular meetings and is grateful for the opportunity thus afforded to serve. The National Conference on Weights and Measures is strengthened, and its influence is extended through the active interest, support, and participation of every weights and measures official and all representatives of affected industry and business. The committee commends to the thoughtful attention of all officials both the deliberations and the formal actions of the Conference and the implementation of Conference conclusions and recommendations through official action in their several jurisdictions.

R. E. Meek. Chairman
J. W. D. Harvey
H. D. Robinson
A. D. Rose
J. D. Walton
C. C. MoRgan
R. W. Searles
W. S. BUSSEX, Secretary
E. W. Buckun

H. H. Houston

Nathan Kalechiman

H. R. KENNELL

J. H. Lewis

J. F. McCarthix

Wilimait MiLLer

Joln Seres

Delbert Watratm

(On motion of the committee chairman, seconded from the floor, the report of the Executive Committee was adopted by voice rote.)

\section{REPORT OF THE SECRETARY OF THE NATIONAL CONFERENCE}

\section{W. S. Busser, National Bureau of Standards}

During the early years of the National Conference on Weights and Measures. it was the established custom for the Conference Secretary to make a report to the delegates annually. This custom ended with the 13th Conference in 1920, except for intermittent reports thereafter. It is believed that a renewal of the regular series of reports, covering items that are within the particular cognizance of the Secretary and that should be of general interest to the delegates, will be desirable to the end that the membership of the Conference may be kept informed.

Accordingly, this report is presented. It will be divided into two principal parts. The first will be a discussion of certain matters arising from the weights and measures operations of the States, counties, and cities. The second part will be a brief summary of the weights and measures activities of the National Bureau of Standards.

\section{Activities of the States, Counties, and Cities}

During the past year, weights and measures supervision seems to have made steady and continuing progress. Generally, there is being directed greater and more effective attention to the supervisory aspects of the work, especially in connection with the control of packaged commodities. This control, in a large majority of instances, has been based on the procedures set forth in NBS Handbook 67 . 
Interstate, and in certain instances intrastate, communication among weights and measures officials remains a serious problem. Somo attempts are being made toward a sohtion. A group of officials in certain sonthem jurisdictions have been experimenting with a weekly reporting system designed to keep each other advised as to commodities in package form that have been found improperly labeled or containing less than the qnantity represented. In other parts of the country certain neighboring jurisdictions also have been informing each other, but on a less frequent and less formal basis. It has been suggested that it behooves the Conference to seek a scheme of convenient exchange of information, countrywide, on noncompliance of interstate packages and on other faulty conditions in comnection with which interstate cooperation may better bring about corrective measures. Only thus can the effect of individual enforcement effort accumulate to a national program. It is my hope that the Committee on Education and the Executive Committee will give this possibility their careful and continued attention.

Another phase of package control that demands attention is the rariations in weight of a group of presumably nniform containers. Since the only reasonable control system for packages, it seems, is the gravimetric system, whether the product is being sold by weight or by liquid measure, the range of reights of the tares of a given lot of packages is highly significant. This is an area of activity that is being considered presently by the National Bureau of Standards.

The basis for the weights and measures program is, of course, the statute. During the past year sereral States have amended their laws, and the States of Tennessee and Alaska have enacted entirely new weights and measures laws, faithfully following, in all important respects, the Model Law adopted by this Conference.

Efforts of most States torard uniformity of specifications and tolerances have been outstanding. The provisions of the Conference codes, as published in NBSS Handbook 44, now have been promulgated officially by 39 of the States plus the District of Columbia and the Commonwealth of Puerto Rico. Most of the remaining States advise that their enforcement activities are being guided by the codes, but, for one reason or another, they have not seen fit to take official action.

The situation in package regulation also is commendable, but the degree of uniformity is somewhat less. The language of the Model Regulation lias been adopted recently in Tennessee, Washington, and perhaps elsewhere. Several other States have had the Model Regulation in effect for several years. The principles spelled out in the Model Regulation are in effect in many States in the form of food and drug regulations. These same principles have interstate status with respect to packages of foods, drugs, and cosmetics through the Federal Food, Drug, and Cosmetic Act.

Significant purchases of testing equipment by States, counties, and cities have been too numerous to permit listing here. There is increasing evidence of uniformity in this area also. The 30-pound "cube" weight kit, the small kit of cylindrical decimal weights, the small equal-arm scale for package checking, the Stabilene tape for testing fabric-measuring devices, the glass flasks for milk-bottle 
control, the graduated glass flasks for checking packages of liquids, the gage-glass 5-gallon test measure, and certain other items well known to those present have become quite standard among the many jurisdictions. 'This surely is a move in the right direction.

Testing procedures too are becoming more nearly standard. The States that conduct formal technical training schools have been guided in this connection by the NBS handbooks and the Test Procedure Outlines.

Although, as can be seen, there has been definite progress, there is room for much more. Many laws, both State and local, are obsolete and should be revised; many jurisdictions have provided insufficient manpower to do an effective job; the adequacy of testing equipment available for field inspectors is far from ideal; and the training of new and experienced officials has not, as a rule, kept up with the adrances in the technology of weighing and measuring.

\section{Weights and Measures Activities of the National Bureau of Standards}

Immediately following the close of the 45th National Conference, I was privileged to travel to England, Scotland. Northern Ireland, and nine European countries. The principal purpose of the trip was to attend and address the 1960 Anmual General Meeting of the British Institute of Weights and Neasures Administration on the subject of the Development of Weights and Measures Control of Packaged Goods in the United states. The chief weights and measures official in each of the countries risited was contacted. Numerous local oflicials also were visited in several of the countries. Studies were made of the office and laboratory facilities and procedures. Many field trips were made for the purpose of observing actual enforcenent techniques. This trip afforded an excellent opportunity to compare our activities and facilities with those of these other countries.

Technical raining has been a principal project of the Office of Weights and Measures. Since the last National Conference, staff members have conducted or have been major contributors in formal schools in the States of Indiana, Kentucky, Maryland, Missouri, New Mampshire, Ohio, and Tennessee. In other States, field training involving special equipment or directed to the solution of special technical problems has been undertaken.

The genesis of a training eflort of a very special character has been reported on by the Chairman of the Conference Committee on Education. This, of course, was the first technical training course for instrnctors in weights and measures supervision. It is sufficient here to comment that. from the standpoint of the National Burean of Standards, this school was quite successful. The 13 students were able, apt, and enthusiastic. Additional courses of this type will be offered if and when there appears to be sufficient demand for them.

Another project of the Oflice of WVeights and Measures that has received major attention during the past 12 months is the deve]opment of new State Standards. This has required research on materials, experiments on designs, composition of purchase and performance specifications, and comprehensive testing.

Undoubtedly the most startling, and at the same time the most satisfying, result has been design and fabrication of high precision 
bilances of the one-pin. seminutomatic type for weighing loads up to 50 pounds.

l'rowess on the new State standards has been satisfactory, and the establishment of a time schednle now is feasible. Depending entirely npon the acceptability of the program to the Administration aid the willingness of the Congress to appropriate necessary funds, it now appears that it will be practicable to have the first complete sets of standards and instruments tested and ready for delivery by mid-1963.

These stanclards and instruments will be snch that, if adequate space and properly trained personnel are provided, the State weights and measures laboratory can become, in reality, the measurement center for the State-for business, industry, education, and technology.

The staff of the Office of Weights and Measures has continued its policy of participating in each State and regional weights and measures meeting. Correspondence and other requests for consultation have occupied considerable staff time, and the aim has been to give prompt attention to each request.

The new siainless-steel prover for liquid meters dispensing liqnid fertilizer's has been designed, fabricated, and delivered, and now is awaiting test. The power-operated dolly for moving 500- and 1000-pound test weights has been completed, and drawings for production are arailable on request. A special weight study for the tobacco industry has been planned and will be pursued shortly.

The Weights and Measures Library is progressing nicely. Organization of the shelves and accessions of valuable documents have been most satisfactory. The detailed subject and author index of all archival volumes except periodicals is complete, and the index of the periodicals is now under way and should be completed by the end of this calendar year.

Another indexing operation of significant proportions that recently has been completed is that involving the Reports of the National Conference. The last previous index covered Reports through the 36th Conference (1951). The one now in press will include all Reports through the 45 th Conference.

In the future. as in the past, the policy of the National Bureau of Standards will be to make its services available on a "request" basis, and it will be the aim of the staff to fulfill requests falling within its authorized area of activity to the full extent of the persommel, facilities. and funds available.

Looking to future facilities, there is anticipated serious crowding for the next few years and then an ideal situation. In the planning for the new Bureau facilities at Gaithersburg, all possibilities in the foreseeable future have been considered. The weights and measures activity will occupy excellent quarters on the serenth floor of the Administration Building, with an efficient office layout, a combination library and conference room, an engineering area, a modern training laboratory, and a model State laboratory.

Speaking generally, the weights and measures officials of the Cnited States and affected industry and business can look forward to increasing technical assistance from the National Bureau of Standards. 


\section{WEIGHTS AND MEASURES IN CENTRAL AMERICA}

By A. E. Diaz, Head, Weights and Measures Division, Economic Stabitization Administration, Commonwealth of Puerto Rico

This paper, for which I could use the title "A long way from standards," is a short story about the weights and measures situation in a group of countries that are working hard to rebuild their economy by means of an integration program. In planning that program, the importance of the standardization of weights and measures was recognized.

For our purpose, Central America is the geographical name applied to the strip of land connecting North America and South America, but excluding British Honduras and Panama. 'Thus modified, Central America consists of an area of 190,761 square miles and had a population of over nine million, estimated as of 1955 . This population is racially diverse, and the proportion of each racial element varies from country to country. For the whole area the Indian and mestizo (mixed Indian and European) elements are each far superior in members to any of the other groups.

Agriculture dominates the life of the greater part of the population in Central America. On the commercial scale, coffee and bananas outweigh all other crops. As far as foreign trade is concerned, the role of the United States is the dominant one.

Up to the first half of the 19th century the Spanish system of weights and measures was predomimant in the five Central American countries. From the beginning, these countries have lacked uniformity in the mits of weights and measures, especially the units of length. Apparently, the absence of reference standards is responsible for the introduction and use of units whose values differ among the countries and sometimes even within a country. For example, the Spanish unit "cuerda" used for land measurements has six different values in Gnatemala depending upon the section of the country where the measurement is made. In addition to the Spanish system, the population still uses native units which also lack uniformity.

The units of weights and measures used in England and in the United States were also introduced into Central America.

As a result of the international conventions for the adoption of the metric system, the Central American countries enacted laws for the mandatory use of metric units of weights and measures. Costa Rica was the first one to adopt this system in 1881 and Guatemala the last one in 1910. In spite of those promulgations, which recognized the metric system as the only legal system of weights and measures, the situation today is far from standardization. Metric units account for only 12 percent of the total units in use, while native units represent 50 percent, and Spanish and English 19 percent each. The metric system is almost exclusively used by the Customs Service, mail, and railroads.

For commercial weighing the Spanish "libra" is used, and textiles and land are sold by the "vara." The "vara" is equivalent to 36 Spanish inches; its values in Costa Rica and El Salvador are the same, but this value differ's from the accepted equivalent in the other three republics. 
I collere grower in Central America pays for picking the harvest by the Spanish "libra." his export duties on it are paid by the kilorram. and he sells it abroad by" the avoirdupois pound. "While in Costa Rica a bushel of corn is equivalent to 768 Spanish "libras," in El Salvador it is equal to 200 "libras" and in Nicaragua to 310 "libras." Complicated, is it not?

That about inspection and testing for weighing and measuring derices? There is practically no control at all. Although a Central Imerican Convention, ratified by the five republics, provides for the establishment of national services for weights and measures administration, nothing has been done yet. There are some areas where weights and measures registration offices are established at the municipal level. But these offices, which work on a fee system, exist mainly as a source of income rather than in the interest of accuracy. For instance, in Guatemala City a home-made smallcapacity scale that costs approximately 75 cents pays an annual registration fee of $\$ 1.00$. In the case of a gasoline dispenser, the fee amounts to $\$ 36.00$. How much importance is given to accuracy is evidenced by the inadequacy of the testing equipment used and the specifications applied, which are practically none.

Worried about this situation that so seriously affects the international trade and the possibilities of the Economic Integration Programme, the Central Banks requested the Committee on Economic Cooperation to take action on the matter of the standardization of weights and measures. This request initiated the train of events that eventually put the Technical Assistance Programme of the United Nations to work.

From that point on, the standardization of weights and measures in Central America has been considered of paramount importance as part of the preparations for the Common Market, under the Economic Integration Programme.

I was asked by United Nations to go to Central America in an adrisory capacity. In each republic a counterpart was appointed to cooperate in the drafting of a weights and measures bill and regulations. TVith their assistance, a series of interviews were held with leaders in commerce, industry, and government to explore their reactions to the exclusive use of the metric system and the creation of national bureaus for the enforcement of the weights and measures law and regulations.

The idea of standardization based on the metric system was accepted. With respect to the weights and measures bureaus, some government officers appear to endorse a municipal program instead of the proposed national bureaus. The reason for this seemed to be that in these countries weights and measures administration has existed at the municipal level only and also because that service constitutes a source of income to the municipal treasury. It was also claimed that a national program would be too expensive and that the present situation would not permit the development of such a program. These expressions did not represent the points of view of the majority; however, the economic significance of the weights and measures control program was underestimated by most of the officers.

After consultation and discussion with my official counterparts, a proposed uniform bill of weights and measures was drafted. This 
bill establishes the mandatory use of the metric system, appoints the Central American Research Institute for Industry as custodian of the internationally certified standards, and provides a weights and measmes control program at the national level.

Proposed uniform regulations dealing with units of weights and measures and specifications and tolerances for weighing and measuring devices were also drafted.

Another proposal was prepared regarding the establishment of a regional office of weights and measures, that is, a Section at the Central American Research Institnte for Industry, located in Guatemala City, that would supply standards and technical assistance to the national bureans. This Institnte is sponsored by the United Nations and operated by a board of directors composed of the Ministers of Economy. As it is contemplated to establish the national weights and measures bureans in the ministries of economy, the Weights and Mensules Section at the Institute would play an important loole in helping these bureaus to attain efliciency, and at the same time it would be less costly than operating separate national laboratories.

In regard to the establishment of the standards laboratory at the Institute, arrangements were made with the U. S. National Burean of Standards for the formulation of specific recommendations. To that end, the Bureau sent Dr. I. T. Judson to Guatemala City for a. survey. Later, a comprehensive report was rendered.

Another phase of the proposals was the preparation of a working plan for accomplishing the change to the metric system. It was suggested that the execution of the plan be assigned to a special committee composed of members representing consumers, industry, commerce, and govermment. This committee would establish important policies such as a schedule of priorities for the changeover and duration of the transition period.

These are, in general, the ways and means for the standardization of weights and measures in Central America that were submitted to the consideration of the Economic Commission for Latin America. 'The final action depends now on the governments, through their Committee of Fconomic Cooperation.

With respect to this final action I would like to point ont the following:

The executim of the program herein described contemplates the standardization based on the exclusive use of the metric system. As stated before, this poganul was accepted as an urgent nocessity, but opinions about the possibilities of success of such a program are divided. Among the pessimists there ale some who aflim that this could not be done mnless the United States and lingland change their systems too. Another soup aroues that the Indian population presents a serions problem of education if the proposed change is aropted. Expenditures for now weighing and measuring devices and reconditioning of the ones in use are factors also mentioned.

The consideration of these argmments reminds me of India. In my opinion, the situation in India is even worse, and yet the changeorer to the metric system is making continuous progress. And next to the south Border of the Inited States there is Mexico, a country with nore or less the same conditions as Central America, but Mexico succeeded and is now a metric country.

It seems to us that the changeover in Central America would be less expensive than what is normally expected because there are no 
requilements for specifications and tolerances.. This allows for the nse of a considerable anount of inexpensive weighing and measuring derices, so their rejection or seiznre would not result in a serious economic loss.

'The assigmment for standardization on weights and measures came to an end." It this point ron might ask, "What is finally going to happen in Central America in regard to weights and measures administration?" Central Anerica will go metric, all the way. I do not know exactly when, but it will happen. Progress in that activity will be in direct relation with the derelopments for the Common Market and the Integration Programme. 'The change to the metric srstem will require the establishment of the national bureaus. And those enforcenent agencies will establish certain requirements applicable to reighing and measmring devices. United States manufacturers would probably receive most of the orders to satisfy the new needs for nime million inhabitants. Or it might be that some manufacturers will decide to open plants somewhere in the region to take adrantage of the ax incentive programs for new industries.

In the meantime the Central American Research Institute for Industry is trying to get full control for the continuation of the weights and measures standardization program. The Institute is in a position to contract the services of a weights and measures expert on short notice and with flexibility as to the duration of the assigmment.

But the important thing is that all this activity will bring Central Imerica to a meeting point with us, in our goal-to see that equity prevails.

In closing this paper, I wish to express my appreciation to the Office of Weights and Measnres of the National Bureau of Standards for its splendid cooperation in the fulfilment of my assignment with the United Nations.

\section{Discussion on ForEgoing PAPER}

Mr. Rose: Does anyone liave any questions he would like to ask Mr. Diaz?

Mr. RHerx: How great a problem is there going to be to reeducate for the metric system? And secondly, how much resistance do you expect from industry?

Mr. Dr.z: As to the first question, any well coordinated program of education that is established must stimulate the public and prirate schools so that they will teach and apply the metric system, so that the younger segment of the population would be edncated for the changeover. The program for the older population will require a lot more effort. In general, the education program is a tremendous job.

As to how much resistance, I would say that there would be as much resistance and to the same extent that human nature usually resists change. But in this case the necessity for the changeover has been accepted, and this will help to orercome the resistance.

Mr. Turnedul: Mr. Diaz, do you think that, if the United States and Great Britain were to adopt the metric system officially, this rould aid the adoption of the metric system in Central America?

Mr. Diaz: Yes, I believe so. 
Mrr. J. G. Lewis: You indicated that there have been several surreys and reports made. Has there been any estimation of the cost and the length of time for the transition to the metric system?

Mr. Diaz: Nothing has been estimated that I know of. It is known that this is going to be a costly program.

Mr. ScHmes: I thought I would like to make the report that every baker who goes through the baking school is well aware of the metric system and well schooled in it.

\section{A NEW APPROACH TO WEIGHTS AND MEASURES CONTROL}

\section{By G. P. Larrick, Commissioner of Food and Drugs, U.S. Department of Health, Education, and Welfare}

It is a pleasure to be with you again and to have the opportunity of considering matters of mutual interest with you.

Mr. Bussey has told me of your interest in what is being done, and what more can be done, working in cooperation with you to correct violations of the law involving incorrect and inconspicuous declarations of the quantity of contents of packages of foods, drugs, and cosmetics. At your meeting last year we reported on a nationwide survey made specifically to obtain information on this subject and we supplied to all who were interested a tabulation of our findings. This involved 106,695 food packages in 35 different commodity groupings.

This special survey differed from our normal and usual approach which involves the routine checking on quantity of contents on samples collected for examination for any otler violation plus follow-up on any specific complaint received from the trade, consumers, or cooperating law enforcement officials. For the purpose of giving you up-to-date facts on the results of such routine activities, we reviewed our file for a 12 -month period from April 1960 to April 1961. During this period our laboratories routinely examined all samples for quantity of contents. WVe found serious shortages that required seizure of 14 shipments of foods, such as: coffee, bakery products, honey, confectionery and seafood.

In addition, we have under consideration several other samples where there were shortages. A criminal prosecution case filed somewhat earlier and based on spices adulterated with buckwheat hulls and packaged short weight was terminated late in 1960 with a fine of $\$ 1,000$.

In our routine enforcement actions (as well as in some flagrant cases which are handled separately), we are on the alert for violations of the provisions of the law calling for conspicuous declaration of required information including quantity of contents statements. Canada recently amended its regulations to require such declarations to appear in boldface type of specified size for each of four different defined total label areas and the statement is to appear on the main panel of the label "Or any panel othel" than the bottom of the package." This will, of course, affect many firms in this country shipping their products to Canada. Our regulations do not carry this specific requirement, but as you know, we have continued to advise inquirers that to insure compliance with our law mandatory information should appear conspicuously on the principal display 
panel of the label. Firms that elect not to follow such advice do so on their own responsibility and under such circumstances it is necessily to make a detemination on the basis of the facts in each particular instance as to whether we believe we can establish that the law has been riolated.

Frequently we uncorer serious economic cheats that do not fall in the weight shortage area but rather in the weight or volume increase area-for example, due to the addition of water-one of the oldest and most profitable forms of adulteration. After a two-week trial in Texas last month the Court found a Houston firm and those responsible for its operation guilty of shipping watered and sweetened orange juice labeled as fresh orange juice as nature made it, with nothing added. The product was actually only about one-half orange juice. The convictions resulted from long and painstaking work by our inspector's, who used field glasses and cameras to get evidence on the surreptitious operation after laboratory tests indicated that the product was being adulterated. Whenever inspectors made regular inspections the hidden sugar could not be located and the plant always promptly started packing pure orange juice. From a nearby rented apartment they later observed an ummarked truck delivering sugar to a shed toward the back of the firm's premises from which it was carried by bucket brigade into the plant. Still later eridence was uncovered showing cash purchases of over 750,000 pounds of sugar by employees who were permitted to carry no identification. Total fines assessed by the court amounted to $\$ 20,000$ and in addition the firm's officials received prison sentences which were suspended except for one official who must serve six months. These officials also have yet to stand trial for perjury during testimony in their own behalf and an injunction order was signed in May to stop further violations.

It your June meeting last year, Mr. Hubble of our Bureau of Enforcement related some of the difficulties we have been having in enforcing the prohibitions of the law against deceptively packaged foods, drugs, and cosmetics, and described the Delson Candy Company chocolate covered thin mints case that had been contested by the owner of the goods. You may recall that it involved a rectangular package with hollow ends and hollow dividers on which there was an accurate net weight statement, but in which the candy occupied only $34 \%$ of the cubic content. It contained only 30 mints whereas the package could hare held 41 except for the hollow ends and dividers.

The lower court decision, which was unfavorable to the Government, was appealed to the Third Circuit Court of Appeals. The unanimous ruling of the three-judge court in effect states that food cartons may not be larger than reasonably necessary to protect the contents from damage, taking into account the alternative methods of protection available. Three principal concepts are developed in its opinion.

(1) That the consumer has a right to expect that a non-transparent container of food is reasonably full;

(2) That the size of the container is a reliable index to the amount of food in the package; and

(3) That the package is not filled with excessive padding. 
The case has been remanded to the district court judge for reconsideration and findings consistent with the law and the facts. TVe propose to step up onr regulatory activity against deceptive packaging if the matter is finally adjudicated favorably to the Government. This, of course, will be a long step forward in consumer protection.

All of us are anxious to see both the Federal and the State or local laws with respect to weights and measmes enforced as effectively as possible.

From the facts in onl possession, despite the number of legal actions we have taken since 1959 , there are indications that there are still too many occasions in which a mannfacturer produces and markets foods that are short of the declared weight or volume. TVe note that a number of you have also reached the conclusion that something more needs to be done to give adequate consumer protection.

I wish I were in a position to tell you that the Food and Drug Administration is prepared to increase many-fold the effort it will put in to investigation of short-weight practices during the coming year. I cannot give you this assurance. We still have many health problems that require attention. The funds under which we are operating this rear and the funds that we have requested for the following year do not provide for sufficient inclease in weights and measules work to give any degree of assurance that we will begin to control the problem adequately with resonices available to the Federal Government.

Tre know that you also are limited in the amount of attention that you give to the problem.

So the question now is: "What can we do with our limited resources to increase significantly the protection that the consumer gets in the reights and measures field?" The have a suggestion for your consideration which may vield real benefit. And it is based upon experience that we have had in another field-the animal feed area.

Orer a period of years we have had insuflicient manpower to do as much work in checking the accuracy of label claims for protein, fat, and other components of animal feeds as might be desired. Many States had good programs.

Bit a State, acting moler its laws, often was mable to force a mannficturer in another State to make fundamental correction of bad practices. So we commissioned many State feed control officials as agents of the Food and Drug Administration for the purpose of collecting and examining samples of foods originating ontside their States. Then such examinations have shown significant shortages in feed nutrients, the States have forwarded the facts to uls and rie hare been able to bring action, either seizmre or prosecution, under the Federal law for the violations detected. We have been mable to reimburse the States for their time and expense in this endearor but I believe they are sitisfied that the benefit to their citizens far outweighs the relatively minor expense of the cooperative effort in which they have engaged.

In several States the principal officials responsible for weights and measures enforcenent work already hold similar commissions from us. We would welcome requests for such commissions from other officials responsible for this type of work in other States. The would 
like to see a concerted nationwide effort by the State oflicials and the Food and Drug Idministration to stamp out the shipment of shortweight merchandise. If rou can help us by detecting the cheats that are being perpetrated within your State borders by firms who escape rom jurisdiction becanse they are located in another State, we can help you by bringing legal actions where indicated.

Tre should add one precantionary note: Under the Federal law we may take action against prodncts that are short weight when shipped. In many instances simple net reight determinations at point of sale will not be enongh to establish a riolation.

If you think well of the idea, perhaps you will wish to name representatires to help work out the details of a joint program. Tre hope you will look with faror npon our proposal and that our coordinated efforts will result in a substantial reduction in short-weight and short-rolume foods in the American market place.

\section{DISCUSSION ON FOREgOING PAPER}

Mr. Bowkx: Mr. Larrick, this is purely hearsay, so I will mention no names. but it seems a case rather akin to the package of thin mints. This is an instance of a 5-cent candy bar which is in a wrapper that appears to be the old-style package, but the candy bar itself is about as big as one little finger.

I have been told (and this is where the hearsay part comes in) that that particular candy company has installed an air-blowing machine which blows up the envelope surrounding the candy bar. Whether or not this is so, I do not know. It appears likely from the appearance of it. Have you come across anything of that sort?

Mr. Lirrick: I have not, personally. Bear in mind that we have had three cases on deceptive packages where the defendant vigorously opposed the prosecution. We have brought many, many cases wheie the firms did not fight, but in three cases they did fight, and in all three cases in the lower court the Government lost, and that is quite unusual for the Food and Drug Administration. We usually win about 96 percent of 011 cases.

I strongly suspect that one reason that we have not impressed the Federal judges is that most of our cases hare been on candy, and if we win this Delson case I hope that our next cases will be on items that are quite important in the staple food items of the American diet. But I would say, if we win the Delson case and you were able to take the hearsay out of the facts that you talked about and let us know what firm is suspected. we will send an inspector there and, if they are blowing it up, we will bring a case.

Mr. Runs: Mr. Larrick, in the last several weeks we are getting bananas in boxes from the Dominican Republic and Honduras with absolutely no designation of who is responsible, what are the contents. or anything else. I did refer this matter to your Cincinnati office. I was wondering whether anybody else has come across these. They are bringing them in by boat all the way to Cincinnati.

Mrr. Larrick: I am particularly glad to get a question from you, sir, because I started my food and drug career in Cincinnati in 1923, and in the days when I really knew something about food and drug inspection I worked closely with your people.

I have no personal knowledge of this matter. If you referred it to the Chief of the Cincinnati District, I feel confident that the 
matter will be taken care of, and if it is not I will look into it personally if you will let me have a note.

Mr. Meek : Commissioner Larrick, I want to compliment you for the splendid suggestion that you have made. I think it will be workable. I think we could participate in it. I think we have been following that procedure to a considerable extent over a period of a long number of years in Indiana. As an illustration, when one of our local or State inspectors reports to us his findings with regard to short weight or measure on a product manufactured in another State and shipped into Indiana, we report that to the Food and Drug Division. Fortunately, we are located close together in Indiana in the State Board of Health, and if the director of that division is unable to work it out he brings it to the attention of the Federal Food and Drug Administration. I expect you will recall it has been done on a number of occasions. I am wondering whether you have the close working arrangements between the weights and measures and food and drug administration in other States. Would there be any advantage that I be commissioned by you, when I have the very close relationship with the Indiana Food and Drug Division?

Mr. Larrick: I would think that the answer to your question would be that we would be bound by whatever decision you made about how you wanted the relationship to work out. If you prefer to channel it through some other officer who is already commissioned, I think that would be all right, but if you would like to have the State weights and measures people commissioned we would be happy to do that.

We do not want to dominate the States or the cities. We just want to offer an opportunity to join in this program of commissioning that we think is highly desirable. This all fits into a comment from your able friend here, Mr. Bussey, that he wants to build a strong relationship among all of the agencies-Federal and Statethat have the position of leadership in this important field of consumer protection.

I think we all ought to take advantage of the current philosophy of the Congress and the pendulum swing in the direction of protection of the American consumer. I have been in this work 38 years and I have seen the pendulum swing only twice in the direction where economic violations were really importantly considered by the Congress and by the public, and I think that we all ought to cash in on this opportunity to strengthen our laws, to get more appropriations, to upgrade the caliber of people whom we have at the Federal, State, and city levels and to really build for the future in consumer protection.

Mr. Lyles: I was wondering, Mr. Larrick, are the requirements of the Food and Drug Administration as to solid versus liquid canned goods such as canned corn and peas, where you have a considerable amount of liquid in the commodity itself, set forth?

Mr. Larmick: In general, the rule we have followed is that we will, in the first place, establish for important staple foods a standard-of-fill of container that prescribes a relationship between the packing media and the food product, but again, in general, if the packing media is nutritious and consumed it can be declared as 
part of the net weight or volume. If you want more details on that, I will call on my expert here, Mr. Beacham.

Mr. Kerlis: I would like to have Mr. Beacham elaborate just a little on this added liquid.

Mr. Beschas: TVe have two problems. First, an accurate statement of the quantity of contents is required, and for practically all foods the statement of contents includes both the liquid and the solid portion. Then we have a question of the relationship of the solid material, being the more valuable portion of the food, to the least raluable portion, msmally the liquid portion. That is usually taken care of by a means of standard-of-fill of the container, and we have established such standards for some foods. But there are a. great many foods for which we have not established any such standard, and here is an area where abuse can exist and does exist, in that food, which is accurately labeled as regards the total quantity of contents, is really not properly packed if there is an excess of packing medium present. That matter must be taken care of by a standard of fill of container.

Mr. KerLix: Has a standard of fill been established for potatoes?

Mr. BEachàr: No. If my recollection serves me right, we do not have a standard of fill of container for canned white potatoes.

Mr. KÉrLIN: Can we do something about that?

Mr. Beachas: We can establish such a standard if we have the technical facts to support it.

Mr. KERLIN : Frankly, 7 ounces of potatoes in a 1-pound can, especially when very few people use the juice of the potatoes, is a little ridiculous.

Mr. Beacham: I am inclined to agree with you. In canned food, a rough rule of thumb is that the solid portion of the pack will be two-thirds of the total content of the can, with one-third liquid medium. In the case of 7 ounces of potatoes and 9 ounces of liquid, we do not have that ratio. That would indicate it contains excess liquid.

Mr. KerLin: What would be your recommended procedure, so we can get something done?

Mr. BeACHAM: An examination of what should be the proper relationship between the solid portion and the liquid portion would involve putting up experimental packs and a study of the relationship of the effect of the size of the potatoes. I am guessing that perhaps you could get more small potatoes in than you could large ones. You would have to investigate this carefully and see whether a single standard fill of container would cover all sizes or whether there would have to be variations in the requirements to meet the changes that size would impose.

Mr. Kerlin: One other question: Under your rules and regulations, if a package is labeled "Net Weight 1 pound," and then an added statement "includes added water" or some such statement appears on the label, would this be legal?

Mr. Beacham: On unstandardized food, the statement of water added would be unnecessary, because there must be a statement of all of the ingredients. If they put in an accurate statement of quantity of contents, that would take care of that obligation of the law. 
If we had a standard of fill of container, establishing the relationship between the solid and liquid portion, then a statement that there was excess water would not excuse that failure to meet the standard. Where standards of fill of container are established, there usually is a provision for labeling substandard products that do not meet the standards, and in that case there might be a prescribed statement snch as "substandard in fill" or "contains excess liquid," but that would be dependent upon the terms of the standard.

Mr. LARrick: I would like to point out that we have to make a choice rely often as to what areas we will work $\mathrm{in}$. The have had at the beginning one man to work on food standards, and there are thousands of them to be dealt with. We increased that to three, and unfortunately one of them no longer is with us. TVe have the task of deciding where we will denote our limited resources.

For example, today there came orer my desk a case that involves a large firm in Chicago that buys physicians' samples of drugs in the thousands of dollars' worth, and we discovered by sampling their material that they have gotten mixed up and, in place of a simple ritamin pill that the label says is in the package, they have substituted a drug which is extremely dangerous.

We have the whole field of health and filth and economic cheats, and I am sorry to say that we have not been able to move as fast in this economic cheat field as we would like to, but, as we increase on facilities (and we are). we are going to step it up. I suspect that the example that you have given, if the facts are as you have stated them, is an example of an area that we should get busy on.

\section{REPORT OF COMMITTEE ON SPECIFICATIONS AND TOLERANCES}

\section{Presented by C. I. Jacksor. Chaiman. Chief. Division of Economic Practices, Department of Agriculture, State of Tisconsin}

('rior to the presentation of the formal report of the committee, Mr. Jackson made the following informal statement.)

It is the purpose of this report to bring abont a full understanding of the ralious items before the committee and of the several issues inrolved in each of them and, in addition, to present the recommendations of the committee for action by the Conference. I want to emphasize that free and open discussion is welcome. I must cantion, however, that cale must be exercised in the consideration of each item. Individuals should be deliberate and should not be too hasty in attempting to make final judgment, under pressure, without considering all factors that are involved.

It is the feeling of the committee that any matter that merits the committee's attention should be thoroughly studied both by the committee and by the members of the Conference, who will make the final decision. There will be a reluctance on the part of the committee rnembers to agree readily to a change in the final report, since any such change obviously will not have been given a careful analysis.

('lhe formal report of the committec follows.) 
In order to atrord the opportunity for orit presentations to the committee and in order that the conmittee might discuss in detail the nuatters on its agendal, an interim meeting of the committee was held in Wishington, D.C.. Jamuary 30 and 31, 1961. During the open sessions of this meeting, representatives of business and industry and woinls and measures oflicials presented themselves before the committee and made known their recommendations. In addition to this meeting. consultation among committee members and between the committee and reights and measmres oflicials, industry representatires. and others has been carried on by correspondence.

I tentative report was prepared by the committee and this was distributed widely. It an open hearing held on the afternoon of Mondar, Jume 12. at the headquarters hotel, the tentative report. was oftered for discussion, item by item. The hearing was well attended and numerous comments were made and suggestions were offered reltaire to the tentative proposals of the committee. These matters were further considered at an executive session of the committee following the open hearing.

Presented below are the final recommendations of the committee, together with appropriate comments, gromped under the code heading as found in Handbook 44, 2d Edition, as amended through the t5th National Conference.

GENERAL

The torth National Conference, in 1960, adopted a recommendation of the Committee on Laws and Regulations that the Mode! State Weights and Measures Law be so written as to exclude from the "commercial" category those devices that have been considered commercial only because a charge is made for their use and over which no commodity, thing, or service is bought or sold (for example. penny person weighers). The Conference then directed the Specifications and Tolerances Committee to include in its tentative report the amendments to the Handbook 44 codes that would be necessary to make these codes compatible with the Model Law. Such amendmients are listed belon.

\section{General Code}

Application paragraph G-A.1. CoxmERCIAT EQUIPIENT.-Delete the clanse starting with the comma in the next-to-the-last line.

sicule code

1. Application paragraph A.2. COMLMERCIAL PERSON WEIGHERS.Delete entire parigraph.

2. Definition paragraph D.17. PERSON WEIGHER.-Delete entire paragraph.

3. Specification paragraph S.1.7.3. ADJUSTuENT.-Delete, in lines 2 and 3 , "a person-weigher or".

4. Specification paragraph S.1.7.4. LEVEL-INDICATING MEANS.-Delete, in line 2 , "a person weigher, or off". Also delete the comma in line 3.

5 . Delete the center head that follows paragraph S.22. on page 56a.

6. Specification paragraphs S.30. through S.36.-Delete these seven paragraphs.

†. Regulation paragraph R.13. REAl)ABIL1TY OF RECORDED REPRESENTATIONS OF PERSON WEIGHEIS.-Delete entire paragraph.

S. Regulation paragraph R.14. OWNERSHIP IDENTIFICATION ON PERSON WEIGHERS.-Delete entire paragraph.

\section{DISCUSSIOY OF FOREGOING ITEM}

Mr. J. T. Kexnedr: In the District of Columbia we must consider a person-weighing scale as a commercial scale. Although only one 
cent is charged for service, there is involved a payment for the weighing service. Accordingly, as far as the District of Columbia is concerned, we cannot adopt these amendments.

(At this point Mr. Meek, the Conference Chairman, assumed the chair.)

(On motion of the committee chairman, seconded from the floor, this item was adopted by the Conference by roice rote.)

GENERAL CODE

The committee has noted that general application paragraph G-A.1. COMMERCIAL EQUIPMENT, the paragraph that sets forth the general area in which the codes are to be applied, makes no mention of either devices for use in law enforcement activities or noncommercial devices being tested upon request, whereas, with respect to certain specific classes of scales, both of these categories are mentioned in the Scale Code in application paragraph A.3. WHEFLLOAD WEIGHERS, WHEEL-LOAD SCALES, AND AXLELOAD SCALES. To clarify this situation and to simplify the language of the paragraph, the committee recommends that the general application paragraph $\mathrm{G}-\mathrm{A} .1$. COMMERCIAL EQUTPMENT be amended to read as follows:

G-A.1. COMMERCIAL AND LAW-ENFORCEMENT EQUIPMENT.-These specifications, tolerances, and regulations apply (1) to commercial weighing and measuring equipment, that is, to weights and measures and weighing and measuring devices commercially used or employed in establishing the size, quantity, extent, area, or measurement of quantities, things, produce, or articles for distribution or consumption, purchased, offered or submitted for sale, hire, or award, or in computing any basic charge or payment for services rendered on the basis of weight or measure; and (2) to weighing and measuring equipment in official use for the enforcement of law. (These requirements should be used as a guide by the weights and measures official when courtesy examinations are made, upon request, of noncommercial equipment.)

(The General Code amendment was adopted by voice vote.)

SCALE CODF.

1. Application paragraph A.3. WHEEL-LOAD WEIGHERS, IVHEET-LOAD SCALES, AND AXLE-LOAD SCALES.-For reasons explained above, delete the last clause of this paragraph, making the paragraph read as follows:

A.3. WHEEL-LOAD WEIGHERS, WHEEL-LOAD SCALES, AND AXLELOAD SCALES.-The requirements for wheel-load weighers, wheel-load scales, and axle-load scales apply to such scales in oflicial use for the enforcement of traffic and "highway laws.

(Item 1 of the Scale Code was adopted by voice vote.)

2. Definition paragraph D.1\%. PREPACKAGING SCALE.-The Southern Weights and Measures Association recommended that the committee consider a new and more extensive definition of "prepackaging scale." The committee has given this recommendation its very careful study and has consulted weights and measures officials and representatives of industry. No instances of misunderstanding or confusion have been found. While it is frequently possible to make minor improvements in language, the committee feels that no appreciable benefits would accrue from any rewording of this definition 
paragraph that has been proposed or that the committee has been able to develop. The committee, accordingly, recommends no action.

(Item 2 of the Scale Code was adopted by voice rote.)

3. Definition paragraph D.3\%. TELL-TALE ATTACHMENT; regulation para graplis R.4.2. ON LIVES'TOCK SCALES and R.4.4. ON TEHICLE, THEEL-LOAD, AND AXLE-LOAD SCALES.The committee believes that the "tell-tale attachment" defined in definition paragraph D.3T. and in regulation paragraphs R.4.2. and R.t.4. las very little, if any, national significance in commercial weighing. The rery limited use of these devices appears to be quite localized. Since the definition and the references in the two regulations have been and are cansing confusion and lack of understanding among weights and measures officials, and since it is obvious that this special attachment for a large-capacity scale does not play an important nationwide role in commercial weighing, the committee recommends that all references to it be deleted from the Scale Code, as follows:

Definition paragraph D.37. TELL-TALE ATTACHMENT.-Delete entire paragraph.

Regulation paragraph R.4.2. ON LIVESTOCK SCALES.-Delete last sentence.

Regulation paragraph R.4.4. ON VEHICLE, WHEEL-LOAD, AND AXLELOAD SCALES. - Delete last sentence.

(Item 3 of the Scale Code was adopted by roice vote.)

4. Specification paragraph S.13.3. LABEL RECORDER.-The Southern Weights and Measures Association has recommended that specification paragraph S.13.3. be rescinded in order to permit "analog" weight representation of weights on labels issued by a prepackaging scale. This recommendation was endorsed by the Scale Manufacturers Association.

This matter was thoroughly explored prior to and during the 45 th Tational Conference. The Conference then adopted the amendment represented by specification paragraph S.13.3., and presented as part of its reason: "It should be kept in mind that, when a prepackaging scale prints weight values and money values directly on a package label, such printing must be so as to meet all legal requirements for package marking."

Nothing has been presented to the committee that would alter this viewpoint and, in reference to the recommendation, the committee reiterates the obligation of Handbook 44 to prohibit devices the use of which might be construed as being in violation of other phases of weights and measures law.

The committee has been reliably informed by the scale manufacturers most affected that necessary engineering and production alterations cannot be completed by the effective date presently stipulated in the code; accordingly, the committee recommends that specification paragraph S.13.3. LABEL RECORDER (Scale Code, page 56, Handbook 44) be amended by changing the date "July 1, 1961" appearing in the first line of the paragraph to read "March 1, 1962."

(Item 4 of the Scale Code was adopted by voice rote.) 
5. Tolerance paragraph T.2.1.2. TO SIIIF'T TESTS.-For many years the code has provided a special tolerance applicable to shift tests on vehicle scales which reads as follows: "On a vehicle scale the tolerances on corner tests shall be twice the basic tolerances, but on a corner test at a particular load, the algebraic mean of the errors on the two corners at each end of the scale shall be not greater thin the basic tolerance for the load in question." The committee is of the opinion that practically all weights and measures officials are applying section rather than corner tests on rehicle scales and that, accordingly, this special shift-test tolerance is neither required nor used. It should be pointed out that this special tolerance does not apply to any class of scales other than vehicle scales. The committee recommends that tolerance paragraph 'T.2.1.2. TO SHIFT TESTS be amended to read as follows:

T.2.1.2. TO SHIFT TESTS.-Basic tolerances shall be applied.

(Item 5 of the Scale Code was adopted by roice rote.)

6. Tolerance paragraph T.2.3.4. FOR RAILWAT TRACK SCALES.- As indicated in the footnote on page 67 of Handbook 44 , the tolerances set forth for railway track scales, together with associated text, ale set forth in the form in which they have been published by the National Bureau of Standards. Paragraph B on page 69 reads: "The maintenance tolerance (applicable to scales in use) for scales in grain-weighing service is \pm 0.10 percent of the test load being utilized, applied as follows: . ." The committee has received a witten communication from Mr. A. S. Krefting, Chairman, American Railwa Engineering Association Committee No. 14. in which it is pointed out that Committee $1+$ will recommend to the IRE.I that this special tolerance for railway track scales in grainweighing service be deleted, thus making snch scales snbject to the basic tolerance of \pm 0.20 percent of the test load. Mr. Krefting las sngested that the National Conference similarly modify the language in tolerance paragraph T.2.3.t. FOR RAILTIY' TRACK SCALES.

The committee has not had an opportunity to explore this matter thoroughly, nor would it be disposed to make a recommendation to the Conference mutil it has been apprised of the final action of the IRE.L. The committee feels that this matter requires further study: therefore, it is proposed that this item be retained on the agenda of the committee.

7. Tolerances for Zarge-capacity scrles.-The Southern Weights and Measnes Association has recommended that the National Conference "review the tolerances for large-capacity scales." Durjng the interim meeting of this committee, the structure of tolerances for large-capacity scales was discussed at some length with representatives of the manufacturers of such scales. The scale mannfacturers and the Scule Mannfacturers Association have volnnteered to study this matter thoroughly and to be in further commmication with the committee. The committee, in the meantime, plans to conduct its own stndy. The committee desires to express its sincere appreciation to the Southern Weights and Measures Association for bringing this matter officially before the National Conference. 
S. Regulution puregraph li.t. YALUE OF MINIMLAL GRADLITED IN'TERTII.-

(a) R.t.1. ON RET.IIL FOOD SCII.S.-It has been pointed out to the committee that certain complications arise from the stipulation that "'The ralue of the minimum gratduated interval on a stale used for the retail sale of foodstuff's shall be not greater than 1 onnce." becanse the word "retail" is not defined. A specific example is the sale of meats in locker plants, where there frequently are individual retail sales of 50 to 100 pounds, and even more. Dial scales with at least 125-pound capacities have been used in this serrice. and to require such scales to hare 1-ounce graduated intervals and thus $1 / 8$-ounce minimum acceptance tolerances seems impractical. One suggestion being considered is that regulation paragraph R.t.1. be rewritten along the following lines:

R.4.1. ON RETAIL FOOD SCALES.-The ralue of the minimum graduated interval on a scale used for the retail sale of foodstuffs weighing 30 pounds or less shall be not greater than 1 ounce. (For retail sale of foodstufts weighing more than 30 pounds, see G-R.3.)

The reasoning behind this suggestion is that computing scales with 1-ounce gradultions are generally arailable up to 30 pounds capacity. and are not arailable at capacities of greater than 30 pounds.

The committee feels that this matter requires further study; therefore, it is proposed that this item be retained on the agenda of the committee.

(b) R.4.4. ON TEHICLE, THEEL-LOAD, AND A XLE-LOAD SC.MLES. - The Weights and Measures Division of the Ohio Department of Agriculture and the Scale Manufacturers Association have recommended to the committee that wheel-load and axle-load scales be removed from this paragraph, which requires a minimum graduated interval of 20 pounds, and that such scales then be permitted to be corered by regulation paragraph R.4.7., which requires minimum graduated intervals not greater than 0.1 percent of the nominal capacity of the scale or 50 pounds, whicherer is less. The committee understands that these recommendations were made principally to cover (1) wheel-load and axle-load scales considered to be noncommercial and tested only on request, and (2) wheel-load and axle-load scales that were considered to be commercial only because a charge was made for the weighing operation. Since the committee is recommending that the General Code and the Scale Corle be amencled to eliminate the latter, and since the first category is not included under weights and measures law, it is deemed by the committee that this would not be an appropriate change in the requirements.

The wheel-load and axle-load scales that will now be specifically corered by the code are those official scales that are used by law enforcement officers to enforce highway load-limit laws. Not a single request has been receired by the committee from such officials that this requirement be liberalized to permit 50-pound graduations on these scales. It must be concederl that. where enforcement of law is based on weighing, both accuracy and precision are critical. It is the judgment of the committee that any such liberalization in minimum gradnated intervals as has been suggested would umnecessarily 
detract from good reighing practice; accordingly, the committee recommends no action.

\section{DISCUSSION OF FOREGOING ITEM}

Mr. Sanders: During our presentation to the conmittee re stated that we had made a limited smrvey of the opinion of the State highway enforcement officers. Six of the seren States that responded to our questionnaire were in favor of a 50 -pound graduation on axleload scales. The have strongly recommended, and we do so now, that the Conference permit 50-pound graduations for these scales. The State highway departments are going to continne to purchase scales with 50-ponnd gradnations, and we think the National Conference should go along with this proposition.

Mr. KEndall: I rould like to take this opportunity to clarify the position of Toledo Scale with respect to item $8(\mathrm{~b})$ of the report regarding the maximum value of the minimum graduated interval on wheel-load and axle-load scales. Discussions with various weights and measures officials since the open meeting on Monday reveal there may be some misunderstanding.

1. Toledo Scale has no intention of proposing a cheaper grade of scale. We use this same scale with $10,000 \times 10$ pounds or even $5.000 \times 5$ pounds dial for industrial application, such as cupola charging or weighing heary ladles of molten metal, where a rugged lever system is required. 'Toledo has no problem meeting the required tolerances for the $20,000 \times 20$ pound dial with mit weights for the axle-load scale when tested with test weights.

2. Toledo has no direct interest. TVe do not operate any truck lines, so are not directly concemed with any delays in the weighing operation. You might say our interest should be in the opposite direction. because we would realize a greater sales volume with the appropriate $\$ 150$ or $\$ 200$ extra selling price for the unit weiglt scale.

TVe originally made the proposal with the idea of promoting the public interest. The primary consideration was the simpler, and less time-consuming weighing operation which would result. This additional selling price is but a small percentage of the installed cost of such a scale.

The basis for the proposal was that tests made by ourselves and other's show that, when the same axle of the same truck is repeatedly weighed on the same scale, weight indications will rary by as much as several hundred pounds. By inference, this condition is recognized in H-44, regulation R.19, which, effective July 1, 1957, prohibits adding the weight of individual axles to arrive at the commercial reight of a rehicle.

We still feel that specifying 20 pounds as the minimum graduation for a wheel- or axle-load scale is requiring a scale much more sensitive than is practical for this application, and a number of States feel the same way. Revising paragraphs R.4.4. and R.4.7. as suggested would permit those States which prefer 50-pound graduations to purchase such scales without taking exception to H-14. Any States which prefer 20-ponnd gradnations can specify them when purchasing. We muderstand California prefers 20 pounds because they frequently install both a vehicle and an axle scale and desire uniformity. New . Tersey also could specify 20 -pound gradua- 
tion, particularly when three axle-load scales are installed, but I would not want to express an opinion as to whether that combination constitutes a vehicle scale.

Tre are making these comments for information only, with no request for specific action by this Conference.

(Item S(b) of the Scale Code was adopted by roice rote.)

(c) R.4.7. ON LARGE-CAPACTTY SCALES OTHER THAN LIVESTOCK, ANIMAL, VEHICLE, TVHEEL-LOAD, AXLELOAD, HAND-OPERATED GRAIN HOPPER, CRANE, AND RAILTVAY TRACK SCALES.-The Scale Manufacturers Association renewed the recommendation submitted by it on April 14, 1960, with respect to the code requirements in the area of maximum value of minimum graduated interval on large-capacity scales covered in regulation paragraph R.4.7. That recommendation was in three parts: (1) that the nominal capacity (see definition paragraph D.1.) of an automatic-indicating scale be limited to the largest weight that can be indicated on the reading face; (2) that the maximum value of the minimum graduated interval on large-capacity, automaticindicating scales be not greater than 0.1 percent of the nominal capacity of the scale, or $1 / 4$ pound, whichever is greater, and in any case not greater than 50 pounds; and (3) that the maximum value of the minimum graduated interval on a weighbeam scale be not greater than 0.05 percent of the nominal capacity of the scale, or $1 / 4$ pound, whichever is greater, and in any case not greater than 50 pounds.

The Scale Manufacturers Association submits that these stipulations would require scales with smaller minimum graduated intervals than presently are required in regulation paragraph R.4.7., and further that scale manufacturers presently are offering devices that conform to this proposed requirement.

The committee has studied this matter for several years and is of the firm opinion that the Conference must continue diligently to aroid discrimination between two designs of similar equipment operating in the same field of commerce (for example, a weighbeamtype scale and a dial scale of relatively the same capacity). The present requirements are nondiscriminatory, entirely defensible, and enforceable.

It always has been the policy of the National Conference to specify only such requirements as are necessary to provide equity in commercial transactions for both buyers and sellers. The committee is conrinced that the present requirement provides this safeguard. Accordingly, the committee recommends no action.

9. Regulation paragraph R.9. APPROACHES TO VEHTCLE SCALES.-This paragraph provides that "At each end of a vehicle scale there should be a straight approach in the same plane as the platform for a distance equal to at least the length of the scale platform or 40 feet, whichever is less." It will be noted that this is a "should" paragraph, whereas practically all other paragraphs in the codes are "shall" paragraphs, as they properly should be, since, upon promulgation, they are given the force and effect of law. It has been and is conceded that in many cases, because of real estate limitations, terrain, and the like, it is not practical to provide straight 
and level approaches such as are recommended in regulation paragraph R.9.

With the adoption of regulation paragraph R.19. SINGLEDRAFT VEHICLE IVEIGHING. which prohibits multiple-draft weighing of highway rehicles, the significance of the approach to a rehicle scale was minimized; moreorer, confusion is introduced through the interpretation by manufacturer's' representatives, weights and measures officials, and other's that this is a mandatory requirement.

To eliminate confusion and to clear the code of a paragraph of doubtful value. the committee recommends that regulation paragraph R.9. be deleted.

(Item 9 of the Scale Code was adopted by roice rote.)

10. Installation and other recommendations.-In its report to the 45th Tational Conference, the committee noted that it was retaining on its agenda a suggestion of a State reights and measures official that there be included in Handbook $4 t$ certain recommendations concerning the installation of pit-type scales. The committee also noter that the Scale Manufacturers Association had agreed to study and make recommendation on this matter.

A specific recommendation has been receired from the Scale Manuacturers Issociation that takes the form of a rather lengthy series of requirements pertaining to the installation of rehicle and livestock scales. Ifter diligent study and thorough consideration, the committee now believes that it would be inappropriate to include provisions of this type in the Handbook $t+$ codes.

The Conference, in the development of its device codes, has attempted to aroid the inchusion of design and engineering specifications. and thus to limit the code, insofiar as practicable, to performance requirements. Design and engineering specifications have been included only when snch specifications were considered necessary to insure dependable and continued accuracy. The inclusion of design specifications with respect to pit constunction and installation would. it seems, be contrary to this principle.

It is obvious, and the committee emphasizes, that the installation of any weighing or measuring derice is vitally important with respect to performance of that derice. It follows that, if installation stipulations are to be set forth for one or two classes of devices, they likewise should be set forth for all other classes. The preparation of such material would be a major project, which would be highly complicated by widely rarving conditions and circumstances, in different locations, throughout the country.

The committee is sincerely alateful to the Scale Manufacturers Association for the obvious eflort that has gone into the submitted proposal. The committee nonetheless feels that installation recontmendations ale more nearly edncation than law and that they should be handled informally by lepresentatives of scale manufacturers. by weights and measures oflicials, and by others who are brought into a discussion conceming the installation of any comnercial weighing or measuring derice.

Is an alternative, the comnittee explored a plan whereby there was developed by the National Conference, through its Committee on 
Elncation, certain infornal Conference reconmendations on selection, installation, and maintenance of derices. 'The committee subnuited to the Committee on Edncation for its consideration as the first of snch formal recommendations, one pertaining to velicle scales. The Committee on Education submitted this first recomnumdation for action by the t6th National Conference on Weights and Measures on Wednesday, June 14.

\section{DISCUSSION OF FOREGOING ITEM}

Mr. S.xpers: 'The Scale Mannfacturers Issociation prepared certain formal recommendations with respect to this matter. We referred them to this committee, and we very strongly mige that the Conference consider in the future some sort of firm recommendations corering the installation of large-capacity scales. Te hope that this committee will consider adding such recommendations to Handbook $t 4$ to corer the installation of these scales.

11. Prepackaging scale.-The committee has been studiously and thoroughly exploring the prepackaging scale as a commercial weighing device. When the Scale Code was first amended to include special provisions for such scales, some doubts were expressed by experienced officials as to the appropriateness of such action. It was pointed out then that the true role of the prepackaging scale in commerce is that of a tool or accessory in the process of preparing packaged food; and since there are very special provisions in weights and measures law regarding the accuracy of the quantity declaration on packiges, the propriety and appropriateness of "sealing" prepackaging scales were questioned.

Two points seem to be at issue. First, the packaging equipment used in the determination of the quantities of the thousands of different factory-packed items has not. as a rule, been controlled by the weights and measures official. Here there is permitted (or required) to prevail the philosophy "the package speaks for itself." Just how the quantity is determined in such instances is considered to be of no official consequence, so long as the law has established specific control orer such quantity. (It is an interesting fact that many factory-packed packages are filled volumetrically, even though the quantity of the contents of such packages is declared in terms of net weight.) It is probable that the establishment of oflicial control orer the prepackaging scale was the result of the physical movement of the computing scale from the meat counter of the service-type market to the back room of the prepack market. The official control simply followed this movement.

The second point has to do with the relationship of scale approval to official action on packages. The contention has been made that an inconsistency is established when the official approves, under law, the use of a prepackaging scale that is within the legally established tolerances, yet has an error of over-registration, and then disapproves packages carefully weighed over the scale when the net quantity of the contents of these packages averages less than the quantity declared, this latter action being entirely in accord with the provisions of the "package" law.

The problem grows as prepackaging increases. 
The committee is not yet prepared to submit a definite recommendation with respect to prepackaging scales. In its deliberations, the committee would find most helpful constructive comments from qualified weights and measures officials and from others having an interest in this matter.

A possible approach might be to follow, in the case of prepackaging scales, the quoted principle "The package speaks for itself" by removing from the Scale Code all references to prepackaging scales and by considering the Model Law as to its coverage of such devices.

\section{LIQUID-MEASURING DEVICE CODE}

1. Retum to zero.-The committee received from the Southern Weights and Measures Association a recommendation that was endorsed by the Gasoline Pump Manufacturers Association, the effect of which would be to amend the Code for Liquid-Measuring Devices to permit on retail liquid-fuel dispensers (gasoline pumps) recording elements that are cumulative in nature - that is, recording elements that would not return to zero before each delivery, but rather would print a totalized figure representing gallons at the start of a delivery and another totalized figure representing the gallons at the end of the delivery. After a study of this recommendation, the committee has concluded that, while such a change in the code might serve as a convenience to some users of retail liquid-fuel devices, it definitely would be a distinct loss to consumer's.

Since mechanical devices for measuring liquid fuels for automobiles were first placed into service, weights and measures officials have insisted that there be means by which such devices could be returned to zero prior to each delivery, and that the indicating or recording elements be so returned. Progress in the design of such devices, the expiration of patents, and consumer interests have brought about the present non retroactive requirement that provides specifically that a retail liquid-fuel device must be equipped with a "zero-setback interlock" (see S.11.1 of the Tiquid Measuring Device Code) and thus be returned to zero prior to each delivery. On this point the committee feels quite strongly that the Conference must stand firm; accordingly, the committee recommends no action.

\section{DISCUSSION OF FOREGOING ITEM}

Mr. G. T. Wrignt: In the tentative report the reasons given for the committee recommendation of no action are based upon the assumption that the recommendation had to do with the elimination of the present requirements for primary indicating elements. The code is very clear in differentiating between indicating and recording elements, and, in the recommendation of the Southern Weights and Measures Association, upon which the Gasoline Pump Manufactulers Association based its endorsement, there was no reference whatsoever to any change in the requirements for primary indicating elements. The committee notes that, since mechanical derices for measuring liquids first were placed in service, weights and measures officials have insisted that there be means by which the indicating elements of such devices could be returned to zero after each delivery and that the indicating or recording elements be so returned. Howerer, as a matter of fact, there is no mention in the Liquid-Measuring Device 
Code of the return of recording elements to zero. I make that point because I feel that the committee may have misinterpreted the origilial proposil.

There are two types of retail fuel dispensers for large deliveries to trucks, and each of these types sonletimes is equipped with an a uxiliary ticket-printing derice. These ticket printers are not in any way a substitute for, nor do they eliminate, the necessity of the primary indicating element to which is connected the zero-set-back interlock. Wre never have suggested any change in the requirements corering indicating elements.

Since it appears that the committee's recommendation is based on a misinterpretation, I strongly urge that the committee either rescind its recommendation or retain this item on its a genda for action next vear. Wre feel that our suggestion has considerable merit, and we feel further that our suggestion was not considered by the committee, whose decision was based on something we did not suggest.

(at this point Mr. J. T. Kennedy spoke in opposition to the committee recommendation and. on his motion, seconded from the floor, the Conference directed by roice rote that this item be retained by the committee for further study.)

2. Specification paragraph S.11.3. VISIBILITY.-The Gasoline Pump Manufacturers Association made an urgent plea to the committee for relief from the requirements stipulated in specification paragraph S.11.3. that "The bottom of the lowest indicating element of a retail motor-fuel device shall be at least 36 inches above the normal lerel upon which the receiving vehicle or vessel stands. The indications of a retail motor-fuel device shall be readable from any position within a field of $120^{\circ}$, defined by two vertical planes each passing through the center of the face of the device at an angle of $30^{\circ}$ ". The industry submitted that engineering advances in the design of retail gasoline dispensers were being restricted by this special requirement relating to visibility. No specific example was pointed out, however, where such restriction had occurred in the past, or was occurring at the present. 'The further contention was made that these special requirements are not necessary for the proper protection of the consumer. Industry representatives also pointed out that, with respect to all other weighing and measuring devices used in retail trade, officials were relying on the language of General Code regulation paragraph G-R.1. POSITION OF EQUIPMENT.

In the industry's brief, the recommendation included an amendment to specification paragraph S.3.1. READABILITY according to the words that are in italics: "Quantity and money-value indications shall be readable from any reasonable customer position within the limits of the device." It was pointed out to representatives of the industry that the language of specification paragraph S.3.1. as it now stands is almost identical with and certainly would be interpreted the same as the language in general regulation paragraph G-R.1., and that the suggested addition would weaken the requirement and introduce confusion in interpretation.

The special requirements contained in specification paragraph S.11.3. are of many years' standing. They were inserted originally because of the special problems of risibility brought about by the fact that the retail purchaser of gasoline is usually seated in his car when the purchase is made. While the committee feels that this 
industry recommendation deserves careful study and consideration, it feels also that this study should extend to all weights and measures officials and other's who are interested. The manufacturer's of retail gasoline dispensers hare presented no specific evidence or examples that would require specification paragraph S.11.3. to be modified or deleted. Pending such demonstrated need, the committee recommends no change in the code at this time.

\section{DISCUSSION OF FOREGOIYG ITEM}

Mr. G. T. Wright: The committee states that the manufacturer's of retail gasoline dispensers have presented no specific eridence or examples that would require the modification or deletion of specification paragraph S.11.3. This is correct and is of importance to us. It presents the view that a manufacturer would be required to invest design, engineering, and fabrication costs in a device that might not meet code requirements and then submit the derice to the committee in the hope that conflicting requirements would be reconciled. Tre contend that a manufactnler should be able to explore the merits of a requirement and receive such relief as would clear the way for new design. Te contend the 36 -inch height requirement of this specification is arbitrary. It was based on a condition that existed many yeal's ago and that no longer exists. We should hope that the industry would be free to manufacture devices and locate them anywhere as long as General Code requirements on risibility or retail derices are met.

(MIr. Anderson, Mr. Christie, and Mr. J. T. Kennedy also spoke in opposition to the committee recommendation.)

(Mr. Kemnedy moved that the first sentence of specification paragraph S.11.3. be deleted. This motion was seconded fron the floor, and Mr. Leithauser and Mr: W. C. Hughes spoke in faror of the amendment. Mr. Harris spoke against the amendment. On motion of Mr. F. F. Thompson, seconded from the $110 \mathrm{or}$, this item of the committee report was laid on the table for one vear by roice rote of the Conference.)

3. During the open hearing on Monday afternoon there was presented for the consideration of the committee, by $\mathrm{Mr}$. Greene of Connecticut, a type of construction of certain remote-pumping gasoline dispenser's such that the hose nozzle can ostensibly be linng ip in normal manner but without actuating the set-back interlock. Thus a particular delivery may be begun without resetting the indicating elements to zero.' 'The committee, after exploring various methods of meeting this situation, is convinced that the problem can adequately be met by rigorous enforcement under G-S.2. FACILITATION OF FRAUD and G-R.5. METHOD OF OPERATION, and that this approach is to be preferred to the drafting of new specification language.

(Item 3 of the Liquid-Measmring Device Code was adopted by voice vote.)

\section{VEHICLE TANK GODE}

1. Specification paragraph S.10.10. MIXNIFOLD.-The Southern Weights and Measures Association recommended that the National Conference amend specification paragraph S.10.10. to specifically permit "bot tom loading." The committee is of the opinion that nothing in the General Code or in the Vehicle Tank Code prohibits bottom 
loading so long as of her code requirements are complied with. It is a general logal principle that what is not prohibited is permitted: therefore, the committee sees no adrantage in making special mention of this method. Areordingly, the committee recommends no action.

(Item 1 of the Vehicle lank Code was adopted by voice vote.)

2. Specification parugraph \$.10.1. COMPARTMENT DISTORII()N.- Just prior to the t5th Nitional Conference on Weights and Mcasmres, the National Truck Tank and Trailer 'Tank Institute, supported hy the National Tank Truck Carriers. Inc., requested that the committee reconsider the requirements set forth in the then specification paragraph S.1. (now S.10.1) that the bulkhead distortion of a rehicle-tank compartment (caused by the filling of the compartment or" compartments adjoining) be limited to $1 / 2$ pint per $200 \mathrm{gallons}$ or fraction thereof, or 1 pint, whichever is greater.

'The committee considered this matter prior to the 45 th Conference and recommended sereral amendments, the principal of which was to nove the questioned requirements to the sections of the code applicable only to rehicle tanks used as measures. (See item 10, page 98, IBS IIiscellaneous Publication 235, Report of the 45th National Conference on Treights and Measures, 1960.) 'The committee did not feel justified in recommending to the Conference for adoption, based on the information and evidence presented, the rather liberal modification of the distortion requirement. 'The National 'Truck Tank and Trailer Tank Institute has renewed its request and recommendation of th is amendment, and the committee since has been attempting to get all possible information on this request, including an official expression of opinion from the North American Gasoline Tax Conference. an organization of State tax officials. many of whom a re concerned with the accuracy of rehicle-tank compartments when these are used to measmre petrolem products for tax purposes, the American Petroleum Institute Committee on Weights and Measures, weights and measmres officials, and others. The study of the North American Gasoline Tax Conference has not yet been completed. 'The Committee on Specifications and Tolerances also has certain other matters in this area to be explored.

The recommendation of the National Truck Tank and Trailer Tank Institute is that the distortion formula in specification paragraph S.10.1. be amended to allow "a tolerance of .4 of 1 percent of the net rehicle-tank or tank-compartment capacity, expressed in gallons up to 625 gallons, and tolerance of vehicle tank or tank compartments of capacities 625 gallons and up limited to maximum of 2.5 gallons."

Neither an exhaustive study by the committee nor a survey by the North American Gasoline 'Tax Conference has disclosed evidence of any hardship resulting from specification paragraph S.10.1. Accordingly, the committee recommends no action.

(Item 2 of the Vehicle Tank Code was adopted by voice vote.)

FARM MILK TANK CODE

Tolerances. - The committee's final report to the 45th National Conference indicated the retention on its agenda of the matter relat- 
ing to a recommendation from a State weights and measures official that the tolerances on farm milk tanks in the smaller sizes be reduced. During the year the committee has been in consultation with the National Association of Dairy Equipment Manufacturers, the Dairy Industry Supply Association, and other weights and measures officials, and now recommends the following amendments to the Farm Milk Tank Code, amendments that have the endorsement of both organizations listed here.

Amend specification paragraphs S.3. SENSITIVENESS and S.4. GALLONAGE CHART. and TABLE 1 of tolerance paragraph T.2. BASTC TOLERANCE VALUES, to read as follows:

S.3. SENSITIVENESS.-The ralue of a graduated interval on a gage rod or surface gage (exclusive of the interval from the bottom of the tank to the lowest graduation) shall not exceed (a) $1 / 2$ gallon for a tank having a nominal capacity of 250 gallons or less, (b) 1 gallon for a tank of a nominal capacity of 251 to 500 gallons, inclusive, and (c) 2 gallons for a tank of a nominal capacity of more than 500 gallons.

S.4. GALLONAGE CHART.-A gallonage chart shall show gallonage values only, and shall show such values at least to the nearest $1 / 4$ gallon for a tank of a nominal capacity of 250 gallons or less. at least to the nearest $1 / 2$ gallon for a tank of a nominal capacity of 251 to 500 gallons, inclusive, and at least to the nearest 1 allon for a tank of a nominal calnacity of nole than 500 gallons. All letters and figures on the chart shall be distinct and easily readable, the chart shall be substantially constructed, and the face of the chart shall be so protected that its lettering and figures will not tend easily to become obliterated or illegible.

TABLE 1. Basic maintenancc and acceptance tolerances, on underregistration and on overrcgistration for farm milk tanks

\begin{tabular}{|c|c|}
\hline Indicated gallonage & Tolerance \\
\hline $\begin{array}{l}250 \text { or } \text { less } \\
251 \text { to } 500 \text {, inclusive } \\
501 \text { to } 1,000 \text {, inclusive } \\
1,001 \text { to } 1,500 \text {, inclusive } \\
1,501 \text { to } 2,000 \text {, inclusive } \\
\text { Over } 2,000\end{array}$ & $\begin{array}{c}\text { Gallons } \\
1 / 2 \\
1 \\
2 \\
3 \\
4 \\
5\end{array}$ \\
\hline
\end{tabular}

(The amendments to the Farm Milk Tank Code were adopted by voice rote.)

\section{PAINT CONTAINERS}

From the Southern Weights and Measures Issociation has come the recommendation "That a standard fill-point be established for paint in containers for nominal sizes of the gallon and binary submultiples thereof, and providing for reasonable expansion space in same." With respect to this recommendation, the committee points out that the container's used in the paint industry are not "measure containers" but are merely carrying containers similar to paper cartons for milk, cans for vegetables, and wrappers for prepackaged meat prodncts. Paint in containers must be considered as packages and thus are subject to the provisions of the Model Law that relate to packages and to the Model Package Regulations. Since paint 
containers are not measure containers, they do not come within the jurisdiction of the Specifications and Tolerances Committee. $\mathrm{\Lambda c}$ cordingly, the committee recommends no action.

(This item was adopted by voice vote.)

The Specifications and Tolerances Committee desires to record formally its appreciation to all who have participated in its deliberations, either in writing or in person during the interim meeting. The committee can fulfill its responsibility only with full cooperation from weights and measures officials and business and commercial interests.
C. L. JACKSon, Chairman
A. H. DitTriciI
T. C. Harris, Jr.
R. W. Searles
D. M. TURNBULL
IV. S. Bussex, Secretary

(On motion of the committee chairman, seconded from the floor, the Conference by roice vote authorized the National Bureau of Standards to make any appropriate editorial changes in the language adopted by the Conference, so long as the principles thus adopted are strictly adhered to.)

(On motion of the committee chairman, seconded from the floor, the Conference by voice vote adopted the report of the Committee on Specifications and Tolerances, comprising the tentative report as amended by the final report and as amended from the floor.)

\title{
FIFTH SESSION-MORNING OF FRIDAY, JUNE 16, 1961
}

(R. E. Meek, Chatrman, Prestding.)

\section{REPORT OF THE AUDITING COMMITTEE}

Presented by C. W. Vax Schork, Chairman, Chief, Division of Weights and Measures, Department of Agriculture, State of Ohio

On behalf of the Auditing Committee, I deem it a pleasure to report evidence of a job well done. I want to commend the Treasurer for the condition of his books and the ease with which they mere audited. So in behalf of the Auditing Committee, I move that the report of the Auditing Committee be accepted.

\author{
C. W. VAN SCHoIK, Chairman \\ W. E. Czaia \\ W. I. Thompson
}

(On motion of the committee chairman, seconded from the floor, the report of the Auditing Committee was adopted by the Conference.) 


\section{REPORT OF THE TREASURER}

Presented by C. C. Morgan, Treasurer, City Sealer of Weights and Measures, Gary, Indiana

Balance on hand June 1, 1960

$\$ 2,639.35$

RECEIPTS:

Registration fees -1960 Conference, 313 at $\$ 10$

$\$ 3,130.00$

Bank interest accrued

105. 44

Miscellaneous

23. 47

Subtotal

$\$ 3,258.91$

Total

DisBuRSEMENTS:

Expenses of 45th National Conference:

Hotel expenses for Conference party (Sheraton Hall, reception and dance, refreshments, and waiters) and other miscellaneous hotel and Conference expenses . . . . . . .

Music (Sabin Productions) for Conference party .........................

Ladies' entertainment:

Blair Mansion $\ldots \ldots \ldots$

Ladies' Fashion Show, Phyllis Boddies... AB\& IV Transit Co

Bus transportation of delegates to Department of Commerce.................

Other Conference expenses:

Flowers, Sheraton-Park Hotel _........

C. \& P. Teleplione Company

Expenses of Conference subsequent to June 10 , 1960:

National Weights and Measures Week:

G. II. Allen Co. for letterheads_........

American Electrotype Co. for mats . . . -

C. H. Stender

32. 59

76. 50

52. 30

J. E. Bowen, postage _....... 3. 45

Travel expenses for interim meetings:

Committee on Laws and Regulations

Committee on Specifications and Tolerances_........................

Attendance Certificates, R. D. Ewin Flowers:

Blackistone, Ine., for Mr. A. J. Mayer --

Sheraton-Cast Hotel, for Mr. and Mrs. J. R. Roberts

754. 10

978. 07

13. 60

9. 72

10. 30

Postage stamps:

R. E. Meck, Chairman, 46th Conference _...

II. S. Bussey, Secretary

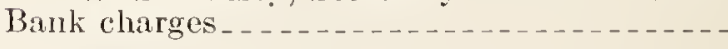

4. 00

6. 00

5. 40

Subtotal

$\$ 3,783.13$

$3,783.13$

$\$ 2,115.13$

Total balance on hand June 1, 1961

3, 258. 91

$\$ 5,898.26$

50. 00

160. 20

160. 00

5. 24

2. 95

\section{DEPOSITORY:}

Gary Trust and Savings Bank, Gary, Indiana.

First Federal Savings and Loan Association, Gary, Indiana.

(Signed) C. C. Morgan,

Treasurer

(On motion of the Treasurer, seconded from the floor, the report of the Treasurer was adopted by the Conference.) 
()n Friday morning, June 16, the newly elected Executive Committee, the chilimen of the standing committees, and the weights and nusures members of the Arrisory Committee were invited to neet 10 study and reach decisions regarding the 47th Conference. 'The mereting was presided over by the newly elected Conference Chairnum, Robert Williams of Nassan Comnty, New York. The following decisions were reached regarding the 47 th National Conference on Weights and Measures, 1962 :

1. Place: Sheraton-I'ark Hotel, Washington, D.C.

2. Date: Jume 4-S, 1962 .

3. Duration: Opell committee meetings on Monday all day and on Tueslay molning. Opening session Tuesday afternoon. Wednesday afternoon tree of any scheduled business sessions. Business sessions Thurstay and Fiday accolding to proglam plans.

4. Official Conference Luncheon: To be held again in 1962.

5. Ladies' Entertaimment: Left to the discretion of the Executive Serretaly and the Ladies' Committee.

6. (Mr. Robert Williams of Nassau County, New Jork, the newly elected ('onference Cliairman, reported as follows:)

Among the decisions made was one to record for action next year a proposed amendment to the Conference Organization and Procedure. This amendment is designed to inclnde in the membership of the Executive Committee in a nonvoting status all past chaimen who are still active as regnlatory weights and measmres officials. Accordingly, Mr. Chairman, I wish to place on the record the following proposed amendment to Section 5 of the Organization and Procednre, which is entitled Committees:

In line 6 of the first paragraph, following the comma, amend to read: "and an Executive Committee consisting of all the officers, $c x$ officio, past. rhairmen of the Conference still active as regulatory weights and measures officials, and ten members elected from the active membership. Provided, That the Executive Secretary and the past chairmen shall not have rotes on mattel's before the Erecutive Committee."

This is for a matter of recording this year to be roted on next year.

\section{REPORT OF THE COMMITEE ON LAWS AND REGULATIONS}

\section{Presented by Robent Wrumans, Chaiman, County Seater of Weights and Measures, Nassau County, New York}

The Committee on Laws and Regnlations of the 46th National Conference on Weights and Measmres submits its report-a tentative report as amended by the final report. The committee is orateful for the many constructive suggestions received by mail, during its interim meeting in February and during its open meeting on Monday, June 12. ['The report as presented here comprises the two reports, tentative and final, combined.]

\section{National Pattern (type) Approval.}

Prior to the 45th National Conference on Weights and Measures, the Sonthern Weights and Measures Association referred to the committee for study the subject of national pattern approval of commercial weighing and measuring devices. This being a broad and definitely an important topic, the committee continued it on its 
agenda for further study. The committee proposed to direct its study along two basic lines: (1) the derelopment of suitable Federal legislation to establish a national system of pattern approval applicable throughout the country and $(2)$ the extension of the plan of State pattern approral to all States not presently having adequate legislation for this purpose. 'The committee has pursned this study.

During the discussion of this topic on the floor of the 45 th $\mathrm{Na}$ tional Conference, a rather fundamental question was raised by a representative of the Gasoline Pump Manufacturers Association. That question was: "Is type [pattern] approval itself a good thing?" In order that the committee might have the benefit of the thinking of competent weights and measmres officials in this regard, the contmittee chairman, mnder date of October 5, 1960, directed the following questions to more than 125 State, connty, and city weights and measures officials located in all 50 States, the District of Columbia, and Puerto Rico.

In your opinion, is State or National type [pattern] approval prior to sale of commercial weighing and measuring devices advisable?

In your opinion, would State or National type [pattern] approval facilitate your enforcement program?

Out of 58 replies to these two questions, 57 replies to both questions were in the affirmative. Only one official who responded expressed the opinion that neitler State nor National pattern approval was advisable and that it would not facilitate lis enforcement program.

'The following question was also asked in the letter of October 5:

Which, in your opinion, would be most effective and appropriate, State or National type [pattern] approval?

Twenty-eight State officials replied to this question, 22 of whom expressed a preference for National pattern approral, and 6 farored State pattern approval. Of the 6 faroring State pattern approval, 4 presently have State laws or regulations providing for State pattern approval in their jurisdictions.

Twenty-eight local officials from 12 different States answered this question. Eleren officials from $S$ different States expressed a preference in faror of National pattern apploval. Sixteen officials from 6 States expressed a preference for State pattern approval. One oflicial firored both National and State pattern approral. Three of the 6 States represented in this aroup have laws or regulations providing for State pattern approval, and 11 of the 16 replies came from these 3 States.

The committee is convinced that it is the overwhelming consensus of the weights and measures oflicials throughout the United States that pattern approval is "a good thing" and that it does facilitate the implementation of an enforcement program. This same opinion also exists in most other countries of the world supporting comprehensive weights and measmes enforcement, programs, according to available information. Based on this conchnsion, the principal question left manswered is: Which is the more desirable, (1) Nafiomal or (2) State pattern approval? From the expression of a sizable majority of the weights and measmres officials responding to the commitiee's letter, National pattern approval would be preferred.

During the interim meeting of the committee in .Tannary, rather 
strong and forceful opposition to both State and National pattern approval was offered by the Scale Manufacturers Issociation. Althongh the ofticial position of the Gasoline Pump Mannfacturers Association was not identical with that of the Scale Manufacturers Association, the Gasoline Pump Manufacturers Association did not indicate any faror for National pattern approval. 'The committee is convinced that it can be safely assumed that a large majority of the manufacturers of weighing and measuring derices are opposed to National pattern approval.

Based on its study, including the open discussions at its interim meeting in January, the committee would summarize as follows:

(a) Pattern approral of commercial weighing and measuring devices prior to sale is desirable and is beneficial to a weights and measules enforcement plogram.

(b) Nearly all weights and measures officials in the United States favol. some form of pattern approval.

(c) A sizable majority of weights and measures officials in the United States (State, county, and city) consider National pattern approval to be preferable to State pattern approval.

(d) A sizable majority of lepresentatives of manufacturel's of commercial weighing and measuring devices oppose National pattern approval, and the Scale Manufacturers Association has also gone on record as opposing State pattern approval.

(e) Representatives of users of commercial weighing and measuring devices and representatives of consumer groups have not been contacted by the committee.

(f) Some form of "central" patteln approral wherein the technical examinations would be performed in a properly equipped laboratory by qualified and unbiased technicians, either gorernmental or private, at the specific request of State officials under State law, and not under a mandatory Federal law, would appear to be less objectionable to manufacturer's' lepresentatives than would outright National pattern approval.

(g) It is generally conceded that no State now exercising patteln approval has adequate laboratory and shop facilities and sufficient technically trained personnel to carry on a State pattern approval program properly and effectively.

(h) Numerous instances are known where State patteln approval has been granted even though the device failed to comply with all requirements of the H44 codes and with the regulations officially and legally adopted by the State.

(i) It is conceded that the Model State Law on Weights and Measures in its plesent form, and most State laws now in effect, provide ample authority to a State to establish State pattern approval and that no further amendments are necessary to provide such authority.

(j) If all 50 States, the District of Colmmbia, and Puelto Rico were to individually establish their own patteln approval operations, the resulting situation would be most unsatisfactory.

(k) The committee is convinced that some form of central pattern approval is not only desirable, but greatly needed.

(1) The committee does not feel that thele is sufficient knowledge of and interest in this subject, at the present time, on the part of weights and measures officials, manufacturers' representatives, device users, and the general public to assure the success of Fedelal legislation establishing mandatory Tational pattern approval.

(m) The committee does feel that this subject is of such importance to the future of weights and measures administration in this country that weights and measures officials and others should continue to give it their attention and study, and should continue to discuss and explain its merits to all persons having an interest in efficient and effective weights and measures administration.

The committee concludes that, if at any future time a person or group of persons feels that the National Confele- ce should give further formal attention to and study of the pollem, such fact 
should be brought to the attention of the officers and appropriate committee or committees of the Conference. In the meantime, if any State is interested in establishing pattern approval at the State level, this should be undertaken by the adoption of a proper State regulation, or by legislative action if the latter is deemed necessary.

With the adoption of this report by the Conference, the committee proposes to remove this subject from its agenda.

Mr. STENDER: The principles of type approval have been on our program for the last two years because of action in the Southern Association back in 1959. I had the privilege of delivering a paper on this subject last year. I have had nothing presented to me in either written form or letter form, nor have I heard any statement that has been made that makes me feel that national type approval should be placed away in the files forever. With all the equipment that we are getting today, we are doing too much testing in the field, testing that the consumer pays for. I hope that the National Conference will give this matter further study, and I firmly believe that national type approval would prove to be an advantage to industry instead of the detriment it now thinks it would be.

(On motion of the committee chairman, seconded from the floor, item 1 was adopted by the Conference by voice vote)

\section{Methods of Sale of Commodities}

'The committee has studied various ways and means of effectuating its recommendations as adopted by the Conference in the area of methods of sale of commodities. Over a considerable number of years, the Conference has adopted stipulations and recommendations as to how individual commodities should be sold. Certain of these recommendations have conflicted with others, and some definitely cannot be hammonized with the most recent Model Law and Model Package Regulation.

It now appears to the committee that its mission in this particular area should not be one of bringing forth firm recommendations, but rather should be one of determining whether a merchandising situation is of special character and, if so, developing either a Model Law anendment, a Nodel Regulation amendment, a special law or regulation, or an ofticial interpretation of existing law or regulation.

The committee has reviewed the multitude of recommendations as to methods of sale that liave been adopted by the Conference in the past and is of the opinion that, with few exceptions, all commodities previously acted upon are either appropriately covered in current Model Taws and Regulations or the recommendations are obsolete. Accordingly, the conmittee recommends that all previous actions be rescinded and offers for Conference consideration the items in this report.

In the future, the committee will analyze particular commodities brought to its attention to determine the advisability of Conference action. It appears that, if the past is typical, many requests for inferpretation are local in character or are clearly covered in the Model Taw or Regulation. These will be answered by direet correspondence.

Conmodities that, because of their very special character, are deened of sufticient importance for Conference action will be studied very carefully prior to any recommentation to the Conference. 
The committe recommends the adoption of the following two regulations as models for State action.

\section{MODEL, REGLLTTOX FOR P'APR P'RODUG'S}

l'irsinant to the autlority vested in me as set forth in sertion (forctions anc 2.5 of the Moclel law) of chapter

statutes of the State of ------------------ [cite sections authn
mulsation of remeral regulation and special commodity sections], I, of the

State Director of Weights and Measures, hereby arlopt ancl promulgate the following regulation:

1. Paper Tapkins and l'aper Towels.-The declaration of quantity on a fackage of paper napkins or paper towels shall indicate the numerical count and the dimensions of the individual napkins ol towels contained in the packnge.

2. Writing Paper, Notebook Paper, Envelopes.-The declaration of quantity on a package of writing paper, notebook paper, or envelopes shall indicate the number of sheets or envelopes, as the case may be, in the package. When envelopes are included in a package of writing paper, the declaration shall indicate both the number of sheets of paper and the number of envelopes.

3. Tablets and Books of Writing Paper.-The declaration of quantity on a package of tablets or books of writing paper shall indicate the number of tablets or books in the package.

4. Wrapping Paper.-The declaration of quantity on a package of wrapvinc paper in sheet form mar be in terms of either numerical count or of net weight. If the declaration is in terms of numerical count, it shall indicate both the dimensions of an individual sheet and the number of sheets in the package.

5. Fucial Tissues.-The declaration of quantity on a package of facial tissues shall indicate the numerical count of usable units (a sheet of two or three ply shall be considered a single usable unit) and the dimensions of the inclividual unit.

6. Toilet Tissues.-The declaration of quantity on a package of toilet tissues in roll or sheet form shall indicate the numerical count of usable units (a sheet of two or three ply sliall be considered a single usable unit) and the dimensions of the individual unit.

7. Supplementary Quantity Deelarations.-Any declaration or statement relating to the quantity of contents of a package of paper product that is in ardition to or supplementary to the declaration required by law or regulatinn shall be in juxtaposition with and shall be subordinated to the required leclaration.

8. Exemption.-Rolls or packages of paper products for industrial use only and not for resale need not be marked individually so long as the container in which such rolls or packages are packed is properly marked to show the quantity of the cuntents of such container.

9. This regulation is additive to valid laws and other regulations pertaining to packages and shall not be construed as superseding any such law or regulation.

\section{MODEL REgULATION FOR ROOFING AND ROOFING MATERIALS}

Pursuant to the authority vested in me as set forth in section (Sections :) and 25 of the Model Law) of chapter of the

statutes of the State of [cite sections authorizing promulgation of general regulation and special commodity sections], I,

State Director of Weights and Measures, hereby adopt and promulgate the following legulation :

1. Roofing and roofing materials shall be sold either by the "square" or" by" the "square foot." The term "square" shall mean the quantity of roofing or rnofing material that, when applied according to directions or instructions of the manufacturer, will cover an area of 100 square feet exclusive of side laps or side joints: Provided, That, in the case of roofing or roofing material of corrugated design, the side lap or side joint shall be one full corrugation.

'The ter.m "square foot" shall mean the quantity of roofing or roofing material that, when applied according to the directions or instructions of the 
manufacturer, will cover 1 square foot (144 square inches) exclusive of side laps ol side joints.

2. This regulation is adrlitive to valid laws and other regulations pertaining to packages and shall not be construed as superseding any such law or regulation.

(Item 2 was adopted by voice vote.)

\section{Standardization of Package Sizes}

At the suggestion of the Conference Chairman, the committee has been giving attention to the important matter of standardization of package sizes. This is an area that has received the attention of the National Conference iu the past and that presently is of serions concern to consumer organizations. There are a number of commodities that presently are offered in more or less standard size consumer packages (flour, butter, paint, distilled spirits, for example), but there are literally thousands of commodities packed in many and odd sizes.

The control of package sizes, through either voluntary agreement or legislative action, is a vely large undertaking, but its importance seems great enough to warrant Conference action at this time-at least with the beginning of what surely will be a long term project. Accordingly, a subcommittee of the Committee on Laws and Regullations has been established as follows: Marry M. Turrell, Director, Pennsylvania Bureau of Standard Weights and Measures, chairman; .Tohn G. Gustafson, Chief Inspector, Mimneapolis Department of Licenses, Weights, and Measures; and George L. Johnson, Director, Kentucky Division of Weights and Measures.

This entire matter should become a nujor topic of discussion among weights and measmres officials, packer's, wholesalers, retailers, and consumers. The subcommittee solicits comments and suggestions. Correspondence shonld be directed to the Conference Secretary, who will serve as secretary to the subcommittee.

(Item 3 was adopted hy voice vote.)

\section{Model State Lan}

Representatives of the Tissne Association, Inc, made a written request to the committee, which was supported by oral testimony at the committee's interim meeting, that the committee consider a proposed amendment to Section 29 of the Model Law. The reason given for the proposed amendment was that members of the 'Tissue Association believed the present wording of Section 2 ? of the Model Law could and possibly would be interpreted to require an exact duplication of the quantity statement on the label in the advertisement. It was the feeling of the committee that snch exact duplication was not intended. Therefore, the committee was impressed with the merits of the suggestion and now recommends for consideration and adoption the following: 'That Section 29 of the Model Law be amended to read as follows:

SEC. 29. SAME: ADVHRTISING PACKACHS FOR SALE.-Whenever a commodity in package form is advertisel in any nammer and the retail price of the package is stated in the arbetisement, there shall be closely and conspicuously associated with such statrment of price a reclaration of the basic quantity of contents of the package as is required by law or regulation to apperir on the package.

(ltem 4 was adopted by voice vote.) 


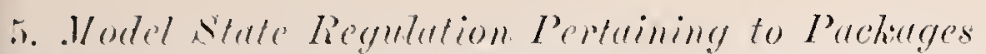

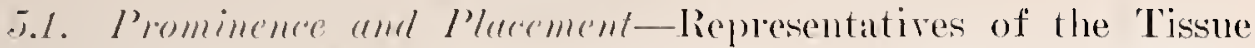
Issociation, Inc., made a sinilat request for an amendment of Section (; of the Model vitate Regulation Pertaining to Packages. It was subuitted that the prescnt wording of this section could logically be construed to require a quantity statement on as many as five panels of cartons containiug certain paper products. Similar situations would be encomtered in other commodities. Being impressed with the merits of this sugrestion, the committee offers for consideration and adoption the following: Anend Section 6 of the Model State Regulation Pertaining to Packages to read as follows:

6. PROMINENCE AND PLACEMENT.-All information required to appear on a package shall be plominent, definite, and plain, and shall be conspicuous is to size and style of letters and numbers and as to color of letters ind numbers in contrist to color of background. Such information shall appear on the principal display panel of the package. Any required information that is eitler in hand lettering or hand script shall be entirely clear and equal to printing in legibility.

5.2. Aerosol Containers-At the time the committee made its final leport to the t5th National Conference on Weights and Measures, Mr. H. F. Peterson, President, Peterson Filling and Packing Company, Danville, Illinois, represent ing the Chemical Specialties Manuficturers Association, had not delivered his rery comprehensive paper on this subject. Therefore, no final recommendation was made by the committee in this area. During the months which have ensued, the committee members and persommel of the National Burean of Standards have continued to study this problem, giving particular attention to Mr. Peter'son's papel.

'The conclusion reached from Mr. Peterson's paper is that all commodities packaged in aerosol containers should be labeled and sold by net weight. Mr. Peterson explained why sale by weight is ronsidered to be the only known method that is practical and can be used successfully in both the filling of the containers by the packer and the checking of the quantity of contents by the weights and measures official. It is readily acknowledged that this will mean, in many instances, that a specific product will be sold by "weight" in an aerosol container and universally sold by "liquid measmre" in conventional containers. (A specific example is paint.)

While the committee does not particularly like the idea of a given commodity being sold by liquid measure in one type of container and by weight in another type container, the committee does feel that the Conference must be both realistic and objective in its approach to any problem. In this particular instance, it is the opinion of the committee that sale by weight is the only practical method that can be utilized for products in aerosol containers. It is, therefore, the recommendation of the committee that all commodities packaged in aerosol containers should be sold by weight and that the net quantity of contents, including the propellant, be so labeled on the packace. The test of the accuracy of the quantity declaration is accomplished in four steps: (1) Establish the gross weight of the package. (2) Expel the entire contents of the package with the propellant, following the instructions furnished by the packer. (3) Determine the tare weight of the container. (4) Subtract the tare weight from the gross weight to determine the net weight of the contents. 
In order to make the Model State Regulation Pertainng to Packages perfectly clear in relation to aerosol containers, the committee recommends that Section 3.2. of this regulation be amended by inserting in line 12, after the comma following the word "That": "if the conmodity is packaged in an aerosol container, the declaration shall be in terms of weight (including the propellant): And provided further 'That,". This will make the section read as follows:

3.2. TERMS-WEFGHT, MEASURE, OR COUNT.-The declaration of the quantity of a particular commodity shall be expressed in such terms of weight, measure, or count, or a combination of count and weight, measure, or size, as have been firmly estahlished in general consumer usage and trade custom and as give accurate information as to the quantity of the commodity. But if there exists no firuly established general consunel usage and trade custom with respect to the telms used in expressing such declaration of quantity, the declaration shall be in terms of iiquid measure if the commodity is liquid, or in terms of weight if the commodity is solid, semisolid, viscous, or a mixture of solid and liquid: Provided. That, if the commodity is packaged in an aerosol container, the declaration shall be in terms of weight (including the propellant) : And provided fwther 'That, if the commodity is a textile material, the declaration shall be in telous ot linear measure unless the material is one in which there exists a firmly established general consumer usage and trade custom to declare the quantity in telms of weight, in which case the declaration may be in terms of weight.

(Item 5 was adlupted by voice vote.)

The conmittee is appreciative of the assistance rendered to it in its deliberations by all those who have made oral or written comment on any of the zatters on the committee agenda, and records its thanks to weights and measures oflicials, representatives of equipment mamfacturers, and others for this cooperation.

\author{
Romert Whisurs, Chairman \\ .T. G. Gustafson \\ G. I. JoHnson \\ .T. H. LEWIS \\ H. M. TURrwu \\ WV. S. Busswr, Secretary
}

(On motion of the committee chaiman, seconded from the floor, the report of the Conference Committee on Laws and Regulations was adopted by voice vote.)

(The benediction was delivered by Mr. John H. Lewis of the State of Washington. Thereupon at 10:45 a.n. the 46th National Conference on Weights and Measures adjourned sine dic.) 
PERSONS ATTENDING TIE CONFERENCE

Delegates-State, City, and Comnty Otficials Alizona

Stilte

C. O. Smith, Deputy Inspector, State Department of Weights and Measures, Room 139 Capitol Bldg., Phoenix.

\section{CALIFORNIA}

State

W. A. Kerlin, Chief, Bureau of Weights and Measures, Department of Agriculture, 1220 "N" St., Sacramento.

Mrs. H. E. Nelson, Consumer Counsel, Governor's Office, State Capitol, Sacramento.

Countr:

Alameda_......... R. H. Fernsten, County Sealer of Weights and Measures, 333 Fifth Street, Oakland.

Kern

A. D. Rose, County Sealer of Weights and Measures, 1116 E. California Avenue, Bakersfield.

Los Angeles........ F. M. Rayuund, County Sealer of Weights and Measures, 3200 N. Main Street, Los Angeles.

San Diego

Santa Clara

H. J. McDaDE, County Sealer of Weights and Measures, 1480 "F" St., San Diego.

Ventura

D. R. Pratt, County Sealer of Weights and Measures, 142 N. Market St., San Jose.

E. H. Black, County Sealer of Weights and Measures, P.O. Box 1610, Ventura.

\section{COLORADO}

State

H. N. Duff, State Supervisor, Weights and Measures Section, Department of Agriculture, State Services Bldg., 1525 Sherman St., Denver.

H. H. Houston, Director, Oil Inspection Department, 1024 Speer Bldv., Denver.

\section{CONNECTICUT}

State

F. M. Greene, Chief, Division of Weights and Measures, Department of Consumer Protection, State Office Building, Hartford.

City:

Hartford

Nathan Kalechman, City Sealer of Weights and Measures, City Hall.

Middletown

Peter Grassi, City Sealer of Weights and Measures, Post Office Box 223.

New Britain

A. J. Albanese, City Sealer of Weights and Measures, City Hall.

\section{DISTRICT OF COLUMBIA}

Weights, Measures, and Markets Branch, Department of Licenses and Inspection, Room 227 Esso Bldg., 261 Constitution Ave., N.W., Washington, D.C.

Dist rict

J. T. KEnNEDY, Chief.

J. M. Boucher, Supervisor.

J. T. Bennick, Inspector and Investigator.

R. E. BradLex, Inspector and Investigator.

IV. R. Cornelius, Inspector and Investigator.

D. K. Forbes, Inspector and Investigator.

Kenneth Hayden, Inspector and Investigator.

H. P. Hutchinson, Inspector and Investigator.

W. H. JENnings, Inspeetor and Investigator.

G. P. Kíosnos, Inspector and Investigator.

I. I. WAGNER, JR., Inspector and Investigator.

W. W. WELls, Inspector and Investigator. 


\section{FLORIDA}

State

City:

Jacksonville

Miami

State

City:

Chicago

State

County:

Gibson.

Grant

Howard

Knox

St. Joseph.

Vigo City:

Evansville

Gary

Indianapolis

New Albany.

Sonth Bend
Nalus Berryman, Director, Division of Standards, Department of Agriculture, Room 107 Nathan Mayo Bldg., Tallahassee.

NaT MAYo, Director, Inspection Division.

IV. R. Drxon, Field Supervisor.

H. E. Crawford, Inspector, Department of Weights and Measures, Room 203 City Hall.

II. E. Howard, Supervisor, Division of Trade Standards, Coconut Grove Station, P.O. Box 708.

\section{GEORGIA}

P. I. Morris, Jr., Dircetor, Weights and Measures Division, Department of Agriculture, 19 Hunter St., S.IV., Atlanta.

J. W. D. HArvey, State Oil Chemist, State Oil Laboratory, Department of Revenue, 264 Capitol Pl., Atlanta.

\section{ILLINOIS}

11. L. Goforth, Superintendent, Division of Feeds, Fertilizers, and Standards, State Fairgrounds, 531 E. Sangamon Avcnue, Springfield.

R. J. FAHY, Chief Deputy Inspector, Department of Weiglits and Measures, Room 302 Central Office Building, $320 \mathrm{~N}$. Clark St.

Robert Scanlon, Supervising Deputy Inspector.

\section{INDIANA}

R. E. MEEK, Director, Division of Weights and Measures, State Board of Health, $1330 \mathrm{~W}$. Michigan St., Indianapolis.

IV. R. Sevier, County Inspector of Weights and Measures, 112 E. Emerson St., Princeton.

R. C. Parks, County Inspector of Weights and Measures, Court House, Marion.

I. R. Frazer, County Sealer of IVeights and Measures, $113 \mathrm{~N}$. Washington St., Kokomo.

II. D. LIDDIL, County Inspector of Weights and Measures, 840 State St., Vinecnnes.

S. C. Grzeskowiak, County Inspector, Division of IVeiohts and Mcasures, Room 11 Court House, South Bend.

R. J. Silcock, County Inspector of Weights and Measures, Room 5 Court House, Terre Haute.

J. M. BrITe, City Inspector of Weights and Measures, $10 \mathrm{~S}$. Lafayctte St.

C. C. Morgan, City Sealer of Weights and Measures, City 11 all.

II. R. Copeland, Supervising Inspector, Department of Weights and Measures, 202 N. Alabaina St.

M. A. Steinert, City Inspector of Weights and Measures, 37 W. Fifth St.

13. S. Cichowicz, City Inspector of Weights and Measures, City Hall.

\section{KANSAS}

State

J. F. True, State Sealer, Division of Weights and Measures, State Board of Agriculture, State Office Building, Topeka.

J. L. O'Nelle, State Inspector, Division of Weights and Measures, IVilliansburg. 
Cit $y^{*}:$

Fitusils City

J. O. Sihughter, Jn., City Inspector of Weights and Measures, Department of Finance and Revenue, City Hall.

\section{KENTUCKY}

Stilte

G. I. Jounson, Director, Dirision of Weights and Measures, Department of Agriculture, Capitol Annex, Frankfort.

J. A. HALEr, State Inspector, 1829 James David Ct., Owensboro.

\section{LOUISIANA}

State

F. F. Thonpson, Chief Chemist, P.O. Box 8374 University Station, Baton Rouge.

\section{MAINE}

State

H. D. Robinson, Deputy Sealer of Weights and Measures, Department of Agriculture, State House, Augusta.

City:

Portlind

C. J. Wrlls, JR., City Sealer of Weights and Measures, Room 16, 389 Congress Street.

\section{MARYLAND}

State

P. E. Nystrom, Director, Agriculture Extension Service, State Board of Agriculture, University of Maryland, College Park.

J. E. Mahoner, State Superintendent of Weights and Measures, Department of Markets, State Board of Agriculture, University of Maryland, College Park.

R. N. Smith, Assistant Superintendent.

IACY DEGRANGE, State Inspector.

R. W. Glendenning, State Inspector, Post Office Box 356, Chestertown.

County:

Iİontgomery

E. IV. Buckisx, Director, Department of Inspections and Licenses, County Office Building, Rockville.

L. B. Morton, County Inspector of Weights and Measures.

J. P. Soltrsiak, County Inspector of Weights and Measures.

Prince George's _..._. R. J. Cond, Chief Inspector of Weights and City:

Baltimore Measures, Court House, Upper Marlboro.

G. H. Leithauser, Chief Inspector, Division of Weights and Measures, Room 1106 Municipal Building.

\section{MASSACIIUSETTS}

State

IV. C. Hughes, Head Administrative Assistant, Division of Standards and Necessaries of Life, Department of Labor and Industries, State House, Boston.

A. E. Jenest, State Inspector, $210 \mathrm{Elm}$ St. Greenfield.

City :

Boston

J. F. McCarthr, City Sealer of Weights and Measures, Room 105 City Hall Annex.

Brookline

N. A. SackNoff, Deputy Sealer of Weights and Measures, c/o Health Department, 11 Prospect St., Town Hall.

Cambridge

A. T. Anderson, City Sealer of Weights and Measures, Room 202 City Hall.

Everett Measures, 48 E. Elm St. 
Fitchburg

Newton

Quillcy.

Somerville

State

County

IVashtenaw City:

Dearborn

Detroit

Royal Oak

City

Minne:tpolis

St. Loulis

State

State

City:

Manchestel
Raymond Reburfo, Assistant Director, Division of llant Industry, Department of Agriculture, 350 Capitol Hill Avenue, P.O. Box 1209, Reno.

\section{NEW IIAMPSIIRE}

IV. T. Deloge, City Sealer of Weights and Measures, City Hall, 42 Elı St.

J. E. Bowes, City Sealer of Weights and Measures, City Hall, Newton Centre.

H. H. Hugres, City Sealer of Weights and Measures, City Hall Annex, 63 Saville Row.

J. F. Caser, City Sealer of Weights and Measures, Public Works Building.

\section{MICIIIGAN}

J. L: Littlefield, Chief, Foods and Standards Division, Department of Agriculture, Lewis Cass Building, Lansing.

Robert Blackburn, State Sealer of Weights and and Measures Officials), 4152 Omaha, Grandville.

G. P. Smith, County Sealer of Weights and Measures, County Building, Ann Arbor.

J. A. Huches, Superintendent, Department of Licenses, Weights, and Measures, 13030 Hemlock Ave.

J. T. Daniflu, Deputy Sealer, Bureau of Weights and Mcasures, 2693 Eighteenth St.

G. E. Ruthedge, City Seaker of Weights and Measures (Michigan Association of Weights and Measures Officials), 211 William St.

\section{MINNESOTA}

W. E. Czara, Supervisor, Department of Weights and Measures, Railroad and WVarehouse Commission, One Flour Exchange, Minneapolis.

O. K. WARnlof, State Inspector, $325 \mathrm{~S}$. Third St., Minneapolis.

J. G. Gustarson, Chief Inspector, Department of Licenses, Weights, and Measures, Room 101-A City Hall.

IV. K. I.eONAR1, Inspector.

\section{MISSOUII}

G. IV. BAY, Chief Inspector, Weights and Measures Division, Department of Agriculture, Jefferson City.

J. A. Bernard, Commissionel of Weiglits and Measures, Roon 12 City Hall.

A. H. Ditrrich, Chief Inspector, Bureau of Weights and Measures, Division of Markets and Standards, Department of Agrieulture, State Oflice Building, Concord.

A. R. Roy, State Inspector, 16 Monroe St., Concord.

Franerick Young, State Inspector, 204 Gilford St., Manchester.

F. A. Cienest, City Sealer of Weights and Measures, 180 Franklin St. Measures (Michigan Association of Weights 
State

County:

dtantic

Bergen

Burlington

Camden

Cumberland

Essex

Mercer

Monmouth

Warren

City:

Bayomne

Camden

Fair Lawn

Garfield

Jersey City

Kearny

Linden

Nutley
IV. H. Cramer, State Superintendent, Division of Weights and Measures, Department of Law and Public Safety, 1S7 W. Hanover St., Trenton.

S. H. Christie, JR., Deputy State Superintendent.

R. K. Bodenweser, Supervisor of Enforcement.

A. T. Suth, Supervisor of Technical Serviees.

J. R. BIrD, Senior Technieian.

J. E. Mrers, County Superintendent of Weights and Measures, $350 \mathrm{~S}$. Egg Harbor Rd. Hammonton.

M. J. Santmauro, County Superintendent of IVeights and Measures, 66 Zabriskie St. Hackensaek.

E. E. DAwson, Assistant County Superintendent.

D. F. Hummel, Superintendent of Weights and Measures, County Offiee Building, 49 Water St., Mt. Holly.

A. C. Becker, County Superintendent of Weights and Measures, City Hall, Camden.

G. S. Franks, County Superintendent of Weights and Measures, County Court House, Bridgeton.

W. H. Schneidewind, County Superintendent of Weights and Measures, 278 New St., Newark.

R. M. Bodenweiser, County Superintendent of Weights and Measures, Court Housc, Trenton.

IV. I. Thompsos, County Superintendent of Weights and Measures, P. O. Box 74, Allenhurst.

J. A. J. Bovie, Assistant County Superintendent. W. G. Dox, Assistant County Superintendent, 12 Campview Pl., Keansburg.

J. J. Elker, Inspector, 1219 First Ave., Asbury Park.

William Milder, County Superintendent of Weights and Measures, 317 Pennsylvania Ave., Paterson.

G. E. Connoluy, County Superintendent of Weights and Measures, Court House, Belvidere.

J. G. VAYDA, Municipal Supcrintendent of Weights and Measures, Municipal Building, 26th St. and Ave. C.

Alfred DiPiero, Municipal Superintendent of Weights and Measures, City Hall.

Oscar Haug, Municipal Superintendent of Weights and Measures, Plaza Building.

Charles Benanti, Municipal Superintendent of Weights and Measures, 1.47 Frederick St.

H. J. Mrers, Municipal Superintendent of Weights and Measures, City IIall.

Janes Pollock, Municipal Superintendent of Weights and Measures, Town Hall, 402 Kearny Ave.

L. T. Reagan, Municipal Superintendent of Weights and Measures, Room 206, City Hall.

Roy GundersdorfF, Director, Public Affairs Department.

W. L. Callanas, Municipal Supcrintendent of Weights and Mieasures, Town Hall, Chestnut St. 
Passaie_........... PAUL DeVries, Municipal Superintendent of Weights and Measures, City Hall.

Joseph Shaw, Assistant Munieipal Superintendent.

Paterson_..._._._._. J. P. Leovard, Munieipal Superintendent of Weights and Measures, 115 Van Houten St.

W. J. Kenoe, Jr., Assistant Munieipal Superintendent.

Trenton_......... R. J. Boney, Municipal Superintendent of Weights and Measures, 324 East State, City Hall Annex.

Union City

A. O. Oslund, Municipal Superintendent of Weights and Measures, City Hall, 3715 Palisade Avenue.

\section{NEW MEXICO}

State

C. B. Whicham, Chief, Division of Markets, Weights and Measures, Department of Agrieulture, Box 457, University Park.

\section{NEW YORK}

State

J. F. MADDEN, Direetor, Bureau of Weights and Measures, Department of Agriculture and Markets, State Offiee Building, Albany.

County:

Dutchess

J. E. DEAn, County Sealer of Weights and Measures, 47 Fuller Ave., Hyde Park.

Genesee.

G. A. Pullman, County Sealer of Weights and Measures, 19 Buffalo St., Bergen.

Monroe.

E. D. Hubble, County Sealer of Weights and Measures, 1400 South Ave., Rochester.

R. J. Veness, Deputy County Sealer.

Nissau

Ronert Willians, County Sealer of Weights and Measures, 58 Third Ave., Mineola.

A. W. Weidner, Jr., Assistant County Sealer.

Wayne

II. H. WRIGHT, County Sealer of Weights and Neasures, 30 Catherine St., Lyons.

City:

Binghamton

E. N. Volkay, Sealer of Weights and Measures, 54 Hawley St.

Glen Cove

E. T. Hunter, City Sealer of Weights and Measures, City Hall.

Ithaea

E. P. Nedrow, City Sealer of Weights and Measures, City Hall.

Laekawanna

J. J. Seres, City Sealer of Weights and Measures, 84 Rosary Ave.

Roehester.

A. C. Samenfink, City Sealer of Weights and Measures, Rochester Publie Market.

Syraeuse

J. M. Byrne, City Sealer of Weights and Measures, 101 Pine St.

Jonkers

Joms Drmase, City Sealer of Weights and Mleasures, City Hall.

\section{NOR'TI CAROLINA}

State

C. D. BAucom, Superintendent, Weights and Measures Division, Department of Agriculture, Agrieulture Building, Raleigh.

J. I. Moore, Field Supervisor.

M. L. Kinlaw, State Inspeetor, 315 Cross St., Hope Mills.

\section{OIIIO}

State

C. W. VAN Scholk, Chief, Division of Weights and Measures, Department of Agriculture, Reynoldsburg. 
County:

Ashland

Clark

Medina

Ottawa

II arren

City :

Cincinnati

Youngstown

State

City:

Oklahoma City.

Tulsa

State

State

City:

Altoona

Commonwealth

State

City:

Cranston

Providence
A. E. Diaz, Head, Weights and Measures Division, Economic Stabilization Administration, P.O. Box 4183, San Juan.

\section{RHODE ISLAND}

J. H. Nigh, Deputy County Sealer of Weights and Measures, c/o County Auditor, Ashland. D. W. LAWson, Deputy County Sealer of Weights and Measures, c/o County Auditor, Springfield. R. IV. Searles, Deputy County Sealer of Weights and Measures, County Board of Education Building, Medini.

Rudolph Starkloff, Deputy County Sealer of Weights and Measures, Box 208, Port Clinton. J. D. Templetos, County Auditor, Court House, Lebanon.

IV. E. G. Rhein, Superintendent, Division of Markets, Weights and Measures, 316 George St.

F. B. Jones, City Sealer of Weights and Measures, City Hall.

\section{OKLAHOMA}

R. W. Poweld, Director, Marketing Division, State Board of Agriculture, 122 Capitol Bldg., Oklahoma City.

W. U. Lindsay, Chief, Inspector, Weights and Measures, City Hall.

J. L. Sunth, City Inspector of Weights and Measures, City Hall, Fourth and Cincinnati.

\section{OREGON}

W. B. Steele, Deputy State Sealer of Weights and Measures, Department of Agriculture, Agriculture Bldg., Salem.

\section{I'ENNSYLVANIA}

Miss Genevieve Blatt, Secretary, Department of Internal Afiairs, Capitol Bldg., Harrisburg.

W. C. Serler, Deputy Secretary.

H. M. Turrell, Director, Bureau of Standard Weights and Measures.

E. A. VADELUND, Assistant Director.

A. A. Florio, State Inspector of Weights and Measures, 84 Hudson St., Slovan.

Marion Grashion, State Inspector, R.D. \#1, Grindstone.

J. W. Schimel, State Inspector, Box 17, Analomink.

V. J. Shotwell, State Inspector, 404 East 9th St., Berwick.

R. I. Cummers, City Inspector of Weights and Measures, City Hall.

E. R. Fisher, State Sealer of Weights and Measures, Departinent of Labor, Veterans Memorial Building, 83 Park St., Providence.

J. J. Adaus, City Sealer of Weights and Measures, 89 Bartlett Ave.

William D'Abate, Superintendent of Weights and Measures, 173 Sisson St. 


\section{SOUTII CAROLINA}

State

State

\section{County:}

Davidson County -

C. H. Stender, Assistant to Commissioner, Department of Agriculture, P.O. Box 1080, Columbia.

E. IV. Baldentine, Supervisor, Weights and Measures.

\section{TENNESSEE}

Mat' Jennings, Director, Division of Marketing, Department of Agriculture, Melrose Station, Box 9039, Nashville.

G. R. Lnnghni, County Sealer, 1417 Ordway Pl., Nashville.

\section{TEXIS}

State

R. H. Koovrz, Assistant Commissioner, Department of Agriculture, Capitol Station, Austin.

City:

Dallas

Boв Bord, Deputy Commissioner.

F. G. Yarbrovgh, Chief Deputy of Weights and Measures, 303 City Hall.

\section{VIRGINIA}

State

P. C. Brinkley, Commissioner, Department of Agriculture and Immigration, 302 Governor St.. Richmond.

T. C. IlARRIS JR., Supervisor, Weights and Measures Section, Department of Agriculture and Immigration, 1200 East Main St., Richmond,

J. F. lyues, Field Supervisor.

G. P. LAtimer, State Inspector, 107 Tazewell Ave., Cape Charles.

J. W. Rogers, State Inspector, R \#1, Box 645, Suffolk.

C. E. Whituan, Field Supervisor, Scale Maintenance, Department of Highways, $1221 \mathrm{E}$. Broad st., Richmond.

City:

Alexandria

Danville

Norfolk

Petersburg

Richmond

Roanoke

State

City:

Seattle.
1. W. VEZINA, Sealer of Weights and Measures, 405 Cameron St.

C. II. Wrens, City Sealer of Weights and Measures, Curb Market Bldg., Spring St.

IV. F. BRADLEY, Chief, Bureau of Weights and Measures, Department of Public Safety, City Hall.

C. R. Brancu, City Sealer of Weights and Measures, City Hall.

J. G. WILLLAMS JR., Chief, Bureau of Weights and Neasures, Room 112 The Mosque, Laurel and Main Sts.

A. B. Moody JR., Inspector.

J. M. Hudgins, Chief. Department of Weights and Measures, City Market Bldg.

\section{WASHINGTON}

J. 11. Jewr, Chief, Weights and Measures Section, Department of Agriculture, P'O. Box 120 , Olym pia.

D. M. Turnbulu, Director, Division of licenses and Standards, Office of the Comptroller, Room 100, County-City Building. 


\section{WEST VIRGINLA}

State

LAWRENCE BARKER, Commissioner, Department of Labor, State Capitol, Charleston.

Matr Johnson, State Inspector, 1786 Arlington Blvd., Huntington.

\section{WISCONSIN}

State

C. L. JACkson, Chief, Division of Economic Practices, Department of Agriculture, State Capitol, Madison.

T. E. Wildrick, Field supervisor.

City:

Beloit

1. IV. Raymond, City Sealer of Weights and Measures, Municipal Center.

Green Bay .......... P. Tilleman, City Sealer of Weights and Measures, City Hall.

Kenosha_............ J. P. KucherA, City Sealer of Weights and Measures, Room 15, City Hall.

Milwaukee

P. J. Dwyer, Deputy City Sealer of Weights and Measures, 1331 North 5 th St.

Racine_............. Robert Zierten, City Sealer of Weights and Measures, City Hall.

West Allis

J. J. Persak, Deputy City Scaler of Weights and Measures, City Hall.

\section{Advisory Members}

JAy J. JAcobsox, Legislative Assistant to Senator Maurine Neuberger.

L.S. Department of Commeree:

Luther H. Hodges, Secretary of Commerce.

National Bureau of Stanclards:

Director's Office:

A. V. Astin, Director.

A. T. McPherson, Associate Director for Engineering.

Office of Weights and Measures:

IV. S. Bussey, Chicf.

M. W. Jensen, Assistant Chief.

L. V. Judson, Physicist.

R. IV. SuIth, Consultant (Honorary Life Member).

H. F. Wollin, Engineer.

G. H. Borders, Library Assistant.

Mrs. F. C. BeLL, Administrative Assistant.

Mrs. E. I. Brueckner, Secretary.

Mrs. M. M. Brodnerkel, Secretary.

Office of Technical Information:

IV. R. TILley, Chief.

J. F. Reilly, Publications Editor, Information Section.

C. C. ATwoon, Information Officer.

Mrs. Claire Patterson, Administrative Assistant.

Metrology Division:

I. B. Macurdy, Chief, Mass Unit, Mass and Scale Section.

H. E. Almer, Physical Science Technician, Mass Unit, Mass and Scale Section.

H. A. Bowman, Physicist, Mass Unit, Mass and Scale Section.

P. S. Shoenfeld, Physicist, Mass Unit, Mass and Scale Section.

A. M. Garfield, Physical Science Aid, Mass Unit, Mass and Scale Section.

E. M. Bropy, Student Assistant, Mass Unit, Mass and Scale Section.

H. H. Russelu, Chief, Scale Unit, Mass and Scale Section.

H. L. BAdger, Physicist, Scale Unit, Mass and Scale Section.

R. W. Crouch, JR., Technologist, Photometry and Colorimetry Section.

J. C. Hughes, Acting Chief, Volumetry and Densimetry Section.

Analytical and Inorganic Chemistry Division:

H. S. Peiser, Consultant in Weighing. 
U.S. Department of Agriculture:

D. R. STokes, Agricultural Economist, U.S. Department of Agriculture, Washington, D.C.

D. R. MAскаY, Agricultural Engineer, Agricultural Engineering Research Division, Agricultural Engineering Laboratory, Agricultural Research Center, Beltsville, Maryland.

Fred Stein, Dairy Marketing Specialist, U.S. Department of Agriculture, 14 th and C St., S. IV., Washington, D.C.

Milton Johnson, Marketing Specialist, Regulatory Branch Fruit and Vegetable Division, Agricultural Marketing Service, Washington, D.C.

R. D. Thompson, Chief, Scales and Weighing Branch, Packers and Stockyards Division, Agrieultural Marketing Service, Washington, D.C.

M. IV. Stephens, Scales and Weighing Specialist, 3507 Department of Agrieulture Bldg., Washington, D.C.

J. L. Alcorn, Scales and Weighing Specialist, Room 225 Livestock Exchange Bldg., Sioux City, Iowa.

H. C. Kennetr, JR., Marketing Specialist, Poultry Division, Agricultural Marketing Service, Washington, D.C.

Federal Trade Commission:

D. J. Murpir, Assistant Director, Bureau of Litigation, Washington, D.C.

IV. B. Snow, Jr., Chief, Division of Stipulations, Federal Trade Commission Bldg., Washington, D.C.

U.S. Department of Health, Education, and Welfare:

G. P. LARrICK, Commissioner, Food and Drug Administration, Washington, D.C.

L. M. Beacham, Deputy Director, Division of Food, Bureau of Biological and Physical Sciences, Food and Drug Administration, Washington, D.C.

U.S. Department of the Treasury:

E. IV. Teagarden, Engineer, Division of Technical Services, Bureau of Customs, Washington, D.C.

\section{Associate Members-Manufactures of Weighing and Mcasuring Devices}

Ace Glass, Ine.: T. A. LILly, Sales Representative, 43 So. Early St., Alexandria, Va.

Ainsworth, Im., \& Sons, Ine.: Nicholas Voupe, Eastern District Manager, 3 Lakeview Ave., Boonton, N. J.

Badger Meter Minufacturing Co.: NI. E. HAnTz, Director of Research and Engineering, 4545 West Brown Deer Rid., Milwakee, Wis.

Bowser, Inc.:

E. J. Reinhart, Manager, Customer Service, 1302 East Creigliton Ave., Fort Wayne, Ind.

IV. F. Gerdon, Assistant Manager.

Brodie, Ralph N., Co.:

C. J. McCafrrey, Vice President, 550 South Columbus Ave., Mount Vernon, N.Y.

D. IV. Kinnster, Special Sulesman.

H. E. Siebold, Sales Engineer, 3314 Chrysler Building, New York, N. Y.

Cardinal Scale Manufacturing Co.: WV. IH. Perry, 203 E. Daugherty, Webb City, Mo.

Chatillon, John, \& Sons: G. C. Rentey, Vice l'resident, Sales, 85-93 Cliff St., New York, N.Y.

Continental Can Co., Inc.:

T. P. MeGlynn, Manager, Product and Mallet Development, P.O. Box 1159, 34) Oraton Street, Newark, N.J.

Seymour Kurtz.

Creamery Package Manufacturing Co.: L. T. Gustarson, General Sales Engineer, 1243 West Washington Blyd., Chicago, IH.

Crow Scales, Inc.: C. Crow, President, P.O. Box 3092, Waco, Tex.

Dairy Equipment Co.: I. S. HART, Vice President, 1444 E. Washington Ave., Madison, IV is.

Detecto Scales, Inc.: M Ack Rape, Vice President, 540 Park Ave., Brooklyn, N. Y.

Dixie Cup Division of American Can Co.: J. G. Rorers, Consultant, Weights and Measures, 47:30 Stevens Drive, Sarasota, Fla.

Dover Corp. Division of OPIV: R. II. Scmubman, Manager, Government Sales, 2735 Colerain Ave., Cincinnati, Ohio. 
Exact Weight Seale Co.:

II. A. Scheuren, President, 538 East Town St., Columbus, Ohio.

II. J. Schieser, Vice President.

Bruce TAYLOR, General Manager.

lix-Cell-O Corp.:

J. F. Flyxn, Service Manager, 1200 Oakman Blyd., Detroit, Mich.

ARNOLD DORBECK.

Factory Equipment Co.: J. F. Feind, President, 190 State St., Bloomfield, N.J.

Fairbainks, Morse \& Co.:

C. G. Gehrixger, Director of Marketing, Scale Division, 19-01 Route 208, Fair Lawn, N.J.

R. E. Hess, Sales Manager, Fairlawn Ind. Park, Fair Lawn, N.J.

J. M. Lixiehax, Field Engineer, 659 E. 25 th St., Baltimore, Mal.

T. S. Pevers, Supervisor, Service Department.

Richard Wasniak, National Manager, Service, 600 South Michigan Ave, Chicago, Ill.

Gilbert \& Barker Manufacturing Co.:

WilliaM Kear, Manager, Sales Service, West Springfield, Mass.

F. L. Shephard, Manager, Sales Engineering.

Cranberg Corp.: W. MI. Mildigan, Sales Manager, Eastern Division, 4895 th Ave., New York, N.Y.

Gurlev, W. \& L. E.: F. G. Williams, Washington Representative, 5514 Nevada Ave., N.W., Washington, D.C.

Hobart Manufacturing Co.:

K. C. Allen, Vice President, Seale Operations, 448 Huffman Ave., Dayton, Ohio.

M. E. Bone, Weights and Measures Representative.

E. A. Reussenzern, Chief Scale Engineer, Dayton Scale Division.

Howe Scale Co.:

R. F. Straw, Vice President, 685 Stewart Ave., S. W., Atlanta, Ga.

Pat Pratico, Quality Control Manager, 2941 Scale Ave., Rutland, Vt.

G. D. Wilkinson, National Service Manager.

Kianawha Valley Scale Service Co.: P. E. Bradbury, Owner, P.O. Box 221, Dunbar, IV. Va.

Knox Glass, Inc.: II. K. Knight, Knnox, Pa.

Lily-Tulip Cup Corp.: M. W. WILDER, 122 E. 42nd St., New York, N.Y.

Liquid Controls Corp.: G. B. Richards, Commonwealth Ave., North Chicago, Ill.

Lockheed Electronics Co:

Michael Pappas, Design Mechanical Engineer, Information Technology Division, Metuchen, N.J.

Donato Sammarco, Sales Representative.

Daniel Semels, Assistant Division Manager.

Richard Weinberg, Director of Operations.

MeIntyre, John J., Sons, Inc.: F. L. MICIxтYre, President, 514-16 Inom St., Philadelphia, $\mathrm{Pa}$.

Measuregraph Co.: F. L. WALL, Representative, 6603 Arlington Blvd., Falls Church, Va.

Iiller, Byron, \& Associates: B. D. Miller, Owner, 7712 Georgia Ave., N.W., Washington, D.C.

Iurphy, L. R., Scale Co.:

L. R. Murphy, President, 1610-12 N. "C"' St., Sacramento, Calif.

Kenneth Murphy.

Neptune Meter Co.:

Fred IUtch, Sales Manager, Petroleum and Industrial Meters, 34 th St. \& 47 th Ave., Long Island City, N.Y.

II. A. Medford, Engineer.

E. F. Wemmann, Assistant Chief Engineer.

Nícol Scales, Inc.: W. F. Nicol, President, 1315 S. Akard St., Dallas, Tex.

Owens-Illinois Glass Co.: F. B. Busch, Specifications Engineer, P.O. Box 1035, Toledo, Ohio.

Penn Scale Manufacturing Co., Inc.: Sydney Black, President, 150 W' Berks St., Philadelphia, $\mathrm{Pa}$.

Pottermeter Corp.: MI. BAYER, Industrial Sales MIanager, U.S. Route \#22, Union, N.J.

Revere Corp. of America:

C. IV. Silver, Sales Manager, Wallingford, Conn.

H. L. ZuPP, Sales Engineer. 
Richardson Scale Co.: I. H. Richardson, President, Clifton, N.J.

Rockwell Manufacturing Co.: A. J. Koмıch, Product Manager, Liquid Meters, Box 450 , Statesboro, Ga.

Sanitary Scale Co.:

E. C. KARP, Vice President, Manufacturing and Engineering, 910 E. Lincoln Ave., Belvidere, Ill.

Sven Berglund, Plant Engineer.

Sauter, August, of New York, Inc.: H. G. Shimp, Jr., Manager, 866 Willis Ave., Albertson, Long Island, N.Y.

Seraphin Test Measure Co.: T. A. Seraphin, General Manager, 1314 N. 7th St., Philadelphia, Pa.

Smith, A. O., Corp.: I. G. Blumenberg, Manager, Field Service, Smith-Erie Division, 1602 Wagner Ave., Erie, Pa.

Stimpson Computing Scale Co.: J. J. WAAGE, President, 829 lıgan St., Louisville, Kiy.

Streeter-Amet Co.:

R. T. Isham, President, Grayslake, Ill.

C. L. Richard, Consultant, 703 S. Ola Vista, San Clemente, Calif.

Suburban Rulane Gas Co., John MaCIntosh, Chief Engineer, 2317 Thrift Rd., Charlotte, N.C.

Symington Wayne Corp.:

W. J. DuBsky, Nanager of Engineering, Wayne Pump Co. Division, Salisbury, NId.

F. W. Love, Engineering Department.

Thatcher Glass Manufacturing Co.:

R. E. Chapman, Elmira, N.Y.

A. C. Thomas, Service Department.

l. E. Young, Manager, Customer Service.

Thurman Scale Co.: J. R. Schatffer, Vice President, 1939 Refugee Rd., Columbus, Ohio.

Tokheim Corp.: Willinu Louthan, Manager, Field Service, 1600 Wabash Ave., Fort Wayne, Ind.

Toledo Scale Co.:

F. D. Instone, Vice President, Toledo, Ohio.

D. B. Kendalu, Nanager, Product Engineering.

J. G. LEWIS, Manager, Marketing Research.

R. V. Miller, National Manager of Weights and Measures and Sanitary Standards.

R. E. Lenox, District Manager, 3329 8th St., N.E., Washington, D.C.

Torsion Balance Co.: J. P. Slane, Eastern Sales Representative, 35 Monhegan St., Clifton, N.J.

Troemner, Henry, Ine.: C. F. RosicA, Sales Manager, 22nd and Master Sts., Philadelphia, P̉a.

Veeder-Root, Inc.:

J. J. Brannick, Sales Manager, Computer Division, 70 Sargeant St., Hartford, Conn.

A. E. Mchíever, Sales Manager, Master Meter Duplicator Division.

Voland Corp.: Bernard Wasko, Chief Engineer, 27 Centre Ave., New Rochelle, N.Y.

Wood, John, Co.:

L. G. Close, Manager, Mid-Atlantic States, Bennett l'ump Division, 2127 N. Charles St., Baltimore, MId.

MI. S. Godsman, Serviee Manager, Bennett Pump Division, Broadway and Wood Sts., Muskegon, Mich.

W. M. Hoxie, Service Department.

\section{Associate Members-Associations, Business and Industry, and Railroads}

Anerican Institute of Baking: W. M. Schier, Maintenance Inspector, 400 E. Ontario St., Chicago, Ill.

American Petrolem Institute, J. L. Moss, Consultant, Division of Transportation, $1625 \mathrm{~K}$ St., N.W., Washington, D.C.

American Standards Association: A. C. Hutron, Staff Engineer, c/o National Bureau of Standards, Washington, D.C.

Association of American Soap and Glycerine Producers, Inc.: R. W. PEet, Manager, 295 Madison Ave., New York, N.Y. 
Cook Chemical Co.: Dox Guolsox, Chief Chemist, 2500 Summit, Kansas City, Mo.

Cooperative Le'agne of the U.S.A.: J. T. Jennings, Associate Director, Washington Office, 1025 Vermont Are., N.W., Washington, D.C.

Corn Products Co: Virginia McCarthr, Statistician, 99 Are. A, Bayonne, N.J.

Dairy Industries Supply Association: D. H. Wrlulams, Technical Director, $11+5-19$ th St., N.W., Washington, D.C.

Distilled Spirits Institute, Inc.:

R. W. Corse, President, 1132 Pennsylya nia Bldg., Washington, D.C.

B. J. O'Callaghax, Director, Press and Public Relations Division, 425 13th St., N.W., Washington, D.C.

Esso Standard: L. L. KenNedr, Manager, Construction and Maintenance, $500 \mathrm{~N}$. Broad St., Elizabeth, N.J.

Gasoline Pump Manufacturers Association: G. T. Wrigrt, Managing Director, 551 Fifth Are., New York, N.Y.

General Foods Corp.:

C. A. Clark, Fire-Safety and Sanitation Coordinator, 250 North St., White Plains, N.I.

J. J. HALSEY, Consultant, Quality Services.

General Mills, Inc.: O. A. OudaL, Assistant Director, Products Control, 9200 Wayzata Blyd., Minneapolis, Minn.

Glass Container Manufacturers Institute, Inc.: C. E. Wagner, Development Engineer, 99 Park Ave., New York, N.Y'.

Grand Union Co.:

M. R. Socolof, General Manager and Executive Vice President, Washington Division, 7000 Sheriff Rd., Landover, Md.

Earl Redner, Superintendent of Stores.

Greenbelt Consumer Services, Inc.:

E. D. Jones, 2706 Harris Are., Wheaton, Md.

Aileen Newais, 10703 Clerinont Ave., Garrett Park, Md.

Liquefied Petroleum Gas Association: W. H. Johnson, Staff Engineer, 11 S. LaSalle St., Chicago, Ill.

Mayer, Oscar, \& Co.:

J. C. BARD, Director of Product Research, 910 Mayer Ave., Madison, IVis.

D. L. PACL, General Product Controller.

Mirk Industry Foundation: E. B. KellogG, Director of Technical Services, 114519 th St., N.W., Washington, D.C.

National Association of Dairy Equipment Manufacturers: John Marshall, Executive Vice President, 1012 14th St., N.W., Washington, D.C.

National Canners Association: G. E. STeene, Assistant to the Executive Vice President, 1133 20th St., N.W., Washington, D.C.

National Fisheries Institute: H. W. MAGNusson, Technology Director, 1614 20th St., N. W., Washington, D.C.

National Tank Truck Carriers, Inc.: Lours Reznek, Director of Engineering and Safety, 1616 P St., N.W., Washington, D.C.

Paper Cup and Container Institute, Inc.: R. W. Foster, Assistant to Executive Director, 250 Park Ave., New York, N.Y.

Paper, Stationery, and Tablet Manufacturing Association, Inc.:

E. P. Eaton, Executive Secretary, 444 Madison Ave., Suite 2102, New Iork, N.Y.

R. L. Bullington.

F. MI. McIntosh, Southern Central Co., 7365 Dudly, Memphis, Tenn.

Phillips Petroleum Co.: A. F. DYER, Technical Representative, Bartlesville, Okla.

Pillsbury Co.: C. E. Joyce, General Claim Manager, 608 Second Ave., S., Minneapolis, Minn.

Procter \& Gamble Co.:

J. H. Chaloud, Associate Director, Product Development Division, Ivorydale Technical Center, Cincinnati, Ohio.

D. R. Byerly, Assistant Director, Research and Development.

H. B. Stevenson.

J. C. Ervin.

Pyrofax Gas Corporation: W. H. Scott, Service Manager, 295 Madison Ave., New York, N.Y.

Quaker Oats Co.: F. A. Doвsins, Quality Control Manager, Chicago, Ill.

Republic Steel Corp.: D. R. SmITH, Corporation Weighing Supervisor, 410 Oberlin Rd., S.W., Massillon, Ohio. 
Sayrolt, J. W., Business Counselor on Weights and Neasures Laws, 9209 Carlyle Ave., Surfsicle, Miami Beach, Fla.

Scale Journal Publishing Co.: J. K. Prekeld, Editor, 176 W. Adams Street, Chicago 3, Ill.

Scale Manufacturers Association: Arthur Sanders, Secretary, One Thomas Circle, Washington, D.C.

Sun Oil Co.:

E. IV. Hess, Manager, General Marketing Operations, 1608 Walnut St., Philadelphia, $\mathrm{Pa}$

IV. A. Pierson, Special Assistant.

Swift \& Co.: F. G. SPIker, Head, Washington, D.C. Law Department, 711 14th St., N.W., Washington, D.C.

Thread Institute, Inc.: W. F. Operer, Executive Director, 15 E. 40th St., New York, N.Yr.

Tissue Association: C. J. Carey, Executive Secretary, 122 E. 42nd St., New Tork, N.Y.

Visking Co., Division of Union Carbide Corp.: W. M. SAwers, Manager, Special Services, 800 Wyatt Bldg., Washington, D.C.

Western Weighing and Inspection Bureau: C. G. Jonnson, Supervisor, Weight Agreements and Weighing, Room 460 Union Station, 517 W. Adams St., Chicago, Ill.

\section{Guests}

Blickley, J. F., 4538 North Carlisle St., Philadelphia, Pa.

Caulfield, M. J., Westiville Rd., Amonesson, N.J.

Lirio, Alfred, P.O. Box 369 , Vineland, N.J.

McBride, J. P., 3 Livermore Rd., Belmont, Mass.

Phillips, C. S., Chief, Weights and Measures Division, Standards Branch, Department of Trade and Commerce, Ottarva, Canada.

Powers, J. J., 1347 Jerome St., Philadelphia, Pa.

RonerTs, J. R.. Chief Inspector of Weights and Measures and Secretary, The Institute of Weights and Measures Administration England, 57 a Newton St., Piccadilly, Manchester, England. 


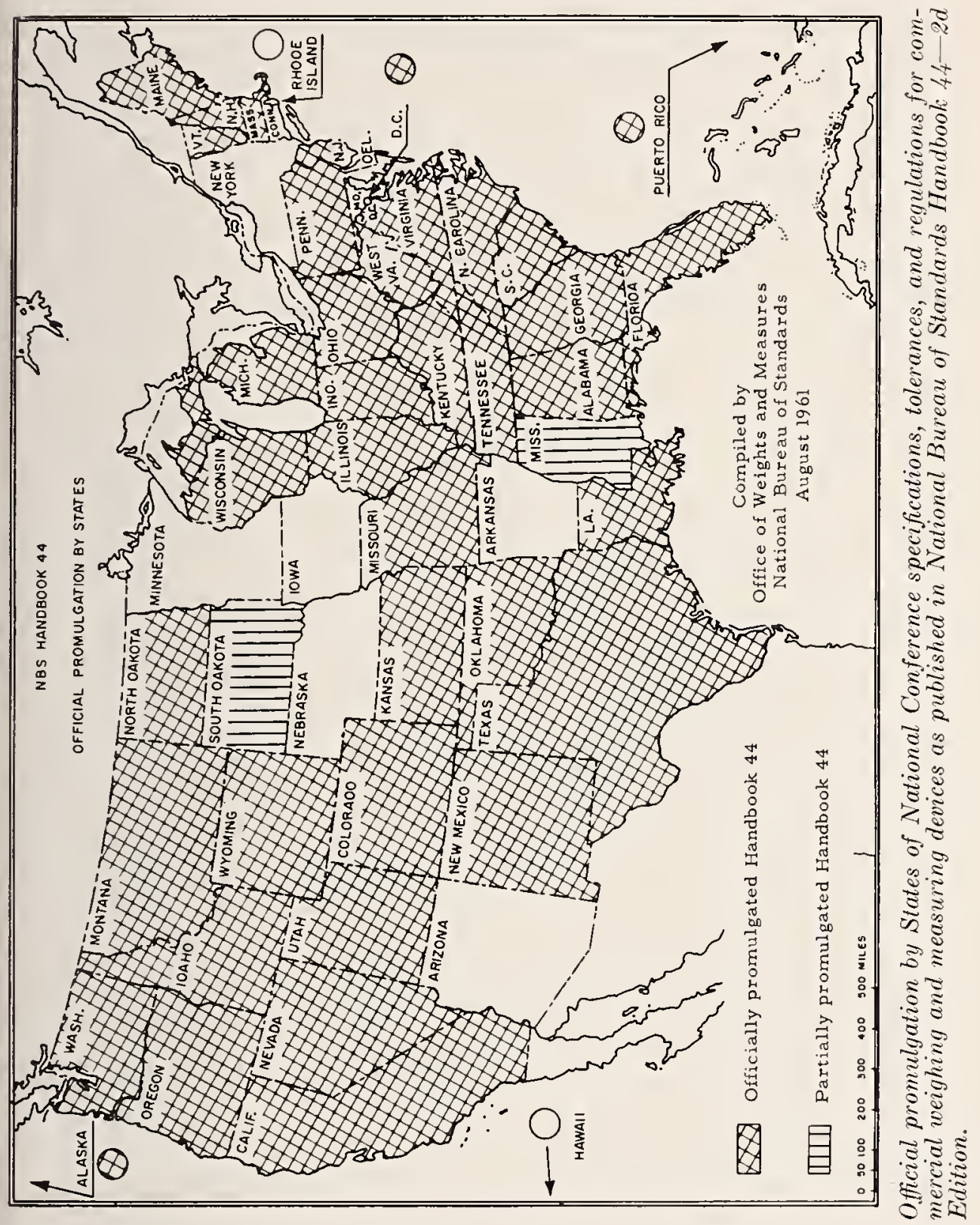




\section{THE NATIONAL, BUREAU OF STANDARDS}

The scope of activities of the National Bureau of Standards at its major laboratories in Washington, D.C., and Boulder, Colo., is suggested in the following listing of the divisions and sections engaged in technical work. In general, each section carries out specialized research, development, and engineering in the field indicated by its title. A bricf description of the activities, and of the resultant publications, appears on the inside of the front corer.

\section{WASHINGTON, D.C.}

Electrieity. Resistance and Reactance. Electrochemistry. Electrical Instruments. Magnetic Measurements. Dielectries.

Metrology. Photometry and Colorimetry. Refractometry. Photographic Research. Length. Engineering Metrology. Mass and Scale. Volumetry and Densimetry.

Heat. Temperature Physics. Heat Measurements. Cryogenic Physics. Equation of State. Statistical Physics.

Radiation Physies. K-ray. Radioactivity. Radiation Theory. High Energy Radiation. Radiological Equipment. Nucleonic Instrumentation. Neutron Physies.

Analytieal and Inorganie Chemistry. Pure Substances. Spectrochemistry. Solution Chemistry. Standard Reference Materials. Applied Analytical Research.

Mechanies. Sound. Pressure and Vacuum. Fluid Mechanies. Engineering Mechanies. Rheology. Combustion Controls.

Organic and Fibrous Materials. Rubber. Textiles. Paper. Leather. Testing and Specifications. Polymer Structure. Plasties. Dental Research.

Metallurgy. Thermal Metallurgy. Chemical Metallurgy. Mechanical Metallurgy. Corrosion. Metal Physics. Electrolysis and Metal Deposition.

Mineral Products. Engineering Ceranies. Glass. Refractories. Enameled Metals. Crystal Growth. Physical P'operties. Constitution and Microstructure. Building Researeh. Structural Engineering. Fire Research. Mechanical Systems. Organic Building Materials. Codes and Safety Standards. Heat Transfer. lnorganic Building Materials.

Applied Mathematies. Numerical Analysis. Computation. Statistical Engineering. Mathematical Physics. Operations Research.

Data Proeessing Systems. Components and Techniques. Digital Circuitry. Digital Systems. Analog Systens. Applications Engineering.

Atomic Physies. Spectroscopy. Infrared Spectroscopy. Solid State Physies. Electron Physies. Atomic Physies.

Instrumentation. Engineering Electronies. Electron Devices. Electronic Instrumentation. Mechanical Instruments. Basic Instrumentation.

Physieal Chemistry. Thermochemistry. Surface Chemistry. Organic Chemistry. Molecular Spectroscopy. Molecular Kineties. Mass Spectrometry.

Oflice of Weights and Measures 


\section{BOULDER, COLORADO}

Cryogenic Engineering. Cryogenic Equipment. Cryogenic Processes. Properties of Materials. Gas Liquefaction.

Radio Propagation Physics. Low Frequency and Very Low Frequency Research. Ionosphere Research. Prediction Services. Sun-Earth Relationships. Field Engineering. Radio Warning Services.

Radio Propagation Engineering. Data Reduction Instrumentation. Radio Noise. Tropospheric Measurements. Tropospheric Analysis. Propagation-Terrain Effects. Radio-Meteorology. Lower Atmospheric Physies.

Radio Standards. High-Frequency Electrical Standards. Radio Broadcast Service. Radio and Microwave Materials. Electronic Calibration Center. Millimeter-Wave Research. Microwave Circuit Standards.

Radio Communication and Systems. High Frequency and Very High Frequency Research. Modulation Research. Antenna Research. Navigation Systems. Space Telecommunications.

Upper Atmosphere and Space Physics. Upper Atmosphere and Plasma Physics. Ionosphere and Exosphere Scatter. Airglow and Aurora. Ionospheric Radio Astronomy. 
